UNIVERSIDADE DE SÃO PAULO

ESCOLA DE ARTES, CIÊNCIAS E HUMANIDADES

PROGRAMA DE PÓS-GRADUAÇÃO EM TÊXTIL E MODA

LUCIANA IWAMOTO

A influência japonesa nas artes e na moda europeia da virada do século XX

São Paulo

2016 


\section{A influência japonesa nas artes e na moda europeia da virada do século XX}

Dissertação apresentada à Escola de Artes, Ciências e Humanidades da Universidade de São Paulo para obtenção do título de Mestre em Ciências do Programa de Pós-Graduação em Têxtil e Moda.

Versão corrigida contendo as alterações solicitadas pela comissão julgadora em 27 de junho de 2016. A versão original encontra-se em acervo reservado na Biblioteca da EACH/USP e na Biblioteca Digital de Teses e dissertações da USP (BDTD), de acordo com a Resolução CoPGr 6018, de 13 de outubro de 2011.

Área de concentração: Programa de PósGraduação em Têxtil e Moda

Linha de Pesquisa: Projeto de Têxtil e Moda

Orientadora: Prof.a Dr. a Maria Sílvia Barros de Held 
Autorizo a reprodução e divulgação total ou parcial deste trabalho, por qualquer meio convencional ou eletrônico, para fins de estudo e pesquisa, desde que citada a fonte.

CATALOGAÇÃO-NA-PUBLICAÇÃO

(Universidade de São Paulo. Escola de Artes, Ciências e Humanidades. Biblioteca)

Iwamoto, Luciana

A influência japonesa nas artes e na moda europeia da virada do século XX / Luciana Iwamoto ; orientadora, Maria Silvia Barros de Held.

- São Paulo, 2016

205 f. : il

Dissertação (Mestrado em Ciências) - Programa de Pós-

Graduação em Têxtil e Moda, Escola de Artes, Ciências e

Humanidades, Universidade de São Paulo

Versão corrigida

1. Moda - Europa - Século XIX - Influência japonesa. 2. Moda

- Europa - Século XX - Influência japonesa. 3. Artes - Europa -

Século XIX - Influência japonesa. 4. Artes - Europa - Século XX Influência japonesa. 5. Moda - Design. I. Held, Maria Silvia Barros de, orient. II. Título.

CDD 22.ed. - 391.00940956 


\section{Nome: LUCIANA IWAMOTO}

Título: A influência japonesa nas artes e na moda europeia da virada do século XX

Dissertação apresentada à Escola de Artes, Ciências e Humanidades da Universidade de São Paulo para obtenção do título de Mestre em Ciências do Programa de Pós-Graduação em Têxtil e Moda.

Área de concentração: Programa de PósGraduação em Têxtil e Moda

Aprovada em: 27/06/2016

\section{Banca examinadora}

Prof. a Dr. a Maria Sílvia Barros de Held

Instituição: EACH - Universidade de São Paulo

Julgamento:

Assinatura:

Prof.a Dr. a Alexandra Cruchinho

Instituição: ESART - Instituto Politécnico de Castelo Branco.

Julgamento: Assinatura:

Prof. - Dr. a : Isabel Cristina Italiano

Instituição: EACH - Universidade de São Paulo

Julgamento:

Assinatura:

Prof. Dr. Fausto Viana

Instituição: ECA - Universidade de São Paulo

Julgamento: Assinatura: 
Dedico este trabalho à minha família 


\section{AGRADECIMENTOS}

Agradeço primeiramente à Deus por me guiar, iluminar e dar força para seguir em frente com os meus objetivos e não desanimar com as dificuldades.

Aos meus pais, Emy e Paulo, que sempre primaram pela minha educação e pela confiança em mim depositada, meus sinceros agradecimentos.

Aos meus irmãos Juliana e Lui, à minha sobrinha Carol e ao meu tio Sérgio pelo apoio.

À minha orientadora e professora Dr. a Maria Sílvia Barros de Held, pela generosidade e alegria na orientação desse trabalho. Pela oportunidade, acolhimento e confiança depositada, meu muito obrigada.

Aos docentes da USP EACH e em especial ao professor Dr. Luís Cláudio Portugal do Nascimento, pela motivação contagiante.

À professora Dr. a Alexandra Cruchinho, à professora Dr. a Isabel Cristina Italiano e ao professor Dr. Fausto Viana, por se dedicarem às orientações em minha banca de qualificação.

Ao meu marido Renato e à sua família, pelo apoio e paciência.

Aos meus amigos e colegas, em especial à amiga que este mestrado me trouxe, Laura de Mello Mattos Anacleto, por ter me auxiliado incontáveis vezes, muito obrigada.

À Coordenação de Aperfeiçoamento de Pessoal de Nível Superior (CAPES) pelo suporte financeiro e interesse nesta pesquisa

E a todos aqueles que, direta ou indiretamente, contribuíram para a realização de mais esta etapa da minha vida. Espero retribuir e passar adiante toda a ajuda e apoio que me foi oferecido. 
A não ser que nos fortalecêssemos através da transfusão de sangue fresco, como poderemos manter nossa energia? E onde está a civilização - antiga ou moderna, próxima ou distante - que nunca emprestou, mesmo que um pouco, sua cultura artística?

BING, 1888, p. 5 


\section{RESUMO}

IWAMOTO, Luciana. A influência japonesa nas artes e no design de moda europeu da virada do século XX, 2016. 195 p. Dissertação (Mestrado em Ciências) - Escola de Artes, Ciências e Humanidades, Universidade de São Paulo, São Paulo, 2016. Versão corrigida.

Esta pesquisa tem como objetivo analisar o período compreendido entre a metade do século XIX e o começo do século XX a fim de identificar que aspectos e componentes da estética e valores culturais japoneses teriam sido eventualmente integrados aos movimentos artísticos europeus e ao design de moda. O interesse ocidental pelo Oriente sempre existiu, porém, foi intensificado após a abertura dos portos japoneses em 1854, depois de mais de dois séculos em reclusão. $O$ encontro entre duas culturas tão distintas causou grande entusiasmo na Europa, com diversos autores que defendem que esta aproximação influenciou o rumo das artes, do design e de outros diversos campos, resultando em um movimento estético denominado Japonismo. Desse modo, esta pesquisa de natureza qualitativa, na modalidade histórica, gerada a partir de estudos bibliográficos e estudo de campo em museus e exposições, pretende expor exemplos e tecer reflexões sobre a importância do intercâmbio cultural entre o Japão e a Europa do final do século XIX e início do século XX, mais especificamente nos campos da arte e da moda.

Palavras-chave: design de moda da virada do século $X X$, arte ocidental e Japão, influência oriental, japonismo, virada do século XX 


\begin{abstract}
IWAMOTO, Luciana. The Japanese influence on European Arts and Fashion Design at the turn of 20th Century, 2015. 195 p. Thesis (Master of Science) - School of Arts, Sciences and Humanities, University of São Paulo, São Paulo, 2016. Reviewed version.

The aim of this research is to study the period between mid-19th century and beginning of 20th century to identify which aesthetic and cultural values aspects and components would eventually have been integrated to European fashion design and art movements. The occidental interest towards the orient have always existed, although, it was intensified after the opening of Japanese ports on 1854, after more than two centuries of seclusion. The encounter of such different cultures triggered enthusiasm in Europe, and several authors suggest that this gathering led the way of art, design and many several fields, resulting in an aesthetic movement called Japonism. Therefore, this qualitative research, on history, generated from bibliographical and field study in museums and exhibits, intends to bring into thought the importance of cultural exchange between Japan and Europe on the end of 19th Century and beginning of 20th century, specifically on art and fashion.
\end{abstract}

Keywords: fashion design at the turn of 20th century, western art and Japan, oriental influence, japonisme, turn of 20th century 


\section{LISTA DE FIGURAS}

Figura 1 - Biombo do artista oficial Kitagawa Sôsetsu. Período Edo

Figura 2 - Início do ukiyo-e. Duas mulheres e um homem no portão. Parte integrante de um livro. Hishikawa Moronobu, século XVII

Figura 3 - Contemplação de árvores de cerejeira. Xilogravura com cor aplicada à mão. Hishikawa Moronobu, século XVII

Figura 4 - O jardim de ameixa em Kameido. Da série Cem famosas vistas de Edo. Utagawa Hiroshige, 1857

Figura 5 - Duas mulheres com leque ao lado de um córrego. Da série As seis elegantes do Rio Tama, c. 1802 34

Figura 6 - Amantes no andar de cima da casa de chá. Kitagawa Utamaro, 1799 35

Figura 7 - A Grande Onda de Kanagawa. Katsushika Hokusai, entre 1830 e 1832 .... 37

Figura 8 - Exposição dedicada a Hokusai. Grand Palais, Paris, 2014 38

Figura 9 - Pavilhão japonês. Exposição Internacional de Londres, 1862 .45

Figura 10 - Objetos japoneses expostos na Exposição Internacional de Paris de 1867 46

Figura 11 - L'art Japonais, 1886 51

Figura 12 - Bing (à esquerda) em cerimônia do chá 52

Figura 13 - Edição 14 da publicação Le Japon Artistique 53

Figura 14 - Versões alemã e inglesa da publicação Le Japon Artistique 53

Figura 15 - Exposição de Gravuras Japonesas 54

Figura 16 - As Respigadoras. Jean François Millet, 1857 59

Figura 17 - A japonesa ao banho. James Tissot, 1864 63

Figura 18 - Jovens observando objetos japoneses. James Tissot, 1869 .63

Figura 19 -O Biombo Dourado. James Whistler, 1864 64

Figura 20 - Imagens comparativas: Detalhe da xilogravura da série 36 visões do Monte Fuji, Katsushika Hokusai e A Sacada, James Whistler, 1870

Figura 21 - Noturno em Azul e Ouro: A velha ponte de Battersea. James Whistler, entre 1872 e 1875 65

Figura 22 - Ponte Kyōbashi. Utagawa Hiroshige, c. 1857. 66

Figura 23 - La Japonaise. Claude Monet, 1876. 67

Figura 24 - Retrato de Émile Zola. Édouard Manet, 1868 68

Figura 25 - Fuguku hyakkei da série Cem Visões do Monte Fuji. Katsushika Hokusai 69

Figura 26 - A Torre em Construção, como visto do Trocadéro da série Trinta e seis visões da Torre Eiffel. Henri Rivière, 1902

Figura 27 - Retrato de Père Tanguy (com ukiyo-e ao fundo). Vincent van Gogh, 1887 .71 
Figura 28 - Imagens comparativas: Chuva repentina sobre a ponte Shin-Ōhashi e Atake, Utagawa Hiroshige, 1855 e Ponte sob a chuva - após Hiroshige, Vincent van Gogh, 1887 ...72

Figura 29 - Autorretrato dedicado a Paul Gauguin. Vincent van Gogh, 1888. 73

Figura 30 - Claude Monet em Giverny em sua sala de jantar decorada com gravuras ukiyo-e 74

Figura 31 - Detalhe da casa de Claude Monet em Giverny, decorada com estampas ukiyo-e

Figura 32 - Comparação: Xilogravura de Utagawa Hiroshige, 1856 e Ponte Japonesa em Giverny, Claude Monet, 1889 .75

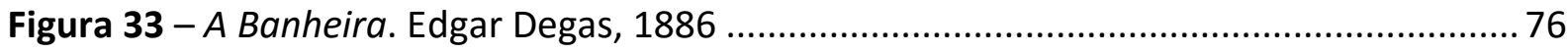

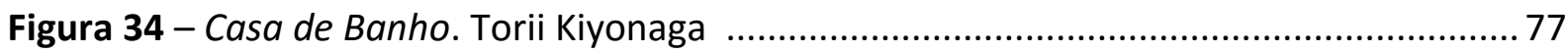

Figura 35 - Imagens comparativas: xilogravura Mulher Penteando os Cabelos da série Dez Estudos Fisionômico da Mulher. Kitagawa Utamaro, c. 1802 e estudo de Edgar Degas, 1889

Figura 36 - Imagens comparativas: xilogravura de Kitagawa Utamaro, período Edo e Mulher tendo seu cabelo escovado, Edgar Degas, 1895

Figura 37 - Imagens Comparativas: xilogravura de Kitagawa Utamaro, 1803 e O banho da criança. Mary Cassatt, 1893

Figura 38 - Imagens comparativas: A Cortesã Hinazuru. Kitagawa Utamaro, 1794 e A Carta,

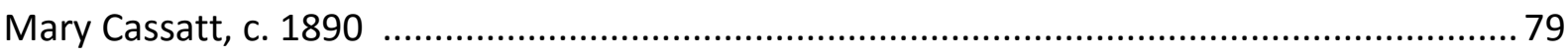

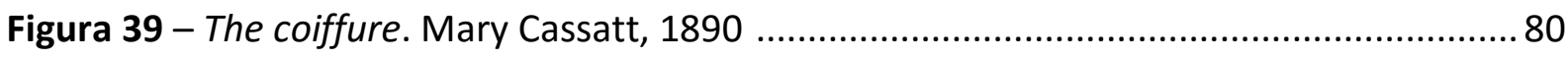

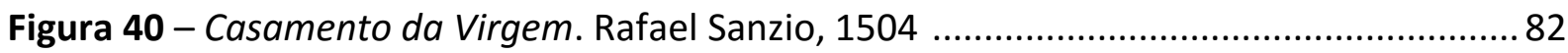

Figura 41 - O Martírio de São Sebastião. Antonio e Piero del Pollaiuolo, 1475 ...................... 83

Figura 42 - Impressão: Sol Nascente. Claude Monet, c. 1875 ............................................. 84

Figura 43 - Xilogravuras verticais de Suzuki Harunobu e Uchimasa. Período Edo ................. 85

Figura 44 - Composição assimétrica de Utagawa Hiroshige .................................................. 86

Figura 45 - Assimetria em O Tâmisa abaixo de Westminster. Claude Monet, c. 1871 ..........87

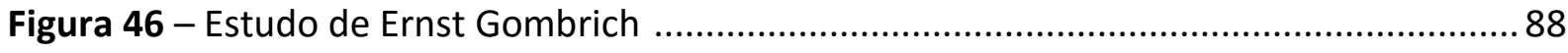

Figura 47 - Mulher no barco colhendo flores de lótus. Harunobu, 1765 ............................... 90

Figura 48 - Passeio de Barco. Édouard Manet, 1874 ........................................................... 90

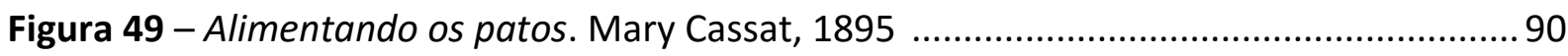

Figura 50 - O Barco no Epte. Claude Monet, 1890 ............................................................ 91

Figura 51 - Pôster Jane Avril. Henri de Toulouse Lautrec, 1893 ........................................... 92

Figura 52 - Pôster Le Divan Japonais. Henri de Toulouse Lautrec, 1892 .............................. 92

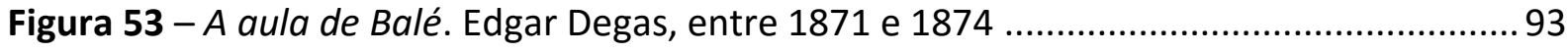

Figura 54 - Estação de Otsu, da série Cinquenta e três estações de Tokaido. Utagawa Hiroshige, c. 1848 


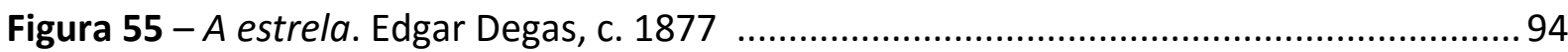

Figura 56 - Dançarinas subindo uma escada. Edgar Degas, 1886 ......................................... 95

Figura 57 - Imagens comparativas: Banho na água gelada. Kitagawa Utamaro, 1799 e Banho

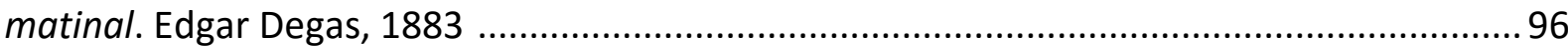

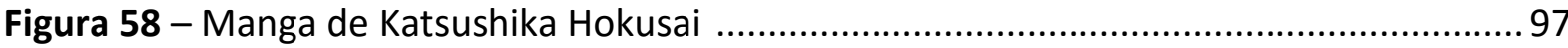

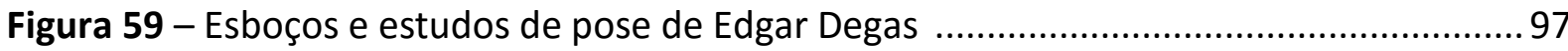

Figura 60 - Imagens Comparativas: esboço de Edgar Degas, 1879 e detalhe do manga de

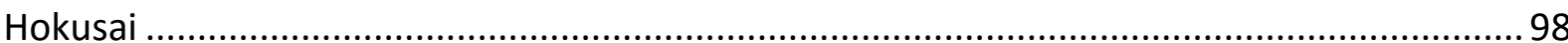

Figura 61 - Quarto em Artes. Vincent van Gogh, 1888 ...................................................... 100

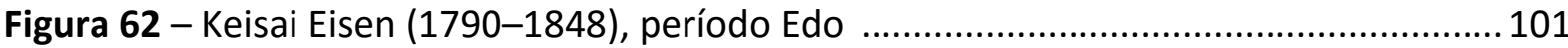

Figura 63 - Kitagawa Utamaro Furyu Nana Komachi. Período Edo ....................................102

Figura 64 - La Mousmé. Vincent van Gogh, 1888 ...........................................................103

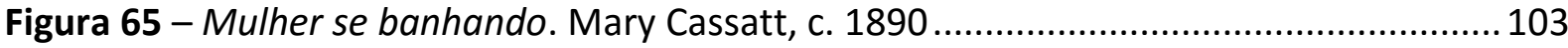

Figura 66 - Mulher com Cachorro. Pierre Bonnard, 1891 ................................................ 105

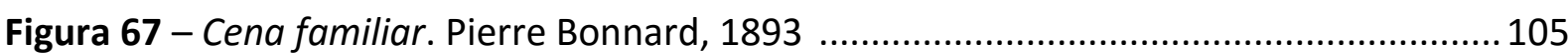

Figura 68 - Mulher no Jardim. Pierre Bonnard, entre 1892 e 1899 ................................... 106

Figura 69 - Misia and Vallotton at Villeneuve. Édouard Vuillard 1899 ............................... 107

Figura 70 - Mulher Cerzindo. Édouard Vuillard, c. 1891 ................................................... 107

Figura 71 - Caminho de Mudança, L'Estaque. André Derain, 1906.................................... 108

Figura 72 - O Retrato de Adele Bloch-Bauer. Gustav Klimt, 1905 ......................................109

Figura 73 - Avenida de Clichy. Louis Anquetin, 1887 ......................................................110

Figura 74 - Mulheres bretãs no prado. Émile Bernard, 1888 .............................................. 111

Figura 75 - Alteração do corpo provocado pelo espartilho................................................113

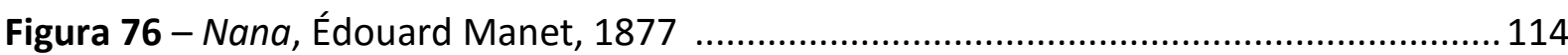

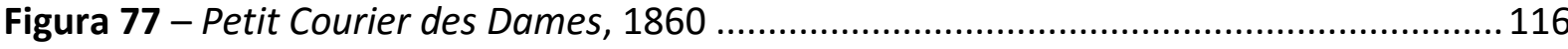

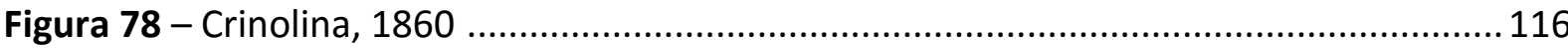

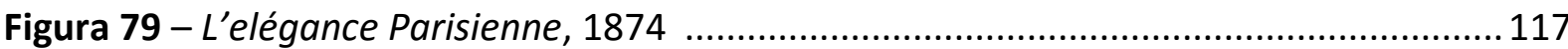

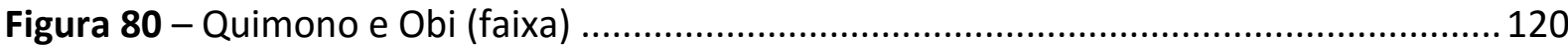

Figura 81 - A Sacada, 1867-1870 e A Princesa da Terra das Porcelanas, 1864. James McNeill

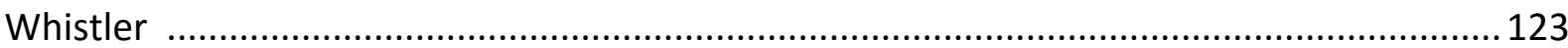

Figura 82 - La Parisienne Japonais. Alfred Stevens, c. 1872 ............................................121

Figura 83 - Madame Hériot. Pierre Auguste Renoir, 1882 ..............................................122

Figura 84 - Sada Yacco na capa da revista Le Théatre, 1900 ..............................................124

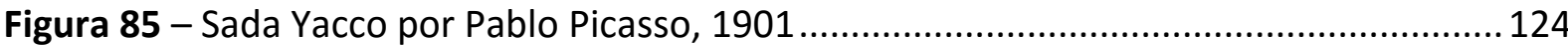

Figura 86 - Anúncio Quimono Sada Yacco, 1905 .............................................................. 125 
Figura 87 - Anúncio Quimono Sada Yacco, 1905 126

Figura 88 - Anúncios de quimono de Babani, início do século XX ....................................126

Figura 89 - Quimono de Babani, início do século XX ......................................................... 127

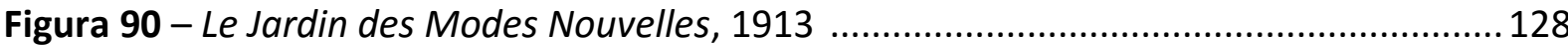

Figura 91 - Quimonos adaptados ao mercado ocidental, Takashimaya Co, 1900 ...............129

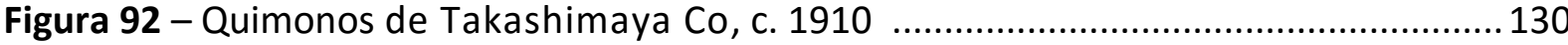

Figura 93 - Robe de Chambre criado para o mercado Europeu. Tashimaya Co., c. 1906 ....130

Figura 94 - Vestido construído a partir de um quimono. Turner, c. 1870 ...........................132

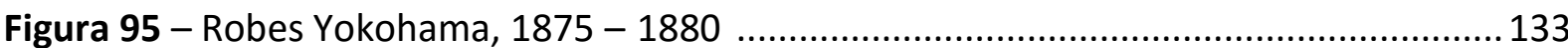

Figura 96 - Vestidos japoneses para o mercado europeu, 1896 - 1898 ............................133

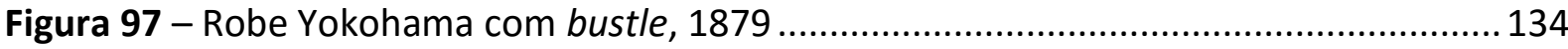

Figura 98 - Tecido de Eugène Prelle, Lyon, século XIX ….................................................. 135

Figura 99 - Tecido adamascado de Eugène Prelle, Lyon, 1877 ........................................135

Figura 100 - Impressão em rolo de lona de algodão, Alsácia, 1890 ...................................136

Figura 101 - Impressão de bloco em lona de algodão, Alsácia, 1889 .................................137

Figura 102 - Amostra de móveis. Rolo de impressão sobre tela de algodão, 1870 .............137

Figura 103 - À esquerda, Papillons et Feiulles de Mauve, 1907, Bianchini Férier et Cie. À direita,

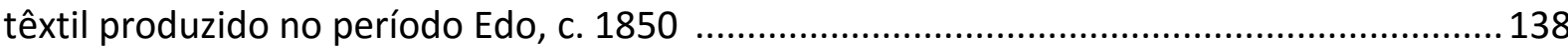

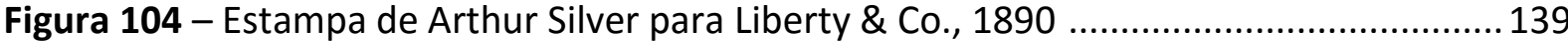

Figura 105 - Japão: sua arquitetura, arte e manufatura. Christopher Dresser, 1882 ..........140

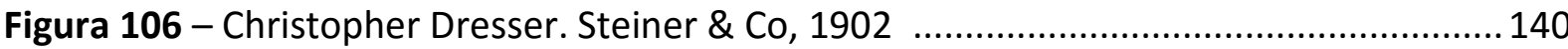

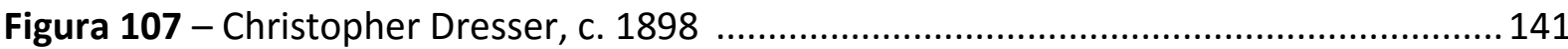

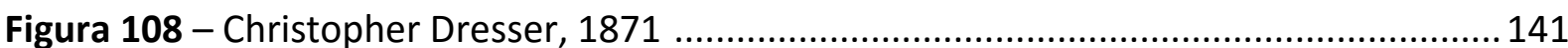

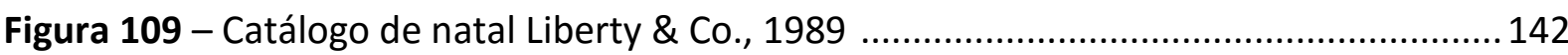

Figura 110 - Vestidos de Jacques Doucet, final do século XIX .........................................142

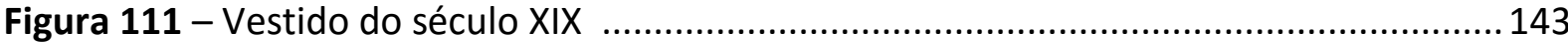

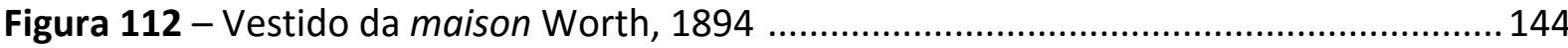

Figura 113 - Gravura Borboleta e Libélula. Kitagawa Utamaro, 1788 ................................145

Figura 114 - Vestido da maison Worth, 1898 ...................................................................... 145

Figura 115 - Capacete Hoshi Kabuto ................................................................................ 146

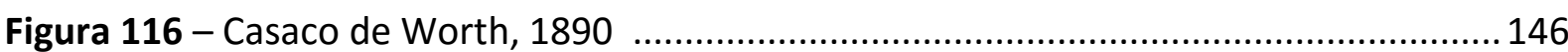

Figura 117 - Capa de McQueen para Givenchy, Paris, 1996 ............................................147

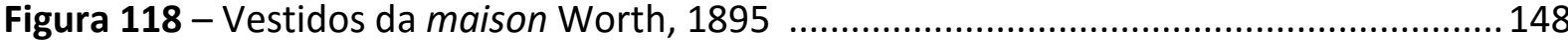

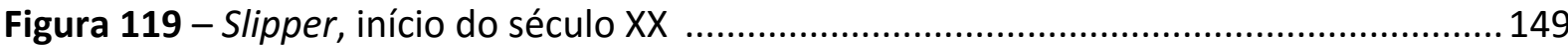


Figura 120 - Bolsa, início do século XX 149

Figura 121 - Botões Satsuma 150

Figura 122 - Jovem com um guarda-sol japonês. Pierre Auguste Renoir, 1876 151

Figura 123 - Mrs. Newton com um guarda-sol. James Tissot, c. 1879 152

Figura 124 - Ilustração de La Vie Parisienne: "Os guarda-sóis da moda: Japonaiserie de outono". Início do século XX 153

Figura 125 - Leques japoneses desenvolvidos para exportação. Final do século XIX 154

Figura 126 - Garota com leque. Auguste Renoir, c. 1881 155

Figura 127 - Japonisme. Ilustraçao de Henry Somm para Monde Parisien. 17 de abril de 1879

Figura 128 - Mulher com leques. Édouard Manet, 1873

Figura 129 - Duas irmãs no sofá. Berthe Morisot, 1869 157

Figura 130 - Leques pintados por Edgar Degas, 1879 157

Figura 131 - Les Poseuses. Georges Seurat, 1886-1888 158

Figura 132 - Casaco quimono. Paul Poiret, 1903 161

Figura 133 - Casaco por Paul Poiret, c. 1912 162

Figura 134 - Casaco por Paul Poiret, 1910 163

Figura 135 - Evening Coat, Paul Poiret, c. 1912 164

Figura 136 - Evening Coat, Paul Poiret, 1912 165

Figura 137 - Manteau. Paul Poiret, 1913 165

Figura 138 - Casaco La Perse, 1911 166

Figura 139 - Casacos quimono representados no álbum Les Robes de Paul Poiret, ilustrado por Paul Iribe, 1908 168

Figura 140 - Opera Coat no álbum Les Choses de Paul Poiret, ilustrado por Georges Lepape, 1911 168

Figura 141 - Capas da Revista Vogue, 1917 e 1920 169

Figura 142 - Manteau D’Auto, casaco usado por Denise Poiret. Paul Poiret, 1912 170

Figura 143 - Vestido em estrutura em "T" usado por Denise Poiret. Paul Poiret, 1912 .......171

Figura 144 - Fotografia de Henri Manuel, modelos vestindo a coleção de Poiret, 1910 .....172

Figura 145 - Gravuras japonesas penduradas no ateliê de Vionnet 173

Figura 146 - Adaptação da manga do quimono para o vestuário ocidental 174

Figura 147 - Vestido para a duquesa de Gramont. Madeleine Vionnet, Revista Vogue, 1922 176

Figura 148 - Vestidos inspirados no quimono, 1922. Madeleine Vionnet. Ilustração de Lisa Feuerherm 
Figura 149 - Vestido de Vionnet confeccionado apenas com quadrados de tecido, 1919 ..178

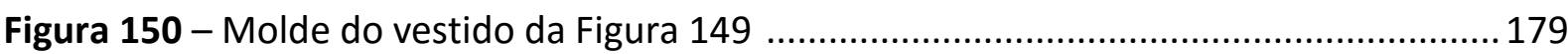

Figura 151 - Vestido de base retangular. Madeleine Vionnet, 1921 .................................. 180

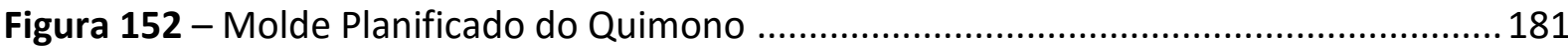

Figura 153 - Molde Planificado de blusa ocidental ......................................................... 181

Figura 154 - Molde do vestido de base retangular (Figura 151). Madeleine Vionnet, 1921182

Figura 155 - Japonika, Madeleine Vionnet, 1924. Ilustração de Thayaht ............................ 183

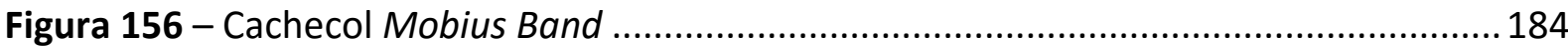

Figura 157 - Detalhe do vestido de Vionnet, 1918 - 1919 ................................................. 186

Figura 158 - Bordado com motivos de leque. Fotografia de Edward Steichen, Revista Vogue, 1925 186

Figura 159 - Imagens comparativas: seigaiha tradicional e vestido de Vionnet 187

Figura 160 - Vestido Henriette. Madeleine Vionnet, 1923 ............................................. 188

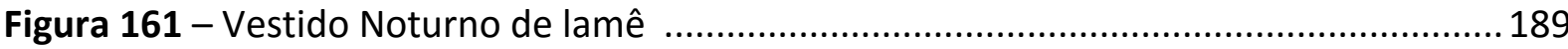

Figura 162 - Day Dress. Madeleine Vionnet, 1925 ............................................................... 190 


\section{SUMÁRIO}

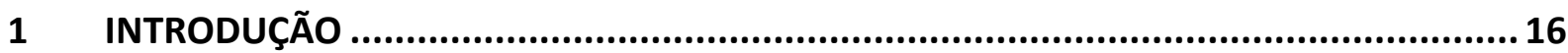

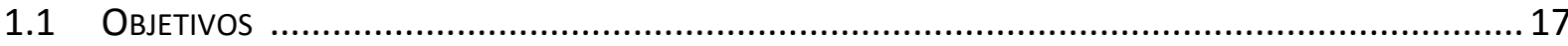

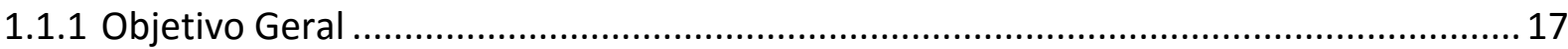

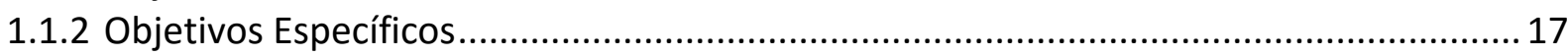

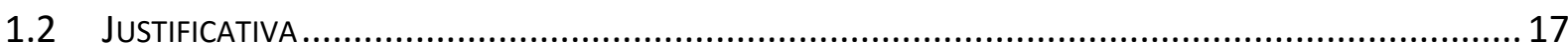

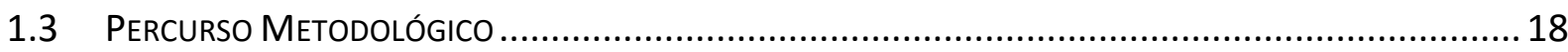

2 O CONTEXTO JAPONÊS - O FLORESCIMENTO E A IDENTIDADE DA ARTE JAPONESA.. 19

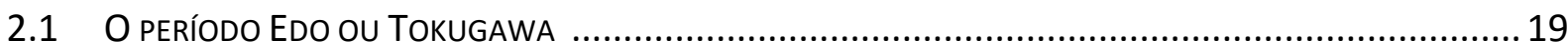

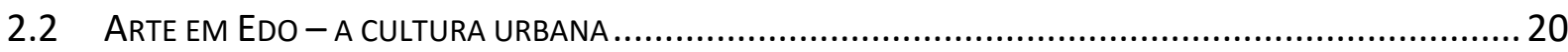

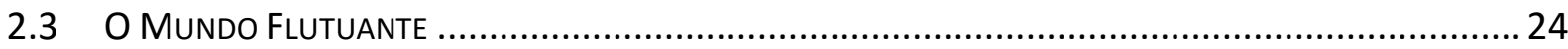

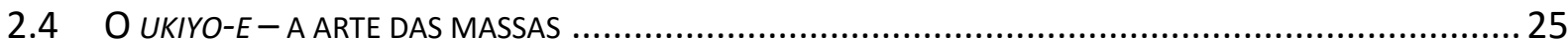

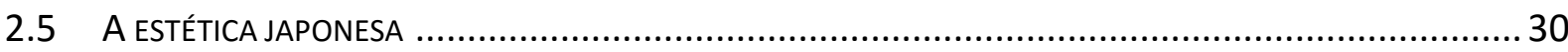

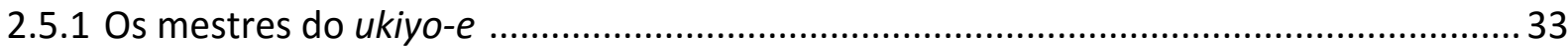

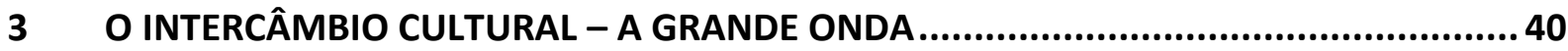

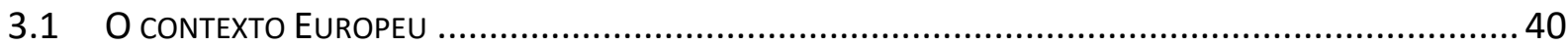

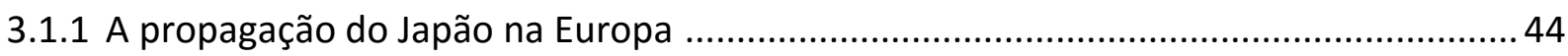

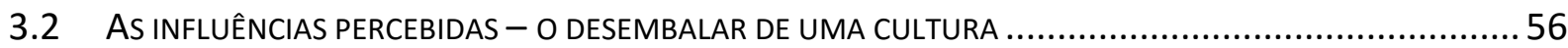

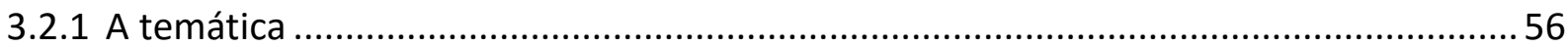

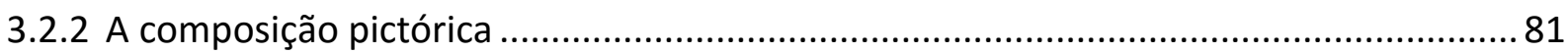

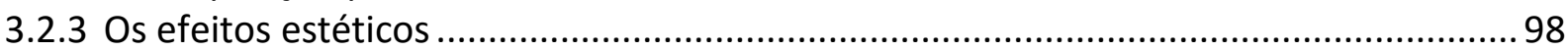

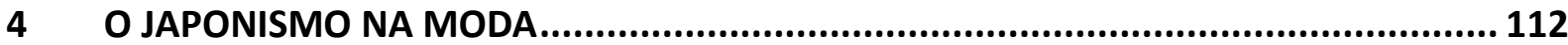

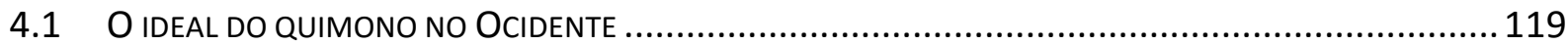

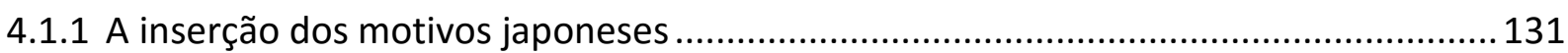

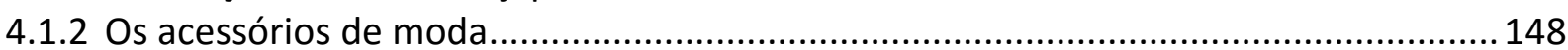

4.2 Transição do séCUlo XX: Paul Poiret e Madeleine Vionnet ......................................... 159

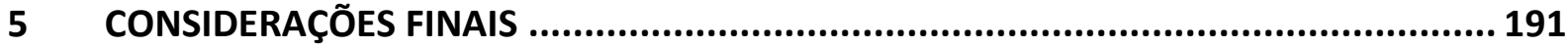

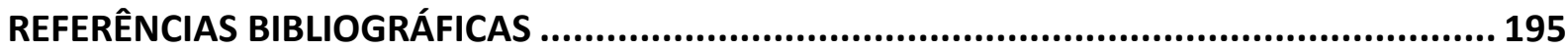




\section{INTRODUÇÃO}

De acordo com Knox (2011, p.141), a cultura japonesa exerceu maior influência sobre a Europa em relação a qualquer outra nação. Diferentemente das outras formas de orientalismo, o Japão não se infiltrou gentilmente, mas surgiu como tsunami estético e cultural que se alastrou de maneira multiforme em vários campos, longe de se estabelecer como superficial. Segundo vários estudiosos, teria alcançado de forma decisiva a estética de todo o século XIX e XX, sendo determinante no direcionamento da arte e do design de moda moderno (LAMBOURNE, 2005).

Com a hipótese de que, portanto, a influência japonesa na Europa se deu de forma direta e indireta, este trabalho busca investigar tal fenômeno, mediante, predominantemente, as gravuras ukiyo-e e o quimono na Europa - principalmente na França, local que melhor acolheu essa tendência - com foco nos movimentos artísticos e no design de moda. Nesse sentido, pretende-se expor a importância da fertilização cruzada e do intercâmbio cultural e como tais ligações possibilitaram a criar de novos elementos estéticos e compositivos, buscando respeitar a cronologia dos fatos.

No segundo capítulo, que corresponde ao item 2, aborda-se a realidade japonesa no contexto do Período Edo. Mais do que focar apenas e imediatamente o discurso estético, que pode levar facilmente a equívocos, este trabalho reconhece e analisa as considerações políticas e econômicas que motivaram esse intercâmbio cultural.

No terceiro e quarto capítulos, observa-se o fenômeno.

O terceiro capítulo, correspondente ao item 3, expõe o resultado desse intercâmbio cultural na produção de pintores impressionistas e outros artistas. O objetivo desse capítulo não é tratar de cada pintor separadamente e, sim, analisar vários aspectos estéticos específicos que serão considerados e ilustrados com exemplos extraídos em suas obras. Três vertentes serão abordadas: a temática, a composição e os efeitos estéticos. Isso porque, mediante estudo bibliográfico, percebeu-se que eram os mais relevantes.

No quarto capítulo, ou seja, o item 4, aborda-se a influência que se repercute no âmbito do vestuário feminino, incluindo os acessórios de moda e a transição para o século XX, 
o qual se firmará com mais profundidade pela investigação histórica e análise de trabalho de designers revolucionários específicos; quais sejam: Paul Poiret e Madeleine Vionnet.

As considerações finais apontam os resultados que a pesquisa alcançou, incluindo as modificações, penetrações/inserções que o evento do Japonismo trouxe, destacando as possíveis contribuições desse estudo para a história da arte e do design do vestuário ocidental.

\subsection{OBjetIVOS}

\subsubsection{OBJETIVo Geral}

Analisar quais aspectos estéticos e culturais japoneses teriam sido absorvidos na arte e na moda europeia da metade do século XIX até o início do século XX.

\subsubsection{Objetivos Específicos}

- estudar os aspectos e componentes da estética japonesa

- realizar revisão bibliográfica sobre a influência da cultura japonesa na moda e arte europeia

- identificar quais são os aspectos estéticos japoneses que teriam sido transplantados para a Europa do século XIX

- exemplificar com trabalhos de designers e artistas relevantes, como a cultura oriental influenciou a moda e os movimentos artísticos

- analisar as características estéticas e de linguagem dos aspectos anteriormente identificados

\subsection{JUSTIFICATIVA}

A presente pesquisa se desdobra no exato período de revolução tanto da arte como da moda europeia, de modo que a dinâmica do processo de fertilização cruzada entre culturas tão diversas e entre formas de expressão estéticas também distintas foi expressiva, sendo 
determinante para o direcionamento da arte e do design de moda moderno, segundo Lambourne (2005). Desse modo, este estudo poderá contribuir para a discussão e maior compreensão no estudo da arte e principalmente do design de moda, o qual é muito pouco abordado, além de expor a importância do intercâmbio cultural, tão presente atualmente, na criação de novos valores estéticos e em processos e mecanismos presentes no fenômeno estudado.

\subsection{Percurso Metodológico}

Essa pesquisa possui abordagem qualitativa, na modalidade histórica que, de acordo com Neill (2014) caracteriza-se por ser centrada na avaliação de dados relativos a ocorrências passadas, a fim de testar hipóteses sobre causas, efeitos ou tendências desses eventos que podem ajudar a explicar os acontecimentos posteriores e antecipar eventos futuros. Mesmo que em alguns momentos ocorressem a superposições dos fatos, procurou-se seguir uma cronologia linear para maior entendimento.

Segundo Bordieu (1989), as interpretações qualitativas são construídas não de forma absoluta e objetiva, que requer normas e métodos específicos de análise, mas como teias de relações estruturadas às quais os agentes sociais atribuem significados.

No decorrer da pesquisa, foram privilegiados todos os recursos, métodos e materiais empíricos que vieram a ser úteis para subsidiar a realização do estudo. A maior fonte de pesquisa foi de cunho bibliográfico, pesquisas em periódicos, revistas, exposições e verificações de sites que apresentem informações e reflexões pertinentes ao tema, que posteriormente foram analisados e interpretados. 


\section{O CONTEXTO JAPONÊS - O FLORESCIMENTO E A IDENTIDADE DA ARTE JAPONESA}

\subsection{O PERÍOdO EdO OU TOKUGAWA}

O Japão do Período Edo compreendeu os anos de 1615 a 1868. Foi governado pela linhagem Tokugawa em sistema de ditadura feudal, conhecido como xogunato. Uma vez com o poder unificado, o primeiro xogum, leyasu Tokugawa, tinha como prioridade pôr fim à situação vivenciada nas épocas precedentes. Com efeito, essas épocas foram marcadas por séculos de guerras internas entre os senhores feudais (daymio), chegando a seu ponto máximo de descentralização e desordem. Para isso, criam-se, ao longo de toda era Tokugawa, diversos formalismos e regras que provocaram profundo impacto na sociedade japonesa (GUTH, 1996).

Guth registra ainda que, a mais considerável imposição foi a instituição de uma política de isolamento nacional conhecida como sakoku (o país recluso) que se estenderia por mais de 250 anos. Nessas circunstâncias e em razão do receio da contínua expansão do cristianismo por missionários estrangeiros, esse regime impedia qualquer estrangeiro de entrar no país, assim como os japoneses eram proibidos de saírem, tendo como consequência a pena de morte. Apesar da rígida política, exceções foram feitas e deveram ser consideradas - ainda que estritamente controladas - para o comércio com a China e a Coreia. Além desses dois países, a Holanda, que não possuía interesse em promover religião, tinha permissão para o comércio realizado pelo porto de Dejima, uma pequena ilha artificial na enseada de Nagasaki, não sendo oficialmente solo japonês. Esse contato comercial era limitado e devia possuir prévia autorização do governo xogunal. Todos esses fatos aumentaram progressivamente a curiosidade em relação ao Japão sobre o mundo, criando uma aura de mistério sobre esse país.

Apesar da claustrofóbica situação, as guerras e conflitos internos cessaram, consequência fundamental para que o país se desenvolvesse em vários campos. Alguns autores denominam esse período como "empobrecedor" no que se refere ao campo artístico, outros afirmam, todavia, que esse intervalo de isolamento foi fundamental para consolidar a identidade nacional japonesa, que se tornou possível pela consciência de diferenciação entre o interno e o externo, que, conforme Santos (2011), influiu na formação do senso de unidade. 
De acordo com Simmons (1958), esse evento marcou a primeira séria interrupção das relações do Japão com a China, o qual, há mais de mil anos, havia sido a fonte de inspiração e mentora para os estudiosos e artistas japoneses.

Independentemente das divergentes opiniões, sabe-se que foi uma era caracterizada pela alta aproximação e integração com as artes e presenciou o florescimento de inúmeras formas de expressão cultural. Essa realidade só foi possível devido muito ao aparecimento dos grandes centros urbanos proporcionados por um longo período de paz e estabilidade política que, há muito, o Japão não presenciava. Em seus estudos, Guth (1998), afirma que a despreocupação com improváveis guerras fez com que a vida urbana ganhasse impulso, principalmente na cidade de Edo, hoje conhecida como Tóquio.

\subsection{ARTE EM EDO - A CULTURA URBANA}

O estabelecimento de Edo como sede administrativa e militar do xogunato em 1603, transformou, em um período de apenas pouco mais de um século, uma aldeia pantanosa em uma cidade maior do que Londres ou Paris na época. Esse vertiginoso crescimento fez com que Edo, em 1720, possuísse mais de um milhão de habitantes, tornando-se o grande centro de riqueza e de consumo ao gerar um extraordinário volume de atividade econômica e cultural. Devido à demanda, provocada por essas atividades, artistas, arquitetos, decoradores, ilustradores e pintores de todo Japão começaram a afluir para a capital (SEIJI, 2014).

De acordo com Breuer (1994), a rápida urbanização, estabilidade e riqueza da nova capital foram também catalisadas por outra política do xogunato conhecida como "residência alternada" (sankin-kōtai). Essa política, que sofreu alterações ao longo do domínio Tokugawa, consistia em uma imposição para que todos os grandes proprietários de terras se alternassem periodicamente entre suas províncias natais e Edo em determinado período de assistência e, ainda, quando retornassem às suas províncias, suas famílias deveriam permanecer reféns em Edo, a fim de assegurar a lealdade do daimyo à autoridade central. Essa política tinha como finalidade provocar a sangria de recursos para impedir possíveis rebeliões contra o xogunato, uma vez que manter duas residências permanentemente e igualmente suntuosas, além de incluir inúmeras viagens, era uma dificuldade acrescida à solidez financeira. Além disso, a 
necessidade de uma grande comitiva de daymio residir por um longo período de tempo sem suas esposas e famílias, contribuiu para alimentar os distritos de prazer, posteriormente palco de grande inspiração entre os artistas.

Devido ao grande fluxo de informações e transferência de tendências entre cidade e periferia, o sistema político também fomentou o desenvolvimento cultural para além dos limites da capital. Breuer (1994), em seus estudos sobre a arte japonesa, descreve que o incentivo do governo por certas atividades artísticas como a caligrafia, a poesia, a pintura, a cerimônia do chá, entre outras, ajudou a ditar as ideologias políticas e os dogmas religiosos, de forma que a prática das artes não era apenas vocação pessoal, mas funcionava como expressão e exibição da autoridade da classe dominante.

Kano, uma das escolas de pintura oficial mais atuante da história japonesa, especializada em temas pictóricos e pinturas com estilo originário chinês, coexistia com as escolas literati, formadas por artistas intelectuais independentes que compartilhavam a mesma admiração pela cultura tradicional chinesa. Ambas também incorporavam elementos estéticos diferenciados desenvolvidos em seu país. Enquanto as tradições pictóricas chinesas tendiam a enfatizar o potencial do pincel para criar linhas e texturas expressivas, a estética japonesa priorizava cor e superfície, abordagem essa que não se limitou às artes pictóricas, mas acabou se manifestando em outros meios, especialmente nas artes aplicadas (GUTH, 1996).

Okano (2013) afirma que, diferentemente do Ocidente, a distinção entre as "belas artes" e as "artes aplicadas" no Japão era desconhecida. A criação artística não era uma tarefa subalterna, mas, pelo contrário, estava no mesmo nível de um poeta inspirado, ou seja, também ocupava um espaço privilegiado, pelo seu valor imaterial subjacente.

A vaga fronteira entre a arte e o artesanato pode ser visualizada pela constante presença da arte no cotidiano dos japoneses, tanto em forma de biombo, fusuma (portas de papel artesanal), de cerâmica ou da vestimenta quimono. A existência de uma zona de intermediação fluida entre o que o Ocidente considera belas-artes e arte popular é testemunhada pelo reconhecimento da figura dos artesãos no Japão. O governo considera alguns deles como "Tesouro Nacional Vivo do Japão", recebendo os artesãos uma honraria e uma remuneração por toda a vida. Essa conduta revela a ideia da indistinção entre as coisas materiais e imateriais (OKANO, 2010, p. 377). 
No Japão, no dizer de Cordaro (2008), as artes visuais englobavam um sistema de múltiplas expressões técnicas, de modo que a pintura nunca serviu para pura contemplação. Tinham seus aspectos pragmáticos uma vez que estavam sempre ligadas ora à decoração, ora aos leques, ora aos tecidos e têxteis, ora às narrativas laicas, religiosas ou aos livros ilustrados. Muitos artistas trabalhavam em vários campos, exercendo de forma simultânea diversos funções, de forma a não existir nítida distinção entre as artes visuais, literárias e a arte do espetáculo. Compreende-se, portanto, que o vestuário, a cerâmica, a laca e os acessórios abrangiam um sistema unificado, considerado não como artesanato ou "arte aplicada", mas, sim, como uma refinada arte. Cordaro (2008) acrescenta:

[...] até o encontro com as teorias estéticas do Ocidente, (a arte japonesa) insere-se em um sistema interligado que serve e é servido pelos outros modos irmãos de expressão da sensibilidade: a poesia, a recitação e a dança (CORDARO, 2008, p. 321).

A cerimônia do chá, por exemplo, era uma das muitas formas de arte que combinavam dois elementos, performáticos e visuais, de forma a não haver diferenciação e hierarquia entre as formas artísticas, distinção que é percebida no Ocidente.

Outra característica da arte japonesa enfatizada por Guth (1996) é o paradigma estrutural hierárquico das escolas oficiais, que assegurou a sua autoridade através dos anos. A acima referida escola Kano, responsável pela educação na pintura, manteve sua tradição artística por várias gerações, de modo que sua relevância por mais de três séculos é única na história da arte mundial. Por seu patrocínio residir nas mãos da corte, do xogunato e das instituições religiosas, a representação de temas decorativos de interesse, muitas vezes moralizantes, reforçou os valores éticos confucionistas. 
Figura 1 - Biombo do artista oficial Kitagawa Sôsetsu. Período Edo

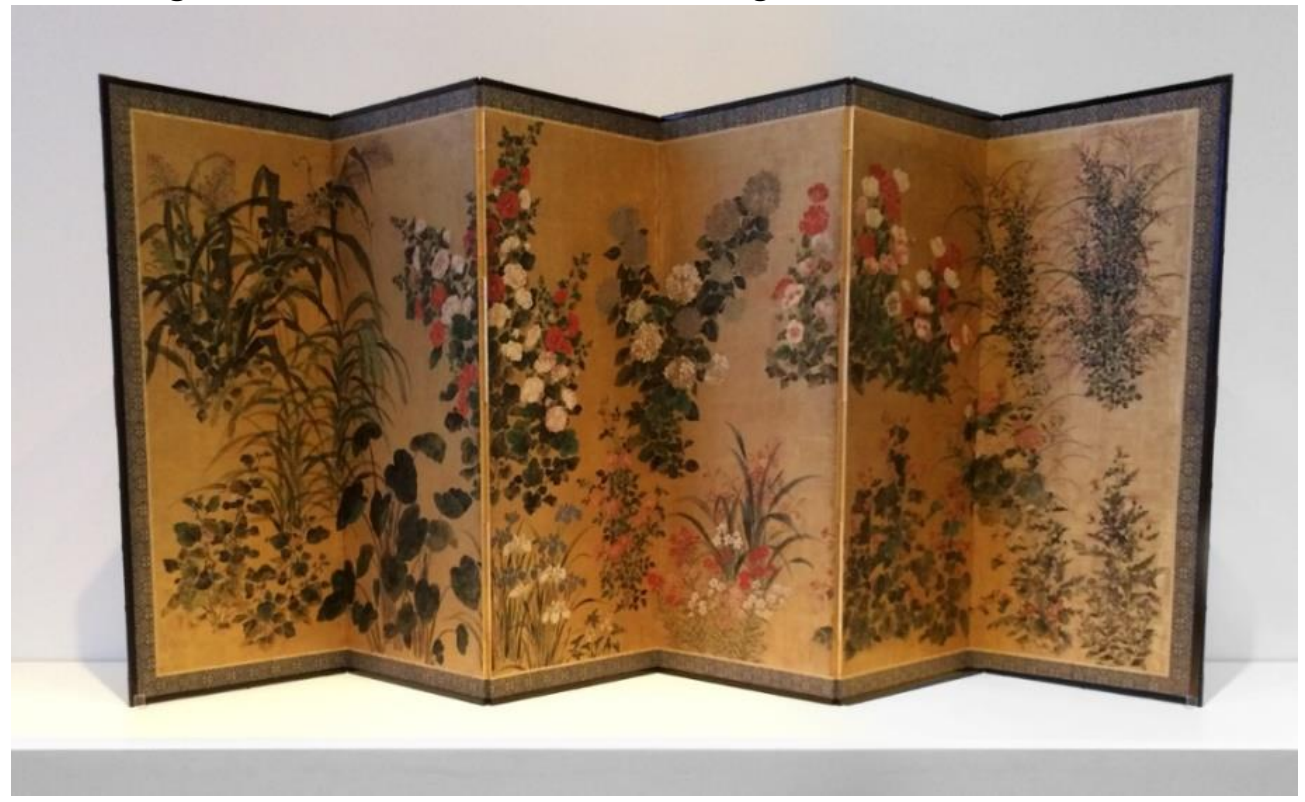

Fonte: Acervo de Luciana Iwamoto

Apesar dos esforços do governo em manter intacto o controle artístico e social intacto, o inédito contexto social pacífico, aliado ao crescimento urbano e à consequente concentração de riqueza em outras classes, leva a uma dramática e inevitável mudança de poder cultural ao longo do período Edo. Nessas circunstâncias, o xogunato possuia o controle dos temas e do estilo da arte oficial, porém, não possuía o poder de impor seus critérios às classes mais baixas, aos artistas, aos vassalos, ou, até mesmo, aos senhores feudais. Estes, mesmo não podendo ignorar o cânone oficial da decoração em suas residências, poderiam seguir os seus gostos e interesses pessoais no financiamento de obras para o uso privado.

Conforme o site do Metropolitan Museum of Art (2003), as escolas oficiais viveram a prosperidade somente enquanto associada intimamente ao governo; porém, sua relevância foi enfraquecendo conforme diminuía a fortuna de seus patronos, de modo que, no final do século XIX, funcionavam como um conjunto de pintores de tendência conservadora que era cada vez mais ofuscado por outros artistas inovadores, estes, muitas vezes se expressavam intencionalmente de maneira que não era sancionado pelo governo. Em virtude dessa espécie de contracultura consciente, Edo viu o patrocínio artístico aristocrático não só perder força, mas também ser substituído pela classe mais baixa do nível social.

Em uma sociedade feudal, a valorização do trabalho na terra era grande; o comércio era considerado atividade marginal por não produzir nada de relevante para a sociedade. A 
reativação dos princípios confucionistas como ideologia de governo, segundo Guth (1998) e Santos (2011), era especialmente interessante para o Estado, uma vez que amparava o sistema hierárquico social do xogunato. Desse modo, nesse sistema, os comerciantes posicionavam-se no mais baixo nível social, precedido pelos samurais - os soldados da aristocracia - no topo e, em seguida, sucessivamente, por fazendeiros e artistas (atores, cortesãs e criminosos não eram considerados).

Apesar dessa rígida hierarquia social, a classe de artesãos e comerciantes passou a ser bem mais numerosa e, ao fornecerem bens e serviços nos crescentes centros urbanos, progressivamente ganharam força econômica. Essa classe, a partir de então, se encontrou em posição paradoxal pelo fato de ser, ao mesmo tempo, economicamente poderosa, mas socialmente confinada, excluída de qualquer participação política e impossibilitada de ascensão social. Por conseguinte, entrega-se à prática e ao patrocínio de atividades culturais previamente monopolizados pela elite. Simmons (1958), relata que as artes, o consumo conspícuo e a busca pelo prazer nos distritos de entretenimento formam uma nova e ávida subcultura criada especialmente por eles e para eles, conhecida como ukiyo.

\subsection{O MUNDO FLUTUANTE}

Como forma de refúgio à rígida hierarquia social e à repressão ditatorial, o ukiyo, ou mundo flutuante, floresceu ao longo de todo Período Edo. Originalmente era um termo budista com conotações de tristeza e transitoriedade; nesse novo contexto, porém, significava os prazeres hedonistas e fugazes e consistiu em formas e locais de entretenimento como casas de chá, restaurantes próximos à ponte Ryōgoku, feiras de rua, festivais e atividades culturais como teatro (kabuki), arte, literatura, caligrafia e música; ou seja, o perfeito cenário para a diversão e o ócio da classe dos novos ricos (GUTH, 1998). Breuer (1994) atesta que cortesãs, músicos, atores, lutadores de sumô e poetas contribuíram para a ascensão e a popularidade do ukiyo, com destaque às glamorosas gueixas e atores do teatro kabuki, que possuíam enorme influência sobre a população, tornando-se agentes disseminadores de tendências. 
A primeira descrição dessa sociedade foi feita pelo escritor da cidade de Quioto Asai Ryôi (1612-1691), no prefácio de sua obra Contos do Mundo Flutuante, de meados de 1661, e se tornou a definição clássica:

Viver apenas o momento. Entregar-se inteiramente aos prazeres da lua, da neve, das flores de cerejeira e das folhas de bordo; cantar, beber vinho, distrair-se enquanto flutua, flutua; não se importando com o pauperismo em nossa frente, recusando-se a se sentir desmotivado, como uma cuia que flutua, juntamente com a corrente do rio: é o que chamamos de mundo flutuante (LANE, 1978, p. 11).

Nesse contexto, Guth (1996) afirma que se estabeleceu o universo do qual a classe mercantil desfrutava e com o qual se identificava. Mas, apesar do pedido oficial para que a população se abstivesse das frivolidades do mundo flutuante, ele acabou a atingir todos os níveis sociais, incluindo a alta classe de samurais, de modo que prejudicou a hegemonia artística do xogunato, mas que contribuiu para um novo pluralismo cultural e artístico.

Como consequência natural, além da participação das formas de entretenimento, mostrou-se necessário expor a prova material de toda aquela prosperidade. Nesse cenário, surgem as imagens do mundo flutuante, chamadas ukiyo-e (e significa imagem), a manifestação artística mais onipresente desse período. Guth (1996) ainda acrescenta que essa e outras formas de arte que se desenvolveram nesse período expuseram a necessidade de novas maneiras de representar, que surgiram na urgência de refletir essa classe e seus interesses.

\subsection{O UKIYO-E - A ARTE DAS MASSAS}

É no contexto do surgimento de novos valores sociais e culturais alternativos associados ao mundo flutuante que nasce o ukiyo-e. Longe de representar uma escola oficial, patrocinados pela aristocracia japonesa e pelo xogunato, o ukiyo-e surge como um movimento artístico independente que, em função da ascensão e do patrocínio econômico burguês, impôs os gostos mais realistas e mais apegados à realidade cotidiana. Como retratos de uma subcultura, o ukiyo-e assimilou a atitude despreocupada em que emergiu, em contraste com 
as grandes obras de temática moral e religiosa retratadas até então. A frequente expressão "escola ukiyo-e" existe para designar grupos de artistas que se organizavam em torno de um mentor ou mestre; porém, alguns artistas foram influenciados por mais de um mestre e outros não se associaram a qualquer escola em particular (GUTH, 1996).

Por definição, ukiyo-e significa literalmente "imagens do mundo flutuante" e consiste em xilogravuras populares muito em voga no Japão entre os séculos XVIII e XIX. Essa técnica de impressão, feita através de blocos de madeira, já era utilizada no país desde o século VIII para a divulgação de textos, e permaneceu essencialmente com a mesma função até o século XVIII, quando, por intermédio do ukiyo-e, ocorreu o uso inovador dessa técnica secular.

O conceito-chave da estética das estampas ukiyo-e é a sua natureza efêmera, tanto da própria arte como de seus temas. Diferentemente das pinturas, feitas para serem mantidas e valorizadas e, portanto, atribuídas somente à nobreza, a natureza passageira do ukiyo-e o colocava em posição fisicamente temporário, mas que, ao mesmo tempo, permitiu a sua comercialização e distribuição de forma ágil e acessível. Segundo Guth (1996, p. 99):

[...] gravuras poderiam ser produzidas rapidamente, de forma relativamente barata e em grande número, tornando-as extremamente sensíveis à última moda e às políticas. Os preços variavam dependendo da dimensão e qualidade, mas no século XIX o preço de uma gravura era praticamente o mesmo que uma tigela de macarrão, uma refeição para a maioria dos plebeus.

Em função dessas particularidades, as gravuras tornaram-se o meio de expressão que melhor captou a essência dos traços culturais da capital: o fascínio pela novidade, o orgulho dos marcos locais e, especialmente, a esperança e os sonhos da população, elementos indissociáveis da vida urbana que as escolas tradicionais, que valorizavam a tradição acima da inovação, não conseguiram acompanhar. No contexto da rígida estrutura social, os mestres do ukiyo-e apresentavam ao público algo que ele almejava, mesmo que inconscientemente, de forma que cabe aqui a mesma afirmação de Souza (1987, p. 31) em relação ao criador de moda, também sensível ao momento social: “Como um poeta, ele é apenas o porta voz de uma corrente que se esboça e cuja tomada de consciência antecipa", de modo a justificar o sucesso imediato dessas gravuras nesse período em específico. 
Segundo Breuer (1994), as primeiras gravuras na técnica de xilogravura majoritariamente faziam parte de livros que surgiram em resposta à população cada vez mais letrada e consistia em ilustrações construídas apenas com contornos pretos (Figura 2). Uma vez que as ilustrações foram consideradas mais importantes que o próprio texto, são publicadas impressões independentes e desarticuladas de livros e, nesse momento, eleva-se o nível dessa forma de expressão artística.

Figura 2 - Início do ukiyo-e. Duas mulheres e um homem no portão.

Parte integrante de um livro. Hishikawa Moronobu, século XVII

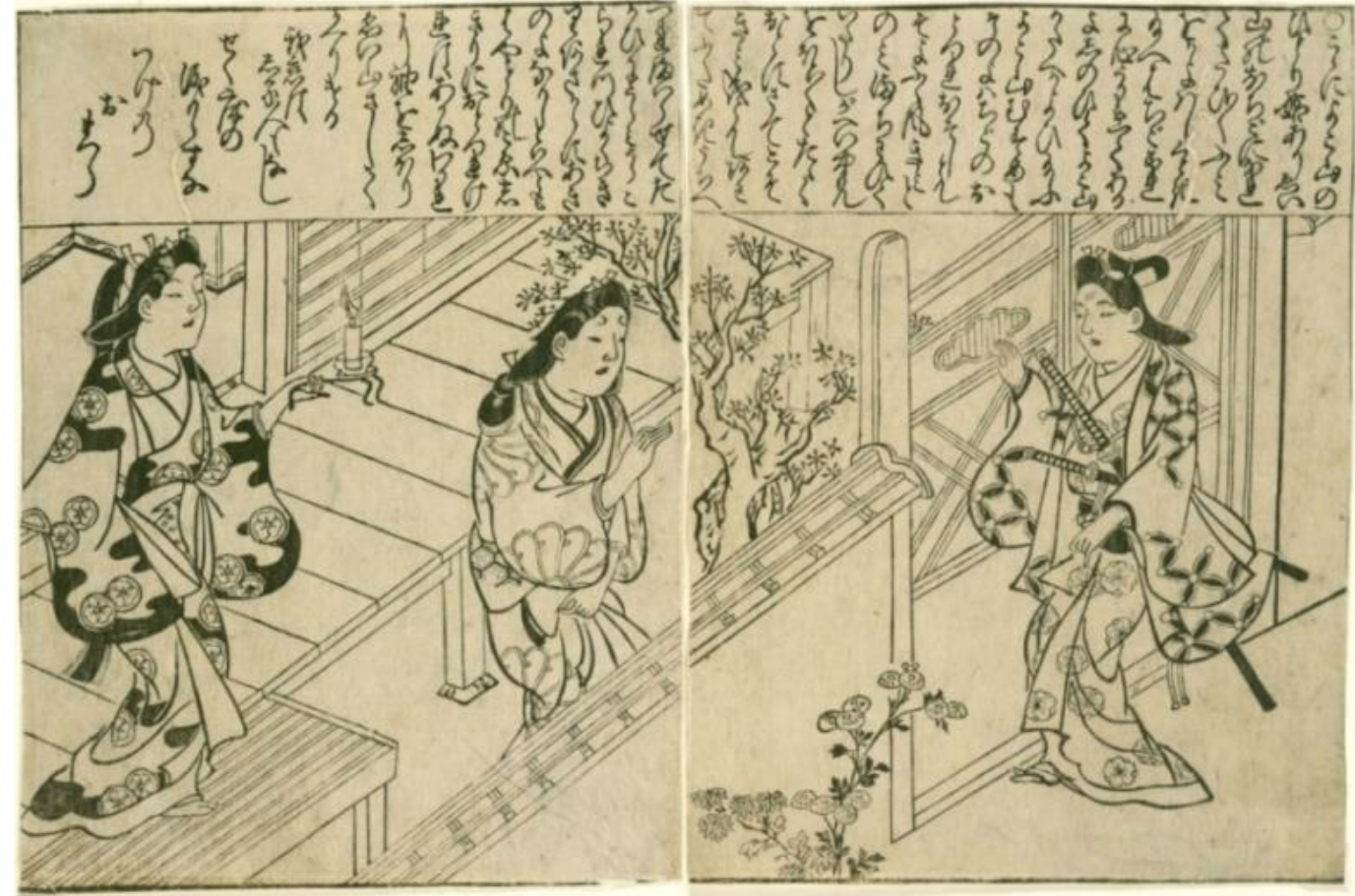

Fonte: http://learningobjects.wesleyan.edu/blockprinting/flash/main.html

Ainda de acordo com Breuer (1994), outras inovações surgiram ao longo do percurso, como a aplicação de cor de forma manual (Figura 3), a utilização de símbolo único como marca de autoria do projeto (Figura 4) e a padronização dos tamanhos para gravuras individuais. 
Figura 3 - Contemplação de árvores de cerejeira. Xilogravura com cor aplicada à mão. Hishikawa Moronobu, século XVII

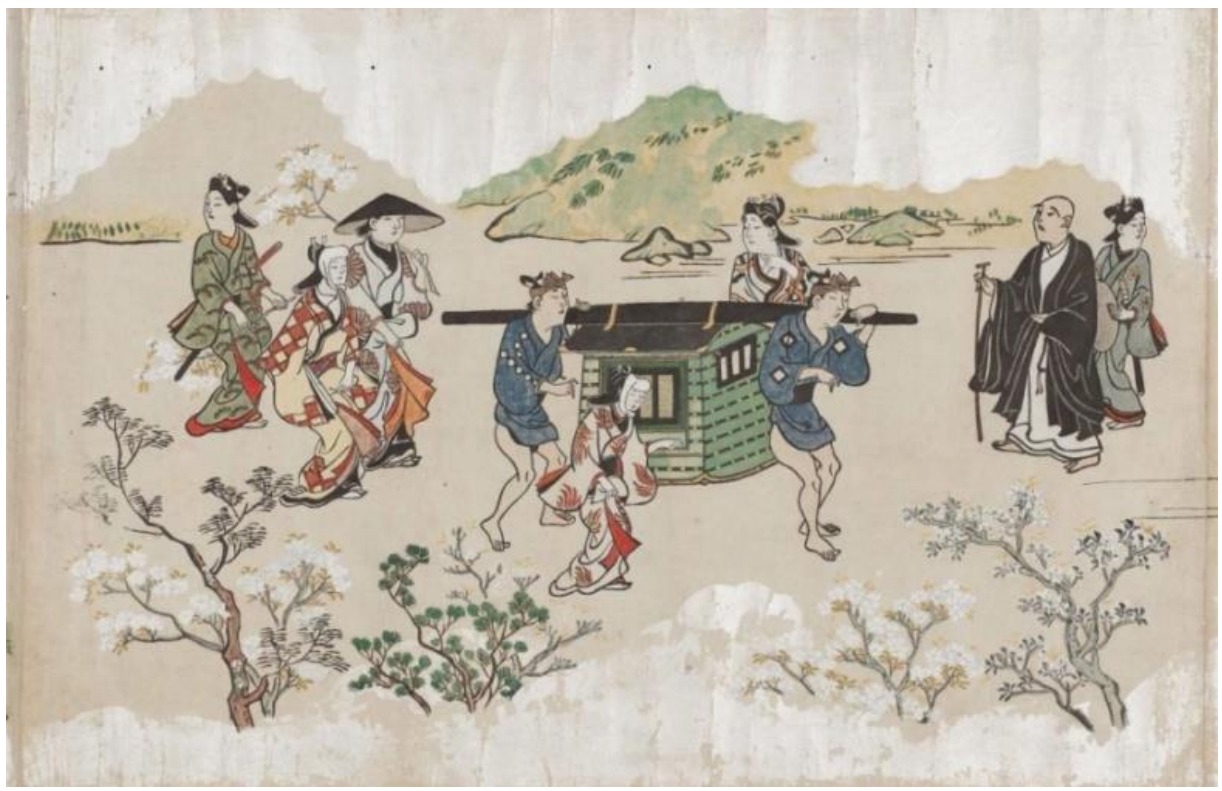

Fonte: http://ukiyo-e.org/source

Em 1760, devido ao seu alto custo, as gravuras com cor aplicada saíram de moda em Edo e a alternativa foi substitui-las pelo processo de policromia. Com essa nova forma de produção, o ukiyo-e atinge sua maturidade e, em virtude das suas cores suntuosas e brilhantes, fica conhecido também como "pintura-brocado" (nishiki-e) (KLEINER, 2012). Guth (1998), refere que, no início, o número de cores era limitado em quatro, mas a partir da segunda metade do século XVIII, apareceram as gravuras com doze cores ou mais. Cada cor demanda um bloco, entretanto, não raro, para contenção de custo, entalhava-se em ambos os lados do bloco de madeira, reduzindo esse número pela metade.

Kleiner (2012) sustenta que os artistas ukiyo-e, muitos provenientes das escolas ortodoxas, geralmente eram pintores que não participavam da produção de suas gravuras, e sim idealizavam e desenhavam o produto final, de maneira que o próprio ukiyo-e era um produto híbrido entre belas artes e artes aplicadas, mesmo que no período não houvesse essa distinção. A produção desse complexo processo dependia do esforço colaborativo de vários profissionais. Além do artista, fazia-se necessário o trabalho do entalhador, do impressor e do editor, que, por sua vez, também desempenhava papel na criação, pois além de fornecer subsídio à obra, adaptava os desenhos a serem impressos. Por conta disso, o nome de ambos, artista e editor, apareciam no produto final, de modo que não raro, também era requisitado um quinto profissional, o calígrafo (OKANO, 2013). 
Figura 4 -O jardim de ameixa em Kameido. Da série Cem famosas vistas de Edo. Utagawa Hiroshige, 1857

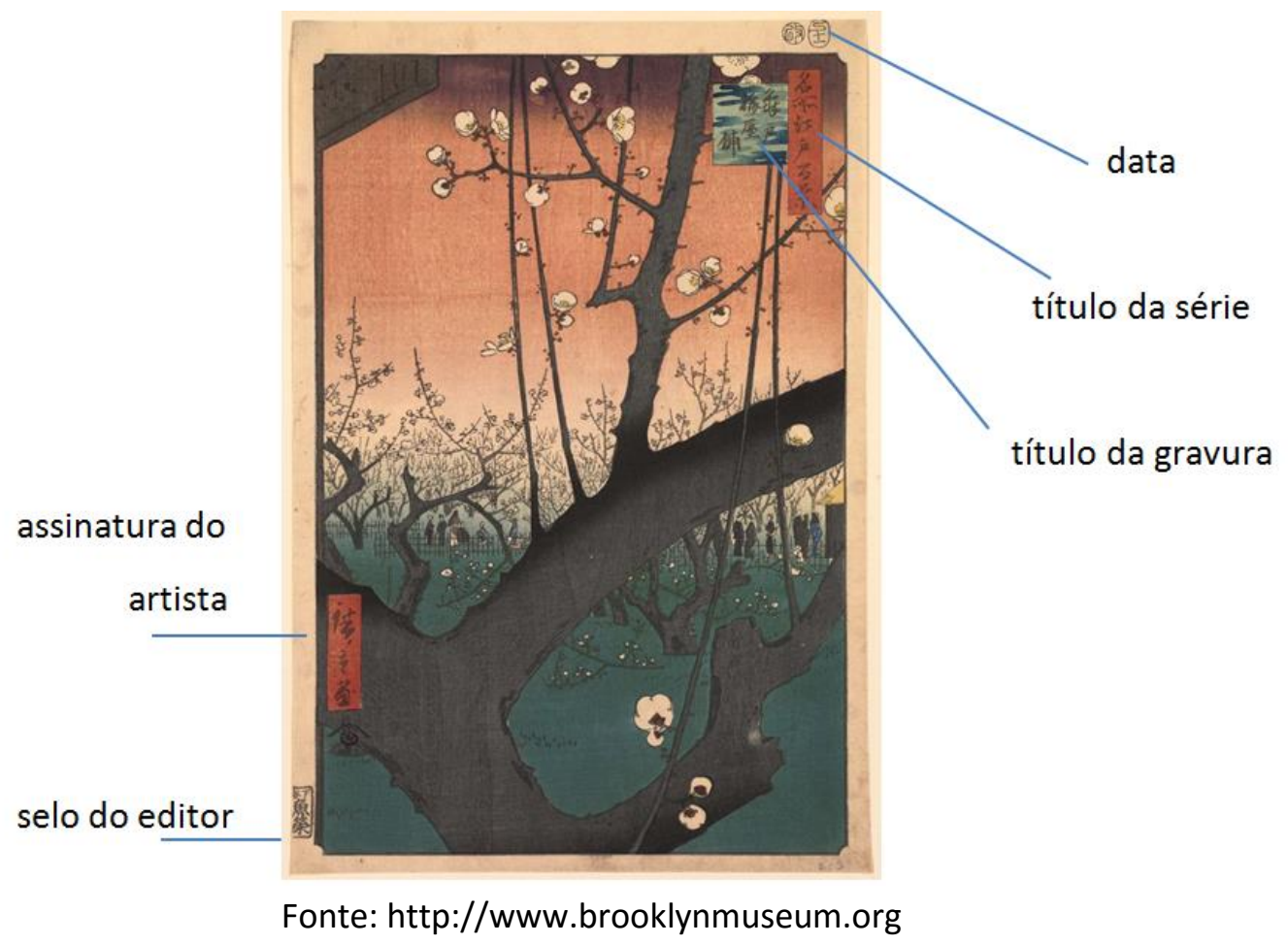

É interessante perceber que a demanda de produtos artísticos por parte do grande público fez com que a técnica xilogravura fosse o sistema de produção mais adequado: barato e acessível, era possível qualquer cidadão modesto adquiri-la a um preço módico nas muitas lojas e feiras espalhadas pela cidade. A predileção por essa técnica ou, talvez, sua consequência, resultou em elementos estéticos e decorativos que, posteriormente, seriam incorporados aos ocidentais. Os contornos pretos, a título de exemplo, possuíam a necessidade técnica de delimitar áreas de cores distintas no processo de produção das gravuras e podem ser vistas em muitas obras de arte ocidentais.

É ainda já possível traçar um paralelo entre os artistas do ukiyo-e e os pintores vanguardistas franceses que, posteriormente, serão abordados neste trabalho. Assim como os artistas do ukiyo-e, um grupo de artistas do século XIX também rejeitaram a arte tradicional e buscaram novos métodos e técnicas de representação, de modo especial em relação à busca de temas mais íntimos do cotidiano. O diferencial entre eles e os japoneses, confinados nos limites de sua pequena ilha, é que os japoneses praticamente não possuíram influência externa no desenvolvimento da própria arte, mas buscaram na própria tradição seus meios. 
No subitem a seguir serão abordados os principais fundamentos da estética japonesa que também se estendem a outras esferas e, por consequência, às gravuras ukiyo-e, que serão analisados posteriormente em simultâneo ao contexto europeu do final do século XIX.

\subsection{A ESTÉTICA JAPONESA}

Através dos séculos, muitos aspectos culturais primitivos, dogmas religiosos, princípios éticos e filosóficos importados de variados países, principalmente da China, introduziram-se na cultura do povo japonês de forma profunda. Okano (2012, p. 1140) afirma: "A China foi o "centro" para os japoneses durante muitos séculos. O Japão importou do país continental a sua escrita ideogrâmica; a religião budista; a estrutura social e política [...]".

Para Guth (1998), foi principalmente a religião - baseada em diversos princípios derivados do xintoísmo, do confucionismo, do taoísmo, do budismo e do zen budismo - que exerceu forte influência cumulativa na formação dos complexos conceitos estéticos japoneses. A justaposição ou a sobreposição - e não fusão - das diversas doutrinas articulavam-se também a outras práticas locais, atribuindo novos sentidos, de forma a gerar o "sincretismo filosófico" único; este, não só moldou os componentes estéticos tradicionais, mas também estruturou a forma de pensar e de agir dos indivíduos.

Parkes (2011), ao estudar a estética japonesa, ressalta que a proximidade consciente das práticas confucionistas, por exemplo, fez com que a cultura e as artes tendessem a ser estreitamente associadas com ao intelecto e à vida da mente mais do que nas tradições ocidentais; desse modo, não raro até hoje um estudante, além de possuir as habilidades intelectuais pertinentes, ser também um excelente calígrafo e poeta.

Para Miklos (2010), que escreveu sobre a arte zen, ensina que os conceitos provenientes do Zen foram provavelmente os que mais influenciaram o desenvolvimento da arte de forma significativa, com os seus exemplos mais consideráveis, a pintura e a caligrafia. Esses conceitos, que aqui interessam mais do que as próprias doutrinas, expõem as condições de criação às quais as obras foram produzidas.

Um desses conceitos norteadores é que a filosofia clássica japonesa entende a realidade básica em uma constante mudança, ou, para usar a expressão budista, 
impermanência, de forma que a estética é centrada na aceitação da transitoriedade e da imperfeição (PARKES, 2011). Sabe-se que o ensino de arte das academias ocidentais é baseado em metodologias clássicas e também que tem por finalidade obter efeitos estéticos com o uso de luz, sombra e contrastes, fundamentado em cópia de obras consagradas. Diferentemente dos ocidentais, o estudo no Oriente se concentrava mais no percurso em si, de forma que a imitação das obras não tinha como objetivo a reprodutibilidade técnica, mas, sim, a ação criativa que vai além do próprio objeto de arte, ainda que o incluísse.

Ainda de acordo com os escritos de Miklos (2010), o ideal não representa apenas a qualidade de beleza inerente à arte realizada; porém abrange a prática contemplativa e a experiência corporal (disciplina, concentração, aprimoramento técnico). A meditação e a concentração eram habilidades a serem adquiridas que, conforme Gombrich (1993), são difíceis de serem captadas pelos ocidentais inquietos e com escassos conhecimentos da técnica de concentração. Okakura $(2013$, p. 22), reconhecido escritor, estudioso e curador de arte japonês declara que "a concepção Zen e Taoísta de perfeição era diferente. A natureza dinâmica de sua filosofia depositava mais ênfase no processo através do qual a perfeição era procurada, e não na perfeição em si mesma".

Era preferível encontrar nas pinturas os traços entusiasmados do artista, que mostram a habilidade no manuseio com o pincel, ao invés da constante busca do realismo: "os orientais consideravam uma infantilidade procurar detalhes em pinturas e depois compará-las com o mundo real" (GOMBRICH, 1993, p. 110).

Vincent van Gogh (1853-1890), artista pós-impressionista, deslumbra-se ao analisar a estética oriental, documentado em uma carta para seu irmão Theo, de 1888 (RUGER, 2009, n.p.):

Invejo nos japoneses a extrema limpidez que tudo tem em seu trabalho. Ele nunca é entediante, e nunca parece feito às pressas. Seu trabalho é tão simples como respirar, e eles fazem uma figura com algumas pinceladas seguras tão facilmente como se abotoa um paletó

O conceito de perfeição para os orientais, portanto, muito se difere da concepção ocidental, de modo que a beleza é associada à natureza, imperfeita e impermanente.

Hisamatsu (1971 apud MIKLOS, 2010, p. 64) define que "Enquanto ordinariamente qualquer forma é reverenciada se for perfeita, no Zen a perfeição da forma, não importa quão 
completa, não é a verdadeira perfeição. Ao contrário, será a Não-Forma [...] que indica a perfeição".

Nesse sentido, o aspecto relativo e potencialmente intercambiável das coisas pela da negação da forma, corresponde ao conceito budista de vazio. Essa concepção, primordial do pensamento estético oriental, não significava a não-existência, a ausência ou a morte, mas desempenha o símbolo do abstrato e da possibilidade. De acordo com Okano (2014, p. 151) "distinto de uma concepção ocidental cujo significado é o nada, (a associação de vazio no Oriente) é visto como algo do nível da potencialidade, que tudo pode conter e, portanto, da possibilidade de geração do novo".

A verdadeira beleza, por conseguinte, somente pode ser descoberta por aquele que completa mentalmente o incompleto, assim como a virilidade da vida emerge em suas possibilidades de crescimento.

No espaço pictórico, essa intensificação do conceito de vazio é representado, em níveis mais evidentes, na exploração dos espaços em branco ao redor do tema principal. Essa singular concepção, denominada $M a$, não está restrita às artes, mas perpassa diversos aspectos da vida dos japoneses, desde a arquitetura, a religião, até a condução das relações e interações pessoais. Em suma, a história da estética japonesa também é a história dos ideais japoneses.

A simetria, outro componente que, para a percepção ocidental, pressupõe-se como sinônimo de beleza, equilíbrio e, consequentemente, perfeição, na concepção oriental é evitada, pois, conforme Okakura (2003, p. 22), é considerado "como uma expressão não apenas de totalidade, mas de repetição. Uniformidade de aparência era considerada fatal para a liberdade de imaginação".

Hisamatsu, acima referido, ainda completa que a assimetria, ao mesmo tempo em que é associada à falta de regularidade, igualmente significa a negação, a fuga consciente das formas fixas e, por consequencia, da monotonia (MIKLOS, 2010).

O professor da Universidade de Belas Artes de Quioto, Hoseki Shin'ichi Hisamatsu (1889-1980) (1971, apud MIKLOS, 2010) definiu as sete características estéticas do Zen, que ele traduziu como: 
- assimetria

- simplicidade

- austeridade

- naturalidade

- sutil profundidade

- desapego

- quietude

Essas características, atribuídas a vários fatores, como, por exemplo, sociais, filosóficos e culturais inter-relacionados, desenvolveram-se em componentes estéticos muito distintos, às vezes opostos, ao ideal estabelecido no ocidente; por isso, puderam auxiliar na ruptura artística ocidental. Muitas delas foram recebidas pelos europeus por meio da gravura ukiyo-e que, mesmo sem se configurar como arte oficial, deriva dos mesmos conceitos tradicionais.

Analisa-se a influência japonesa na Europa, principalmente, através do trabalho de três grandes mestres do ukiyo-e: Kitagawa Utamaro (1753-1806), Katsushika Hokusai (1760-1849) e Andô Hiroshige (1797-1858) (conhecido como Utagawa Hiroshige). Além de sua notoriedade, a escolha desses três nomes baseia-se no seguinte fato: o conceito estético das gravuras japonesas se desenvolveu ao longo de mais de duzentos anos; mas a maioria das composições que cativaram e influenciaram os europeus no período oitocentista eram produções datadas de cem anos anteriores à abertura dos portos japoneses em 1854 (BREUER, 1994). Porém, os elementos contidos em suas obras caracterizam a expressão artística japonesa como um todo, também derivados dos diferentes sistemas simbólicos e culturais que coexistiam de forma harmoniosa na tradição japonesa.

\subsubsection{Os mestres do ukiyo-e}

Conhecido principalmente em função de suas magistrais representações de belas cortesãs, Kitagawa Utamaro é um dos grandes nomes das estampas ukiyo-e do século XVIII. Atuante em Edo, seu trabalho foi marcado pela temática da exploração da diversidade 
feminina, revelada mediante sutis nuances de poses, gestos e traje. Retratados de forma idealizada, seus corpos altos e magros, longos pescoços e ombros estreitos, longos narizes e olhos e bocas como pequenas fendas, representavam o padrão de beleza da época e ajudaram a perpetuar o fascínio do público frente àquela realidade alternativa (GUTH, 1998).

Figura 5 - Duas mulheres com leque ao lado de um córrego. Da série As seis elegantes do Rio Tama, c. 1802

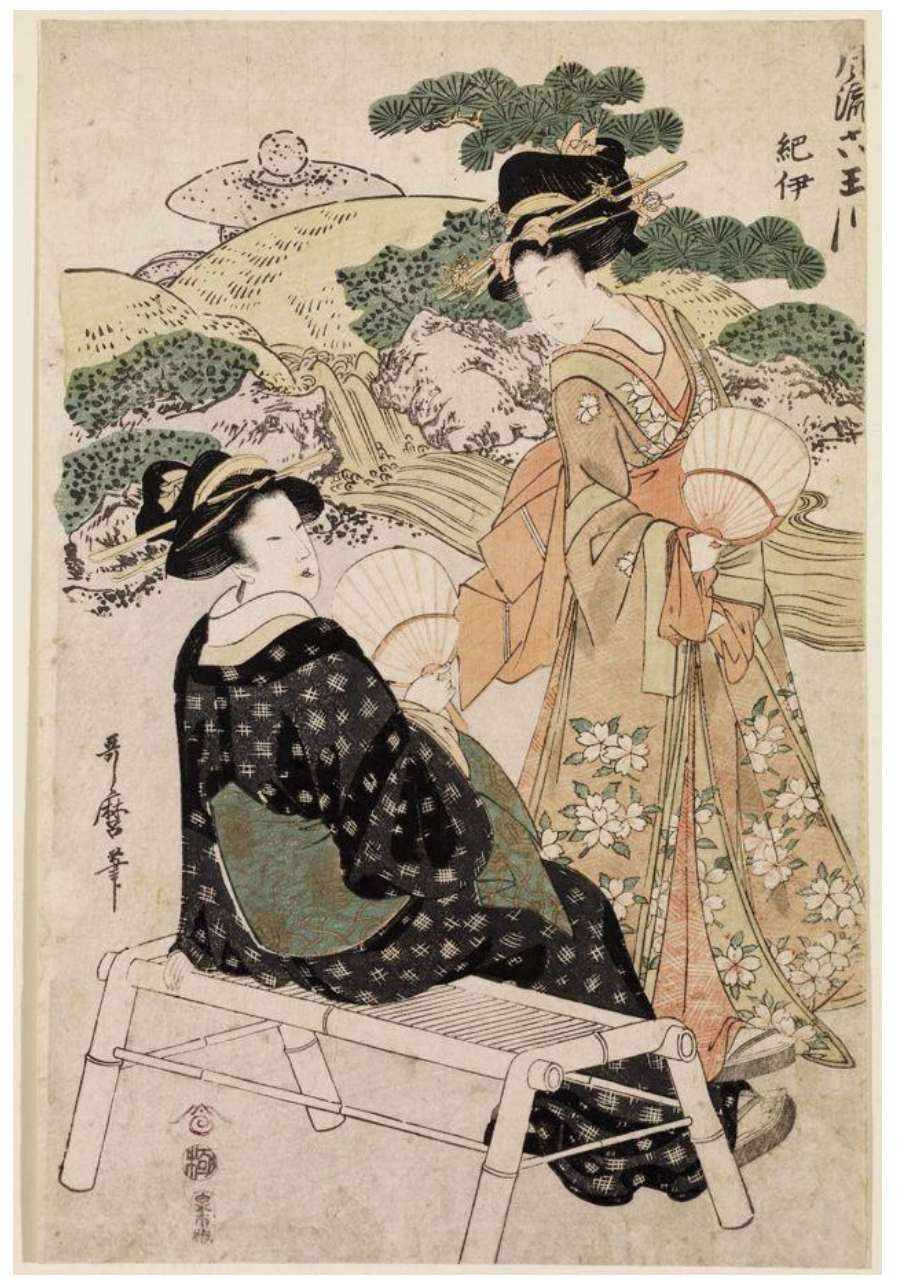

Fonte: http://ukiyo-e.org

As belas mulheres (Figura 5) representadas por Utamaro, no dizer de Breuer (1994, p.53), "foram consideradas como árbitros das tendências na sociedade do mundo flutuante, e muitas vezes exerciam o papel de manequins, vestindo os mais recentes estilos de moda", de forma que é certo afirmar que muitas de suas gravuras configuravam-se como ilustrações de moda do período. Ele também desenvolveu um amplo trabalho com imagens femininas 
envolvidas em cenas domésticas. Banhar-se, pentear-se ou educar os filhos eram situações cotidianas dignas de serem representadas.

Lambourne (2005) afirma que seu grande reconhecimento foi devido ao seu alto nível de detalhamento, ou seja, a sutileza e a atenção aos detalhes. As impressões de Utamaro exibiam uma maestria incomum, que Ihe trouxe fama ainda em vida. Mesmo através da complexa produção da xilogravura, ele conseguiu expor toda uma gama de emoções por intermédio dos tecidos do vestuário das suas elegantes mulheres, que possuíam drapeados, translucidez, transparência e movimento, como mostra a Figura 6.

Ademais da perfeição técnica, outra característica não só de Utamaro, mas da gravura ukiyo-e, era a utilização simultânea de múltiplos padrões; ou seja, além da função de distinguir os vários elementos de uma composição - assim como os contornos pretos que separavam as cores e os dividiam em seções - possuíam uma função altamente decorativa.

Figura 6 - Amantes no andar de cima da casa de chá. Kitagawa Utamaro, 1799

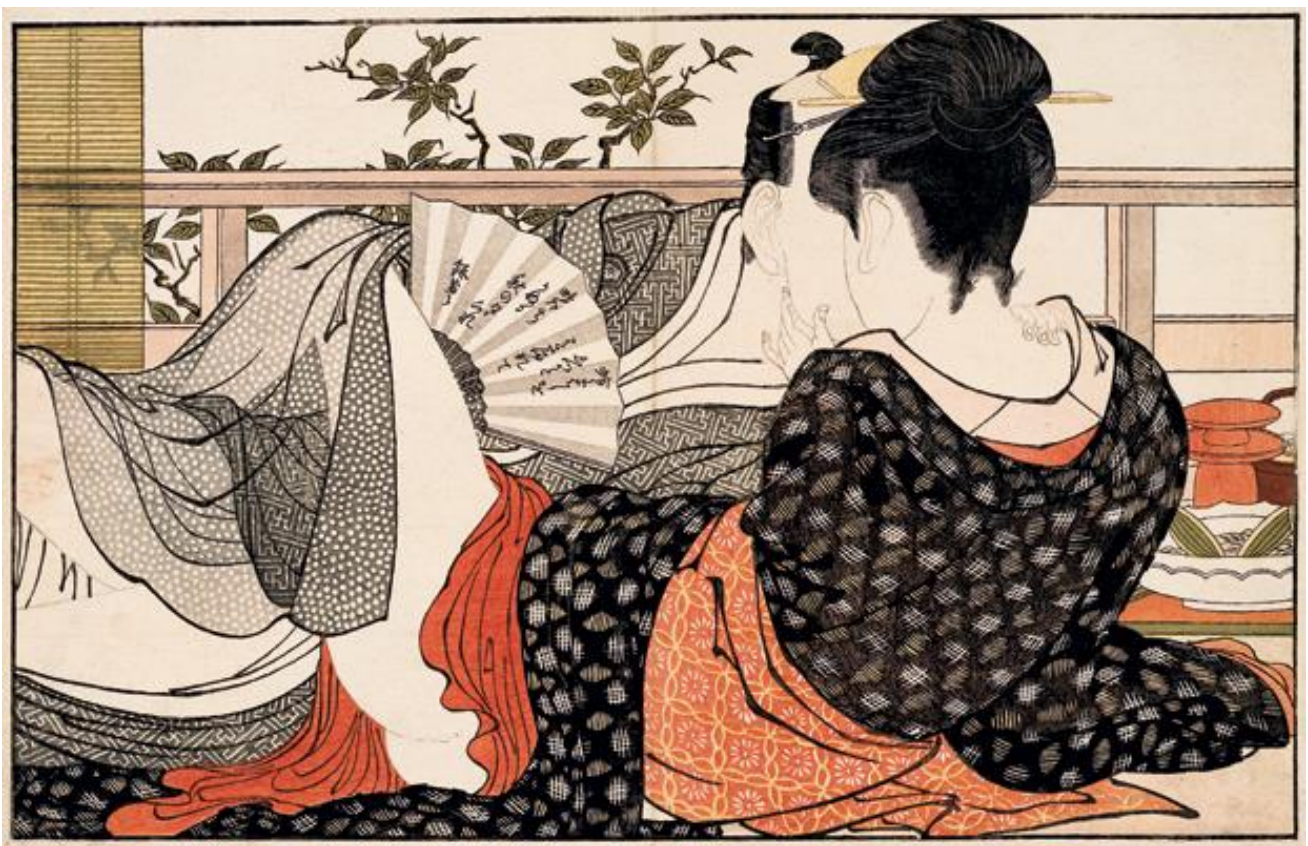

Fonte: http://ukiyo-e.org/artist/kitagawa-utamaro

Em 1842, gravuras de atores, dançarinas e cortesãs foram proibidas, de modo que os artistas se voltaram a temáticas alternativas, preponderantemente relacionadas com a natureza. Segundo Lambourne (2005), as paisagens, que até então eram apenas acessórios de ambientação, foram gradualmente adquirindo maior destaque, retratadas sob novas 
perspectivas. Desde o início do período Edo, houve um aumento nas viagens internas - talvez por amenizar a sensação de confinamento instalada pelo governo - exercício esse que resultou em paisagens não mais retratadas de forma idealizada, com disposição específica de elementos, mas, sim, com uma interpretação baseada em locais reais e pontos de vista também reais. A esse respeito, o registro de Breuer:

Por volta do século 19, viagens recreacionais eram uma atividade popular para os moradores da cidade que procuraram escapar das limitações da cidade e para os curiosos sobre a vida além dos limites urbanos. [...]. Os artistas forneceram desenhos de paisagem, que os imprimiram uma por folha, em séries ansiosamente esperadas (BREUER, 1994, p.16).

A primeira grande série de paisagens produzida foi a denominada Trinta e seis visões do Monte Fuji, de Katsushika Hokusai, desenvolvida em resposta ao aumento das viagens domésticas e da sua pessoal fascinação pelo tema. Hokusai era um artista versátil que retratava desde flores a imagens eróticas, mas ficou conhecido principalmente devido às suas paisagens que punham em evidência as pessoas comuns em suas atividades diárias (STRANGE, 1906).

Uma das imagens integrante da série Trinta e seis visões do Monte Fuji, A Grande Onda de Kanagawa (Figura 7), comumente conhecida apenas como "A Onda", configura-se não só como o mais famoso ukiyo-e, como, provavelmente, é a obra de arte japonesa mais emblemática do mundo.

Mediante a utilização das diferentes escalas dramáticas, Hokusai, em sua "A Onda", contrasta a potência da natureza diante da fragilidade humana. A onda, ameaçadora, é retratada em seu momento de clímax, apenas segundos antes de desabar nos três barcos de pesca. Essa instabilidade é alcançada por meio do recurso da assimetria, muito utilizado por ele, no qual o peso visual se encontra fora do centro. Esse aspecto, que resulta em estruturas com largas expansões de céu, água ou terra, em organizações do espaço que ficam à mercê da imaginação do observador, possuiu grande impacto entre os pintores franceses do século XIX. Van Gogh, por exemplo, escreve para seu irmão Theo: "essas ondas são como garras, o barco está preso nelas, podemos sentir" (RUGER, 2009, n.p.). 
Figura 7 - A Grande Onda de Kanagawa. Katsushika Hokusai, entre 1830 e 1832

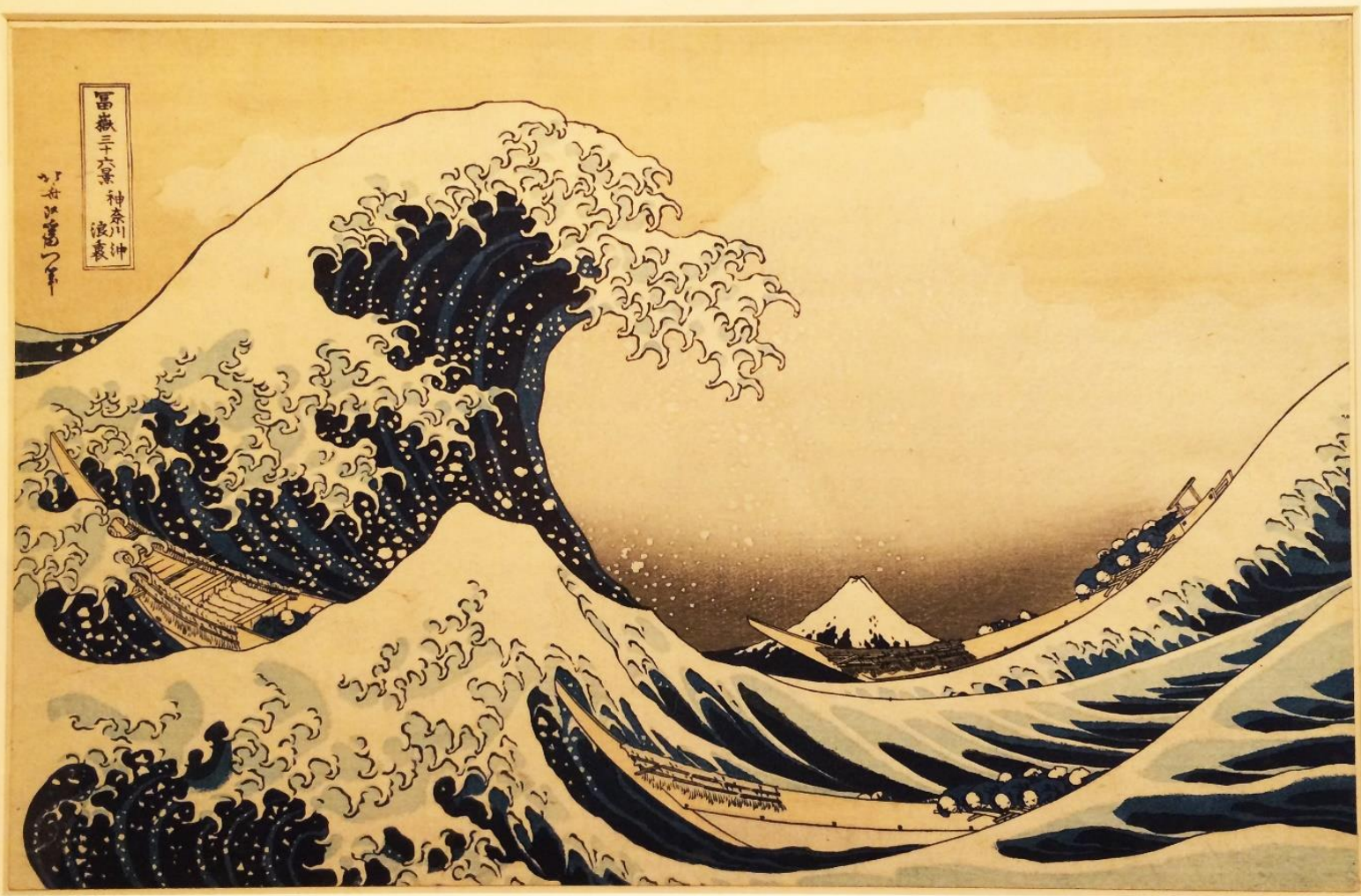

Fonte: Acervo de Luciana Iwamoto

Essa imagem não só inspirou os pintores franceses do período oitocentista como também o compositor Claude Debussy (1862-1918), que a expôs na capa de seu célebre poema sinfônico La Mer de 1905. Em demonstração da notoriedade de Hokusai ainda nos dias atuais, o Grand Palais de Paris, entre 1 o outubro de 2014 e 18 de janeiro de 2015, abrigou a exposição intitulada "Hokusai" (Figura 8). Na descrição do pôster de divulgação, lê-se:

Katsushika Hokusai (1760-1849) é hoje o mais famoso artista japonês em todo o mundo. Seu trabalho de pinturas, desenhos e gravuras incorpora a espiritualidade e a alma do país, especialmente suas gravuras de paisagens, síntese notável entre os princípios tradicionais da arte japonesa e influências ocidentais.

É importante destacar que, apesar da notoriedade de Hiroshige em terras ocidentais, a influência é recíproca. O pigmento azul prussiano, também denominado azul berlim, utilizado na célebre imagem A Grande Onda de Kanagawa e em várias outras da série Trinta e Seis Visões do Monte Fuji, só foi possível devido ao contato com o ocidente (SMITH II, 2015). 
Oguro (2013) afirma que essa tonalidade sintética possui origem europeia e chegou ao Japão através do comércio com os holandeses e, ironicamente, ficou conhecida no Ocidente como "azul de Hokusai".

Esse fato deixa evidente que, quando se constrói uma ponte entre duas culturas, a via é sempre de mão dupla. Hokusai e Hiroshige, os mais influentes entre os artistas europeus, eram, surpreendentemente, "contaminados" pelo Ocidente.

Figura 8 - Exposição dedicada a Hokusai. Grand Palais, Paris, 2014

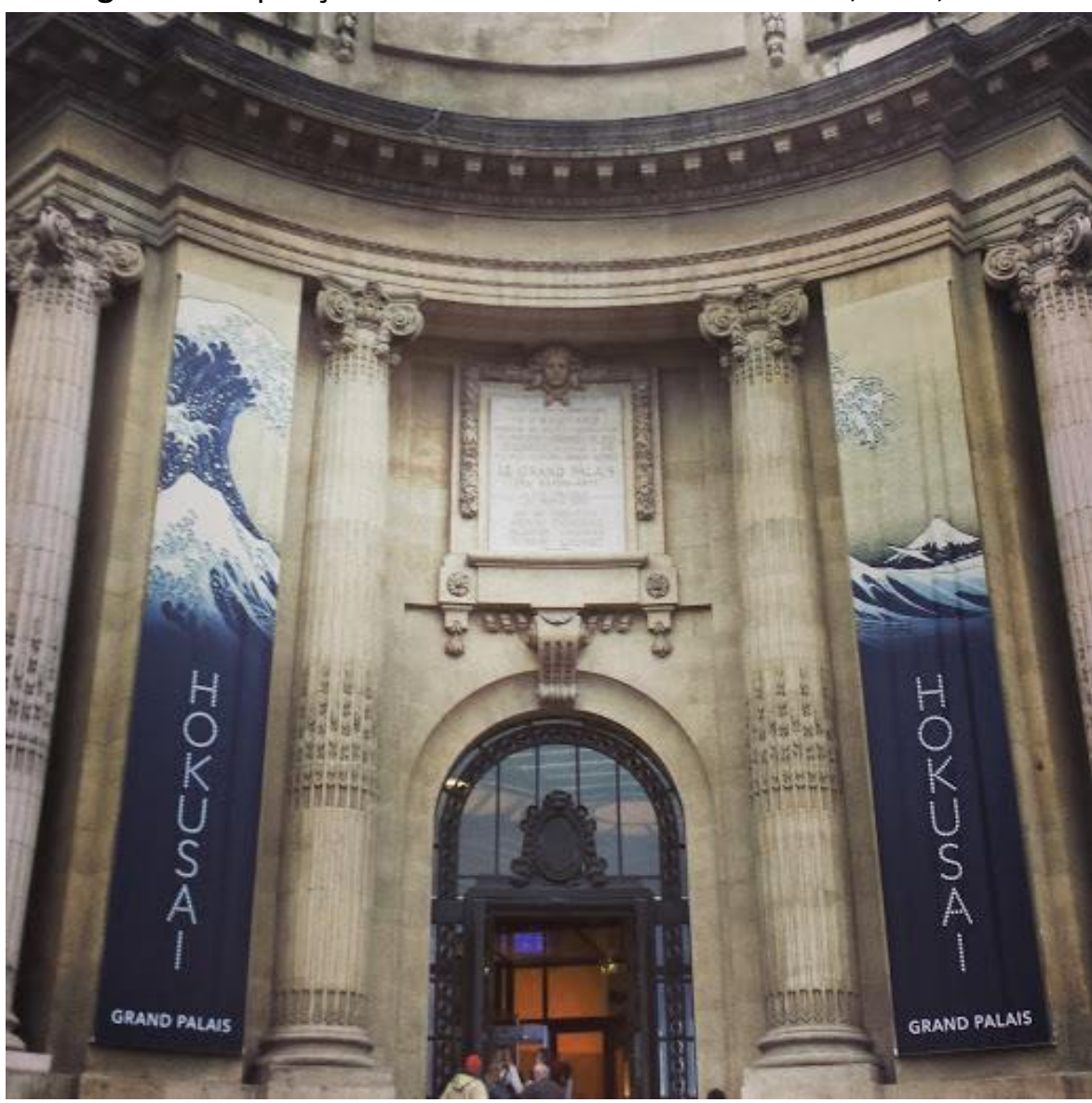

Fonte: http://www.grandpalais.fr/fr/evenement/hokusai

Não sem razão, as gravuras de Hokusai, que se mostraram extremamente populares no Japão e fora dele, pavimentaram, consequentemente, o caminho para o surgimento de mais séries paisagísticas em sua época.

Uma dessas séries é a de seu contemporâneo Andô Hiroshige, denominada As Cinquenta e Três Estações da Tōkaidō. Apesar de sua carreira prolífica, Hiroshige alcança o pico de seu sucesso ao imortalizar a famosa rota entre Edo e Quioto, na qual produz inúmeros 
esboços ao longo dos 500 quilômetros de rota que liga essas cidades. Seu trabalho, mesmo não tão inovador como o de Hokusai, teve êxito comercial ainda maior que de seu contemporâneo; marcada pela captura lírica e intimista da experiência da pessoa comum na paisagem japonesa. Com a postura de um comum viajante, ele imortaliza lugares memoráveis em diferentes momentos do dia e em variações climáticas. Para ele, não havia tema vulgar ou que não devesse ser retratado (STRANGE, 1906).

As paisagens de Hiroshige representam o estágio final do desenvolvimento do ukiyo$e, \mathrm{e}$, mais amplamente, da arte tradicional japonesa, pois, o que habitualmente se considera uma tradição clássica no Japão é aquilo que surgiu antes da modernização e da ocidentalização do Japão na Revolução Meiji, em 1868. Nesse entendimento, a imensa produção de Hiroshige, de 5400 gravuras, e de muitor outros, transformaram-se em um imenso legado para muitos artistas (BREUER, 1994).

Em 1854, o Japão foi forçado a dar fim ao seu isolamento, de maneira que se inicia o intercâmbio cultural com a Europa. Toda a sua rica produção artística aqui relatada, e muitas outras, foram expostas subitamente aos olhos europeus. Esse momento coincidiu com o dinâmico período no qual a arte europeia estava sendo questionada, a busca por novas inspirações era constante, de forma que foi inevitável o surgimento da grande comoção principalmente entre os artistas progressistas. 


\section{O INTERCÂMBIO CULTURAL - A GRANDE ONDA}

\subsection{O CONTEXTO EUROPEU}

As mudanças sociais que ocorreram durante o período Edo foram semelhantes às que estavam acontecendo na Europa no século XIX: crescente urbanização, estabelecimento de uma economia monetária e, acima de tudo, ascensão da classe média. Se a arte é o reflexo do comportamento social de uma determinada época, inicia-se aqui cenário histórico do Impressionismo a partir das duas coordenadas com as quais a História trabalha: o espaço e o tempo.

A França do século XIX estrutura-se e adquire significado a partir do fenômeno histórico e socioeconômico que se desenvolveu na Inglaterra no século XVIII e que, posteriormente, repercute no mundo inteiro: o fenômeno da Revolução Industrial. Esse modelo de desenvolvimento econômico, fomentado pelo espírito capitalista reinante, significou o verdadeiro rompimento do "modus vivendi" do passado, marcado por brutais transformações econômico-sociais devido à inserção de tecnologia nos sistemas de produção fabril (MURGUIA, 1999).

De acordo com Hauser (2005), a França oitocentista é marcada por movimentos liberais, cuja ordem social e econômica se delimita em conjunto com a Revolução Industrial. Nesse contexto, a aristocracia se extingue do cenário dos eventos históricos e se recolhe a uma existência puramente privada em virtude da supremacia da nova classe social em plena posse de conscientização do poder: a burguesia.

Aquino $(2008$, p. 6) acrescenta que, a Revolução Industrial é também "a revolução da concepção do tempo", pois este, antes ditado pelo ritmo marcado pelos fenômenos da natureza, passa a ser vinculado e estruturado à produção do trabalho fabril, rápido e antinatural. A velocidade, a potência, o progresso e a inovação passam, portanto, a tecer o novo contexto percebido em todas as áreas da sociedade.

A energia que movimentada as maquinas era, antes, derivada de fontes animal e humana. Na revolução tecnológica de processo produtivo, a matriz energética passou a ser extraída de fontes inanimadas. Foi uma mudança radical que revolucionou não só o tempo, 
mas, consequentemente, a relação que o homem possuía com os objetos e com a vida social. Hauser afirma (2005, p. 176): “A substituição contínua e cada vez mais rápida de artigos de uso diário por novos conduz a uma diminuição do afeto pelo material e também pela posse intelectual".

É no contexto dessas inter-relações que Gombrich (1993) considera que a Revolução Industrial ajudou a destruir as tradições do sólido artesanato, fazendo que o mesmo entre em crise, pois o ofício artístico, no momento em que o trabalho manual perde seu lugar à produção mecânica, torna-se apartado da produção. Essa ruptura engendrou uma verdadeira reinvenção da arte, pois, se a técnica libera a criação, o artista, por consequência, se torna responsável e senhor de seu projeto criativo. Como afirmou o filósofo alemão Walter Benjamin (1892-1940) "[...] a intelectualidade parte para o mercado" (BENJAMIN, 2009, p. 38).

Gombrich (1993), acima citado, avalia que, nesse particular contexto de mudanças, alguns artistas marginalizados, familiarizados com o avanço industrial, científico e tecnológico, sentiam-se cada vez mais descontentes e inconformados com as finalidades e os métodos oficiais que agradavam o público. Eles desejavam não mais seguir as estáticas e conservadoras regras de composição helênica, nem produzir obras baseadas na mitologia, iconografia religiosa ou na Antiguidade Clássica em um estilo idealizado; porém, incentivavam entre si o desenvolvimento de um estilo totalmente pessoal.

Para eles, a pintura de tradição renascentista, por sua vez, havia se tornado ao longo dos séculos um repertório vazio e oco de preceitos rígidos que, longe de representar as coisas tal como eram, representava meras fantasias. Esses jovens queriam acompanhar e pertencer ao próprio tempo e representar suas próprias observações, a mutabilidade, o ritmo nervoso, as impressões intensas e efêmeras da vida na cidade. Foi uma batalha muito semelhante ao que o Japão enfrentou dois séculos antes, deu a indicar que essas duas diferentes culturas têm mais em comum do que parece à primeira vista.

A tecnologia moderna, que introduziu um dinamismo sem precedentes em toda atitude perante a vida, fez com que esses artistas percebessem que a velocidade deveria pertencer, portanto, à essência. Foi inevitável, assim como foi no período Edo, que novas temáticas artísticas surgissem em conjunto com novas técnicas. 
A busca por reproduzir com precisão os fugazes efeitos de luz que viam diante dos próprios olhos resultou em pinceladas individuais bem visíveis sobre a superfície pictórica, que se tornam urgentes, toscas, imprecisas e enérgicas, representando o espírito do momento. Não interessava mais - e nem havia tempo - em reproduzir minuciosamente as gradações de luz em um estúdio fechado. "A tinta, pela primeira vez, tornava-se um meio cujas propriedades estavam sendo celebradas ao invés de disfarçadas atrás do artificio de uma ilusão pictórica" (GOMPERTZ, 2013, p. 464).

Sanchez e Almarza (2008), a esse respeito, acrescentam que o diferente caminho adotado pelos impressionistas em relação à técnica, solapou as exigências do acabamento terso que dominava a tradição neoclássica da pintura francesa. Murguia (1999, p. 40) confirma:

O Impressionismo reuniu artistas insatisfeitos com o academicismo estético. E a história deste movimento mostra, a cada momento, as lutas por eles travadas com os representantes da pintura acadêmica em prol de uma pintura realista que substituísse o idealismo tradicional. [...] (Os impressionistas) obedeceram, em última instância, a procura de uma nova arte, mais solta e natural. Ou seja, uma arte não tradicional, não acadêmica, não circunscrita à sala de desenho: uma arte moderna.

O conceito de modernidade, que não se define apenas pelo tempo presente, mas por toda uma nova atitude e consciência, foi preconizava por reflexões derivadas de CharlesPierre Baudelaire (1821-1867), poeta, escritor e crítico de arte francês que causou profundo impacto entre os impressionistas. Ao observar as mudanças que surgiam a partir da modernização da vida urbana parisiense, Baudelaire insistia que a arte do presente não deveria focar-se no passado, mas, sim, se valer do senso de atualidade para representar a vida presente. Ele defendia que, para que qualquer modernidade algum dia fosse digna de poder ocupar o posto de "antiga", era preciso extrair o eterno no transitório, o poético que pode conter no histórico. Em seu ensaio O Pintor da Vida Moderna, de 1863, Baudelaire aludia especificamente ao problema do tema da pintura, o qual ele soube relacionar à moda. Para ele, caberia ao pintor moderno, já que este representa temas universais, deixar de vestir os personagens segundo a moda clássica da Antiguidade ou da Renascença e, sim, de acordo com a sua própria época. Suas próprias palavras: 
A modernidade é o transitório, o fugitivo, o contingente, a metade da arte, cuja outra metade é o eterno e o imutável. Existiu uma modernidade para cada pintor antigo [...]. Não temos o direito de desprezar ou de prescindir desse elemento transitório, fugidio, cujas metamorfoses são tão frequentes. Suprimindo-os, caímos forçosamente no vazio de uma beleza abstrata e indefinível [...] (BAUDELAIRE, 1995, p. 860)

Baudelare afirmava, portanto, que os temas dos pintores deviam ser obrigatoriamente extraídos da modernidade.

Freitas (2005) sustenta que a busca dessa autonomia em relação ao ambiente social externo, realizado por Édouard Manet (1832-1883), Gustave Courbet (1819-1877) e pelos impressionistas, transtorna e confunde as estruturas mentais, de modo a explicar as violentas reações da crítica que, como resultado, indicam uma revolução por excelência.

A desaprovação pela Academia de Belas Artes era prevista, uma vez que essa instituição, segundo Gompertz (2013, p. 492), “cumpria de maneira admirável seu dever de proteger a rica herança estética do país", que, por sinal, se estendia ao comércio.

Acontece que, em uma sociedade regida pelas leis de mercado, nos quais os bens são tão somente para o consumo, a arte também não poderia escapar do seu valor de mercadoria. De acordo com Murguia (1999), o ofício artístico era encarado também como um negócio, de forma que, em decorrência, se desenvolveu uma profunda brecha no século XIX. Gombrich (1993) explica que, de um lado, estavam os artistas cujas conviç̧ões só Ihes permitiam obedecer às convenções tradicionais; do outro, aqueles que se orgulhavam de seu isolamento autodeterminado. Em suma, uma brecha entre aqueles que se fixaram na falsa segurança da arte oficial e os que, movidos por um ideal de modernidade, não se deixaram bloquear por uma instituição artística e optaram pelo livre e abstrato mercado, amparados inicialmente apenas por marchands independentes, a destacar Paul Durand-Ruel (1831-1917) (GOMPERTZ, 2013).

É importante mencionar que a maior parte dos pintores ditos progressistas vinha de famílias de boa posição econômica. A origem familiar de personagens como Édouard Manet, acima referido, Edgar Degas (1834-1917), Paul Cézanne (1839-1906), entre outros, permitia que exercessem suas profissões sem ter que se preocupar com seu sustento. Salvo casos como Claude Monet (1840-1926) e Pierre-Auguste Renoir (1841-1919), que precisavam viver do próprio trabalho, ou seja, da venda de suas obras; poderiam, desse modo, ser enquadrados 
justamente nessa sociedade em que a obra de arte era mercadoria (MURGUIA, 1999). Por evidente, o Impressionismo, assim como a escola ukiyo-e foram, portanto, movimentos essencialmente burgueses.

Nesse contexto, ainda segundo Gombrich (1993), é a primeira vez que a arte se torna um perfeito veículo de expressão da individualidade. Ele afirma que:

a palavra Arte adquiriu para nós um significado diferente. E que a história da arte no século XIX nunca venha a ser a história dos mestres de maior êxito e mais bem pagos desse período. Vemo-la antes como a história de um punhado de homens solitários que tiveram a coragem e a persistência de pensarem por si mesmos, de examinarem convenções sem temor e em termos críticos, e criaram assim novas possibilidades para a arte (GOMBRICH, 1993, p. 399).

De acordo com Gompertz (2013, p. 486), os impressionistas escolheram bem o seu momento. "Todos os ingredientes necessários para uma ruptura com a tradição estavam reunidos na Paris pós-revolucionária: mudança política violenta, rápidos avanços tecnológicos, a emergência da fotografia, novas e estimulantes ideias filosóficas". O Japão, que coincidentemente se apresenta nesse momento, se fez presente na jornada que seria definida por esses inovadores artistas.

\subsubsection{A propagação do Japão na Europa}

Em seus estudos sobre o Japonismo no Ocidente, Wichmann (2007) afirma que o Japão influenciou mais profundamente a Europa em relação a qualquer outra nação. E cita como exemplo a China, que, no fenômeno conhecido como chinoiserie (moda chinesa na Europa) dos séculos anteriores que não penetrou na sociedade ocidental na mesma intensidade, apesar de ser atribuído a ela o título de mentora do Japão.

Essa afirmação se deve ao fato de que o contato com o Japão coincidiu com o período de questionamento e negação da tradição, como visto no item anterior. Com efeito, os artistas franceses, já ávidos por encontrar processos originais e os chamados "frissons nouveaux", buscam a solução na cultura do outrem, que, por isso, passa a oferecer a resposta a tal questionamento. Daí porque o Japonismo não se restringiu a um pequeno grupo de conhecedores e artistas, mas também contaminou a população de modo geral. 
A esse respeito, Lima (2011, p. 5) ressalta que a disseminação das artes e ofícios japoneses na Europa ao grande público aconteceu principalmente por intermédio das Exposições Internacionais, eventos esses que nada mais eram do que o reflexo das mudanças sociais e "do culto à mercadoria" que se passavam no Velho Continente.

O Japão, pela primeira vez após a abertura de seus portos, faz sua estreia na Exposição Universal com sede em Londres, em 1862 e, logo depois, em Paris, em 1867. O objetivo dessas exposições era mostrar a força e a consolidação do sistema fabril ao grande público e às outras nações. Os avanços técnico-científicos, que antes só se viam nos ambientes das fábricas, em decorrência da revolução do processo produtivo, puderam ser vistos e mostravam as mercadorias frutos do capitalismo triunfante (GOMES; PICCOLO; REY, 2011, p. 2).

Figura 9 - Pavilhão japonês. Exposição Internacional de Londres, 1862

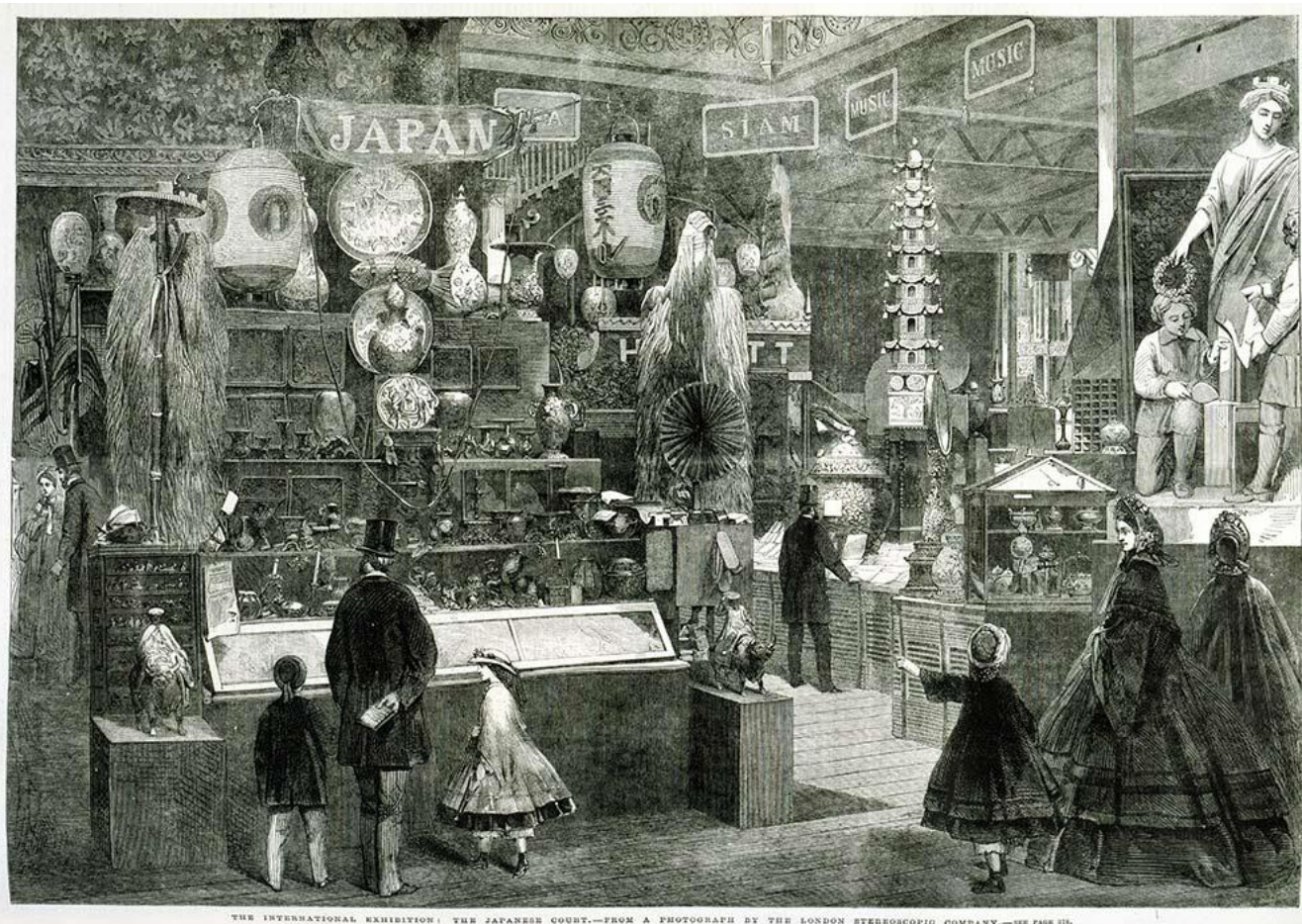

Fonte: http://www.vam.ac.uk/content/articles/j/japanese-cloisonne-in-19th-century-literary-sources

De acordo com Ives (1979), o ineditismo em que levou vasta quantidade de objetos japoneses a ficarem à mostra ao grande público (Figura 9 e Figura 10) - ao contrário da representação apenas por palavras e imagens - fez com que os pavilhões japoneses se revelassem um grande sucesso, tanto entre os críticos, que o consideraram como um "paraíso intocado", quanto entre os simples amadores. Devido ao seu exotismo e à produção artística 
totalmente diferenciada, essas exibições não só renovaram a aura de mistério e exotismo sobre o Japão, como o fizeram conquistar prestígio e repercussão internacional imediata. Daí porque Okano (2013, p. 3874) explica que "Era necessário corresponder à expectativa estrangeira bem como assegurar a dignidade nacional ao conquistar um status de qualificação e nível de igualdade no campo artístico".

De acordo com Santos (2013), somente a Exposição de Paris de 1867 recebeu cerca de 11 milhões de visitantes, sendo que, nessa época, a moda japonesa já estava alastrada fora dos limites dessa exposição.

Figura 10 - Objetos japoneses expostos na Exposição Internacional de Paris de 1867

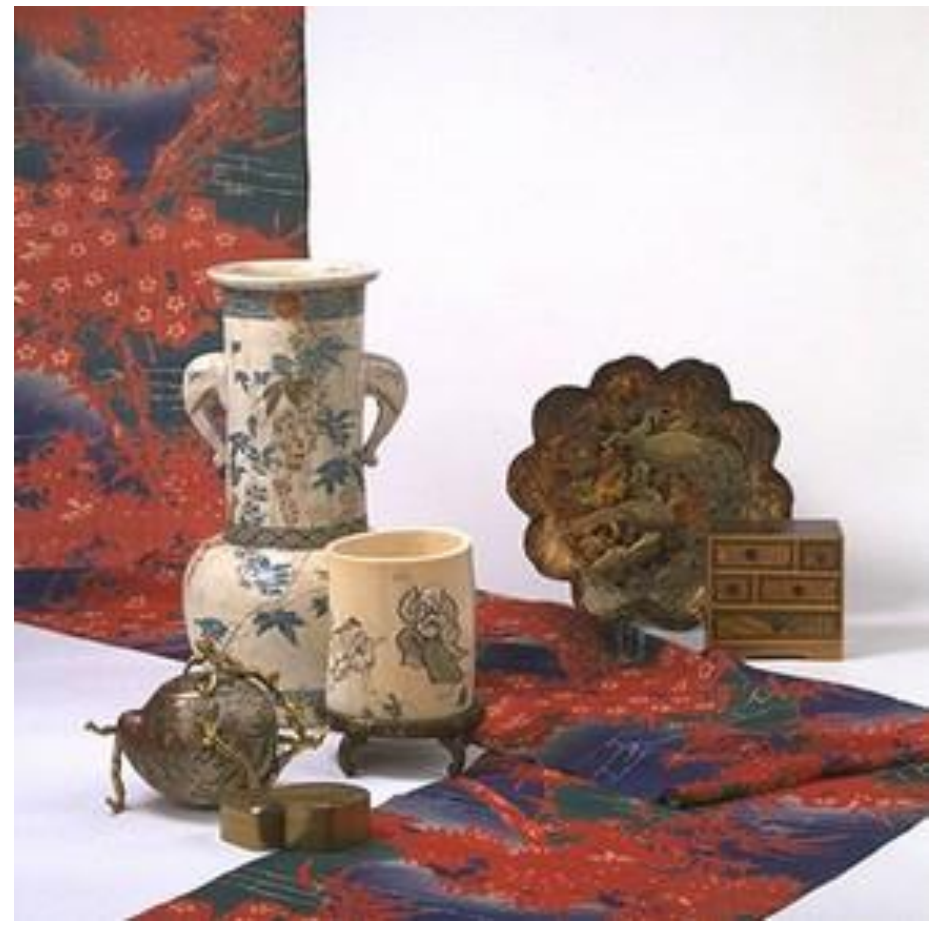

Fonte: http://www.vam.ac.uk/content/articles/t/the-victorian-vision-of-china-and-japan

Ao apresentar sua produção maravilhosamente complexa, o Japão logo passou a ser admirado artisticamente, de modo que continuou a participar de todas as Exposições Internacionais subsequentes. O fascínio europeu sobre esses artefatos, que pareciam ainda mais requintados vistos pelos olhos de um público cansado do mau gosto das mercadorias produzidas em massa pela revolução industrial, se fortaleceu. Esse foi o motivo que levou Okano (2010) ao dizer que também trouxe como consequência a valorização da arte aplicada no Ocidente, visto que as obras japonesas apresentadas foram predominantemente 
consideradas como legítimas obras de arte - como já mencionadas em itens anteriores resultantes de sua alta qualidade e tradição (V\&A, 2014).

Edmond de Goncourt (1822-1896), citado por Siegfried Wichmann, crítico artístico e literário francês, em 1877, registra essa repercussão:

É estranho, essa revolução trazida pela arte japonesa entre pessoas que, em matéria de arte, são escravos da simetria grega e que, de repente, se apaixonam por um prato no qual as flores não estão posicionadas no centro, e por um tecido em que a harmonia é alcançada não através da gradação de tonalidades, mas pela justaposição de cores cruas (WICHMANN, 2007, p. 32).

Mais que simplesmente atraírem pelo seu exotismo e pela perfeição técnica, os artefatos japoneses, ao apresentaram ideias e aspectos composicionais inesperados e não convencionais, ajudaram os artistas europeus a refletirem até que ponto as convenções artísticas tradicionais, utilizadas desde o Renascimento, ainda estavam inconscientemente enraizadas entre eles.

Apesar dos inúmeros objetos que chegaram à Europa, como porcelanas, cerâmica artesanal, laca, leques, sedas e bambu, foi justamente a gravura ukiyo-e que exerceu enorme encanto junto aos europeus e foram colecionados em profusão. Apesar de não se configurar como arte tradicional, já que era fruto da manifestação dos citadinos da Era Edo e por estar em decadência no próprio país - utilizada como embalagem - foi proclamada como obra representativa do Japão pelo Ocidente. Okano (2013, p. 387) esclarece:

Com a abertura das suas portas para o Ocidente, o Japão reconheceu a necessidade de marcar a sua própria imagem, que deveria ser peculiarmente japonesa, isto é, diferente da arte chinesa. A seleção de tais imagens foi realizada no processo de mão dupla, não apenas pelos próprios japoneses, mas também pelos ocidentais que ditavam, como vimos, a sua preferência. Ukiyo-e encaixava-se exatamente num modelo de arte que satisfazia tanto o Japão quanto o Ocidente, pois se tratava de um produto de exportação essencialmente japonês, de fácil transporte e de preços acessíveis, o que facilitava o comércio desse tipo de obra, que traz em si o exotismo de uma terra longínqua. 
Percebe-se, pois, que o olhar estrangeiro atribuiu a essa arte popular um valor que ela não possuía em seu próprio país e a elevou no âmbito da arte, tornando-a objeto de entusiasmado estudo.

A apreciação das gravuras japonesas no Ocidente aconteceu no século XIX não apenas devido à sua ubiquidade e nem porque eram desconhecidas anteriormente, mas aconteceu porque, nesse período, ocorreu a mudança de conceito da arte, de forma que o ukiyo-e poderia ser mais valorizado do que meros objetos de curiosidade (NASH, 2004, p. 11).

Okano (2010, p. 374) afirma que "o deslocamento de um elemento cultural para um território estrangeiro cria modelizações que modificam o sentido original desse elemento e gera novos significados" e salienta que essas gravuras alcançaram reputação como objeto artístico principalmente entre os franceses, que não conheciam o Japão, o que gerou, além do grande entusiasmo, a visão idealizada do seu país de origem. Essa mesma autora ainda afirma que:

o processo de encontro de elementos díspares pode acarretar e evidencia a produção de novos sentidos que se apresenta pelo deslocamento ocorrido, porque toda vez que muda o contexto, o signo tece relações diferenciadas e como consequência, sofre modificações. Há, desse modo, a geração de novos sentidos que enriquecem a cultura que recebe a influência de uma outra distinta, com quem perfaz um diálogo (OKANO, 2010, p. 379).

Bakhtin (2003) acrescenta que, no campo da cultura, a distância é a alavanca mais poderosa para a compreensão, pois a cultura do outro só se revela com completude aos olhos de outra cultura

Colocamos para a cultura do outro novas questões que ela mesma não se colocava; nela procuramos respostas e essas questões, e a cultura do outro nos responde, revelando-nos seus novos aspectos, novas profundidades de sentido. Sem levantar nossas questões não podemos compreender nada do outro de modo criativo (BAKHTIN, 2003, p. 366)

A recepção de uma influência não é passiva; ela é compreendida à distância, de modo que, uma vez respaldada pela sua própria cultura, é capaz de olhar para o outro de forma criativa. Do contrário, residiria apenas na dublagem e na cópia vazia. Nesse sentido, a 
influência nipônica na Europa está longe de ser a imitação do Japão; mesmo porque, o Japão imaginado pelo Ocidente estava distante da realidade; mesmo assim, configurou-se como a reinvenção originada do diálogo bilateral entre duas culturas distintas que resultou principalmente na expressão da própria individualidade, na criação de "novas maneiras de ver". Bakhtin (2003) sustenta que o encontro de duas culturas não tem como resultado a renúncia de si mesma; pelo contrário. Esse encontro promove a conservação de sua unidade e sua totalidade, sendo que a experiência acaba por enriquecer ambas mutualmente.

De acordo com Ives (1998) e com Breuer (1994), tudo indica que o primeiro encontro entre os artistas europeus e as gravuras ukiyo-e aconteceu em 1856 pelo famoso editor de Paris Auguste Delâtre (1822-1907), no qual esboços de Hokusai foram descobertos como embrulho de porcelanas. Ele mostrou a seu amigo Félix Bracquemond (1833-1914) que, também entusiasmado com a descoberta, acabou por difundir entre outros artistas de seu círculo, entre eles Édouard Manet, Edgar Degas e James McNeil Whistler (1834-1903). Esse grupo de artistas, por intermédio das gravuras ukiyo-e "descobriram aí uma tradição não contaminada pelas regras e clichês acadêmicos que os pintores franceses se empenhavam em eliminar" (GOMBRICH, 1993, p. 417).

Não muito tempo depois, as gravuras japonesas eram suficientemente admiradas, de modo que eram encontradas com facilidade em lojas especializadas em importação parisienses como, por exemplo as lojas Mme Desoye e La Porte Chinoise (TINTEROW; LOYRETTE, 1994). Ao mesmo tempo, cultiva-se o interesse entre os artistas em colecionar, além de gravuras, outros artigos como quimonos, porcelanas, biombos, e todos os tipos de artefatos representativos japoneses.

Em 1867, pouco tempo depois da referida Exposição Internacional, funda-se em Paris a sociedade denominada Jinglar, um clube secreto dedicado ao estudo e à discussão do Japão e de sua cultura. Este exercício intelectual emprestou ainda mais credibilidade à aceitação do ukiyo-e como arte e não como mera lembrança de viagem. Um dos seus membros, o crítico de arte Philippe Burty (1850-1890), cunha o termo "Japonismo" para descrever exatamente esse novo campo de estudo, a influência nipônica na arte francesa. Breuer (1994) destaca a importância desses clubes, círculos de amizade e encontros entre artistas na disseminação do conhecimento sobre a arte japonesa na França. Porém, se o Japonismo se estabeleceu como uma moda, os artistas representavam apenas um elo - apesar de primordial - de uma rede 
bem mais vasta. Essa rede, segundo Seiji (2014), era composta também por críticos de arte, por colecionadores e comerciantes, o quais, por um processo inconsciente e pelo caráter de novidade, foram ágeis em incitar e perpetuar o gosto pela arte japonesa também entre o público em geral.

De acordo com Nash (2004), as discussões acerca do Japonismo resultaram na publicação de artigos e periódicos, fundamentais na divulgação mais ampla e profunda da arte recém-chegada do Japão.

É nesse cenário que, em 1882, Theodore Duret (1838-1927) publica um artigo com o título L'art Japonais, o mesmo do panfleto de Ernest Chasneau (1833-1921) lançado em 1889. Louis Gonse (1846-1921), redator da revista Gazette des Beaux-Arts, em 1886, publica dois volumes intitulado L'Art Japonais (Figura 11), a primeira a analisar a arte japonesa considerando os princípios de design e cor. O crítico de arte, Zacharie Astruc (1833-1907), escreveu vários artigos para o jornal L'Etendard sobre o mesmo assunto, um dos primeiros a ser veiculado na imprensa francesa. Em 1890, era possível encontrar a biografia de Utamaro e, pouco tempo depois, a de Hokusai, ambos publicados pelo referido escritor francês Edmond de Goncourt (SAVORNIN, 2008). Esse entusiasmo pela novidade e o interesse genuíno por tudo que se relacionava ao Japão - reação que não é difícil compreender - foram as ferramentas mais importante na disseminação e perpetuação do Japonismo. 
Figura 11 - L'Art Japonais, 1886

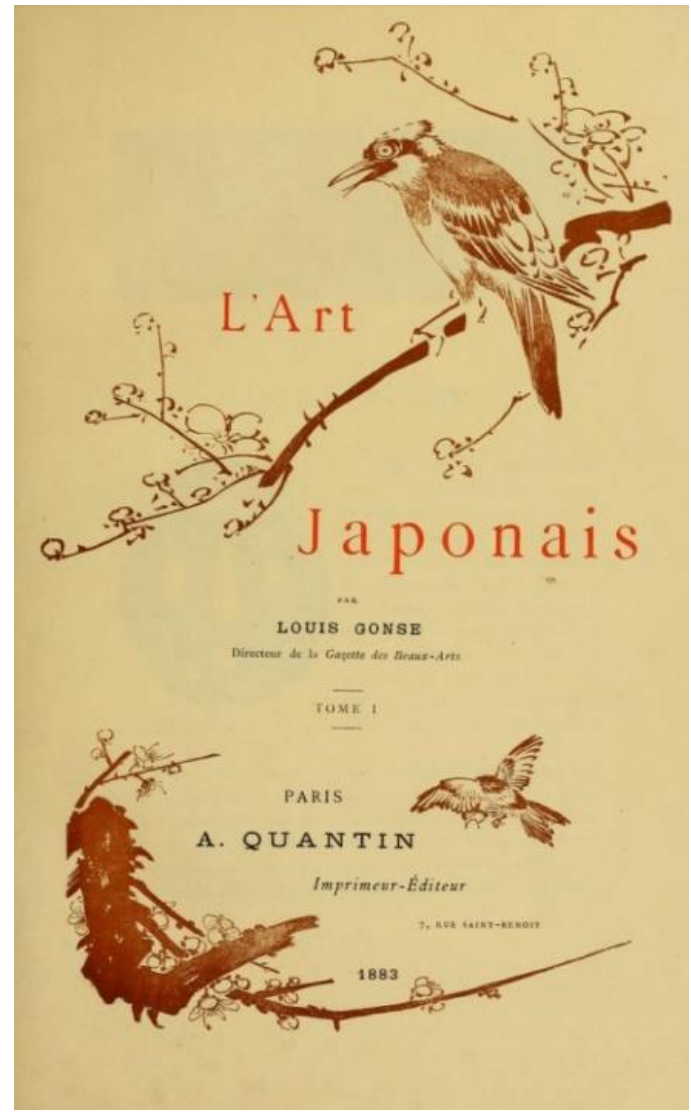

Fonte: http://cs.nga.gov.au/Detail-LRG.cfm?IMG=127335_c\&IRN=127335\&vID=3

Outro personagem que deve ser destacado como imprescindível na propagação do Japonismo é o comerciante Siegfried Bing (1833-1905), também conhecido como Samuel Bing. De origem alemã, mudou-se para Paris um ano após a abertura dos portos japoneses, em 1854, para ajudar seu pai a dirigir a companhia familiar de importação e exportação e lá permaneceu até a sua morte. Aberto a novas ideias, Bing rapidamente percebe o potencial oferecido pela introdução da arte asiática no Ocidente; desse modo, então, se afasta da produção de cerâmica, uma de suas principais atividades, para se envolver no comércio de objetos de arte do Extremo Oriente (WEISBERG; BECKER; POSSÉMÉ, 2006). 
Figura 12 - Siegfried Bing (à esquerda) em cerimônia do chá

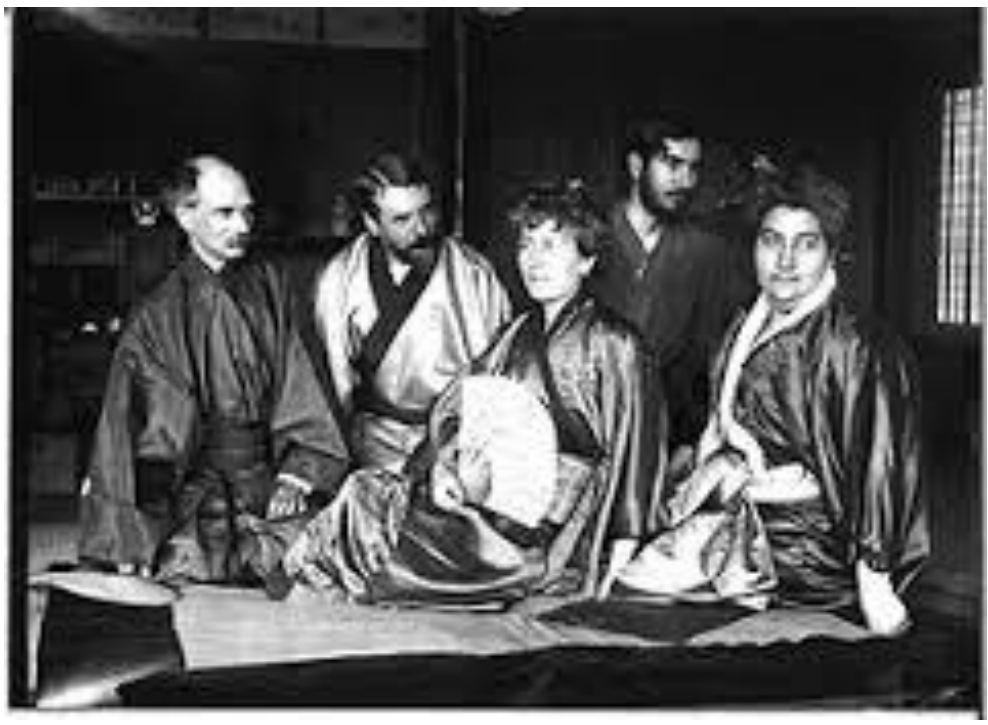

Fonte: https://aboutartnouveau.wordpress.com

A partir do seu afastamento da arte cerâmica, Bing passa a colecionar e comercializar objetos de arte nipônicos e outros em suas galerias na Rua Chauchat e, em seguida, na Rua de Provence, ambas em Paris. Ao associar seu fascínio pela arte japonesa à sua habilidade comercial, não tardou a que seu nome emergisse como referência no campo do Japonismo. Suas viagens ao Japão estreitaram sua relação comercial, de modo que forneceu uma grande gama de gravuras e objetos japoneses a clientes que iam desde colecionadores particulares a grandes museus como o londrino Kensington, atual Museu Victoria \& Albert. Nesse sentido, estudos de Weisberg, Becker e Possémé (2006) confirmam que, devido a atuação de Siegfried Bing, ele ajudou a promover um mercado de arte global.

Em maio de 1888, Bing promove uma exposição de gravuras ukiyo-e em sua loja. No mesmo mês, publica um periódico dedicado exclusivamente à cultura visual japonesa, destinado aos artistas, colecionadores e, mais amplamente, aos amadores. Com publicação mensal, o Le Japon Artistique (O Japão Artístico) (Figura 13), por ter sido traduzido em alemão e em inglês, foi fundamental para que o Japonismo atingisse um público amplo, muito além dos limites franceses. De acordo com Simons (2010), a edição inglesa Artistic Japan (Figura 14), por exemplo, ademais de ter se difundido pela Grã-Bretanha, também chegou aos Estados Unidos. 
Figura 13 - Edição 14 da publicação Le Japon Artistique

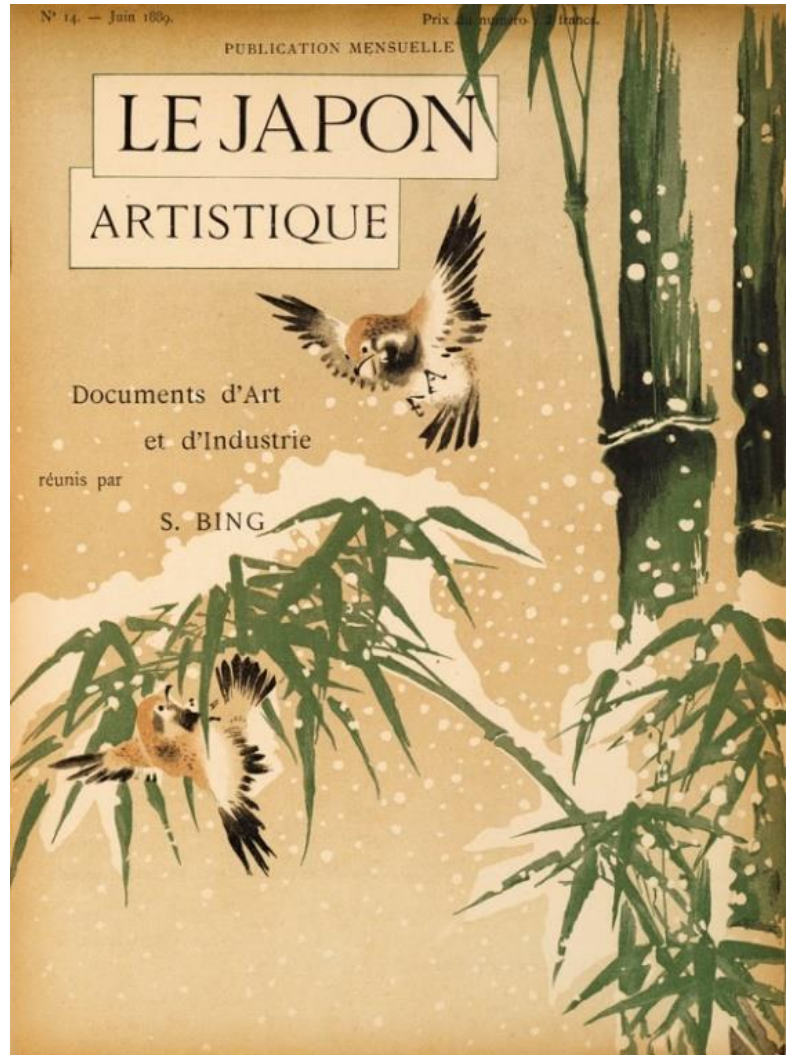

Fonte: http://gallica.bnf.fr

Figura 14 - Versões alemã e inglesa da publicação Le Japon Artistique

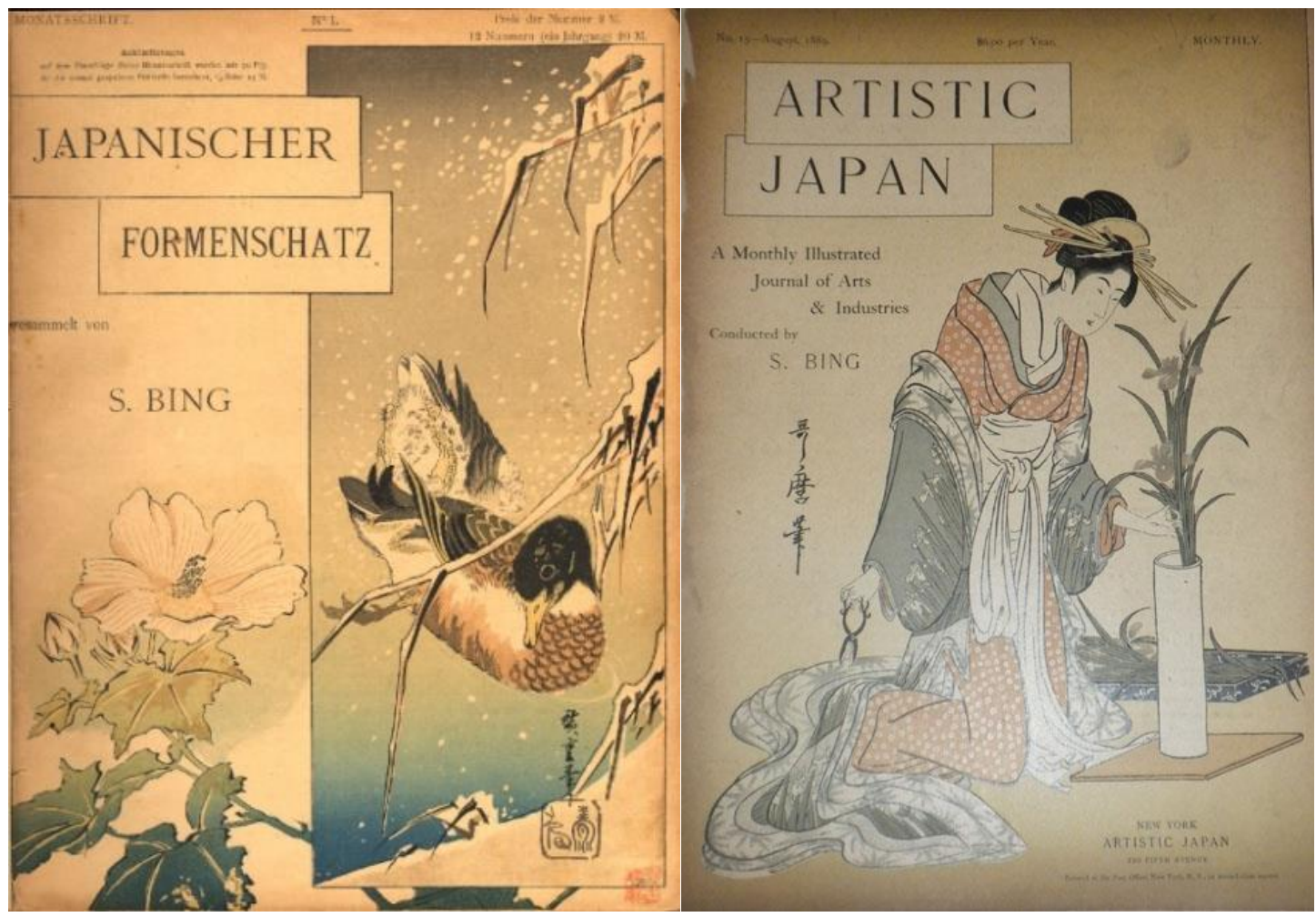

Fonte: http://gallica.bnf.fr 
Os acima citados Weisberg, Becker e Possémé (2006, p. 25) afirmam que "esta publicação se revelou determinante para o Japonismo ao permitir que leitores de todo o mundo percebam como os objetos japoneses são, ao mesmo tempo, belos e abundantes, sendo, portanto, um investimento interessante".

O empenho de Bing em publicar esse periódico indica sua plena consciência do papel da arte japonesa na arte francesa. Em seu artigo introdutório para a primeira edição do Le Japon Artistique, ele declara, segundo Leavens (2009, p. 32): “Esta arte (do Japão) é pessoalmente indissociável com a nossa. É como uma gota de sangue misturada ao nosso sangue, de forma que nenhum poder sobre a terra é capaz de separá-la novamente".

Siegfried Bing é comumente referido como patrono das artes, sua paixão pela arte japonesa o levou a promovê-la de diversas formas. A título de exemplo, em 1890, coordena a maior exposição de gravuras ukiyo-e daquele período, na Escola Nacional de Belas Artes de Paris (Figura 15). A notória exibição expunha 763 xilogravuras, incluindo obras de Utamaro, Hiroshige e Hokusai (WEINBERG, 2003).

Figura 15 - Exposição de Gravuras Japonesas

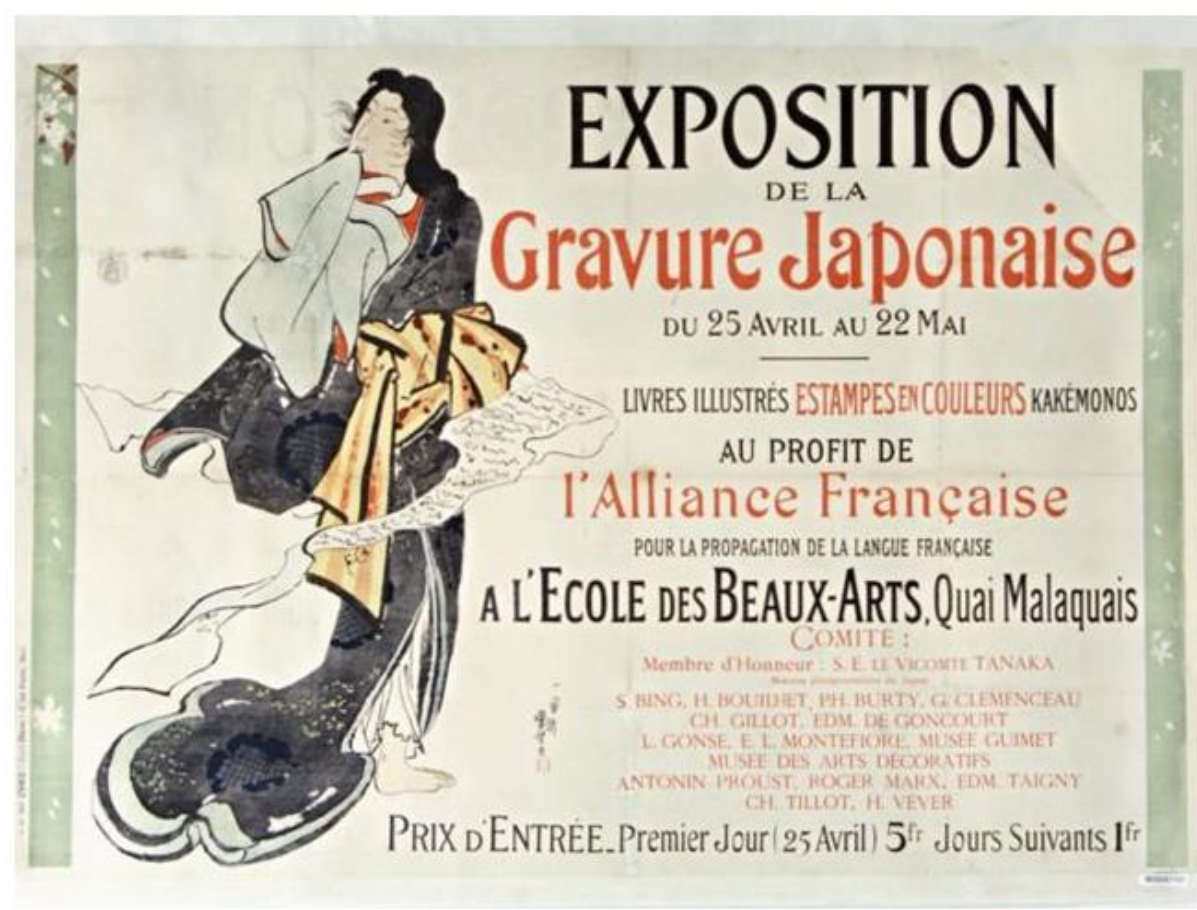

Fonte: http://gallica.bnf.fr 
Bing tornou-se um verdadeiro embaixador na propagação do Japonismo, razão para o testemunho de Gompertz (2013, p. 26), “Hoje, Siegfried Bing é reconhecido como um empreendedor brilhante de muitos talentos, que fez da arte japonesa um componente essencial na produção artística do final do século XIX".

Nos itens seguintes será abordado e analisado o resultado das considerações de todo esse contexto no que diz respeito à influência nipônica na produção dos artistas e designers europeus. É importante ter em mente que as possibilidades ocorridas na inovação na pintura a partir desse movimento foram tão férteis que, inclusive dentro do próprio movimento, tornou-se inevitável que novas propostas começassem a ser apontadas.

Desse modo, deve-se esclarecer que o presente trabalho, apesar de focar no período Impressionista, não se limita a esse período devido a impraticabilidade de se delinear com precisão as fronteiras da influência analisada. O processo de absorção e incorporação deriva de conexões subjetivas, internas e progressivas, que conduzem a uma rede de interligações continuamente sujeita a metamorfoses, em sistema disperso, processo esse que, por sua própria natureza, jamais é rígido. Freitas (2005) afirma que “[...] a dimensão artística se desenvolve de acordo com suas próprias leis, o que equivale a sugerir que o processo artístico, de certa forma - seja como juízo, linguagem ou sistema - é um processo autogovernado". Nesse entendimento, então, Okano (2010) confessa que a cultura seria um organismo vivo, dinâmico e ativo; se encontra sempre em movimento e transformação, contaminando e deixando-se ser contaminada.

Apesar de a história ser categorizada por períodos, as denominações das manifestações artísticas, que muitas vezes são cunhadas posteriormente e, em geral, de forma vaga, não são isentas de superposições e inter-relações.

O presente trabalho, que prioriza o final do século XIX e começo do XX, escolhe abordalo em três seções: A temática, que, mesmo dita como não importante no propósito impressionista, significa uma ruptura clara em relação à arte oficial; a composição, o mais notável aspecto, no qual serão abordados os aspectos composicionais mais relevantes na busca da reformulação pictórica impressionista; e, por último, os efeitos estéticos resultantes desse encontro, que se estendem em muitas outras manifestações artísticas. 


\subsection{AS INFLUÊNCIAS PERCEBIDAS - O DESEMBALAR DE UMA CULTURA}

Nós gostamos das pinturas japonesas, sentimos essa influência, todos os impressionistas têm isso em comum.

Carta de Vincent van Gogh para Theo van Gogh Arles, 5 de junho 1888 (RUGER, 2009)

\subsubsection{A temática}

Segundo Gombrich (1993), no instante em que os primeiros sinais do novo movimento começaram a emergir nas obras dos jovens artistas franceses, três estilos variados e, portanto, com variadas ênfases temáticas, coexistiam confortavelmente na pintura europeia do século XIX, apesar de antagônicos.

O Neoclassicismo, centrado na razão e na ordem clara, explorava o renascimento dos ideais através das imagens dos antigos. Inspirava-se na história e mitologia gregas, e defendia que era dever moral do artista pintar temas de elevado caráter, enraizados nas noções da virtude da Antiguidade.

O estilo romântico, por sua vez, no dizer desse mesmo autor, caracterizou-se como o movimento estético mais importante da primeira metade do século XIX. Emergiu como reação à corrente dominante neoclássica; todavia, também privilegiou o idealismo, temas históricos e de caráter narrativo; porém, ao invés de se apoiar no tratamento racional, respalda-se em uma visão de valorização intuitiva e emotiva.

Os artistas românticos almejavam libertar-se das restritas convenções acadêmicas a fim de destacar a individualidade e a subjetividade do artista. Além dos temas exóticos, históricos e heroicos - que eram retratados com grandiosidade e dramaticidade épicas apresentavam ainda acontecimentos recentes, como em a Liberdade Guiando o Povo (1831), em comemoração à Revolução de Julho' do ano anterior, de Eugène Delacroix (1798-1863). A pintura paisagística, de acordo com Sanchez e Almarza (2008), que até então fora considerada um ramo secundário na arte, foi gradualmente adquirindo maior importância, fato esse que refletia as novas atitudes perante a natureza. Sob a influência do filósofo Jean-Jacques

\footnotetext{
${ }^{1}$ A Revolução de Julho de 1830 foi uma rebelião de liberais e revolucionários contra a monarquia francesa e culminou na abdicação de Carlos $X$. Com apoio da burguesia francesa, o trono foi assumido pelo duque Luís Felipe (ENCYCLOPAEDIA BRITANNICA, 2015a).
} 
Rousseau (1712-1778), que ofereceu uma idílica, bucólica imagem do mundo natural em oposição à corrupção e artificialidade da sociedade da época, esses autores afirmam que o uso da paisagem pitoresca se inclina aos efeitos emotivos, na transmissão de sensações e valores interiores; e em seu exemplo mais representativo há as obras do inglês William Turner (1775-1851).

Esse movimento somente veio a perder seu impulso de modo considerável quando, durante a Revolução de $1848^{2}$, surge a visão do presente real e menos emotivo, em oposição frontal tanto aos românticos, quanto ao estilo neoclássico.

Essa oposição toma forma nas mãos de alguns artistas os quais dividem a aspiração de representar o mundo de maneira documental, de mostrar pessoas anônimas em acontecimentos também anônimos. Tal manifestação, que nunca chegou a ser um movimento regular, ficou conhecida como Realismo (GOMBRICH, 1993).

O pintor já referido Gustave Courbet, o qual denominou o movimento, estabeleceu-se como seu principal defensor por desafiar a primazia da pintura de história favorecida pela Escola Nacional de Belas Artes, a academia de arte patrocinada pelo Estado. Ele defendia a sinceridade artística, a verdade real contra "a manipulação hábil de clichês tradicionais". Sustentava que, se a pintura é uma arte concreta em sua essência, ela não pode existir senão nas representações das coisas existentes e tangíveis. "Ele não queria a formosura, queria a verdade" (GOMBRICH, 1993, p. 403).

Essa deliberada determinação e engajamento em representar o mundo tal como o viam, os pintores, encorajavam muitos de seus contemporâneos a rejeitar o convencionalismo e seguir apenas sua própria consciência artística. O objetivo de Courbet, como ele mesmo declarou, era "traduzir os costumes, as ideias, a aparência de minha época de acordo com a minha própria estimativa; não ser somente um pintor, mas um homem também; em uma palavra, para criar arte viva" (LINDSAY, 1973, p. 138), de forma que a ênfase desse movimento, portanto, fixou-se na projeção essencial da personalidade, da autêntica expressão. Devido a esse pensamento, Courbet afirmava que a arte não podia ser ensinada, já que era algo essencialmente individual.

\footnotetext{
${ }^{2}$ A Revolução de 1848 , conhecida também como Revolução de Fevereiro culmina no fim da monarquia Orleans (1830-1848) com a abdicação de Luís Felipe e leva à criação da Segunda República Francesa, que possuía como lema oficial "Liberté, Égalité, Fraternité" (PEARCE, 2011).
} 
Respaldado em suas considerações, pretendia ele que suas pinturas possuíssem caráter social e funcionassem como uma espécie de promoção ou de protesto sobre as convenções de seu tempo. De acordo com Hauser (2005, p. 99)

\begin{abstract}
A pintura de paisagem torna-se uma manifestação contra a cultura da sociedade dominante. A paisagem moderna surgiu desde o início como um contraste com a vida da cidade industrial, é verdade, mas as pinturas de paisagens românticas ainda representavam um universo autônomo, uma imagem irreal, a ideal existência, que não tinham necessidade de serem levadas em qualquer relação direta com a vida do presente e com a vida cotidiana. Este mundo era tão diferente das cenas reais, que a vida contemporânea certamente entendeu-as como sua antítese, mas dificilmente como um protesto. A íntima paisagem da pintura moderna, por outro lado, descreve um ambiente no qual, em sua tranquilidade e intimidade, é totalmente diferente da cidade, mas ao mesmo tempo tão próximo a ele devido ao caráter simples, sem romantismo, que são inevitavelmente atraídos a compará-los.
\end{abstract}

François Millet (1814-1875) possuía um estilo mais conservador do que o de Courbet devido à sua formação acadêmica; todavia, seus temas foram considerados politicamente subversivos. Movido pela injustiça social, em 1857 ele retrata As Respigadoras (Figura 16), que se configurou como revolucionária justamente por retratar a vida da classe trabalhadora como realmente era. De acordo com Gombrich (1993, p. 401), nas academias era preponderante a afirmação de que "pinturas dignas devam representar personagens dignas, e de que trabalhadores e camponeses fornecem temas adequados somente para cenas de genre ${ }^{3 \prime \prime}$. Sanchez e Almarza (2008, p. 63) confirmam esse aspecto:

Ao escolher temas camponeses para a arte, podia-se interpretar uma recusa de temas mais elevados e, portanto, dos valores tradicionais tal e como eram mantidos pelas academias [...]. Dessa forma, o Realismo poderia ser considerado um ataque à civilização e também uma declaração sobre a verdadeira natureza da civilização.

\footnotetext{
${ }^{3}$ Pinturas de genre, ou gênero, fazem referência às representações em estilo sóbrio, realista e comprometido com a descrição de cenas rotineiras (ENCYCLOPÆEDIA BRITANNICA, 2015b).
} 
Figura 16 - As Respigadoras. Jean François Millet, 1857

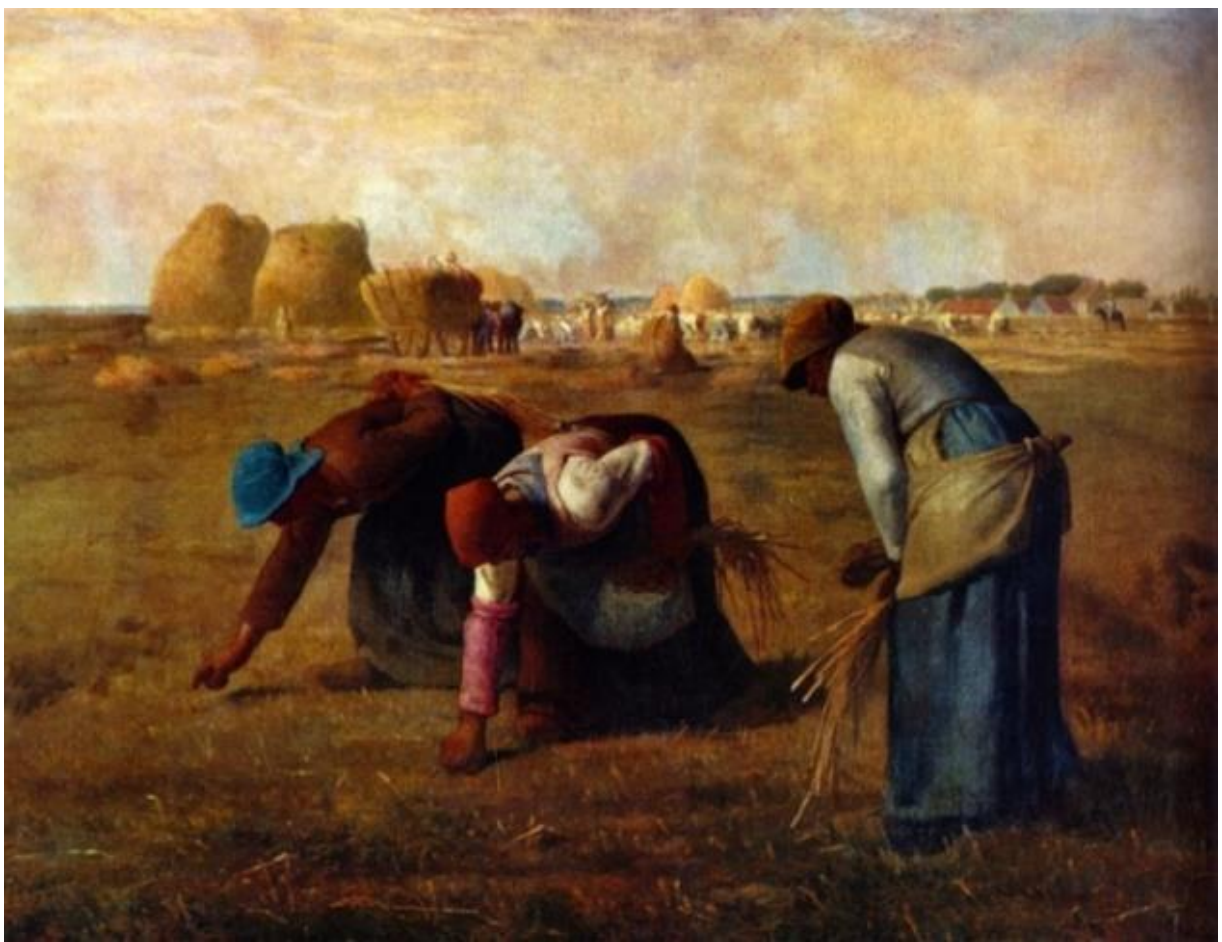

Fonte: http://www.jeanmillet.org

Ainda de acordo com esses mesmos autores, a inovação do Realismo fixou-se majoritariamente na temática; mas alguns pintores, que compartilharam dos propósitos do realismo de Courbet, como Édouard Manet, concluíram que o modo de representar a natureza real como fazia a arte tradicional baseava-se em uma concepção errônea, pois suas condições de trabalho em estúdios fechados eram extremamente artificias. Chegaram à conclusão que não deveriam apoiar-se nas ideias preconcebidas derivadas da academia e, sim, em seus próprios olhos, como é percebido em $O$ Balcão, de Manet. Essas descobertas não foram efetuadas de uma só vez, nem por um só pintor, mas influenciou, entretanto, os precursores do Impressionismo (GOMBRICH, 1993).

A primeira exposição impressionista é datada de 1874; sua história, todavia, se inicia pelo menos nos vinte anos que antecederam. Para Hauser (2005), o Impressionismo representa em alguns aspectos apenas um desenvolvimento lógico, o curso natural da manifestação realista, de forma que a fronteira que os separam é fluida, tornando impossível fazer um recorte histórico e conceitual preciso entre suas fronteiras. Porém, é possível afirmar que o legado mais notório deixado pelos realistas foi, como já defendia Baudelaire em 1863, 
o imaginário da vida moderna que se traduziu em temas extraídos diretamente daquela atualidade.

O Japão, que se apresenta como novidade na França nesse momento de revolução, reflete-se como um aspecto de modernidade de rápida repercussão, como descrito nos subitens 2.1 .2 e 2.2. Desse modo, oferece a esses pintores um renovado estímulo, junto com uma reflexão sobre os costumes da sociedade parisiense que, como a sociedade do período Edo, vivia uma época de busca pelo entretenimento e com possibilidades de lazer acessíveis associados à nova classe social emergente.

Gombrich (1993) enfatiza que os temas escolhidos por esses pintores eram motivo de fúria entre os críticos, tanto quanto a técnica utilizada; com efeito, ainda se esperava que fossem favorecidos os temas "dignos", históricos e dramáticos como ditava a tradição artística francesa estabelecida através de séculos. Porém, os impressionistas foram atraídos pelos temas efêmeros, prazerosos, cotidianos e próximos à realidade humana, temas que Hiroshige, Utamaro, Hokusai e outros artistas do ukiyo-e tinham já desenvolvidos tão fecundamente nos séculos XVII e XVIII, possível somente devido à ascensão de uma nova classe em contexto político e social privilegiado.

O surgimento do novo estrato social em Edo, a burguesia - como abordado nos itens anteriores - proveniente das grandes cidades de inédito contexto pacífico, alinha-se filosoficamente à burguesia francesa do século XIX, pois ambas desenvolvem um modo de vida baseado em preceitos hedonistas, de modo que é fácil perceber o porquê de tais gravuras receberem tanto acolhimento entre os franceses.

A França, recém-republicana e pós-guerra, com a derrubada da monarquia, desfruta nesse período de uma estabilidade social e, como resultado, imerge na cultura do divertimento, de modo que, em 1860, os subúrbios de Paris se fundem à cidade, e os arredores dão lugar aos parques recreativos (KUVATOVA, 2012). A burguesia francesa, satisfeita por não pertencer aum cenário de conflitos, abraça esses locais com avidez e, como consequência, os locais de entretenimento rapidamente se proliferam pela cidade, como teatros, salões de música, cafés, etc. Esse cenário muito se assemelha ao "mundo flutuante" já analisado no presente estudo, mesmo que independentes entre si, pois o ukiyo no Japão e o joie de vivre francês são ambos cenários derivados do florescimento da vida urbana, respaldado pelo modo de vida burguês em sua essência. 
Devido ao seu avanço em dois séculos, o ukiyo-e, mesmo com suas origens humildes, por meio de sua temática do ordinário e dos prazeres, contribui para ampliar o interesse pelos impressionistas na apreciação da vida cotidiana como um tema válido e pertinente a esse momento.

O Realismo e o Impressionismo dividiram alguns aspectos fundamentais; entre eles, a ênfase na realidade espontânea e na individualidade artística; apesar disso, os propósitos eram divergentes. Eles poderiam admirar os trabalhos de Millet ou Courbet, mas nunca escolheriam os mesmos temas. Ao contrário dos realistas, que usaram sua arte como uma denúncia à sociedade, os impressionistas desvinculam-se de quaisquer tons políticos. Mesmo conscientes da estrutura e das divisões sociais, retratavam-nas de maneira objetiva, que deliberadamente evitou qualquer tipo de comentário ideológico (SANCHEZ; ALMARZA, 2008). A realidade que os impressionistas buscavam eram, portanto, mais próximos da realidade retratada nas gravuras japonesas do que de seus contemporâneos próximos: era viva, leve e divertida.

São devido às associações existentes entre os dois períodos, que os escritores e críticos da época, Émile Zola (1840-1902) e os outros acima citados Philippe Burty e Théodore Duret, declaravam que os artistas do ukiyo-e eram "os primeiros e mais perfeitos dos impressionistas" (IVES, 1998).

Ainda segundo Kuvatova (2012), os pintores que focaram a representação de paisagens na Europa no século XIX eram muito mais bem-vindos do que os que possuíam interesse na vida cotidiana; mesmo que os impressionistas não descartassem as paisagens como tema, elas não possuíam muita semelhança com as paisagens Clássicas ou Românticas. Por esse e outros motivos, o Impressionismo configura-se como um movimento extremamente revolucionário.

Alguns autores que se lançam sobre o estudo do Japonismo na arte francesa dividem esse acontecimento em dois momentos:

1. O período de "encantamento", da abertura dos portos japoneses até 1883 , no qual o encontro entre Oriente-Ocidente ampara-se em um nível superficial, representado apenas pela imitação movida pelo exotismo em voga, de modo que 
os levam a citar em suas composições elementos representativos japoneses (leques, quimonos, cerâmica, etc).

2. O período de 1884 até 1914 , de absorção e assimilação criativa dos aspectos japoneses, uma abordagem menos evidente no qual os pintores buscam, na concepção criativa, incorporar os recursos de composição japoneses.

Essa divisão, adotada por alguns autores, não está inserida no presente trabalho, pois, apesar da ocasionalidade da fase de imitação ter de fato acontecido, é possível, mediante uma análise mais profunda, perceber que essa abordagem de representação considerada como superficial, muitas vezes não se configurou simplesmente como o fim; foi, isso sim, tida como método de estudo, muitas vezes complexo e não linear que, posteriormente, atingiu níveis mais profundos na compreensão da arte japonesa. A simples representação de objetos japoneses pôde apresentar, em outros casos, mais que uma simples "inserção de exotismo"; serviu, porém, como uma ferramenta ora de curiosidade, ora de encantamento e, sobretudo, como expressão de seu momento de contemporaneidade. Os propósitos e as motivações de cada artista eram tão particulares que, ao categorizar, torna-se fácil se prender em equívocos.

Um pintor em que o Japonismo se revelou pela da representação de objetos foi James Tissot (1836-1902). Seu entusiasmo pelo País do Sol Nascente não se limitou somente ao viés artístico; mas também o envolveu no pessoal, de modo que o influenciou a incorporar inúmeros elementos representativos japoneses, como em A Japonesa ao Banho, de 1864 (Figura 17). Em Jovens observando objetos japoneses, de 1869 (um dos três quadros com o mesmo título produzidos naquele ano), as duas mulheres que posam expõem os tesouros japoneses de sua coleção particular em sua suntuosa residência (Figura 18). Por sua vez, devido à sua educação em pintura clássica, sua influência foi traduzida apenas pelo uso de elementos representativos; ou seja, não penetrou níveis muito profundos. Apesar disso, ele expõe que a paixão pelo Japão não se limitou aos artistas progressistas, de modo a reiterar o exotismo que marcou seu tempo (SEIJI, 2014). Outro pintor que, semelhante à Tissot, traduziu o japonismo com elementos representativos que estavam constantemente presentes foi o pintor Alfred Stevens, em obras como La Parisienne Japonaise, de 1872. 
Figura 17 - A japonesa ao banho. James Tissot, 1864

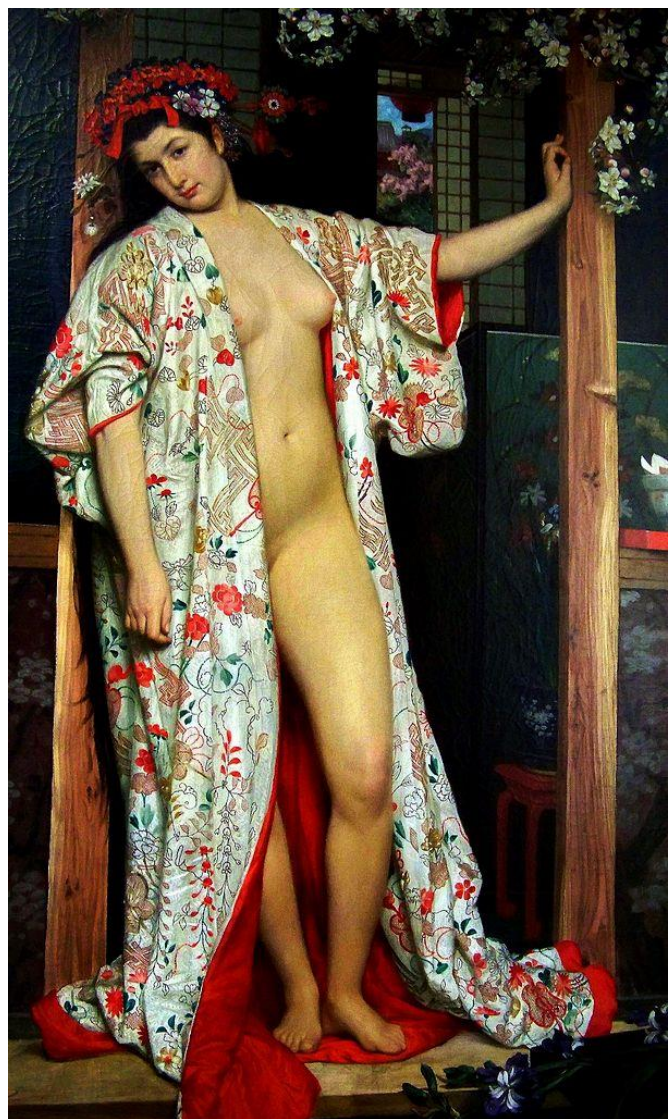

Fonte: http://www.jamestissot.org

Figura 18 - Jovens observando objetos japoneses. James Tissot, 1869

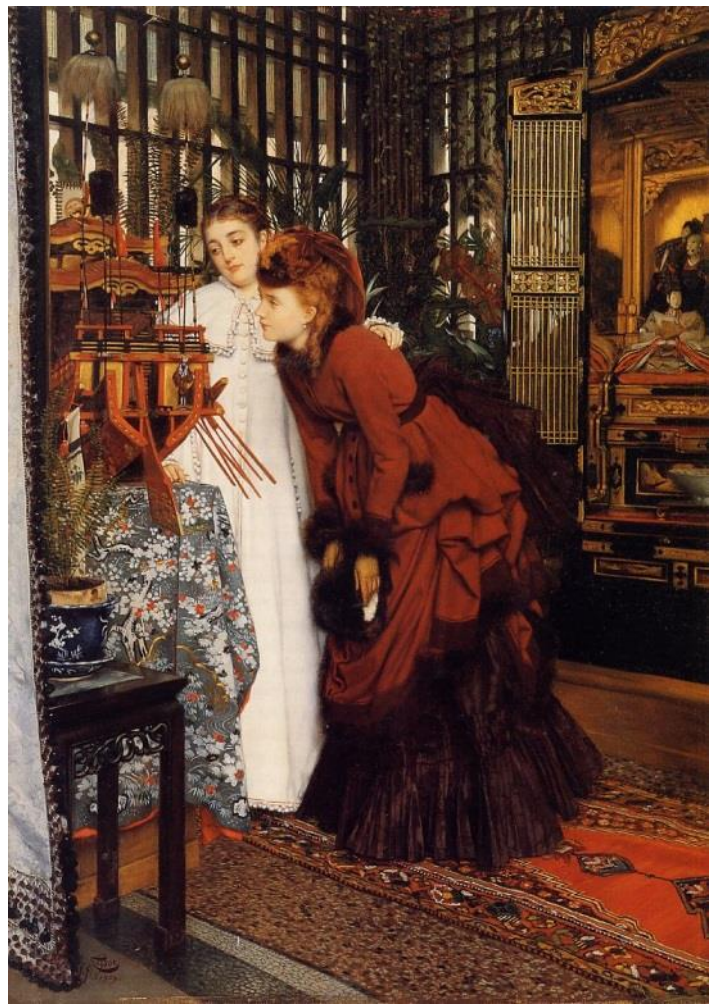

Fonte: http://www.jamestissot.org 
Um dos pintores que correm o risco de cair em equívocos ao ser classificado é James Abbott McNeil Whistler, citado em páginas anteriores. Por ser um dos primeiros colecionadores de artigos nipônicos, torna-se o pioneiro a incorporar e a difundir elementos japoneses com função decorativa em suas obras, algumas datadas no começo de 1860 . Sua admiração pode ser conferida nas obras denominadas $O$ biombo dourado (Figura 19), A Princesa da Terra das Porcelanas, Sinfonia em branco, Roxo e Rosa, entre outras. Por suas pinturas estabelecerem mais componentes ocidentais com apenas detalhes japoneses, ele é comumente analisado apenas em seu período prematuro, dito superficial. Contudo, na década de 1870, suas obras passaram a exibir um maior interesse na estética japonesa e em suas complexidades, evidenciando conhecimento dos princípios compositivos japoneses. $\mathrm{Na}$ obra A Sacada, que pode representar um momento de transição, apesar do elemento óbvio, o quimono, a composição é arranjada de forma muito similar à xilogravura de Hokusai. As poses, a sacada, a linha do horizonte, inclusive a presença de uma montanha ao fundo, são indícios claros da influência (Figura 20). Outra obra que denuncia o Japonismo nas obras de Whistler, porém de modo ainda menos evidente, e até mesmo despercebida aos olhos amadores, é a Noturno em Azul e Ouro: A velha ponte de Battersea (Figura 21), de, aproximadamente, 1872-75. Nessa pintura, há aspectos de composição diferenciados, similares às composições feitas por Hiroshige (BREUER, 1994).

Figura 19-O Biombo Dourado. James Whistler, 1864

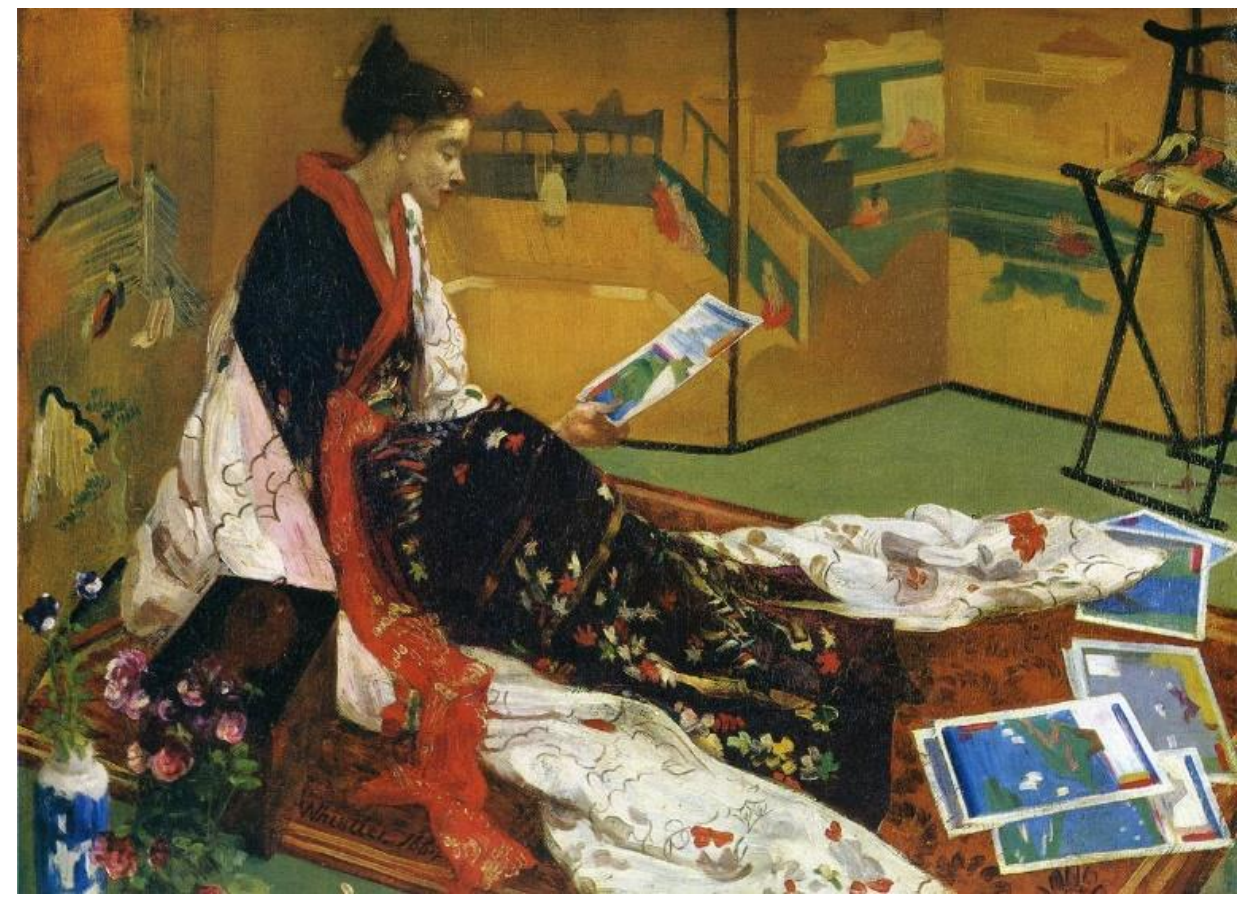

Fonte: http://www.jamesabbottmcneillwhistler.org 
Figura 20 - Imagens comparativas: Detalhe da xilogravura da série 36 visões do Monte Fuji, Katsushika Hokusai e A Sacada, James Whistler, 1870

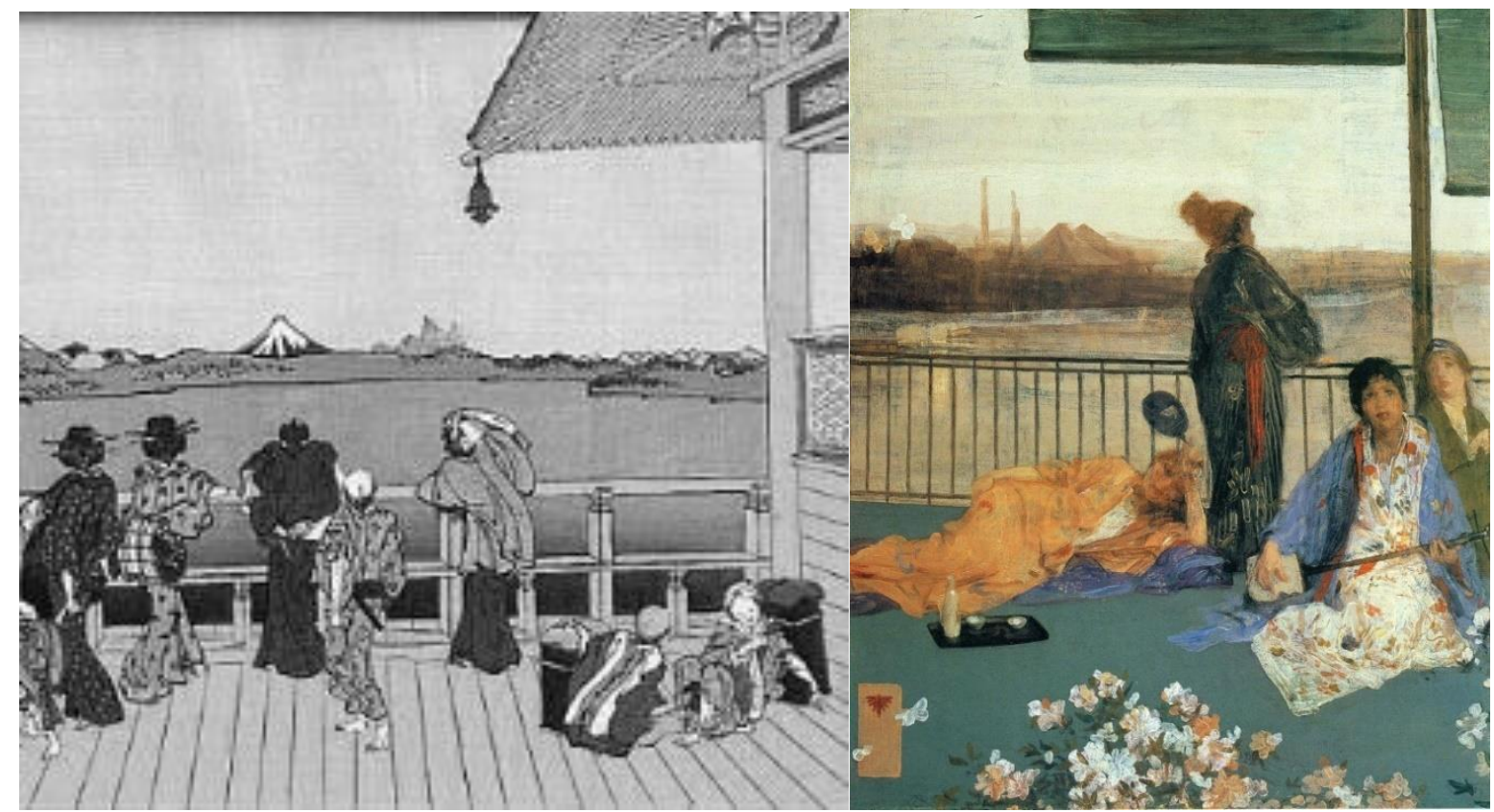

Fonte: http://ukiyo-e.org

Fonte: http://www.jamesabbottmcneillwhistler.org

Figura 21 - Noturno em Azul e Ouro: A velha ponte de Battersea. James Whistler, entre 1872 e 1875

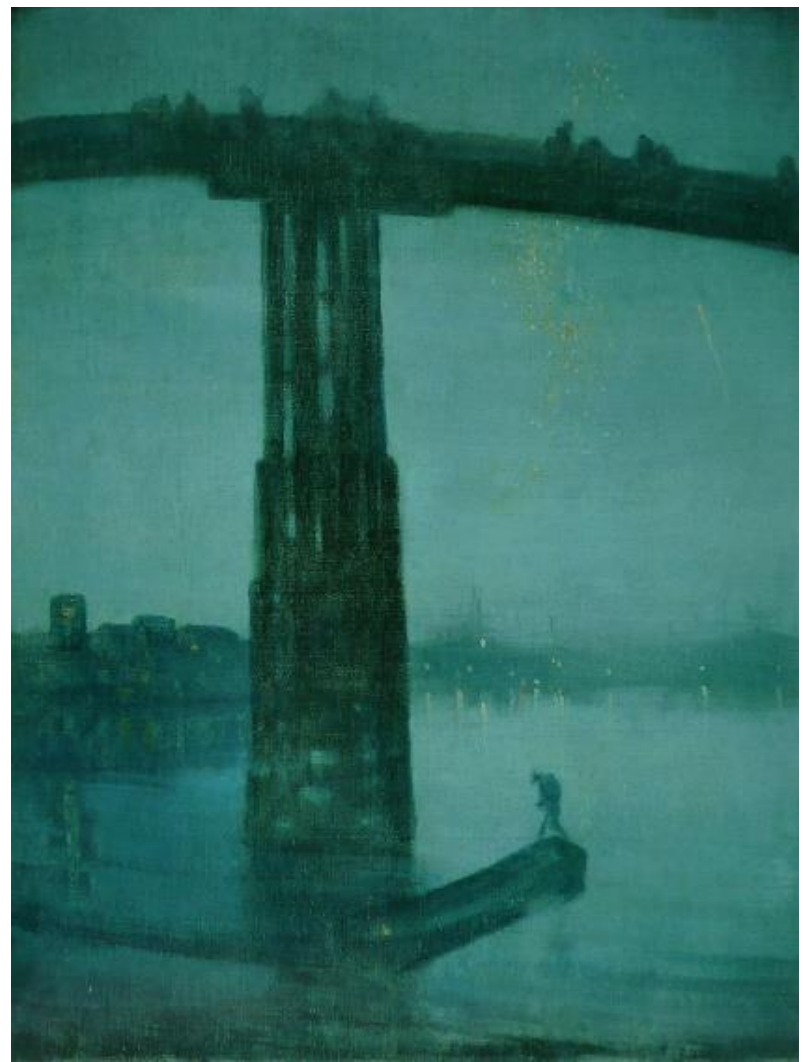

Fonte: http://www.tate.org.uk/art/artworks 
Figura 22 - Ponte Kyōbashi. Utagawa Hiroshige, c. 1857

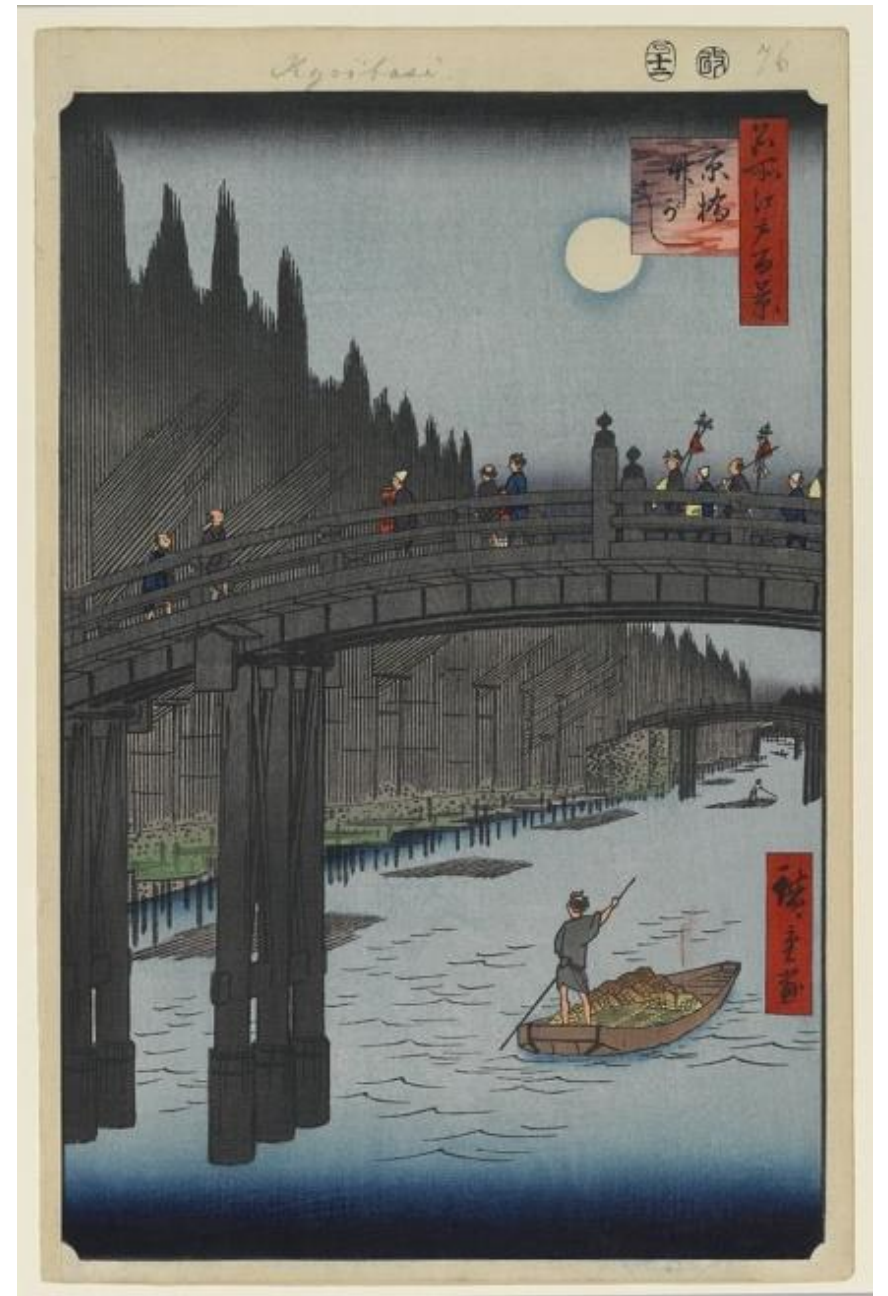

Fonte: http://www.brooklynmuseum.org

Em 1876, Claude Monet finaliza a obra na qual retrata sua esposa Camille em um robe teatral decorado. Apesar de, atualmente, ser conhecida como La Japonaise (literalmente "A Japonesa") (Figura 23), sua denominação original de 1876 era Japonerie, sinônimo e anterior ao Japonismo (MENG; ATSUKO, 2013). Esse fato evidencia que, ao contrário do que muitos estudiosos afirmam, a inclusão de elementos japoneses não era necessariamente um exercício de mera imitação, mas, como sugere a nominação original de Monet, expressa a confluência entre as duas culturas. Nesse sentido, essa pintura, ao mesmo tempo que possui vários indicativos orientais, a presença de outros elementos confirma sua identidade ocidental, como a peruca loira e o leque com as cores da bandeira francesa. 
Figura 23 - La Japonaise. Claude Monet, 1876

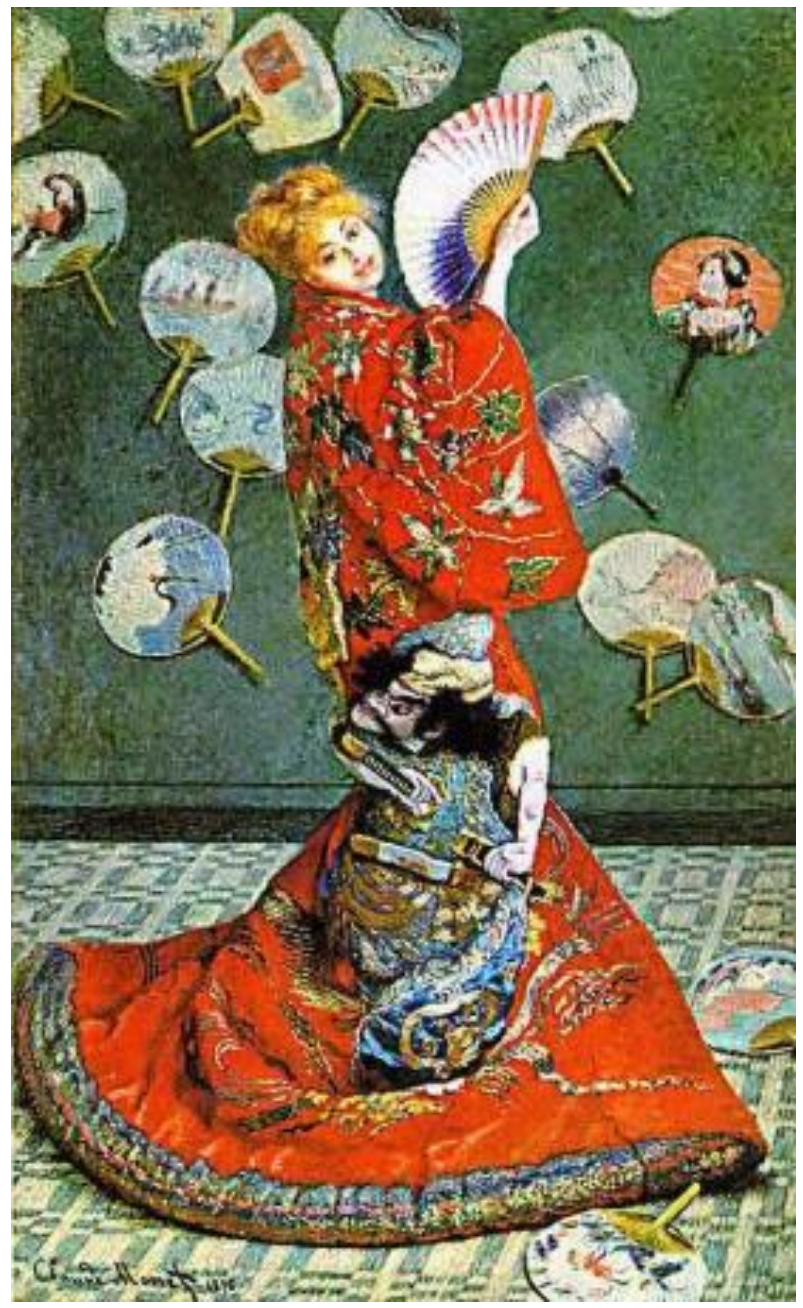

Fonte: http://www.mfa.org/collections

Entre as relevantes obras do Japonismo encontra-se também o nome de Édouard Manet, já mencionado, regularmente considerado "pai do Impressionismo". Wichmann (2007) garante que esse artista foi um dos primeiros pintores que não apenas absorveu os temas, como ainda incorporou aspectos da arte do Japão. Mesmo que não tão aparentes como seus contemporâneos, é evidente no Retrato de Emile Zola (Figura 24), de 1868, a exploração dos aspectos ocidentais e orientais em uma síntese bem-sucedida.

Kuvatova (2012), ao se referir a ele, comenta que ele insere características da arte clássica - como a inclusão de objetos relacionados à pessoa retratada - mas permanece um pintor contemporâneo, cuja atitude em relação à modernidade está conscientemente traduzida pelos detalhes: a gravura ukiyo-e, o biombo japonês, a fotografia de sua obra Olympia. 
Figura 24 - Retrato de Émile Zola. Édouard Manet, 1868

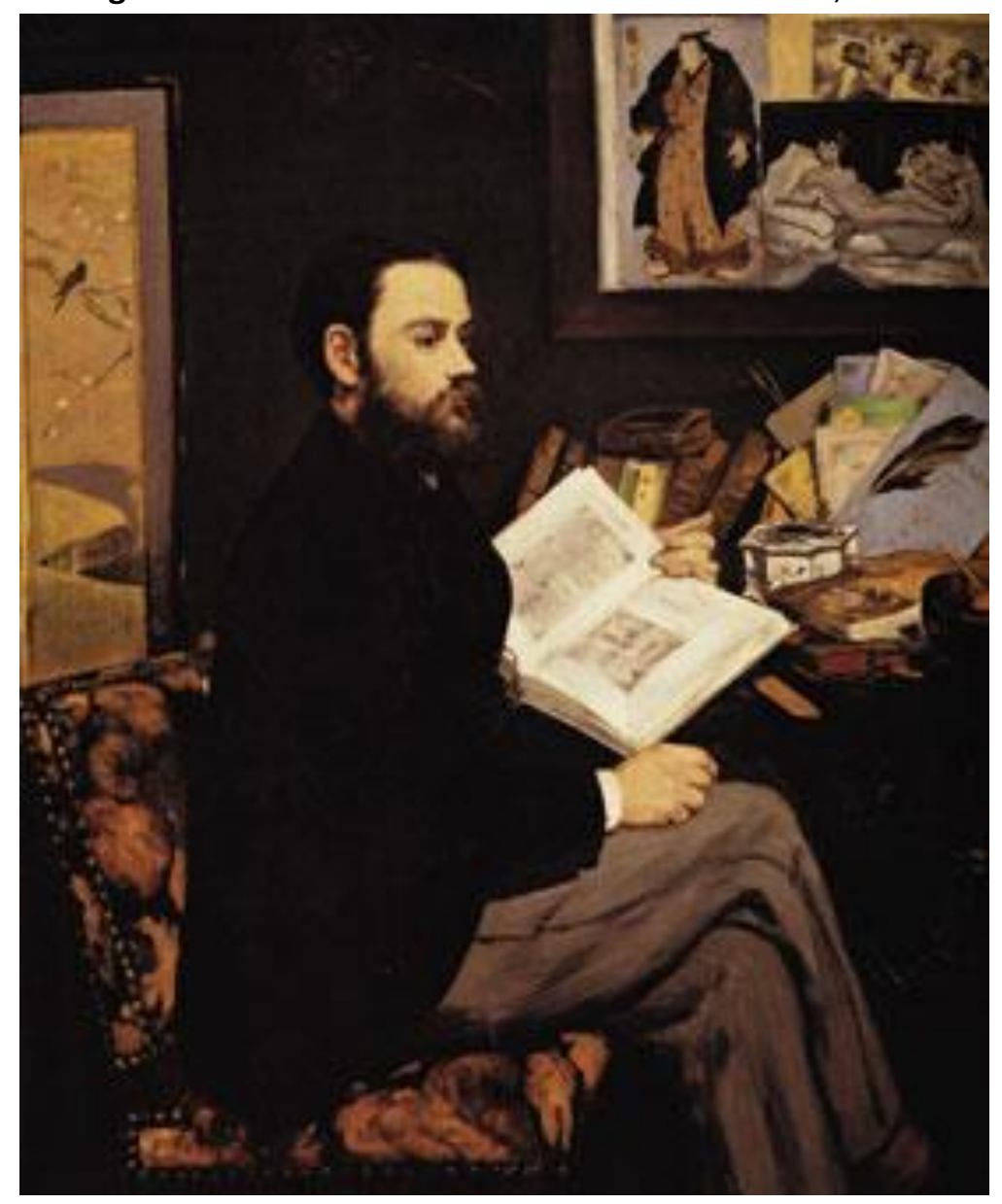

Fonte: http://www.musee-orsay.fr/en/collections

A célebre série de Hokusai, já mencionada, Trinta e seis visões do Monte Fuji, resultou na correspondente homenagem Trinta e seis visões da Torre Eiffel (Figura 26), no qual o artista francês Henri Rivière (1864-1951) revela a torre sob vários pontos de vista e em diferentes momentos e condições climáticas, tal qual como nas observações das viagens de Hokusai (Figura 25).

Além desses aspectos, é possível perceber no canto inferior direito da Figura 26 mais uma clara referência à arte japonesa: a adição do "selo" de autoria do projeto, construído de forma que suas iniciais remetessem ao ideograma.

De acordo com Schapiro (2002, p. 32)

[...] os pontos de vista dos pintores-observadores, eram, com frequência, semelhantes à dos andarilhos ou viajantes, cuja relação com o ambiente não era a mesma dos habitantes de pequenas cidades ou fazendeiros, mas a dos espectadores de férias que se deleitavam com o revigoramento dos sentidos propiciado pela paisagem, às sensações expansivas de liberdade e harmonia. 
Figura 25 - Fuguku hyakkei da série Cem Visões do Monte Fuji. Katsushika Hokusai

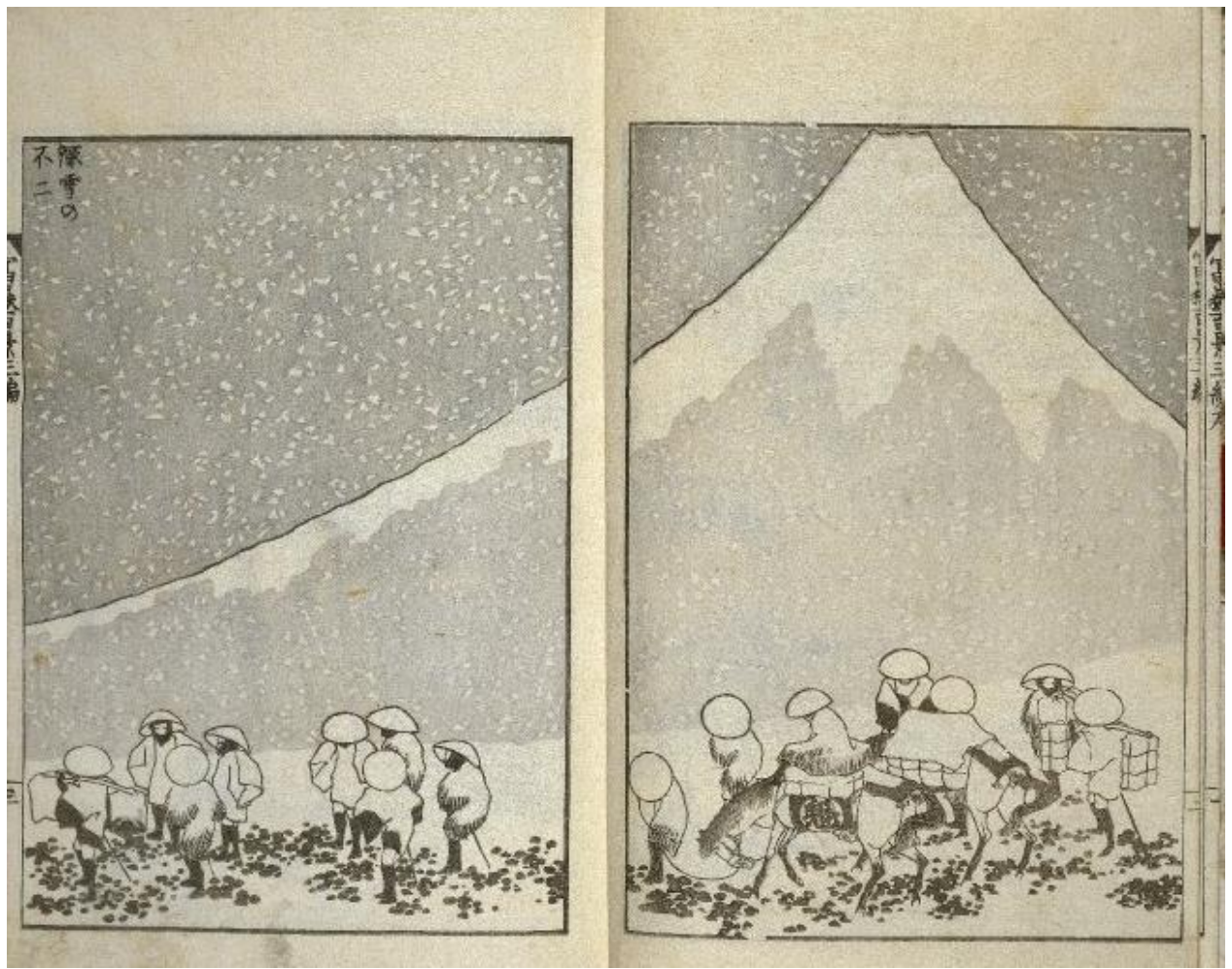

Fonte: http://www.britishmuseum.org/research/collection_online

Figura 26 - A Torre em Construção, como visto do Trocadéro da série Trinta e seis visões da Torre Eiffel. Henri Rivière, 1902

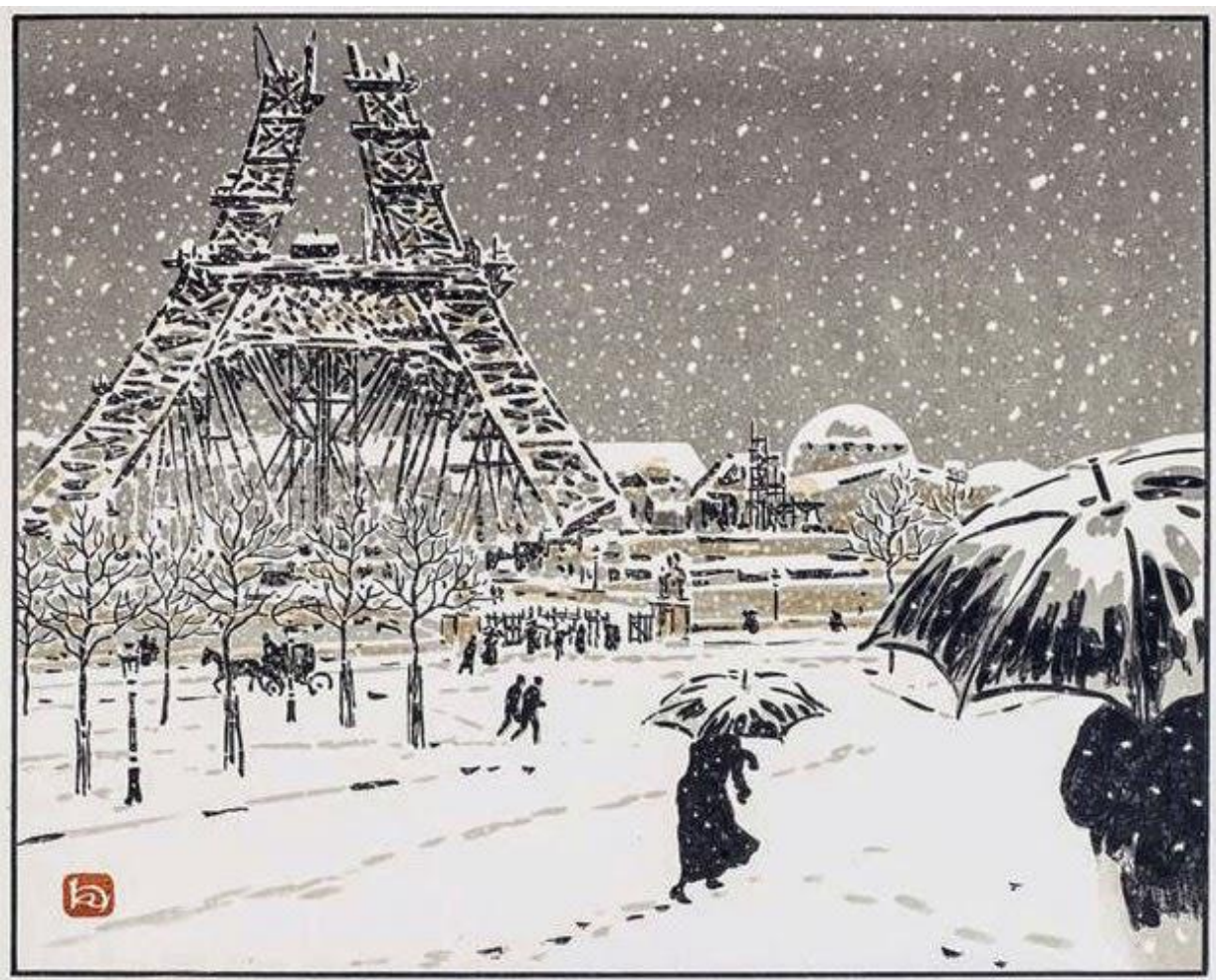

Fonte: https://art.famsf.org/henri-rivière 
Monet também produziu, na década de 1890, uma série com perspectivas semelhantes. Ele cria cerca de trinta quadros paisagísticos de um único tema, a Catedral de Rouen, no qual a reproduz em diversos momentos do dia (WILDENSTEIN, 1999).

No mesmo período, outros pintores, também mergulhados na onda japonesa, sequer se prenderam à abordagem de representação de objetos oriundos no Japão, como leques, quimonos, e outros bibelôs; todavia, foram capazes de digerir e apreciar a estética japonesa em perspectivas mais profundas e por isso, aplicaram-na de forma menos evidente.

O pintor Vincent van Gogh, a quem foi posteriormente atribuído o titulo de pósimpressionista, desenvolve uma intensa e apaixonada relação com o Japão que se inicia a princípio na Antuérpia (Bélgica) e se intensifica quando chega a Paris. Sua residência, que se fixava próximo à loja do já citado Siegfried Bing, levou-o a compor não só uma vasta coleção de mais de quatrocentas gravuras japonesas, mas também propiciou um grande interesse pela cultura japonesa em geral (WICHMANN, 2007).

Por causa disso, ele foi um pintor que não só se estabeleceu como representativo como também explorou consideravelmente os aspectos estéticos japoneses. Entre várias obras com referências japonesas, estão dois retratos similares de Père Tanguy (Figura 27) um fornecedor de materiais artísticos - que possuem um fundo complexo composto por inúmeras gravuras. Ambos os retratos se caracterizam pela imagem e composição plana, que denunciam a total despreocupação em criar uma ilusão de realismo.

De acordo com Wichmann (2007, p. 40) para ele, "a influência da arte japonesa marcou como a mudança que iria varrer os velhos conceitos acadêmicos, clássicos da arte europeia. Em suas cartas, a inesgotável imaginação e o zelo missionário se combinam para emitir uma enxurrada de ideias criativas". 
Figura 27 - Retrato de Père Tanguy (com ukiyo-e ao fundo). Vincent van Gogh, 1887

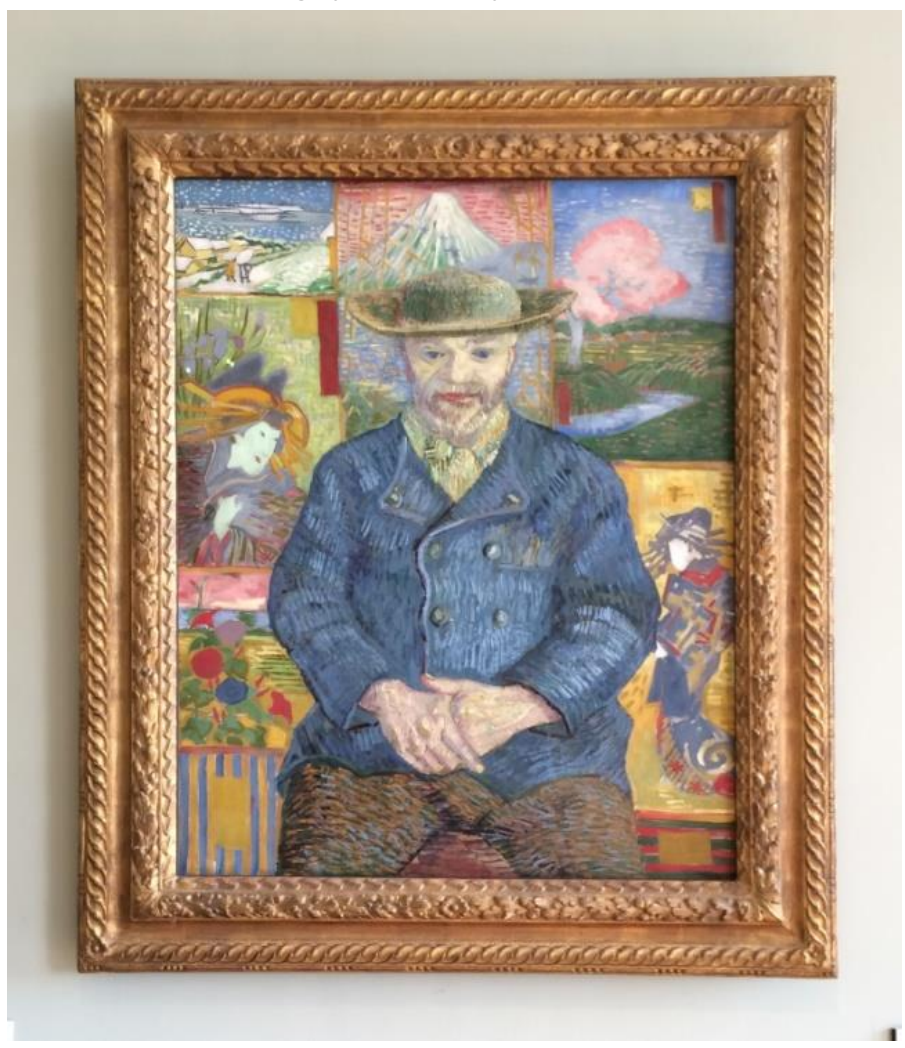

Fonte: Acervo de Luciana Iwamoto

Essa influência começou a ser concretizada em Paris na forma de uma cópia cuidadosa de Hiroshige, da série Cem visões de Edo (Figura 28). Anos depois, Lambourne (2005, p. 4) registra que o arquiteto americano e comerciante de gravuras japonesa Frank Lloyd Wright (1867-1954), comenta sobre a obra de van Gogh nos seguintes termos: "Há um que Van Gogh copia "Após Hiroshige" ele chamou - mas eu não consegui ver nada além uma pintura a óleo da impressão. Eu não acho que ele fez um bom trabalho, a impressão era tão superior que era até desagradável olhar para o que ele fez". 
Figura 28 - Imagens comparativas: Chuva repentina sobre a ponte Shin-Ōhashi e Atake, Utagawa Hiroshige, 1855 e Ponte sob a chuva - após Hiroshige, Vincent van Gogh, 1887

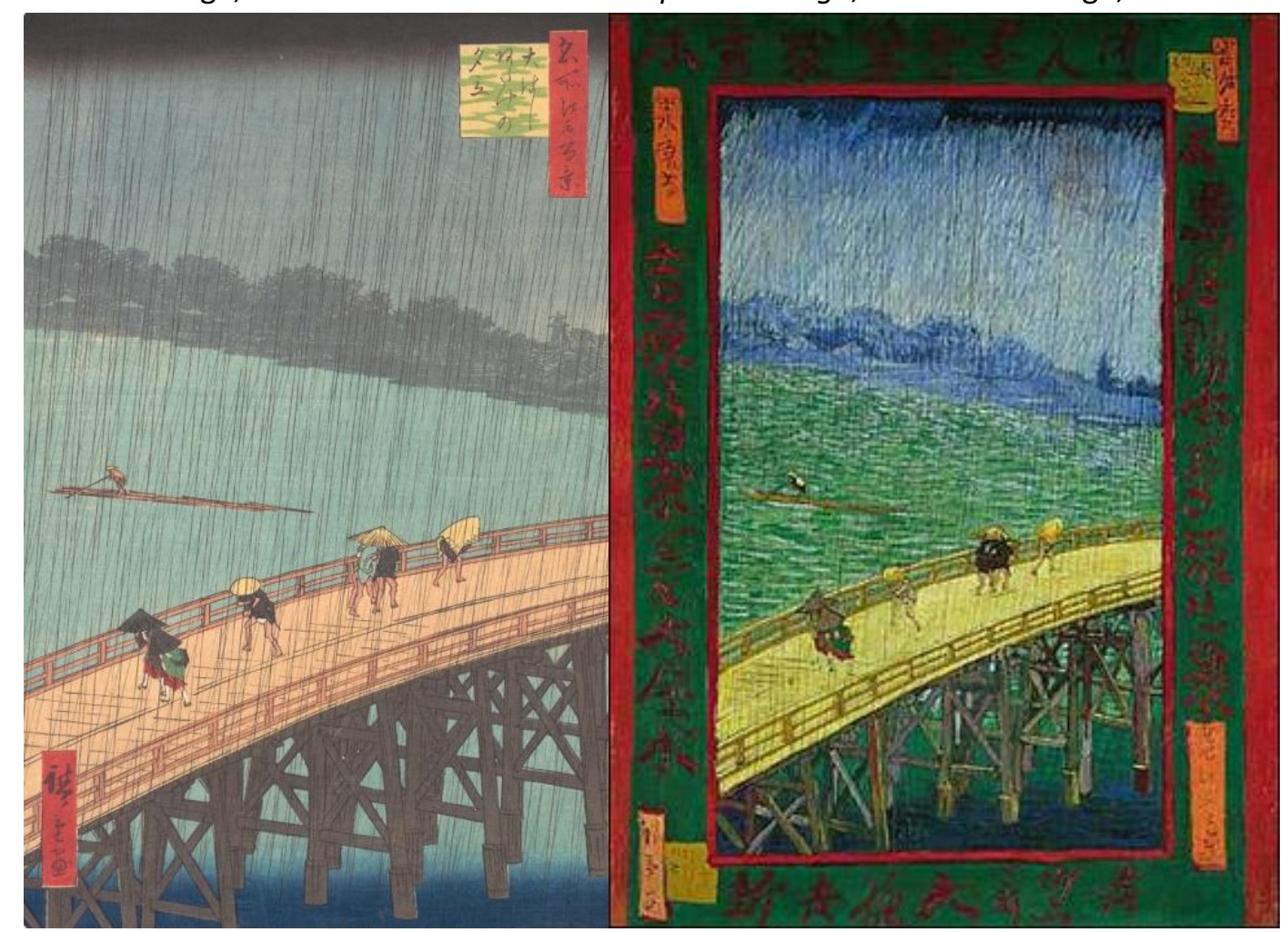

Fonte: http://www.brooklynmuseum.org

Fonte: www.vangoghmuseum.nl

O objetivo de van Gogh, diferentemente do que atestou Wright, não era simplesmente a cópia das gravuras, mas configurava-se como parte de um processo de estudo de estilo, cor e composição. Ele, que deliberadamente escolheu gravuras de Hokusai a fim de absorver toda a beleza das cores, retrata-o ainda com mais contraste e vivacidade.

Ele não queria compreender a arte japonesa pela simples reprodução, mas sim mergulhar a fundo nas raízes da própria cultura japonesa, a fim de ser capaz de gerar impulsos criativos originais de sua autoria. Daí porque Lambourne (2005) assegura que o Japão era, para ele, um sonho utópico. Nunca teria colocado os pés no Japão, mas sua grande admiração o levou a adquirir uma visão pessoal, como ele mesmo disse, "com um olhar mais japonês".

Em Arles, sul da França, cidade em que viveu por catorze meses, van Gogh identificou a simplicidade e a beleza japonesas, apresentadas a ele pelas suas gravuras tão admiradas. "Por mim eu não preciso de imagens japonesas aqui, pois eu sempre digo a mim mesmo que estou no Japão. O que significa que eu só tenho que abrir meus olhos e pintar o efeito do que está bem na minha frente" (DOUMA, 2015). Nesse período, sua produção foi expressiva, com cerca de duzentas obras-primas. 
Para Wichmann (2007), uma das demonstrações de sua inegável admiração pela cultura japonesa é o seu autorretrato de 1888, ocasião essa em que corta o cabelo tal como um monge budista, religião que, ao mesmo tempo, o empolgava e perturbava-o. Daí que Douma (2015, n.p.) relata que ele escreve para seu irmão Theo: "produzi um novo autorretrato, um estudo, no qual eu pareço um japonês".

Figura 29 - Autorretrato dedicado a Paul Gauguin. Vincent van Gogh, 1888

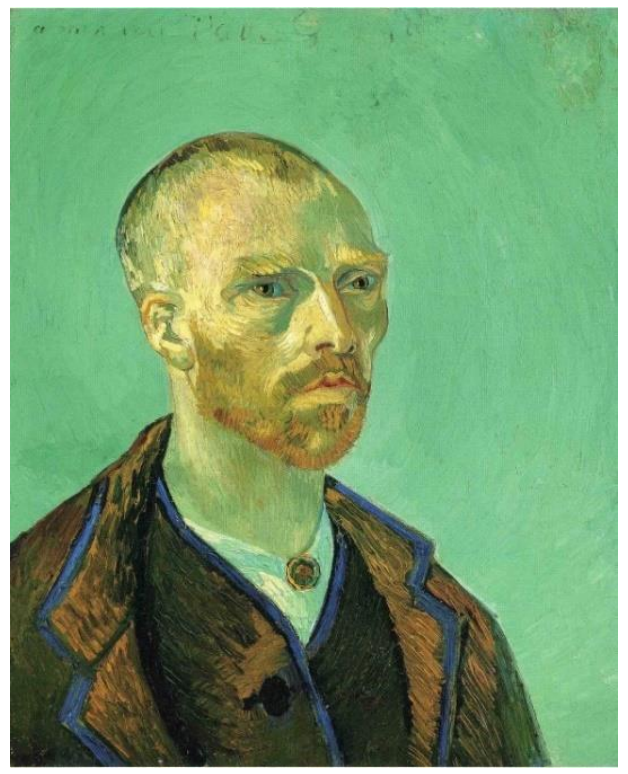

Fonte: http://www.jamestissot.org

Essa obra também se articula com a obra literária do novelista Pierri Loti (1850-1923), legado da influência nipônica, Madame Chrysanthème, lançada no ano anterior, ou seja, em 1887, história na qual teve como protagonista uma gueixa e que Van Gogh possuía ciência, confirmado através de suas inúmeras cartas.

Ele, porém, não foi o único de sua época a possuir tais imagens orientais tão impregnadas a ponto de fazê-lo construir a figura de um Japão ideal e a identificá-lo em outros locais. Claude Monet, em 1895, declara em sua viagem para a Noruega (LAMBOURNE, 2005, p. 48): “Tenho aqui um delicioso motivo, pequenas ilhas ao nível da água cobertas pela neve, e uma montanha ao fundo, na qual é vista de todos os lugares e que me faz pensar em fujisan".

Monet, que anteriormente retratou sua esposa em um vibrante robe vermelho, passa a absorver a influência das gravuras japonesas de forma mais conceitual e na concepção 
criativa. Sua coleção de gravuras estava acessível nas paredes sua casa, em Giverny (Figura 30 e Figura 31), assim como muitos elementos japoneses foram incorporados, de modo inconsciente por ele em seu jardim, o qual foi muito utilizado como temática em suas obras. Lambourne (2005) destaca a ponte em meia-lua, as peônias japonesas e as cerejeiras (Figura 32).

Figura 30 - Claude Monet em Giverny em sua sala de jantar decorada com gravuras ukiyo-e

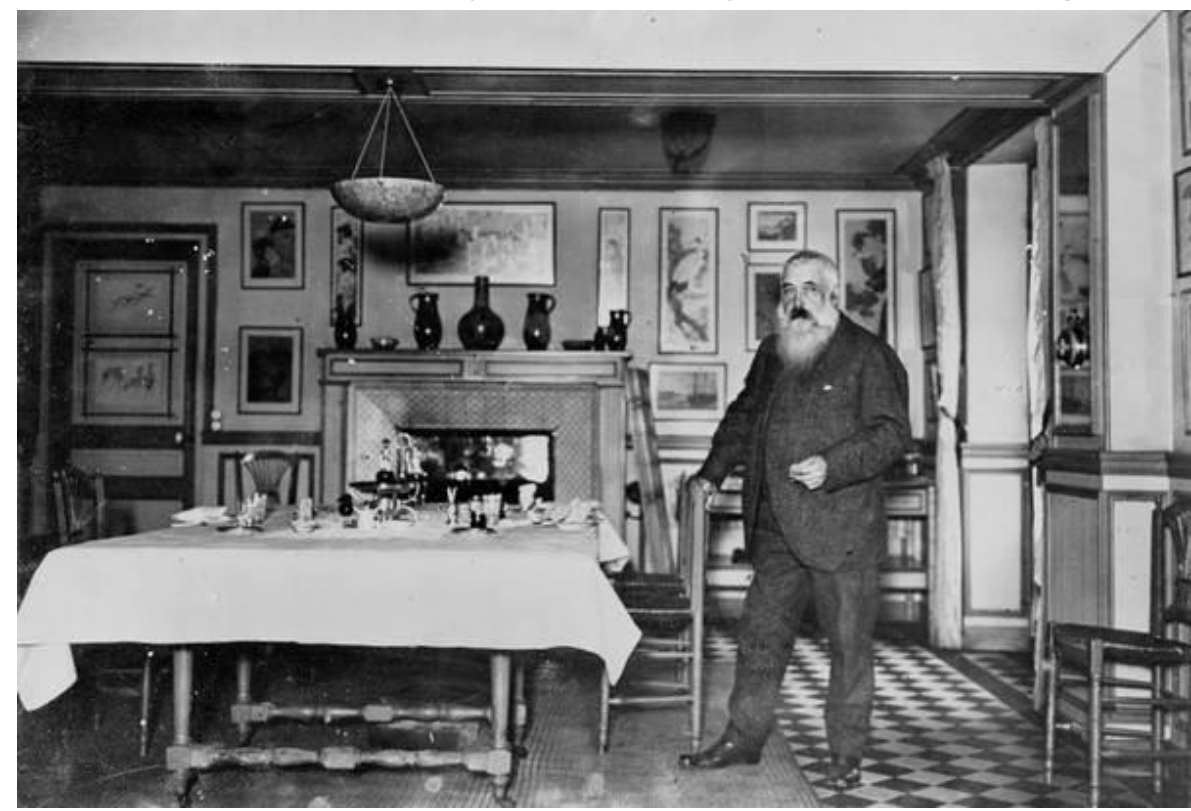

Fonte: http://www.intermonet.com/japan

Figura 31 - Detalhe da casa de Claude Monet em Giverny, decorada com estampas ukiyo-e

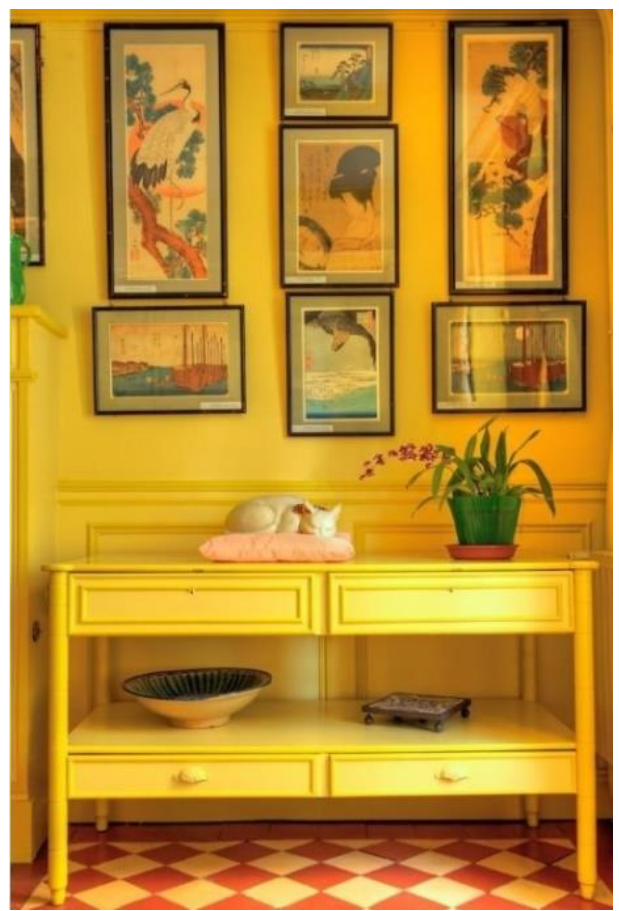

Fonte: http://giverny.org/monet/home 
Figura 32 - Comparação: Xilogravura de Utagawa Hiroshige, 1856 e Ponte Japonesa em Giverny, Claude Monet, 1889

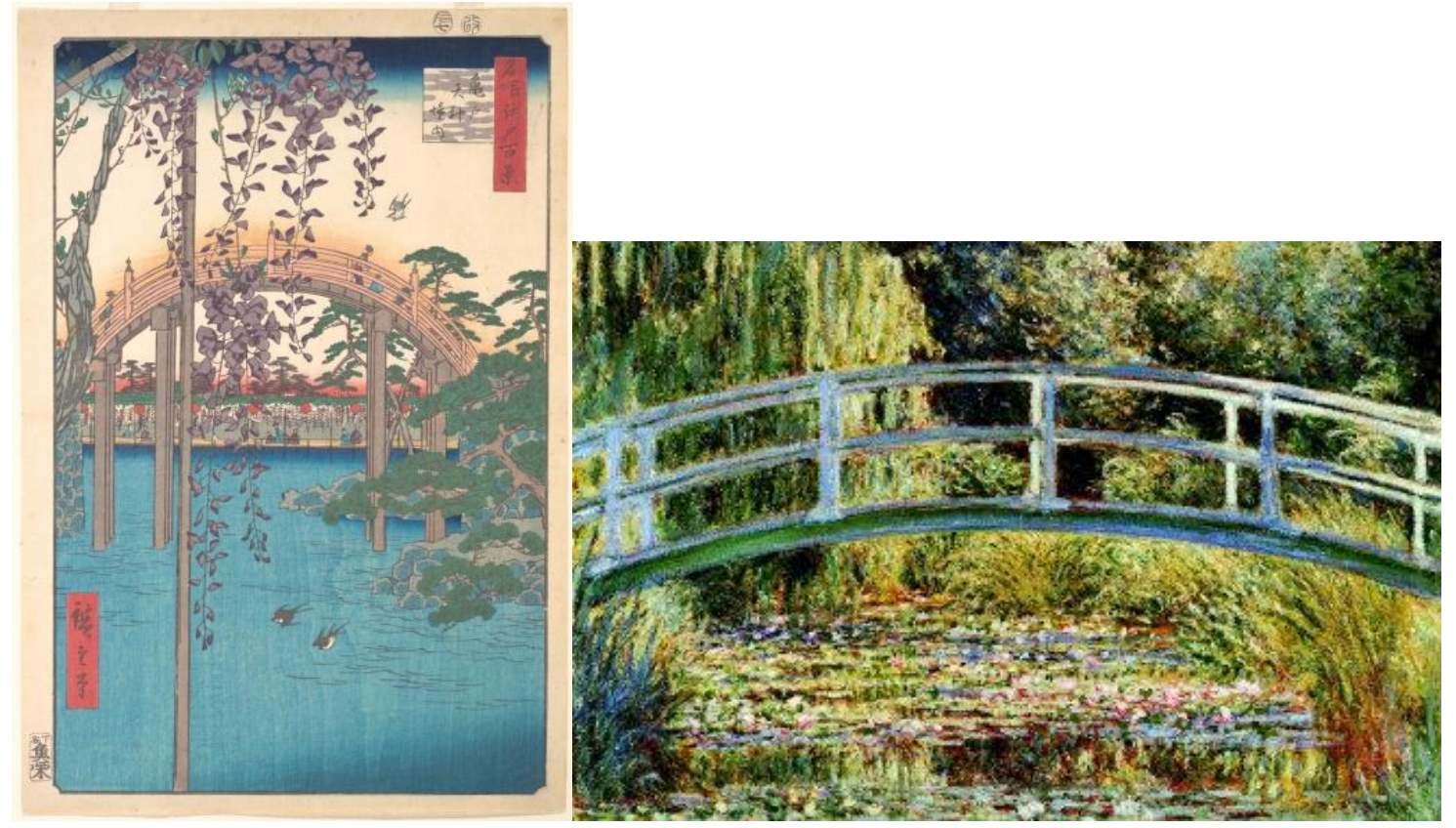

Fonte: http://ukiyo-e.org/image

Fonte: http://www.claudemonetgallery.org

Tinterow e Loyrette (1994) frisam que era claro o entendimento de Monet das possibilidades revigorativas que a arte japonesa podia oferecer era clara, de modo que se volta a ela ao longo de sua carreira, não somente no fim do século XIX, quando busca aumenta seu repertório de motivos, mas também no início do século $X X$, em seus famosos lírios. Esses mesmo autores descrevem que o horizonte alto, as composições assimétricas e as cores brilhantes, especialmente a turquesa incomum da água, traem o intenso interesse de Monet pelo Japão. Nesse momento, o Impressionismo já era reconhecido e já havia se tornado parte da vida cultural francesa e, ironicamente, da academia, marcando, enfim, o triunfo desse movimento.

Além da representação particular do cotidiano, da natureza e do entretenimento, os pintores também se inspiram nas temáticas íntimas do cotidiano observadas com muita frequência nas xilogravuras japonesas, legado principalmente de Utamaro.

Edgar Degas, dito como provavelmente o pintor mais influenciado pela arte japonesa, enfatizou essa concepção ao compartilhar com os mestres japoneses o intenso interesse pela temática feminina. Suas mulheres, longe de serem idealizadas, são retratadas engajando-se em seus afazeres banais, porém, transplantadas para sua realidade parisiense. Sua influência, 
apesar de notória, é tratada de forma subjetiva, menos clara à primeira vista (WICHMANN, 2007).

Segundo Gombrich (1993), o nu, que existia em abundância na arte europeia antes do encontro com a arte japonesa, era aceitável desde que representasse um tema clássico; todavia, se ele fosse posicionado em um contexto contemporâneo desprovido de clássicos adornos, sua moralidade seria contestada. Degas começa a tratar o nu da mesma forma como os mestres japoneses - que não era necessariamente associado ao erótico - ao mesmo tempo em que rejeita categoricamente a prática habitual de deusas, odaliscas ou outras figuras lendárias como pretextos para representações artísticas. Tinterow e Loyrette (1994), atestam que Degas teria declarado que, em séculos anteriores, ele teria pintado Susana no banho, ao invés de mulheres em banheiras (Figura 33).

Piotr (2013), em seus estudos sobre a delicadeza da arte ilustrada no Japão, defende que a arte do ukiyo-e foi um catalisador importante neste processo de "emancipação do nu". Aliados a essa inovação, os rascunhos, principalmente de Hokusai, renderam aos artistas europeus poses, gestos e posições até então inconcebíveis (Figura 38, Figura 39 e Figura 41).

Figura 33 - A Banheira. Edgar Degas, 1886

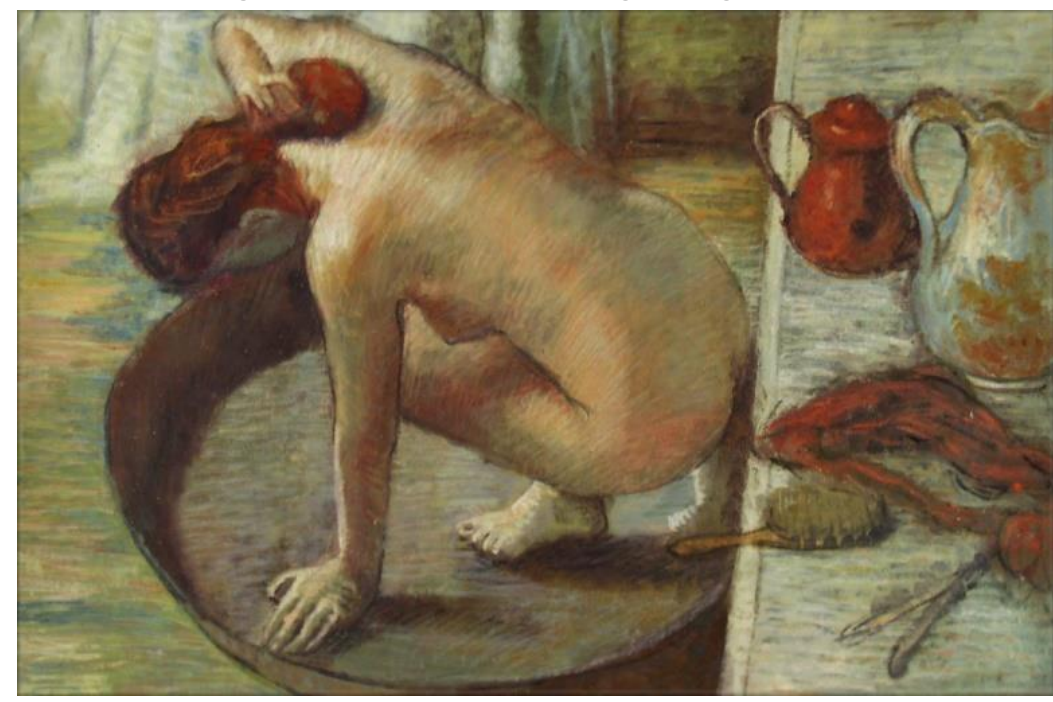

Fonte: http://www.musee-orsay.fr 
Figura 34 - Casa de Banho. Torii Kiyonaga

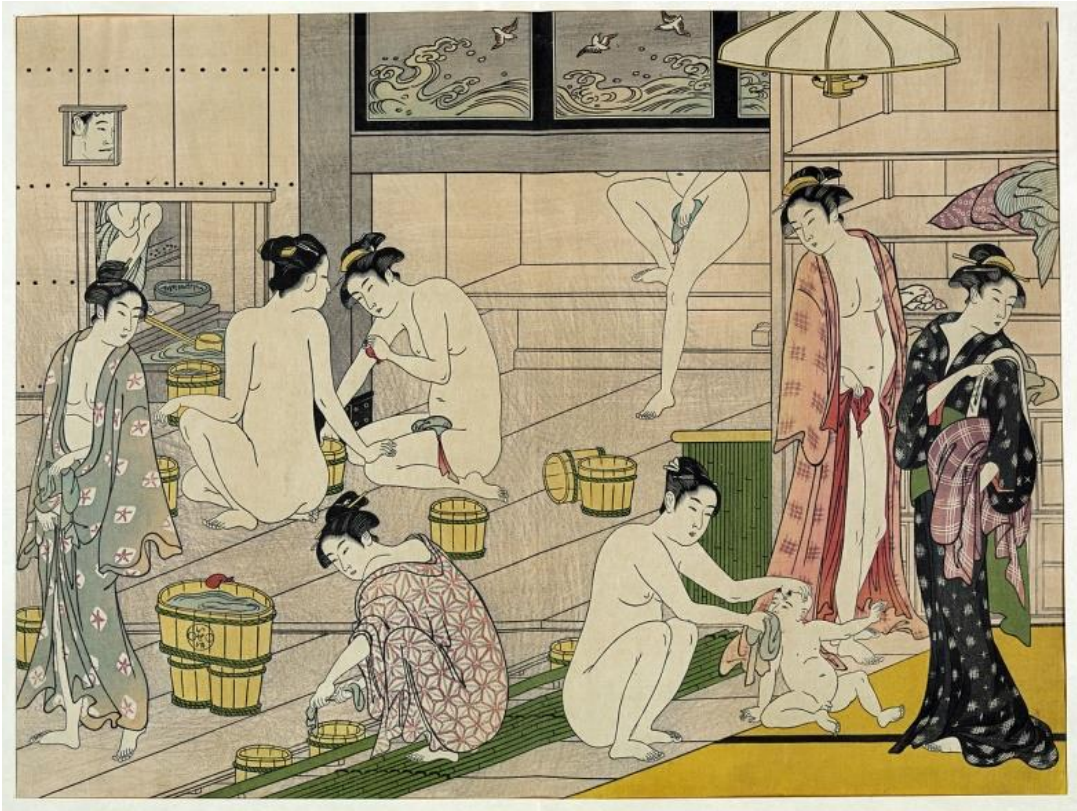

Fonte: http://en.wikipedia.org/wiki/Torii_Kiyonaga

As figuras comparativas abaixo (35 e 36) mostram a influência na temática de Degas, as quais longe de serem retratadas como ideais, ocupam-se com tarefas diárias.

Figura 35 - Xilogravura Mulher Penteando os Cabelos da série Dez Estudos Fisionômico da Mulher. Kitagawa Utamaro, c. 1802

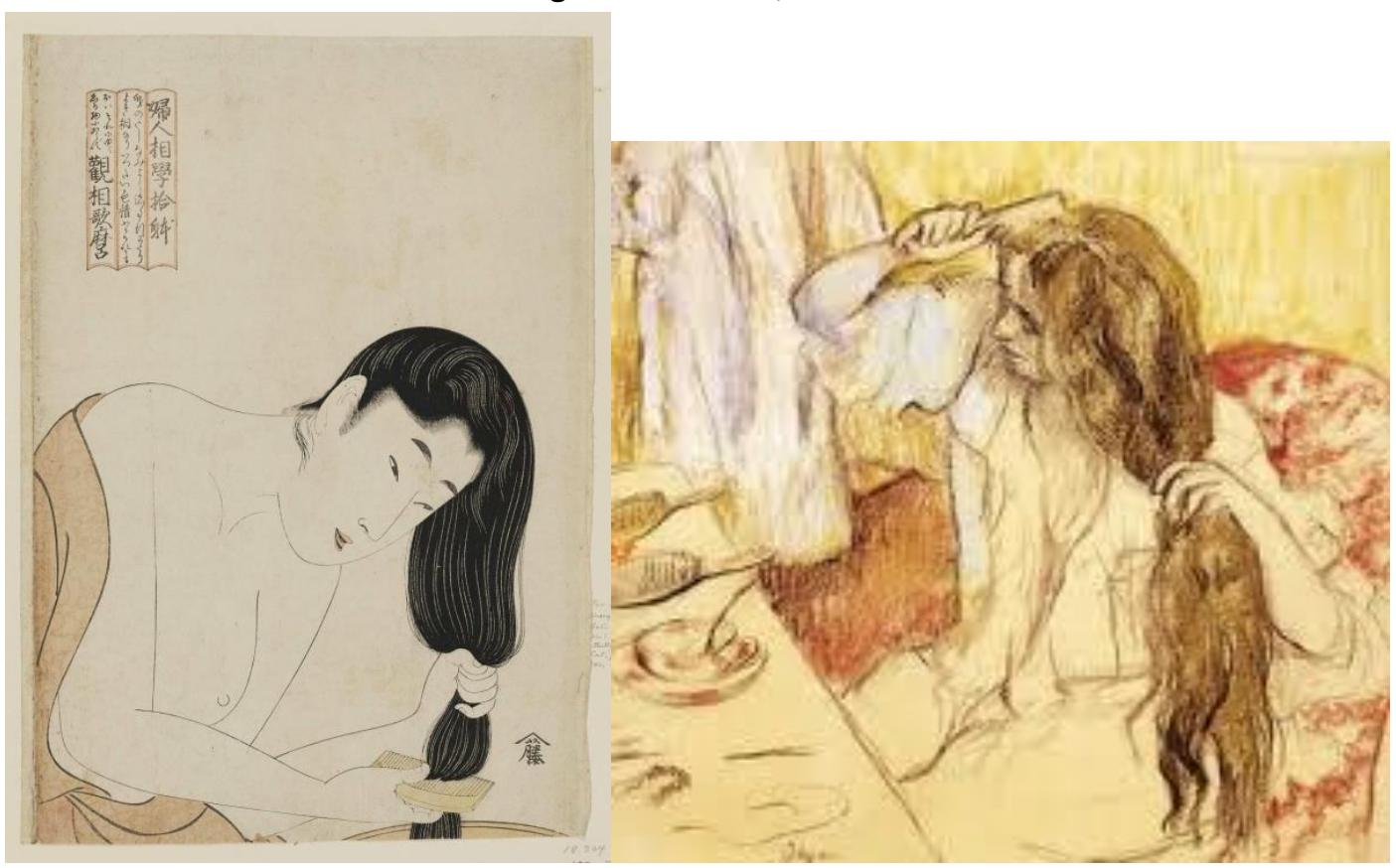

Fonte: http://ukiyo-e.org/image

Fonte: http://www.metmuseum.org 
Figura 36 - Comparação: xilogravura de Kitagawa Utamaro, período Edo e Mulher tendo seu cabelo escovado, Edgar Degas, 1895

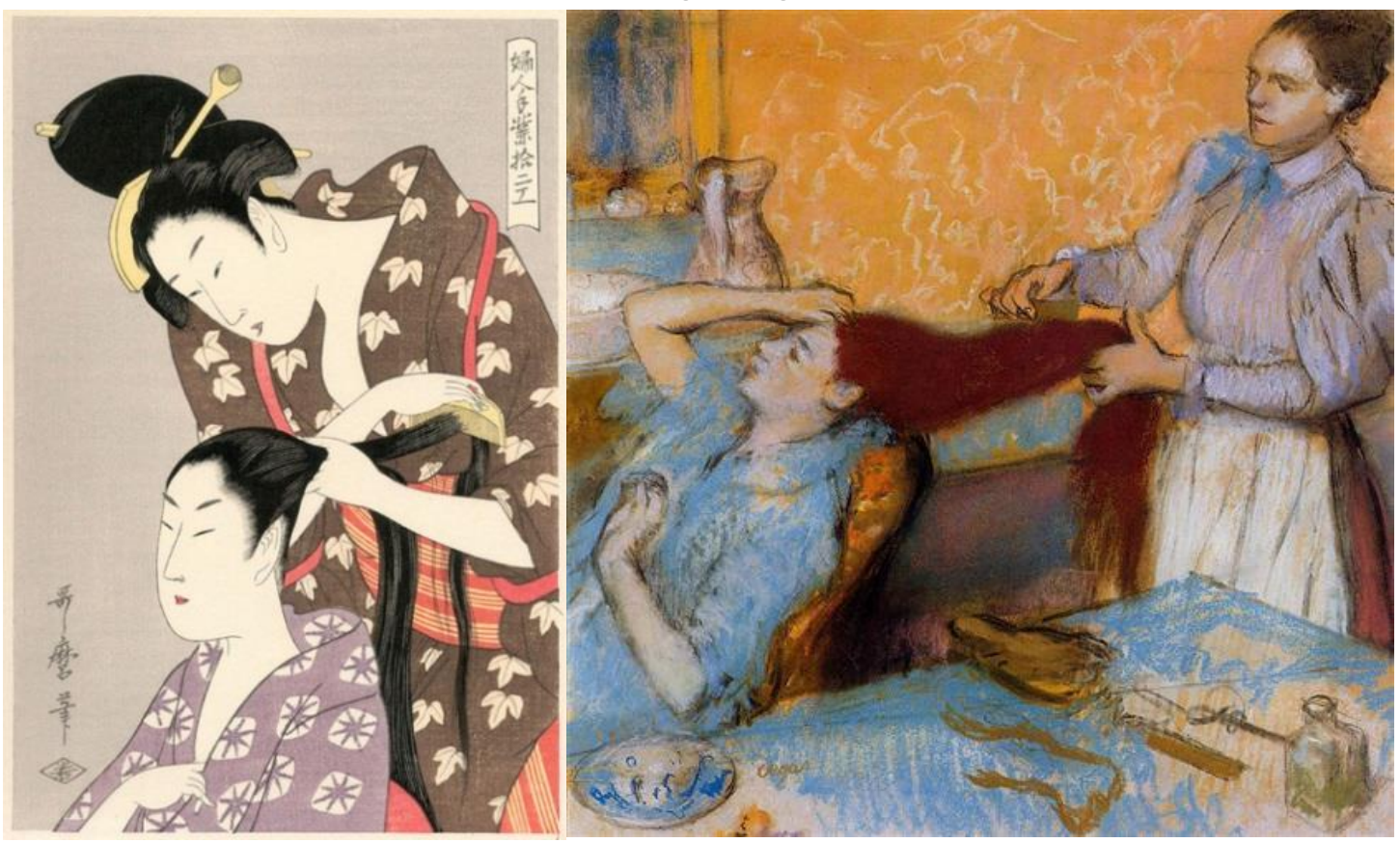

Fonte: http://ukiyo-e.org/image

Fonte: http://www.wikiart.org/en/edgar-degas/woman-having-her-hair-combed

A já citada pintora Mary Cassat, uma grande admiradora de Degas, também se empenha em estudar as tão famosas gravuras japonesas. Ela que, deliberadamente, afirmava que odiava a arte tradicional, empresta muitas das temáticas intimistas observadas na arte nipônica, com ênfase nos estreitos laços envolvendo mãe e filho e nas ações solitárias (Figura 37 e Figura 38) (WEINBERG, 2014). 
Figura 37 - Comparação: Xilogravura de Kitagawa Utamaro, 1803 e O banho da criança. Mary Cassatt, 1893

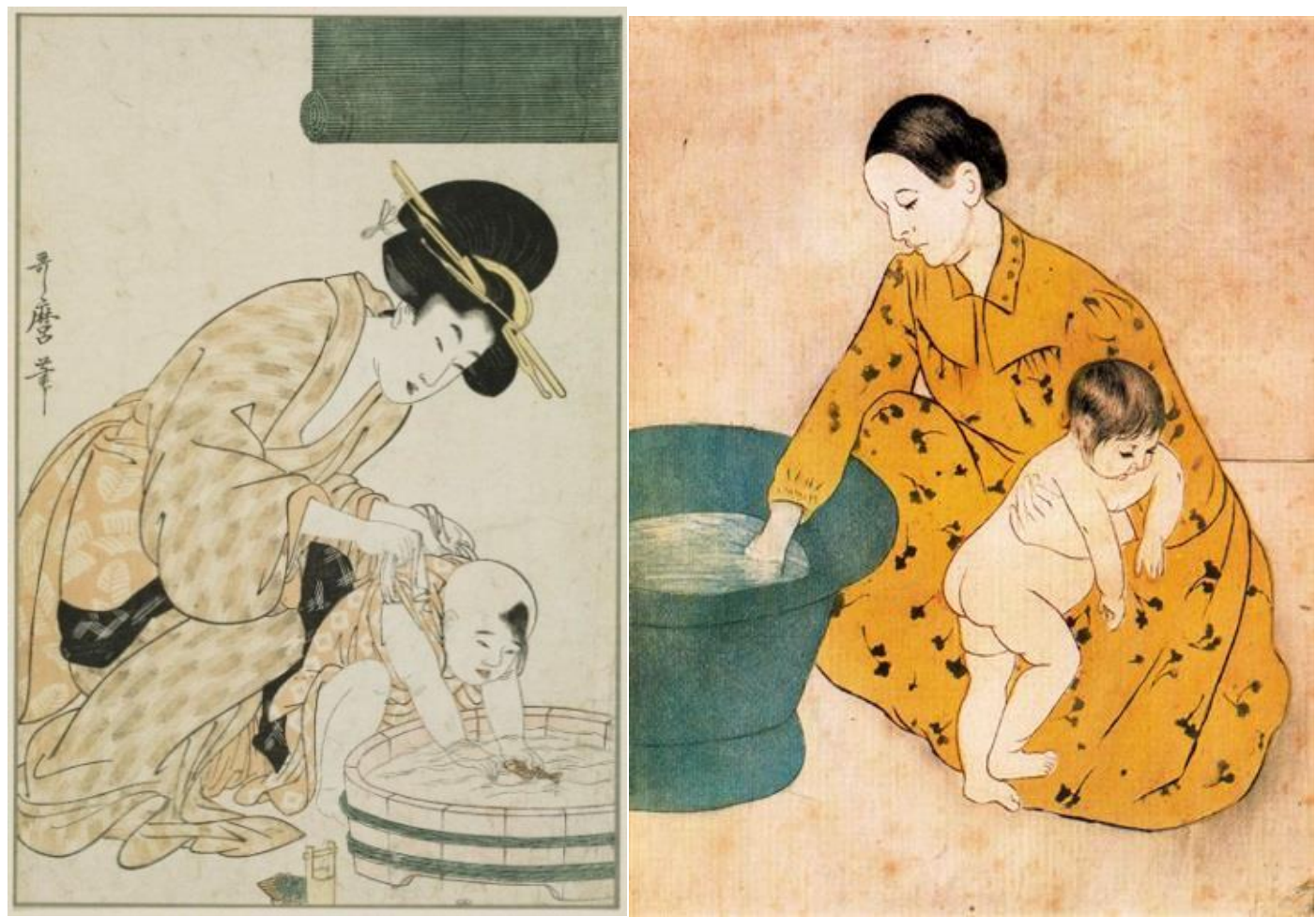

Fonte: http://ukiyo-e.org

Fonte: http://www.wikiart.org/en/mary-cassatt

Figura 38 - Imagens comparativas: A Cortesã Hinazuru. Kitagawa Utamaro, 1794 e A Carta, Mary Cassatt, c. 1890

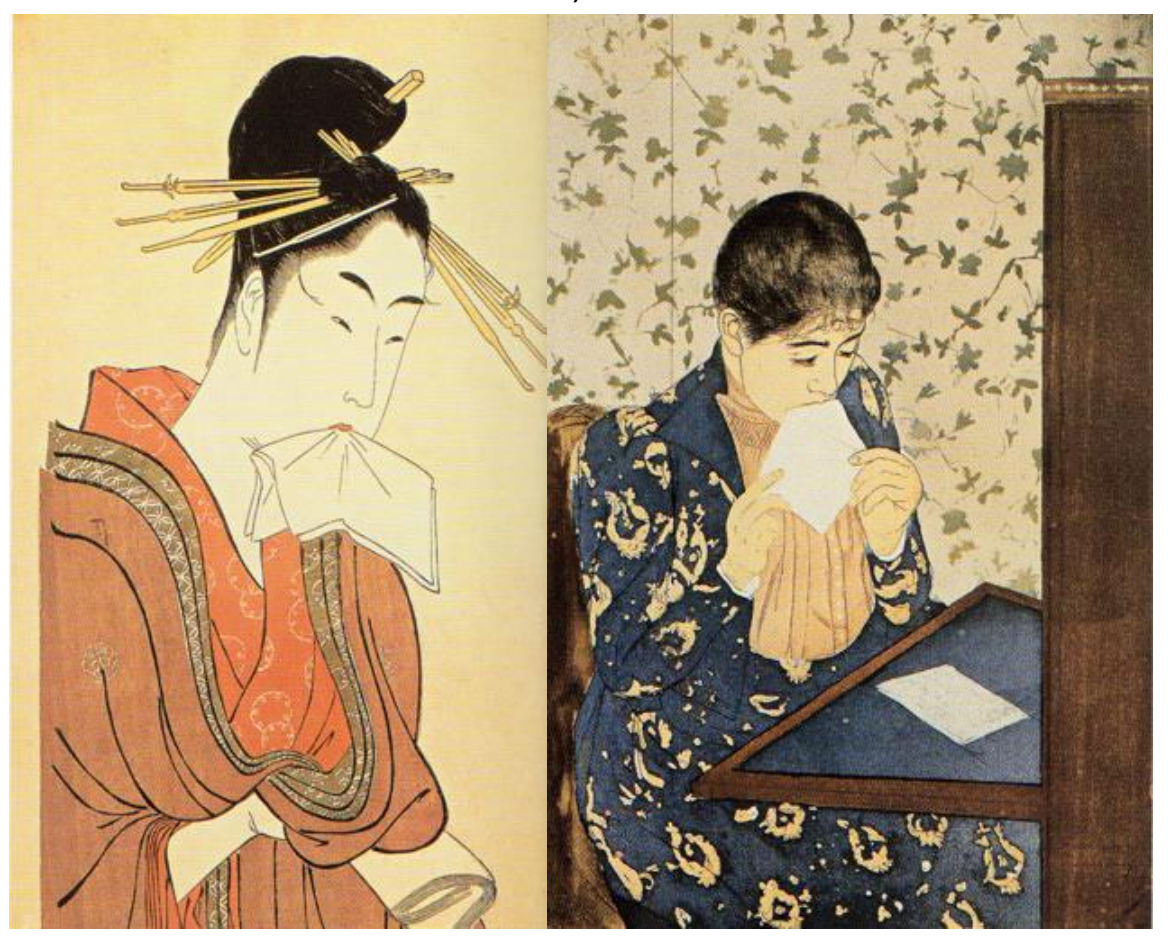

Fonte: http://ukiyo-e.org/image

Fonte: http://www.marycassatt.org 
O nu de Mary Cassatt, assim como o nu de Degas, não se relaciona com o erótico, mas se comporta como mais um elemento composicional na imagem (Figura 39).

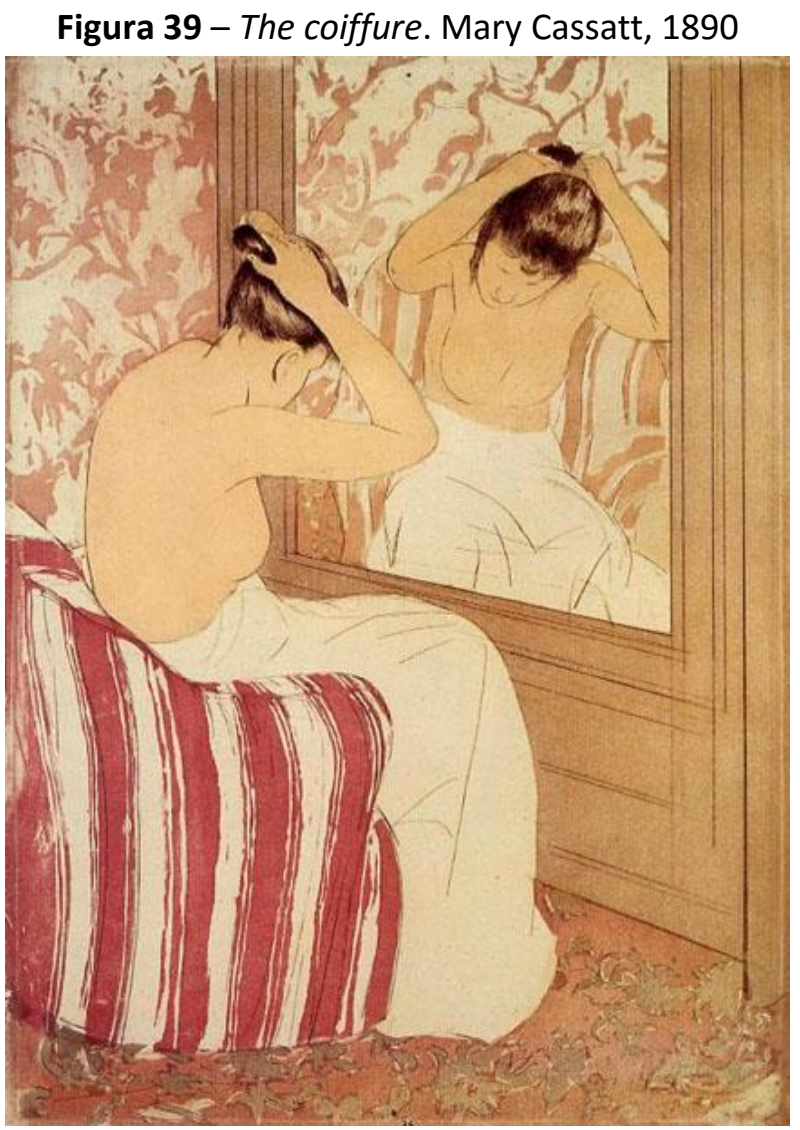

Fonte: http://hoocher.com/Mary_Cassatt/Mary_Cassatt.htm

De acordo com Breuer (1994, p. 65), as temáticas do ukiyo-e, mais do que nenhuma outra, "atraíram os artistas da era impressionista na busca de inspiração para sua própria revolução estilística". Os exemplos aqui expostos são pouco comparados à fecundidade do fenômeno que foi o Japonismo na temática dos pintores europeus; porém, são amostras suficientes para comprovar que o ukiyo-e confirmou e tornou válido o propósito de representar cenas mais íntimas e próximas à realidade humana.

Por meio do olhar único dos artistas e do propósito de cada um deles, constata-se que a representação da arte japonesa se revelou de forma heterogênea nas obras ocidentais, de modo que se torna tanto como forma de expressão de contemporaneidade, quanto como uma aliada ao desenvolvimento de uma nova abordagem, ou, até mesmo, com propósitos em simultâneo. 


\subsubsection{A composição pictórica}

A composição pictórica impressionista se configurou como realmente revolucionária e nova para a arte europeia; abriu e marcou o caminho para a formação de uma estética modernista. Segundo Schapiro (2002), tratou-se de uma ruptura que só foi possível com a ajuda de fortes influências, que ofereceram e despertaram a criação de novas concepções na arte.

O fato de a arte japonesa comumente representar a figura fora do centro, apresentouse como um aspecto totalmente revolucionário aos olhos europeus baseados em um renascimento ideal no qual as figuras deveriam estar dispostas no centro exato da imagem, refletind o o formulário hierárquico social central que determinou a fixação desse conceito. No Ocidente, a simetria, equilíbrio e ordem, representados por proporções regulares e perspectivas científicas de foco único, estavam, portanto, intimamente relacionados com a beleza, aspectos esses que acompanharam a representação plástica renascentista e que, por quatro séculos, satisfizeram as necessidades figurativas da civilização ocidental (GOMBRICH, 1993).

Como exemplo dessa multissecular tradição, há, entre inúmeras outras, as obras do italiano Rafael Sanzio (1483-1520). Em o Casamento da Virgem (Figura 40), Dewil (2007) relata ser possível observar claramente, além da temática digna, a básica simetria, definidas por um eixo central que divide a superfície pavimentada em duas partes, alinhando-se à ação principal da cena. A descoberta do ponto de fuga pelos artistas era ativada com a finalidade de se criar uma imagem coerente, que transmitia uma sensação tridimensional, reforçada por efeitos "atmosféricos": as cores são mais fortes em primeiro plano, mas vão despencando conforme a distância. É possível perceber até mesmo sua preocupação com a simetria na proporção das cores, em sua busca do equilíbrio perfeito. 
Figura 40 - Casamento da Virgem. Rafael Sanzio, 1504

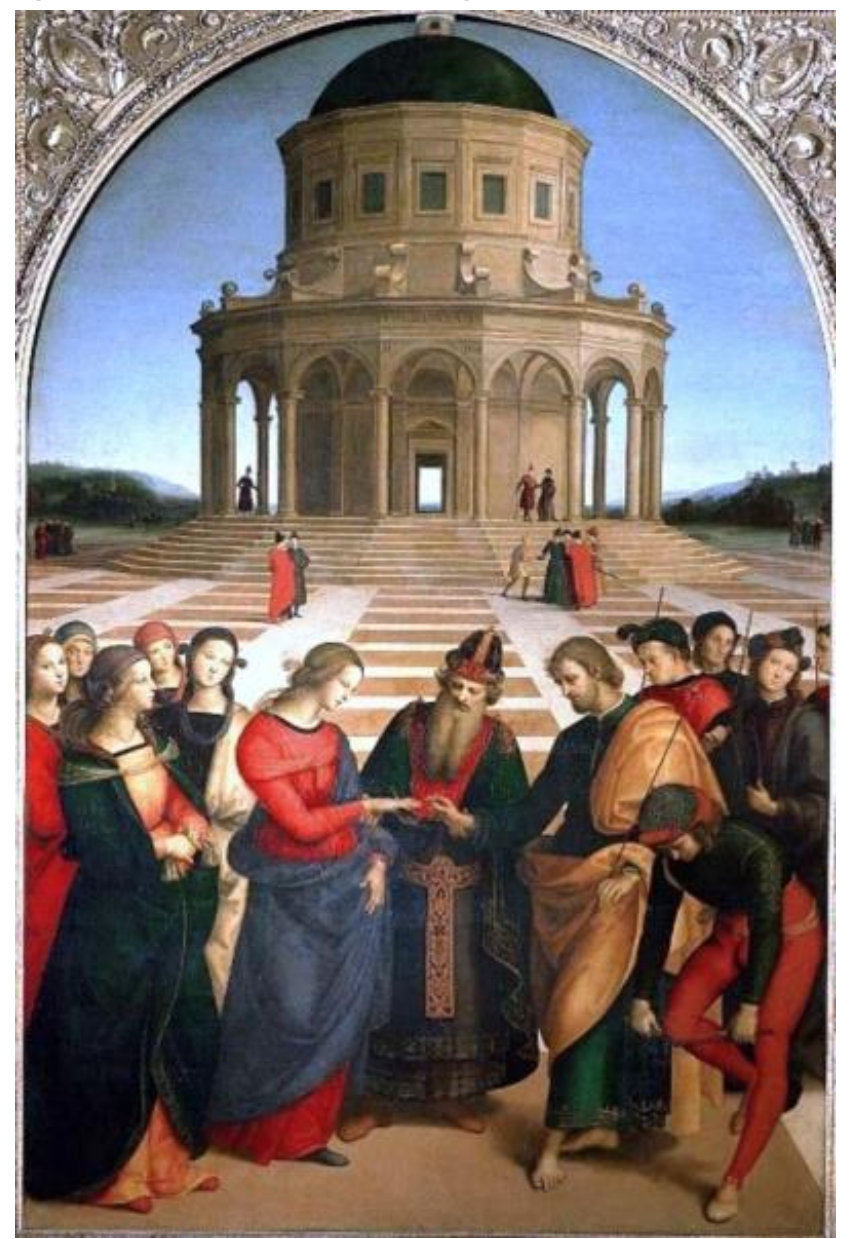

Fonte: http://www.wga.hu

Essa proporção também é visível na obra de Antonio e Piero del Pollaiuolo (respectivamente 1433-1498 e 1443-1496), O Martírio de São Sebastião (Figura 41). O retábulo representa o santo amarrado em um poste, enquanto seis carrascos o cercam, formando um desenho regular triangular. A simetria, apesar de matematicamente fascinante, remete às sensações de frieza, inflexibilidade e estaticidade, como provavelmente percebeu o artista, que busca amenizar a sensação representando os carrascos em diferentes ângulos. Porém, Gombrich (1993) aponta que, devido a cada carrasco corresponder a uma figura semelhante no lado oposto, faz com que o arranjo, tão claro e simétrico, torne-se quase rígido demais. 
Figura 41 - O Martírio de São Sebastião. Antonio e Piero del Pollaiuolo, 1475

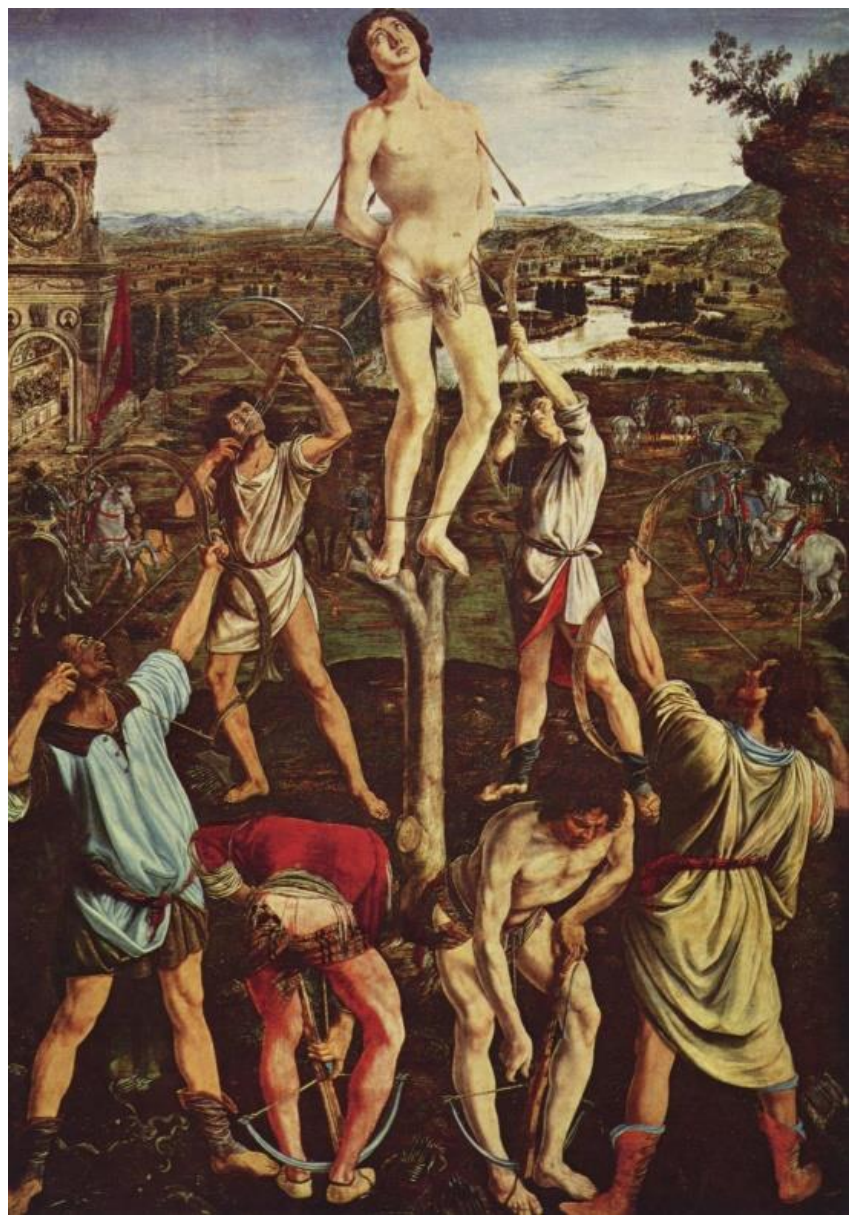

Fonte: http://www.nationalgallery.org.uk

Essa tradição de composição, estabelecida e tecida por séculos, os pintores do século XIX almejavam dela se desvincular. Causa surpresa o fato de encontrarem soluções no estrangeiro, em uma forma de arte popular desvalorizada. De acordo com Bell (2002), em sua tese de doutorado, a gravura japonesa pôde oferecer essa riqueza de dispositivos pictóricos porque se estabeleceu justamente como popular. Os mestres ukiyo-e, desvinculados das escolas oficiais e, portanto, de suas convenções e limitações, possuíram um leque mais alargado de ferramentas e processos à sua disposição para o fazer de sua arte. A inovação do ukiyo-e residiu exatamente na liberdade de selecionar e empregar dispositivos pictóricos diversificados simultaneamente.

Gompertz (2013) afirma que, em contraste com a arte europeia oficial, no qual a pintura, mediante o uso de sombras e gradações cromáticas tem como objetivo alcançar a solidez tridimensional, a bidimensionalidade do ukiyo-e, que o acompanha desde o seu aparecimento, passa a ser explorado com sucesso nas obras impressionistas. Já iniciado por 
Édouard Manet, esse componente da bidimensionalidade é perceptível na célebre obra de Claude Monet Impressão: Sol Nascente (Figura 42).

Figura 42 - Impressão: Sol Nascente. Claude Monet, c. 1875

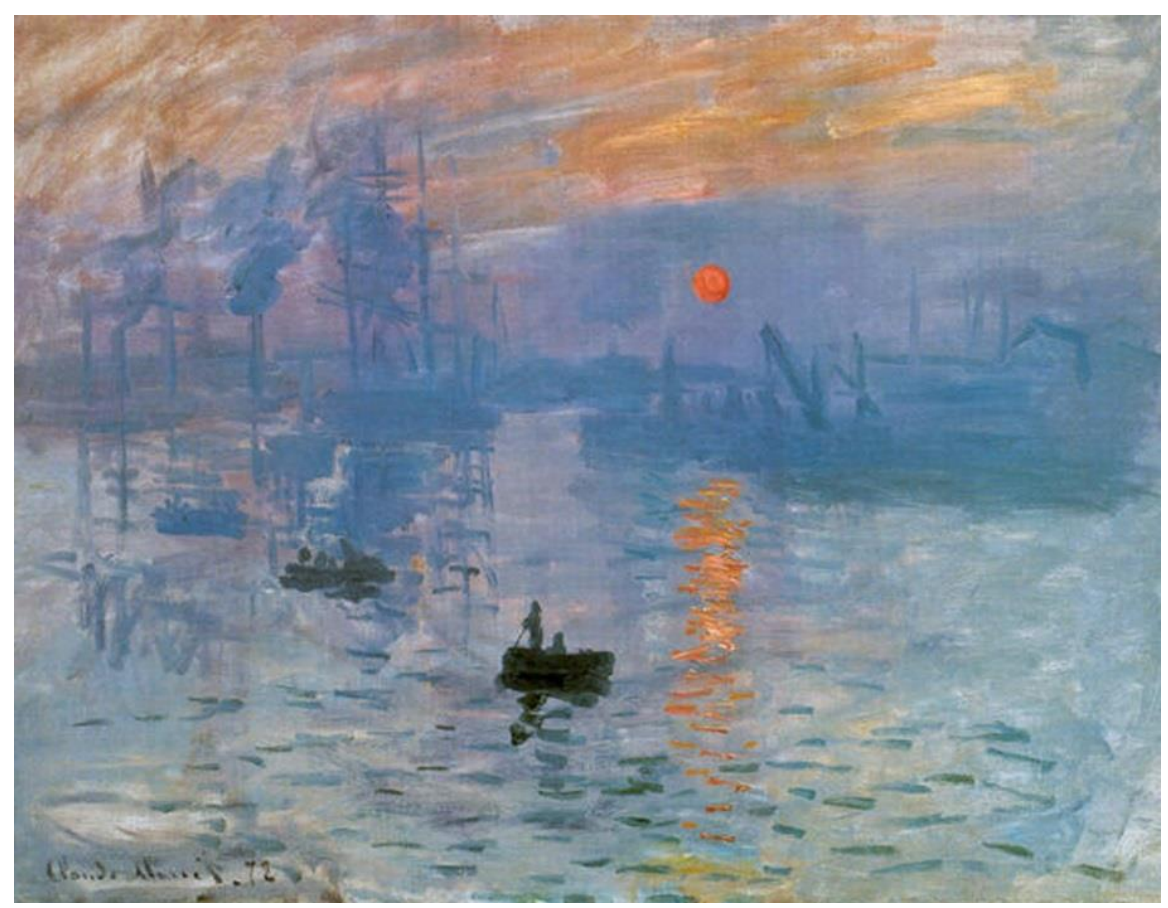

Fonte: http://www.intermonet.com

Para Ives (1979), a descentralização, que já se fazia presente na cultura estética japonesa, configurou-se também como uma conveniente solução aos formatos particularmente difíceis e verticalizados projetados para a decoração de pilares ou biombos dobráveis, tradição que teve início em 1700 (Figura 1 e Figura 43). Wichmann (2007) acrescenta que, esse aspecto alterou diretamente os princípios de composição ocidentais; com efeito, os impressionistas, libertos de qualquer convencionalismo ou preconceito, percebem que o deslocamento da figura não só agrega vivacidade como quebra o estaticismo já percebido na tradição ocidental.

Bell (2002, p. 150), acima referido, defende que

Os artistas do ukiyo-e eram sofisticados solucionadores de problemas espaciais, capazes de escolher entre uma variedade de modos diferentes, tanto para a representação do espaço tridimensional em imagens como para a disposição bidimensional da informação pictórica através do plano da 
imagem. Seu repertório era muito mais variado do que a que os artistas das escolas Tosa ou Kanō eram autorizados a empregar. Em alguns casos, os artistas aprenderam as convenções através das obras de artistas anteriores; em outros, aprendeu-os dentro de estúdios ou de escolas; em outras, aprenderam de seus contemporâneos; alguns exploraram ou desenvolviam dispositivos pictóricos criativos de forma independente. Além disso, eles usavam dispositivos espaciais com um senso de propósito: dispositivos pictóricos eram ferramentas que poderiam alcançar fins particulares pictóricos.

Figura 43 - Xilogravuras verticais de Suzuki Harunobu e Uchimasa. Período Edo
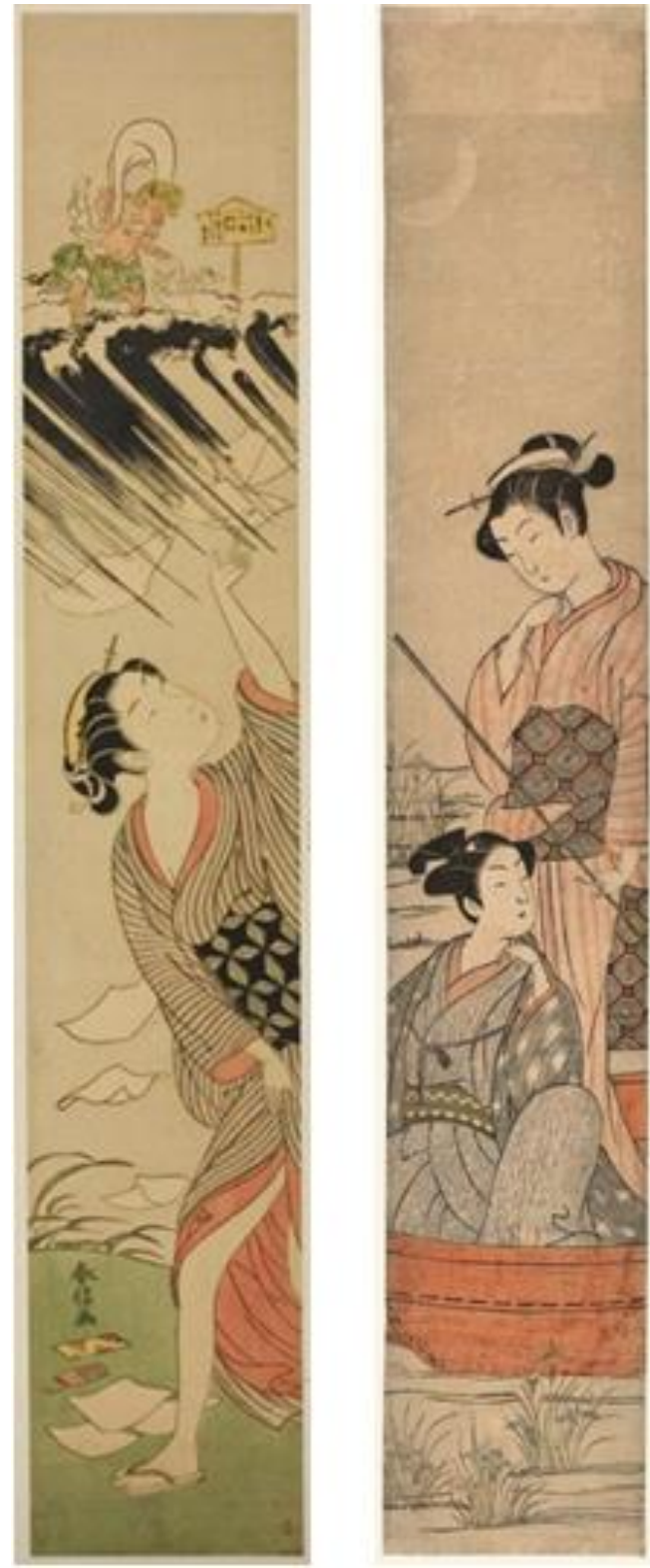

Fonte: http://ukiyo-e.org

Segundo esse mesmo autor, ao deslocar grande parte da composição ou das figuras para os lados, abre-se um espaço intervalar disponível que proporciona novas perspectivas 
para o horizonte. O vazio sempre foi primordial no pensamento estético do Oriente, que pressupõe não só a divisão, mas também a relação de conexão mais complexa entre os elementos da cena (Figura 44). Por volta de 1871 Claude Monet descentraliza sua composição na obra O Tâmisa abaixo de Westminster (Figura 45) assim como os mestres ukiyo-e, propiciando tensão emocional à cena.

Ainda de acordo com Bell (2002, p. 153)

a preocupação dos artistas ukiyo-e com o campo espacial "vazio", indica tanto uma preocupação especial e permanente com a questão do arranjo espacial, como um reconhecimento agudo das formas e as relações de componentes pictóricos podem gerar entendimentos mais complexos e mais sutis do que tendem a gerar os próprios objetos.

Figura 44 - Composição assimétrica de Utagawa Hiroshige

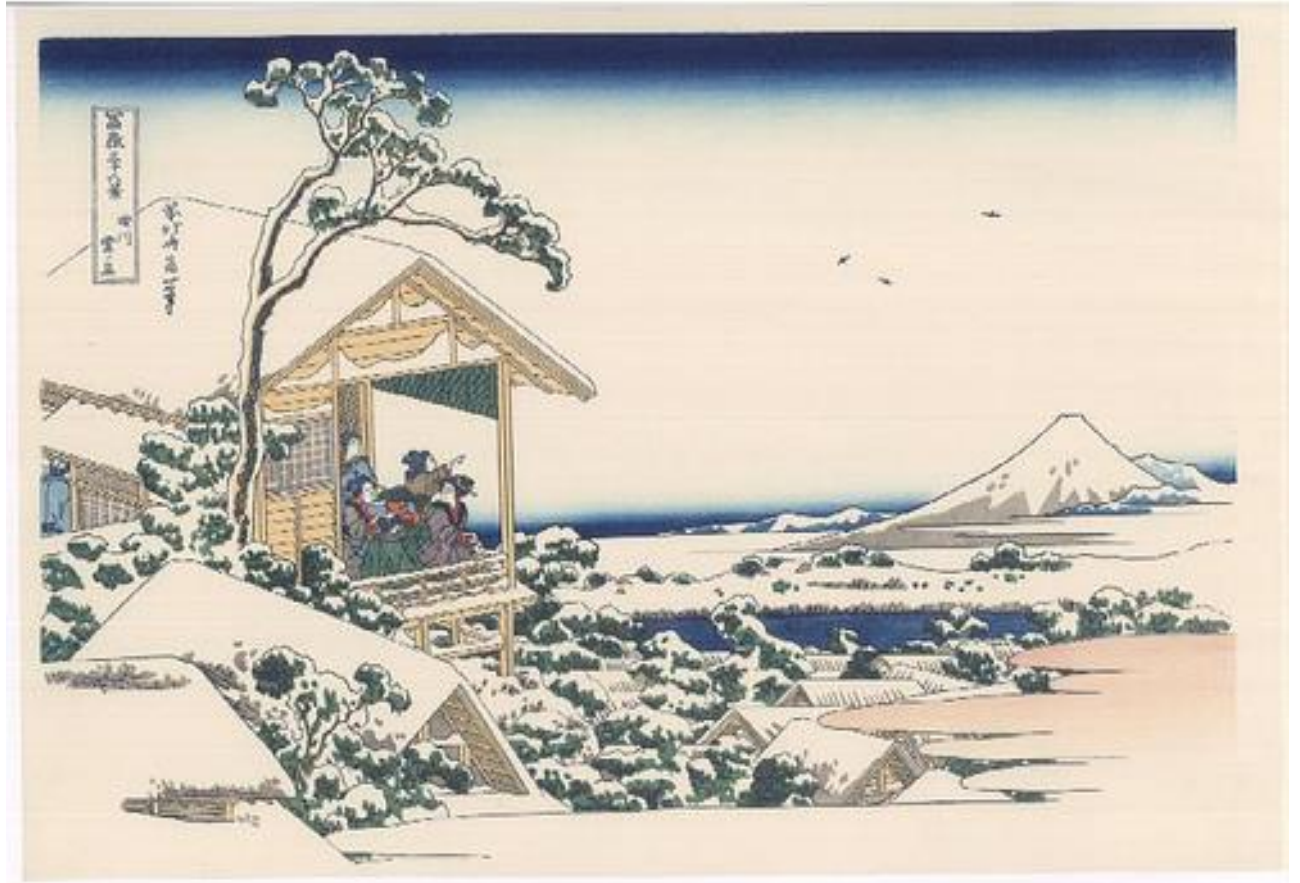

Fonte: http://www.ukiyo-e.org 
Figura 45 - Assimetria em O Tâmisa abaixo de Westminster. Claude Monet, c. 1871

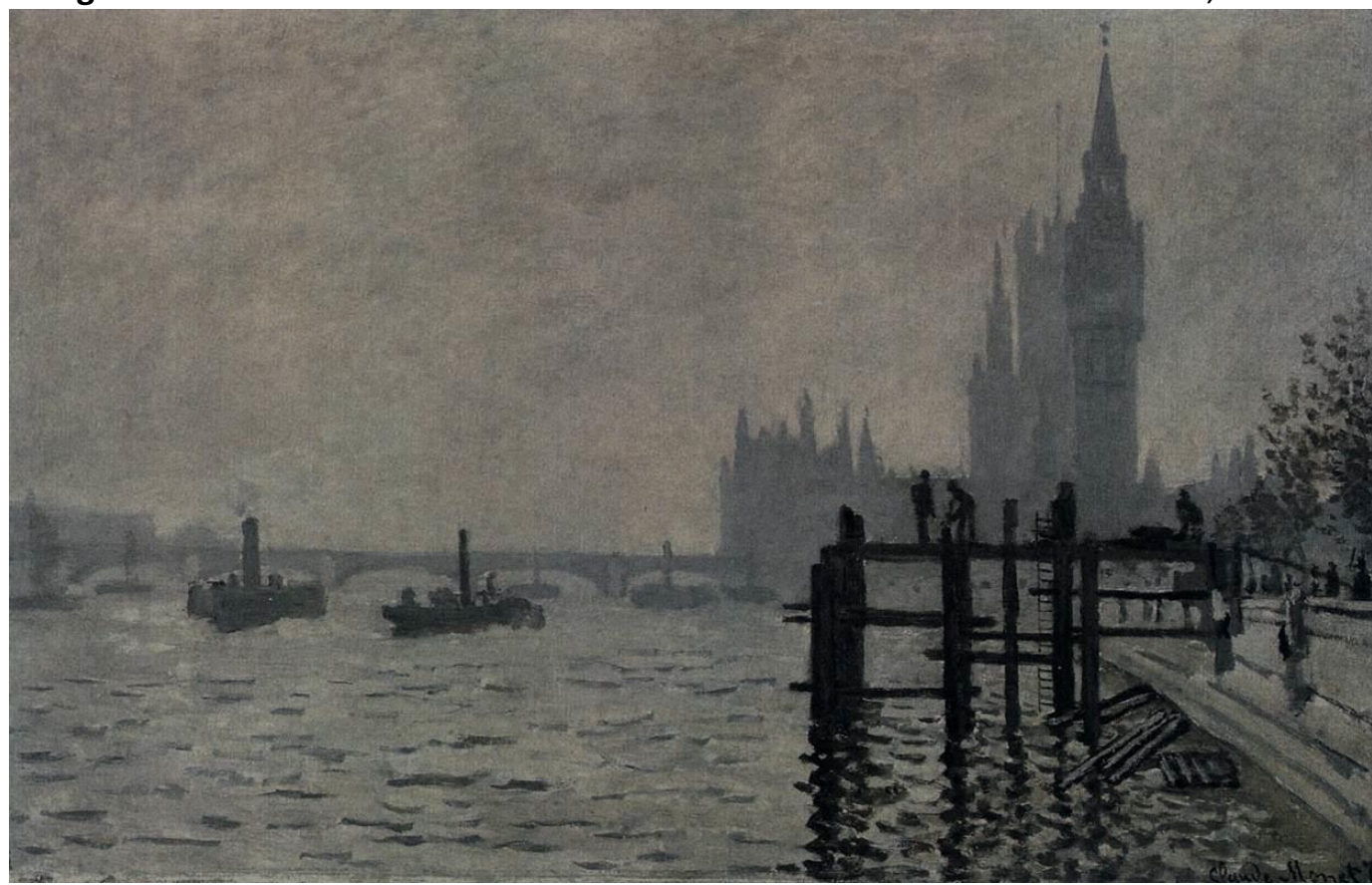

Fonte: http://www.nationalgallery.org.uk

O historiador de arte Ernst Gombrich (1982, apud McMANUS, 2005) demonstrou, com simples desenhos comparativos ${ }^{4}$ (Figura 46), o sentido de movimento que a descentralização traz consigo. Porque o barco não se encontra fixado no centro da composição, incorpora-se a sensação de dinamismo e efemeridade que os impressionistas tanto almejavam retratar, em contraste com a impressão de inatividade que existe com o barco posicionado ao centro.

\footnotetext{
${ }^{4}$ Uma vez que os barcos na imagem original (a) não são iguais, as imagens em (b) e (c) foram manipuladas de modo que os barcos ficaram idênticos.
} 
Figura 46 - Estudo de Ernst Gombrich

a.
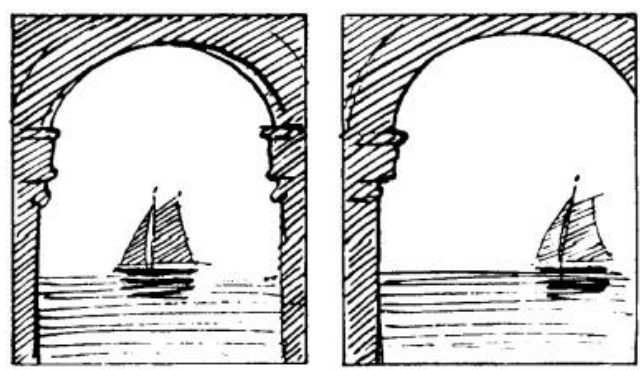

b.
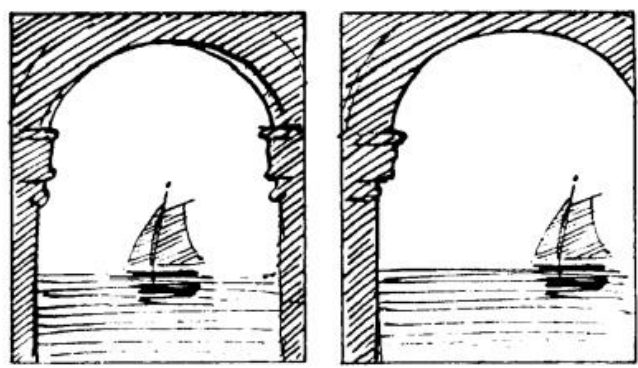

c.
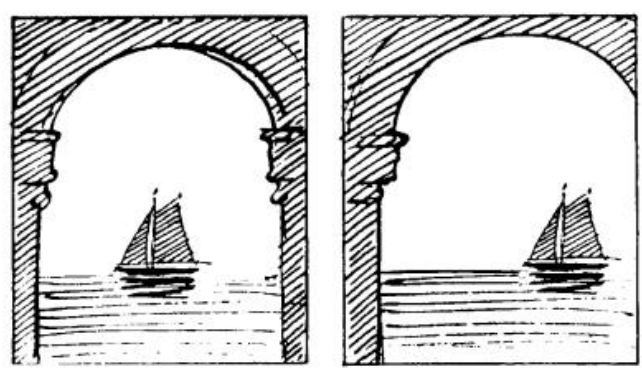

Fonte: http://www.cultorweb.com

As gravuras ukiyo-e também não hesitavam em mostrar a figura humana ou qualquer outra drasticamente cortadas. De acordo com Gombrich (1993, p. 417), esse "arrojado desdém por uma regra elementar da pintura europeia exerceu grande efeito sobre os impressionistas", de forma a questionar o porquê da necessidade de a pintura sempre mostrar o todo ou uma parte relevante de cada cena.

Wichmann (2007) avalia que esse aspecto, conhecido como "composição cortada", ou "trancamento", configura-se provavelmente como o mais relevante aspecto compositivo apresentado aos impressionistas, de modo que foram muito poucos os que não o adotaram.

Mediante a abreviação estereotipada dos objetos, subjetivada pelo olhar do artista, eles conseguem comunicar a impressão efêmera de um momento, inserindo um imediatismo visual à cena. Ao obscurecer parte de uma figura reconhecida, o espectador tende a completála, codificá-la em sua imaginação, de modo que esse processo se torna também uma questão 
da experiência e da consciência coletiva do observador. Essa interação entre o espectador e a obra analisada cria um valor de confiança, pois é necessária a comunhão da mente do criador e do observador para que a apreciação da arte aconteça (LAMBOURNE, 2005).

Nesse momento os artistas europeus provavelmente compreenderam de forma definitiva que o seu modus operandi anterior, absorto em técnicas, ignorava exatamente esse vínculo, de modo que, a partir desse momento, a composição deixa de ser passiva para se tornar dinâmica. Nesse sentido, a afirmação de Wichmann (2007, p. 243): “Os pintores europeus aprenderam com os mestres japoneses do ukiyo-e que o objeto truncado pode ser muito mais importante do que aqueles cujas formas estão completamente visíveis".

Monet utilizou abundantemente esse princípio ao longo de sua carreira, como pode ser observado nas obras da Figura 45 e da Figura 50, confirmado também em suas palavras para o Duque de Treviso, em 1920 (REYES, 2014): “O que nós apreciamos sobretudo no Ocidente foi a forma corajosa do Oriente em definir seus temas. Essas pessoas nos ensinaram a compor de forma diferente - não há dúvida alguma sobre isso".

Apresentam-se a seguir alguns exemplos de obras orientais e ocidentais com o tema barco truncado: 
Figura 47 - Mulher no barco colhendo flores de lótus. Harunobu, 1765

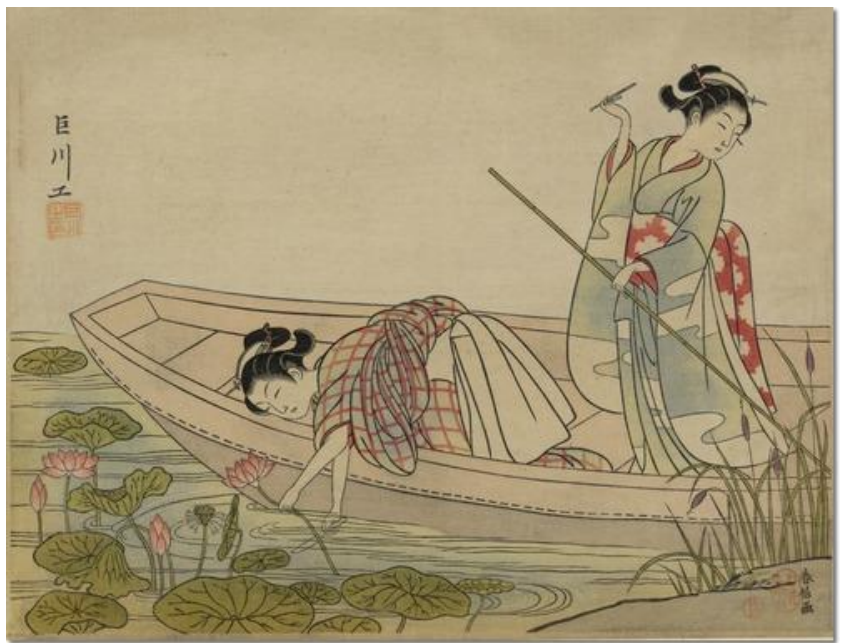

Fonte: http://ukiyo-e.org

Figura 48 - Passeio de Barco. Édouard Manet, 1874

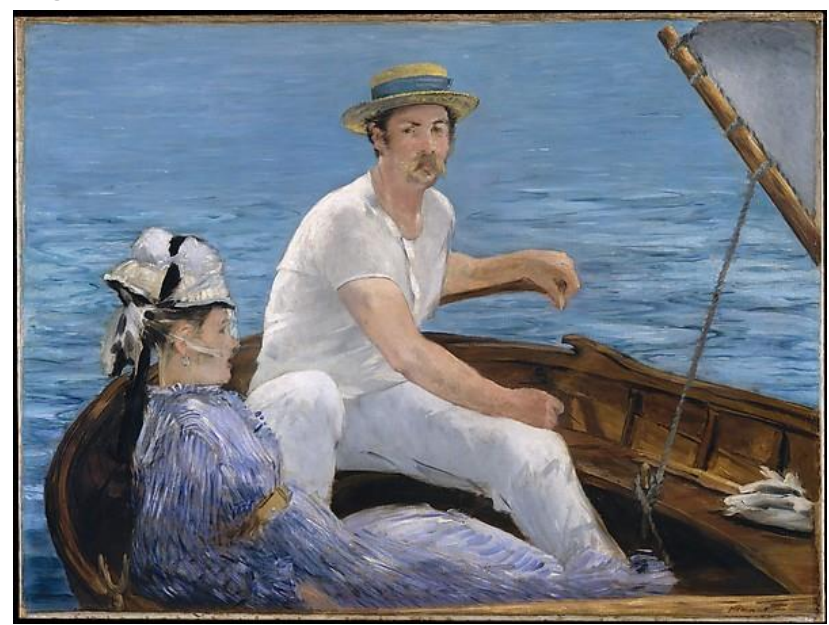

Fonte: http://fineartamerica.com

Figura 49 - Alimentando os patos. Mary Cassat, 1895

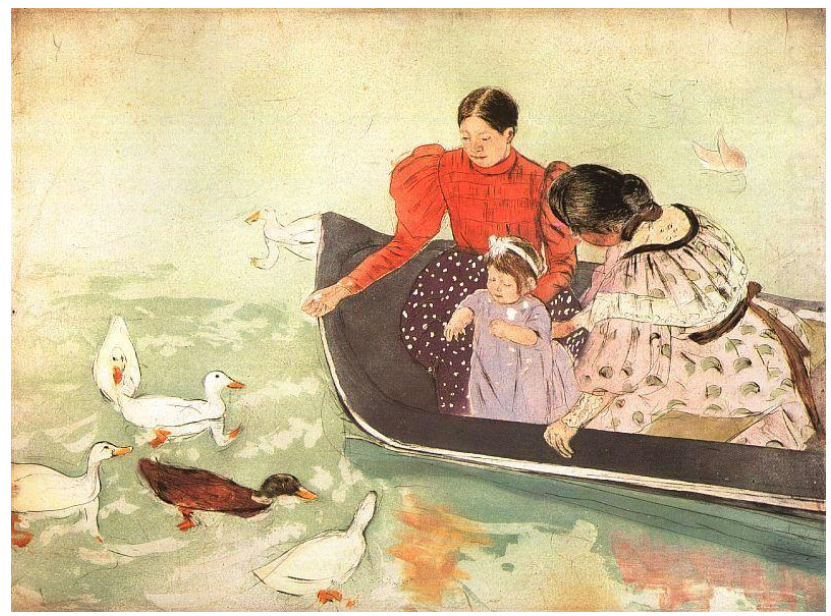

Fonte: http://www.wikiart.org/en/mary-cassatt/feeding-the-ducks-1895 
Figura 50 - O Barco no Epte. Claude Monet, 1890

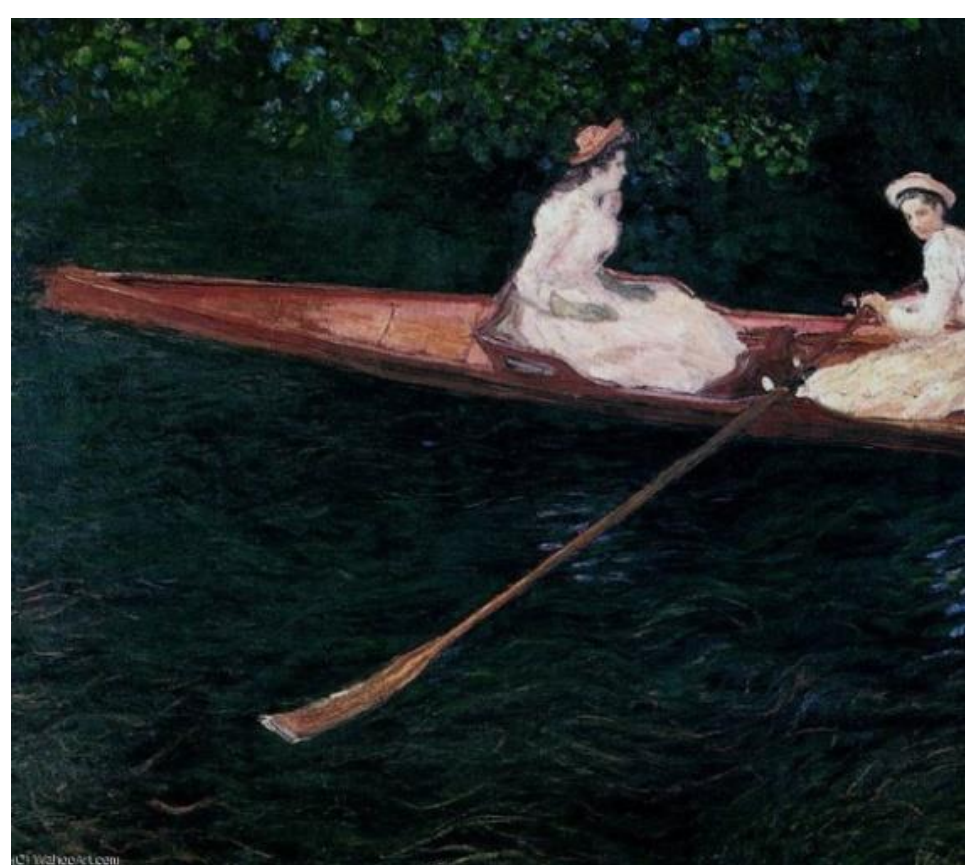

Fonte: www.claudemonetgallery.org

O truncamento foi levado mais adiante por outros artistas de outros movimentos, como pelo pintor pós-impressionista Henri de Toulouse Lautrec (1864-1901), que exagerou nessa técnica em níveis tão dramáticos "ao ponto de serem considerados absurdos" (WICHMANN, 2007, p. 247). A linguagem do pôster litográfico Jane Avril (Figura 58), que dispensa qualquer concepção de espaço realista, distorce o ponto de visão do observador de forma tão notável que chega à deformação.

Muitos aspectos de seu trabalho, como a ausência de profundidade, as formas simplificadas, as grandes áreas de cores chapadas, o delineado preto, a diagonalidade, entre outros, são facilmente identificados nas figuras abaixo. Essas características determinaram seu estilo pessoal e derivam da ampla exploração de possibilidades percebidas nas gravuras japonesas. 
Figura 51 - Pôster Jane Avril. Henri de Toulouse Lautrec, 1893

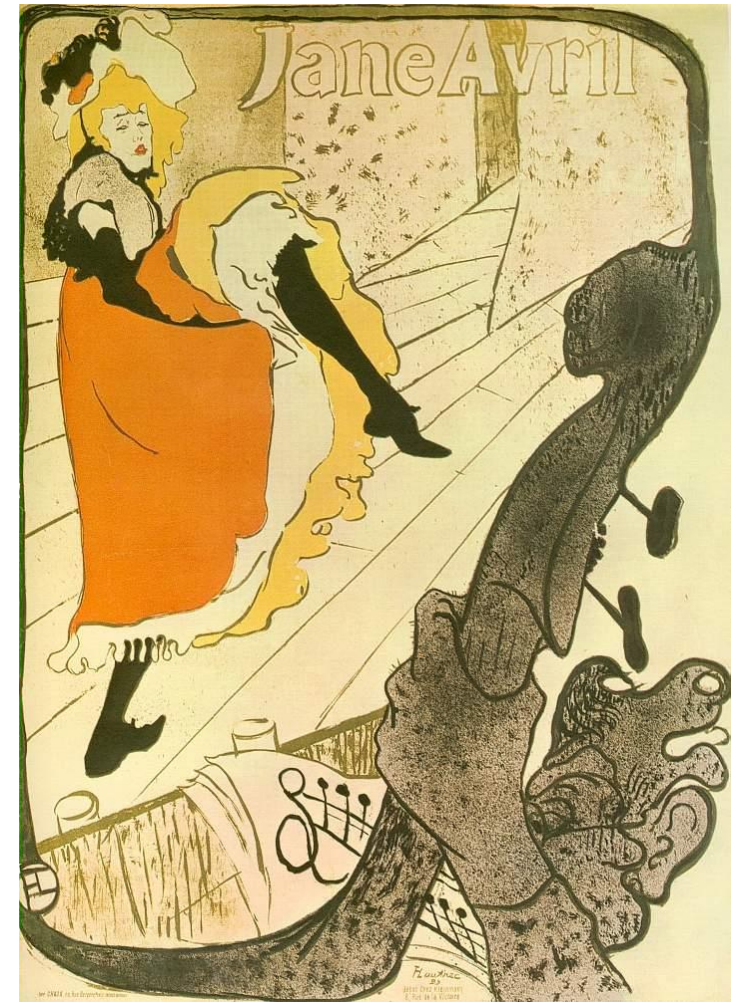

Fonte: http://en.wikipedia.org/wiki/Jane_Avril

Figura 52 - Pôster Le Divan Japonais. Henri de Toulouse Lautrec, 1892

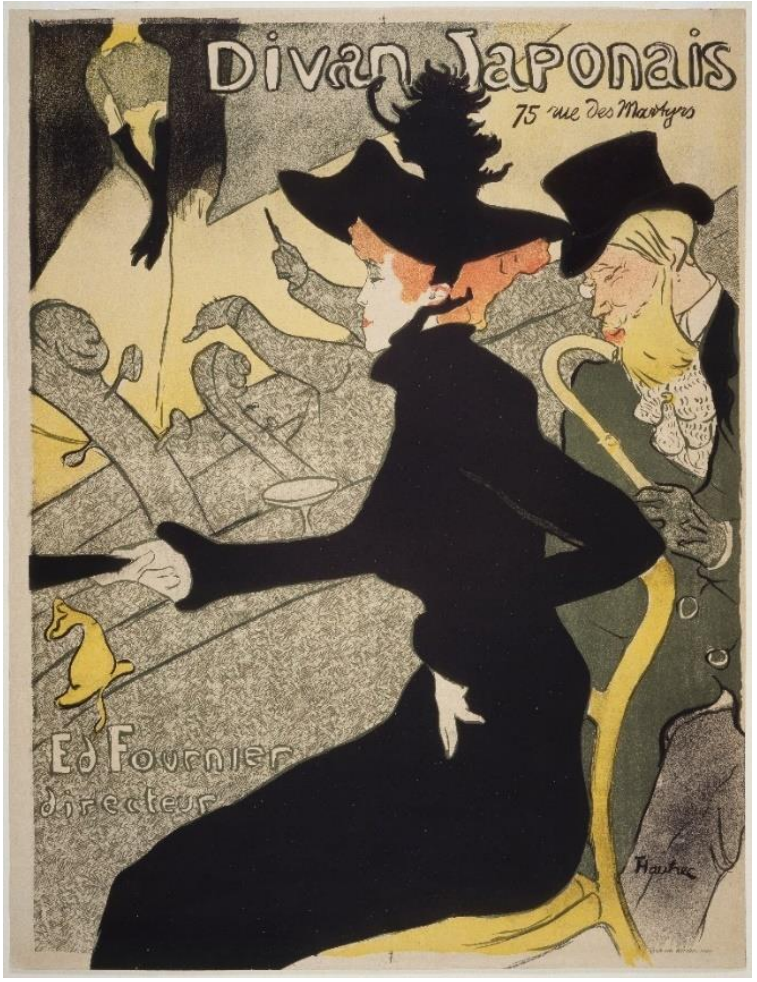

Fonte: http://www.metmuseum.org 
Degas, de igual modo, soube utilizar com maestria os aspectos de composição diferenciados dos xilógrafos japoneses para dar uma nova abordagem à sua própria arte. Nas suas diversas obras com o tema de bailarinas (Figura 53, Figura 55 e Figura 56), ele incorpora o truncamento a fim de alcançar sua ambição artística, que era representar o momento em sua exata verdade, rompendo com o imobilismo. Em suas obras, não era a dança em si que o interessava, mas, sim, o comportamento do corpo no espaço (IVES, 1979).

Figura 53 - A aula de Balé. Edgar Degas, entre 1871 e 1874

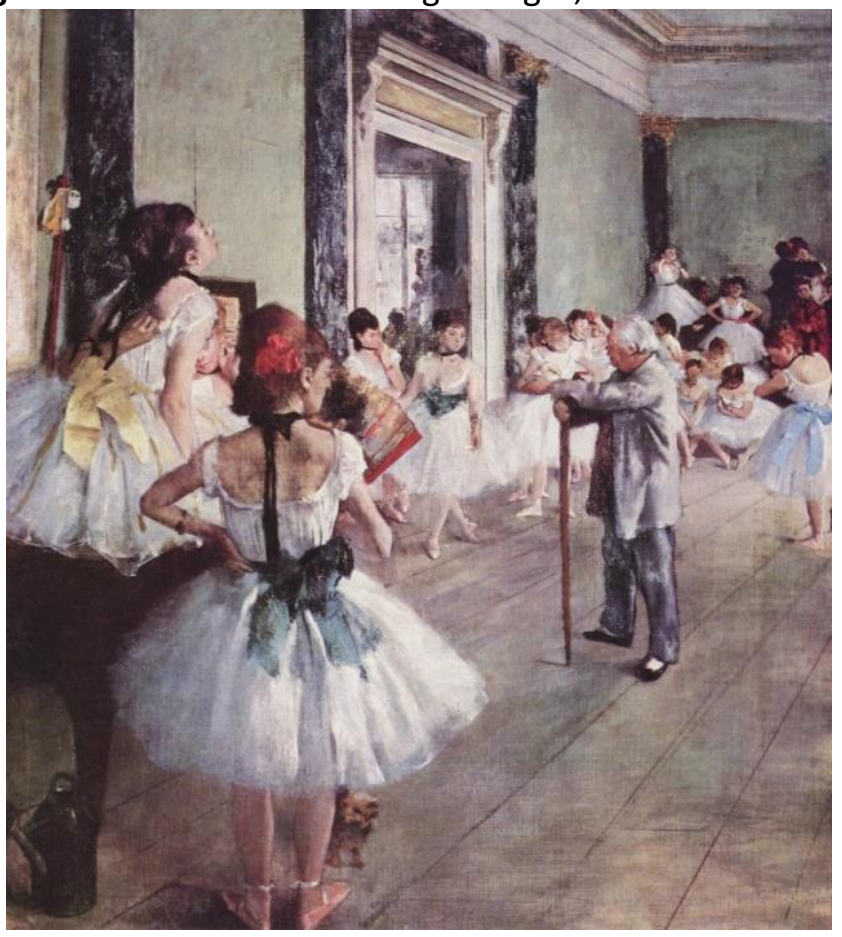

Fonte: http://www.histoire-image.org

A intenção de Degas, como pode ser observado na obra $A$ aula de Balé (Figura 53) é comunicar um momento fugaz por ele congelado no tempo. Cada personagem se ocupa com as suas percepções e pensamentos; algumas retratadas de forma incompleta, de modo a reforçar o efeito voyeurístico. As poses são visivelmente variadas, algumas absortas diante de seu professor e, outras, como no canto esquerdo, desatenta, coça as costas com o queixo erguido em sinal de momentâneo alívio.

Gompertz (2013), ainda em A aula de Balé, destaca ser possível observar que Degas arranjou a composição em uma faixa diagonal, que corre do canto inferior esquerdo ao canto superior direito, assim como em A Estação de Otsu, de Hiroshige (Figura 54). Favorece também, em consonância com as gravuras nipônicas, o ponto de vista elevado (como se um 
pássaro estivesse a observar o momento), e pela perspectiva exagerada, de forma a animar o que de outro modo seria uma cena estática. Devido à incorporação desses elementos, muitas outras obras de Degas se assemelham à captação de uma fotografia.

Figura 54 - Estação de Otsu, da série Cinquenta e três estações de Tokaido. Utagawa Hiroshige, c. 1848

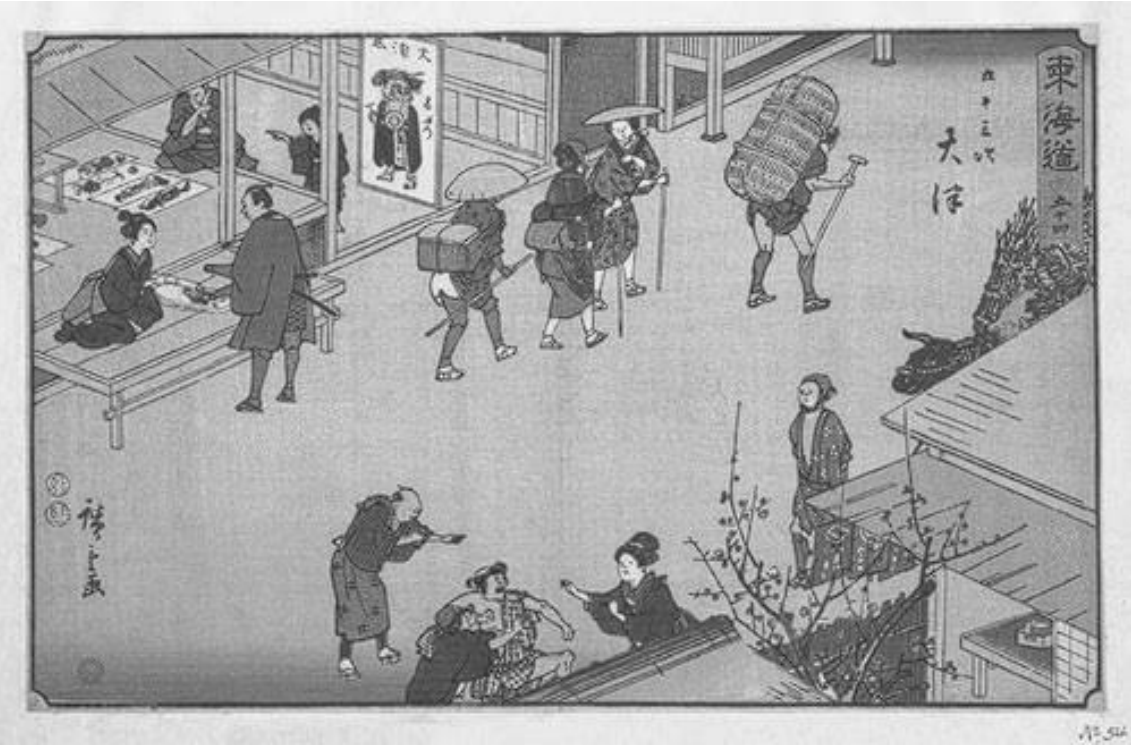

Fonte: http://www.metmuseum.org/toah/works-of-art/JP804

Figura 55 - A estrela. Edgar Degas, c. 1877

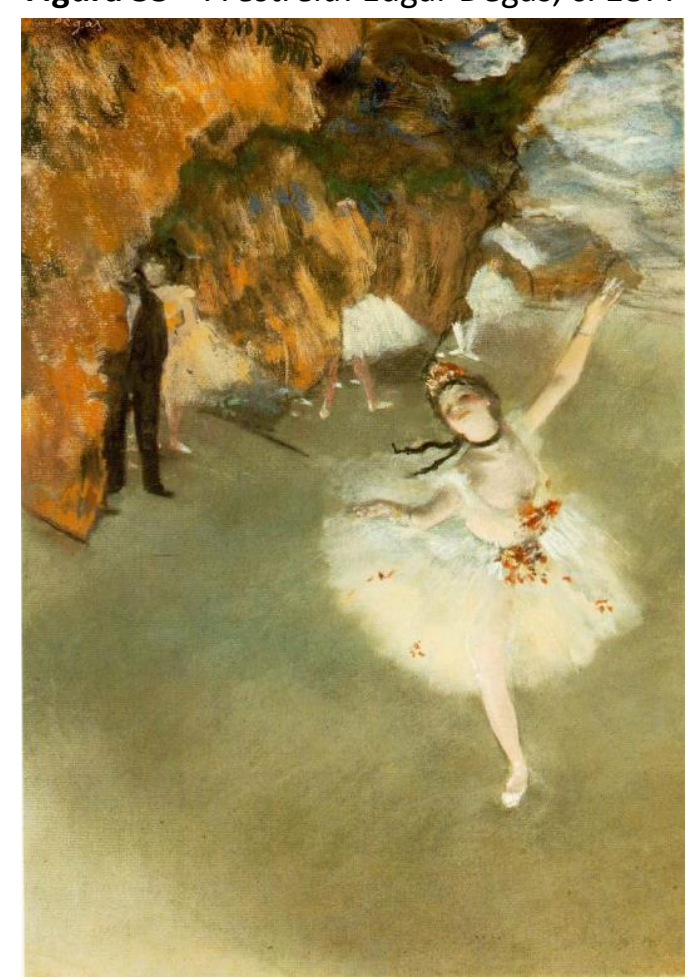

Fonte: http://www.histoire-image.org 
Figura 56 - Dançarinas subindo uma escada. Edgar Degas, 1886

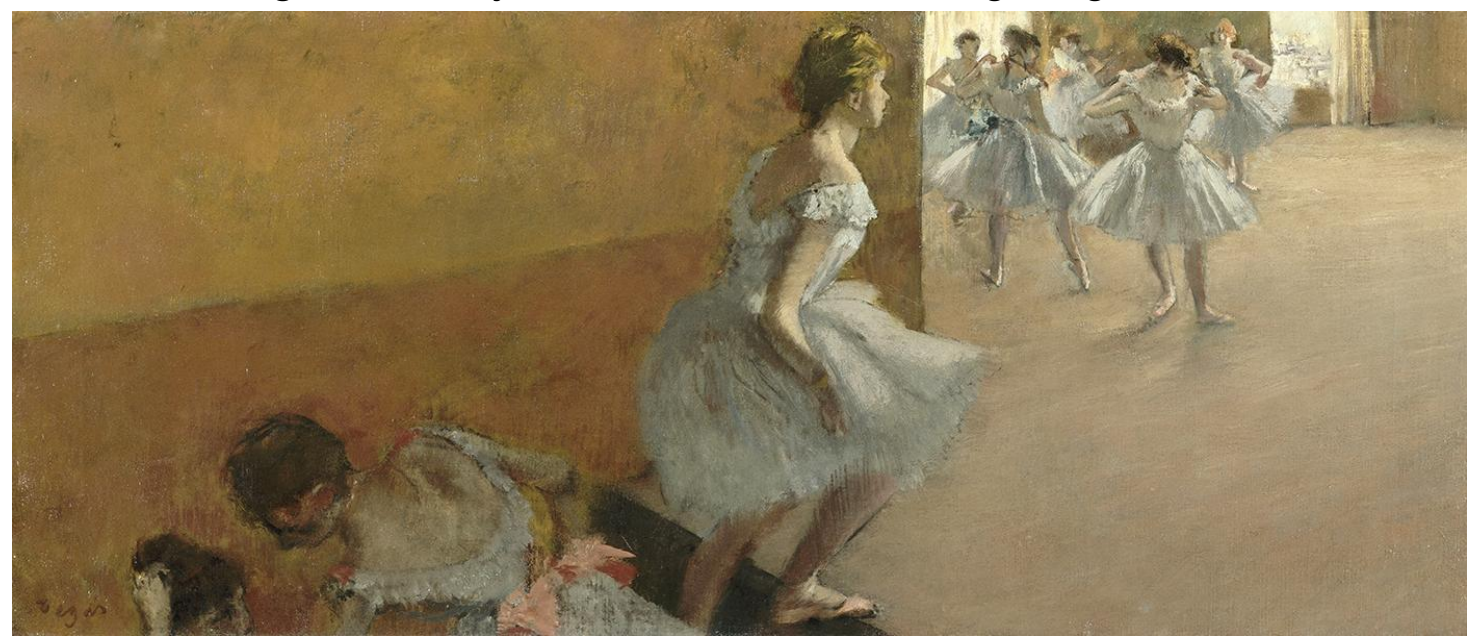

Fonte: http://www.histoire-image.org

Muitos estudiosos abordam exatamente a influência da fotografia nas cenas impressionistas, o qual, nesse contexto, surge como outro aspecto da modernidade, desenvolvendo-se ao longo do século XIX. Porém, Schapiro (2002, p. 179) afirma que os fotógrafos possuíam convenções que envolveriam a pose, a iluminação e a composição emprestadas pela arte acadêmica, "que combinava a busca do detalhe minucioso com o gosto pela solenidade da postura fixa".

Sanchez e Almarza (2008) ainda defendem que é pouco provável que essa influência da fotografia tenha atingido níveis importantes na determinação da composição de Edgar Degas, pois alegam que os efeitos instantâneos de uma fotografia pouco têm a ver com o planejamento e o estudo minucioso que esse artista construía, resultante de profundas pesquisas em centenas de esboços preliminares, muitos deles derivados dos rascunhos de Hokusai. Ainda de acordo com esses mesmos autores, os efeitos da assimetria estudada que Degas tanto admirava são anteriores à popularização desse recurso na arte fotográfica, de modo que é mais provável que ele, um dos primeiros adeptos da câmera fotográfica, antecipasse sua evolução.

De acordo com Wichmann (2007, p. 26), as gravuras japonesas "deram aos impressionistas novas ideias sobre poses e ações particulares, os quais são atraídos em incorporar em suas obras como uma parte vital da composição". Em contraste com a tradição ocidental, que privilegiava somente as posturas mais formais, Degas lança-se às poses casuais e inusitadas, até mesmo estranhas, "para Ihe dar o aspecto de um gato ou uma figura 
grotesca" (SCHAPIRO, 2002, p. 156), como se estivessem sendo observadas sem que percebessem. Pelas de análises de inúmeras xilogravuras pesquisadas, numa delas, foi possível constatar que, Banho de água gelada de Utamaro possui semelhanças inegáveis com a obra Banho Matinal de Degas quando dispostas lado a lado (Figura 57).

Figura 57 - Imagens comparativas: Banho na água gelada. Kitagawa Utamaro, 1799 e Banho matinal.

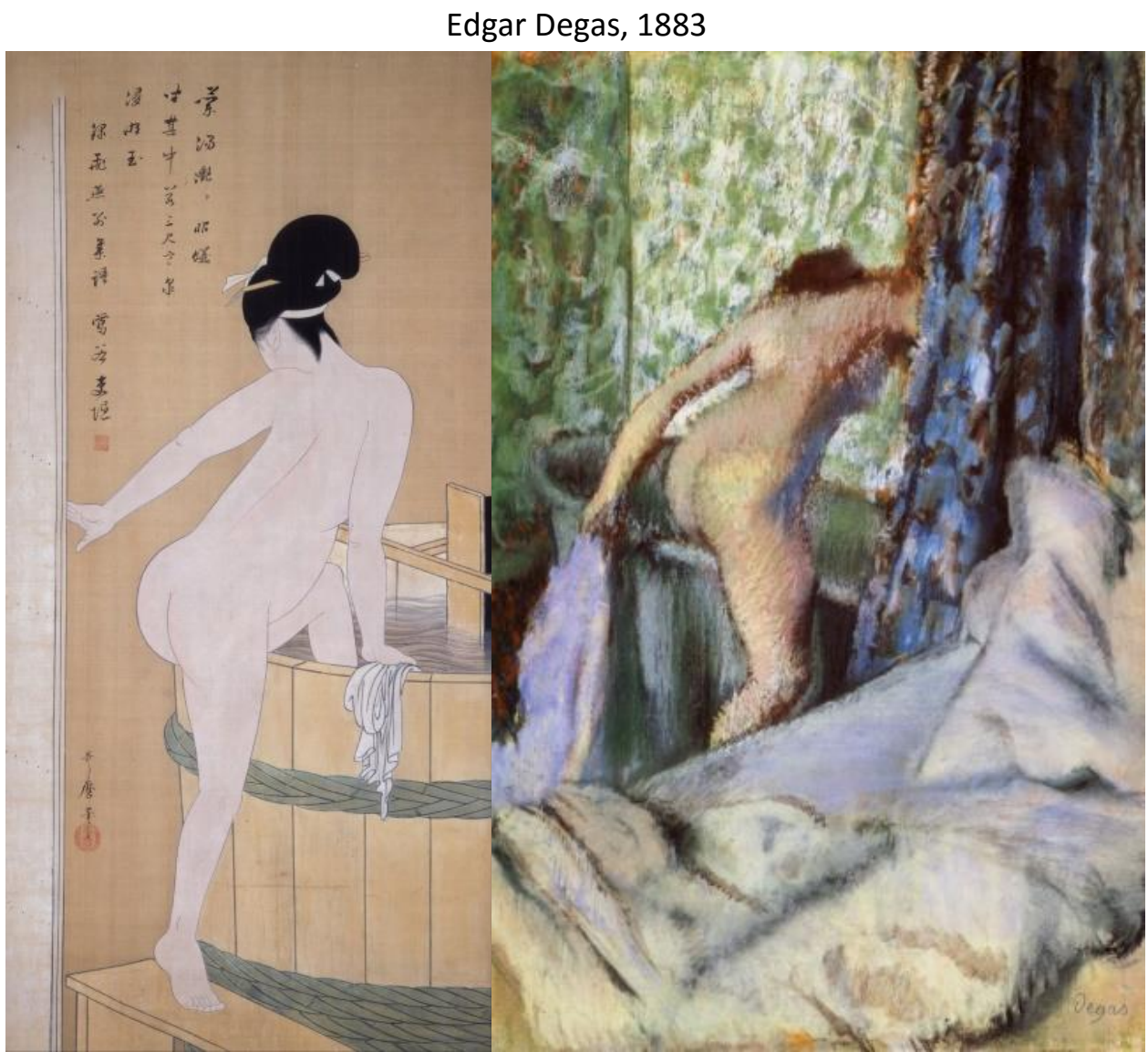

Fonte: http://commons.wikimedia.org/wiki

Fonte: http://www.wikiart.org/en/edgar-degas/the-morning-bath-1883

Os esboços dos mestres japoneses mostraram a Degas uma maneira inovadora de representar bidimensionalmente o movimento implícito. Seus inúmeros esboços de linhas simples descrevem o corpo humano em posturas altamente instáveis, as quais fazem parte de uma sequência de movimentos (Figura 58). Motivação similar é expressa em seus estudos (Figura 59 e Figura 60) e, consequentemente, em suas obras. 
Van Gogh já mencionara: “Os japoneses desenham rápido, muito rápido, como um relâmpago, porque seu raciocínio é mais refinado, seus sentimentos mais simples" (RUGER, 2009).

Figura 58 - Manga de Katsushika Hokusai

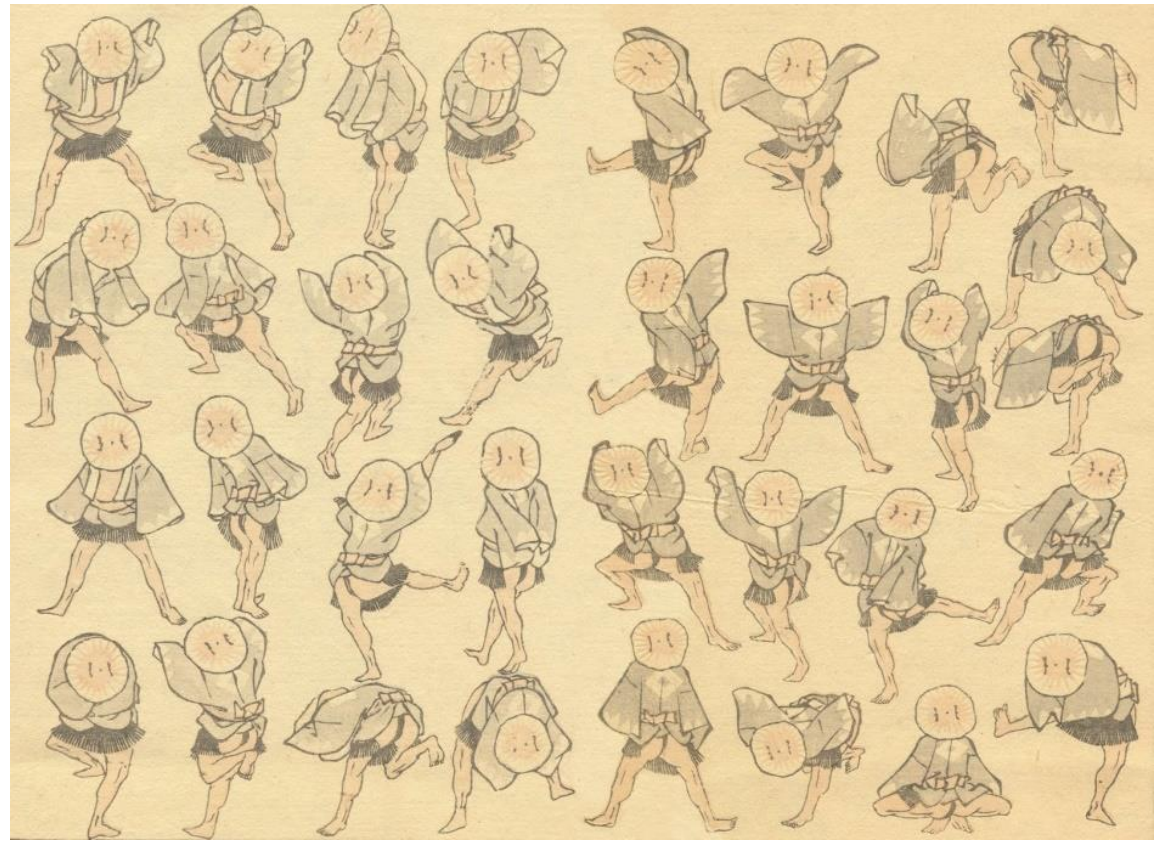

Fonte: http://ukiyo-e.org

Figura 59 - Esboços e estudos de pose de Edgar Degas

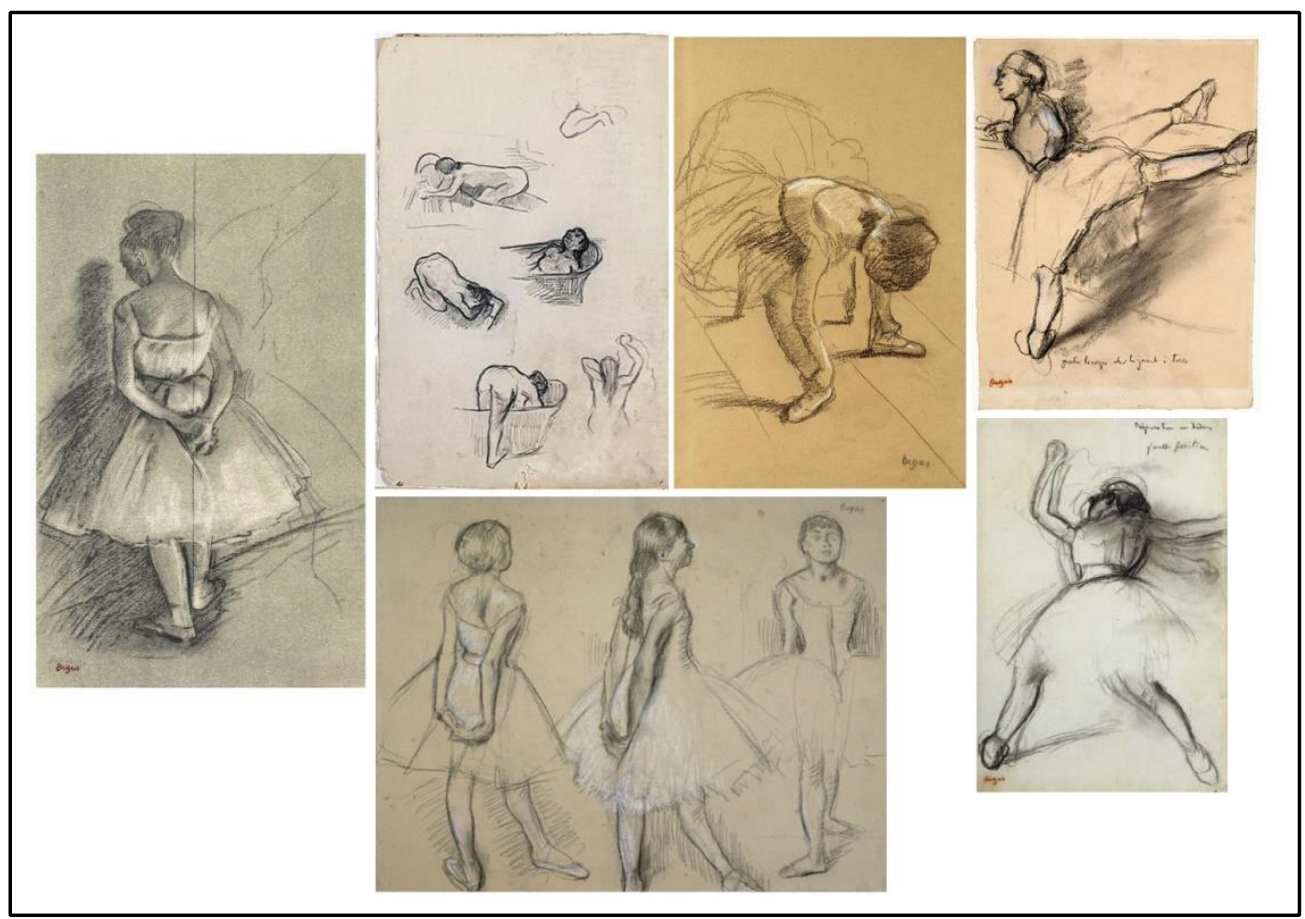

Fonte: http://imgarcade.com/1/edgar-degas-gesture-drawings 
Figura 60 - Esboço de Edgar Degas, 1879 em comparação com um detalhe do manga de Hokusai

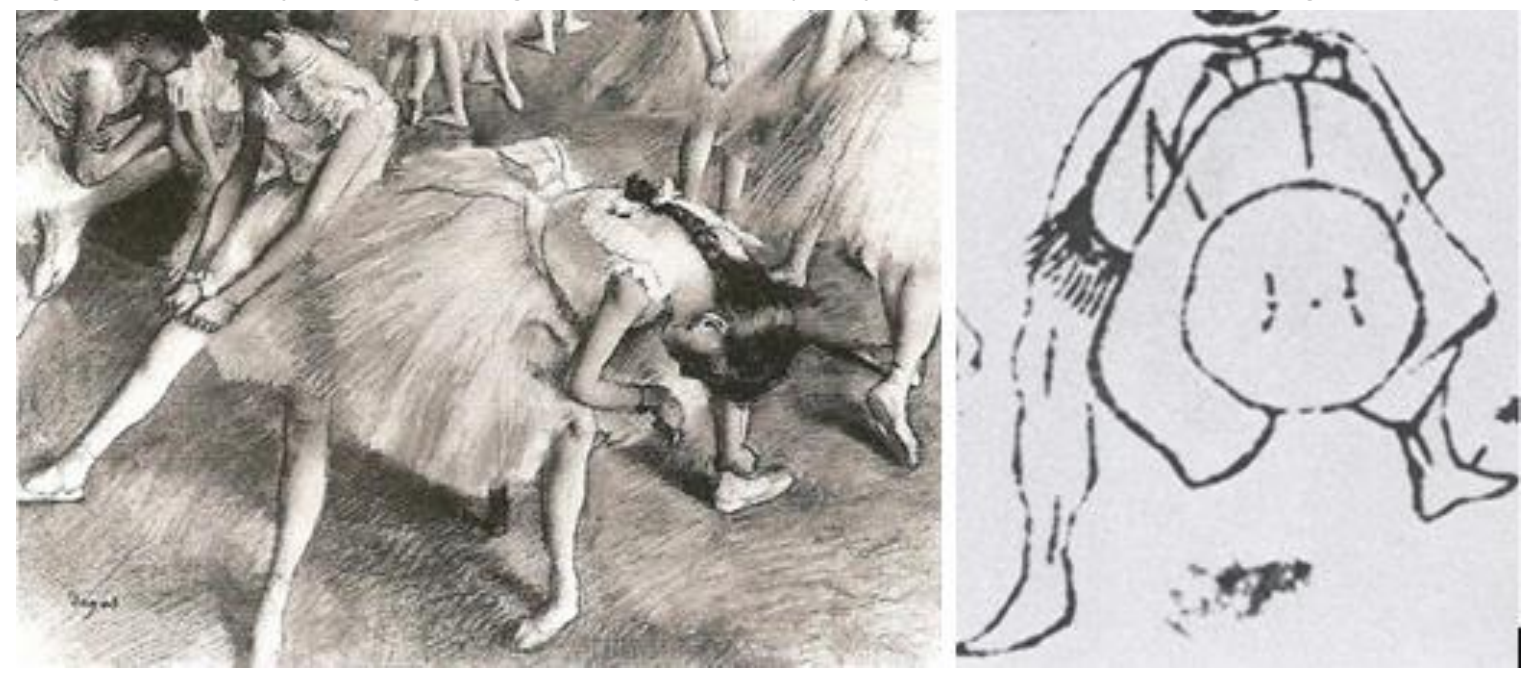

Fonte: http://www.wikiart.org/en/edgar-degas

A influência estética japonesa entre os pintores europeus foi extremamente fecunda; seu resultado espelhou a nova maneira de interpretar o mundo, malgrado as diferenças individuais. Direta ou indiretamente, a gravura ukiyo-e e a arte japonesa em geral forneceram combustível suficiente para influenciar não só o que pintariam, mas como pintariam. Essa revolução iniciada pelos impressionistas que, enfim, triunfam, expande-se também em outros desdobramentos estéticos que surgiram posteriormente ou em simultâneo.

\subsubsection{Os efeitos estéticos}

Desde o aparecimento da policromia, em meados de 1760, o ukiyo-e sustentou, ao longo de seu desenvolvimento, as cores intensas e brilhantes características. Segundo Bell (2002), tais matizes relacionavam-se com as complexas interações de preferência pessoal do artista, mudanças na moda, regulamentação governamental, inovações técnicas em pigmentos e também com os significados com que cada cor trazia consigo. Cumpre observar, todavia, que não é o objetivo desse trabalho emergir na simbologia cromática.

É inevitável que esse rico recurso de policromia, quando chega ao Ocidente, forneça um novo estímulo visual aos artistas e, consequentemente, auxilie na definição de suas próprias paletas cromáticas. É nesse contexto que Vincent van Gogh, ao chegar à França em fevereiro de 1886, rejeita a cartela escura de seus primeiros trabalhos para abraçar as cores 
brilhantes e vivas das quais se tornou conhecido (Figura 27 e Figura 61). De acordo com Leavens (2009), seu contato com os artistas modernistas, aliado ao seu encantamento com as xilogravuras japonesas, e com os estudos delas, fez com que rapidamente substituísse os marrons pelos amarelos, vermelhos e verdes, transição que pode ser percebida ao analisar a obra de 1885, Os Comedores de Batata, época em que o Japonismo ainda não tinha feito uma impressão em van Gogh.

Van Gogh, como foi possível perceber ao longo do seu trabalho, muito se ancorou na arte japonesa para definir seu próprio estilo; com efeito, mais que qualquer outro de seus contemporâneos, possuía consciência do papel do Japão na modernização da arte Europeia. Em uma carta endereçada à sua irmã Wilhelmina van Gogh (1862-1941), em 1888, ele escreveu: "Você será capaz de ter uma ideia da revolução na pintura quando você pensar, por exemplo, nas coloridas e brilhantes imagens japonesas que se veem em todos os lugares paisagens e figuras. Theo e eu temos centenas de gravuras japonesas em nossa posse" (LEAVENS, 2009, p. 32).

Em sua obra Quarto em Arles, de 1888 (Figura 61), van Gogh explica a seu irmão que ele, por meio do simbolismo das cores, busca expressar o repouso absoluto, a tranquilidade e a simplicidade de seu quarto. De acordo com o site do Musée d'Orsay (2006), essa combinação de cores que ele descreve como "o lilás pálido, o vermelho desbotado do piso, as cadeiras e a cama em cromo-amarelo, os travesseiros e o lençol em verde limão, o cobertor vermelhosangue, o suporte laranja, o lavatório azul, e a janela verde", articula-se com o Japão e com suas gravuras, assim como a composição, que é construída quase inteiramente de linhas retas. Ele teria dito, como registrado em Sullivan (1973, p. 233): “Aqui a cor é tudo... as sombras são suprimidas: é pintado em livres áreas chapadas assim como as gravuras japonesas". 
Figura 61 - Quarto em Artes. Vincent van Gogh, 1888

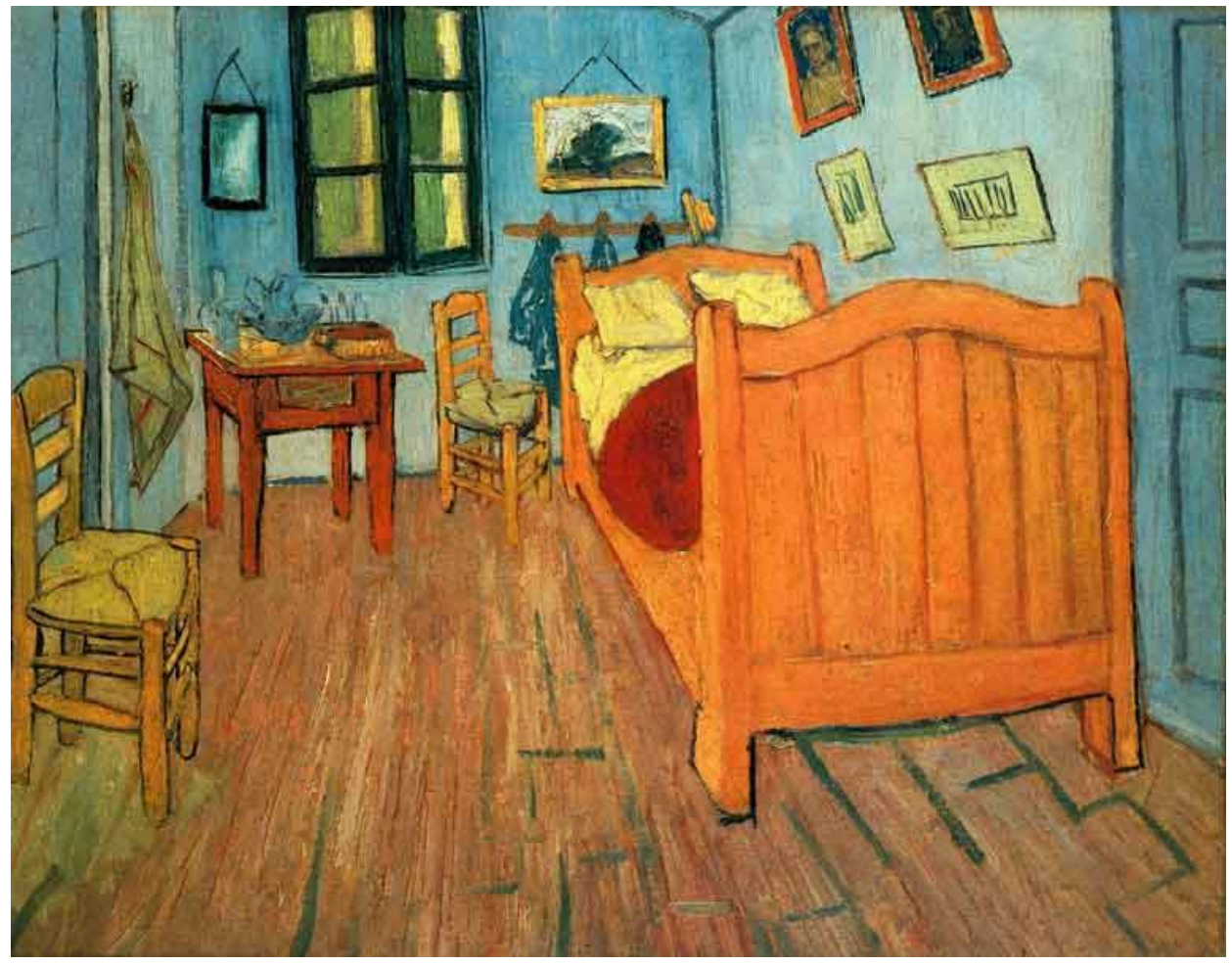

Fonte: http://www.musee-orsay.fr

Na opinião do já citado jornalista e crítico de arte Théodore Duret, a cor seria o principal presente do Japão para a arte francesa. "A chegada das imagens e álbuns japoneses completou a transformação, iniciando-nos a um sistema absolutamente novo de cores. Sem os métodos revelados pelos japoneses, toda uma série de meios pictóricos teria permanecido desconhecida entre nós" (TINTEROW; LOYRETTE, 1994, p. 245).

Breuer (1994) assegura que Mary Cassatt também possuiu suas cores determinadas pelas gravuras nipônicas, principalmente de Utamaro, artista pelo qual tinha grande admiração. Os azuis acinzentados, rosas, roxos e verdes, muitas vezes claros em tons pastel, à primeira vista, podem não se assemelhar às gravuras conhecidas justamente por suas cores fortes; porém, segundo Bell (2012), muitos pigmentos das gravuras japonesas são conhecidos por suas qualidades extremamente fugidias, inerentes aos compostos naturais, os quais têm seu "tempo de vida útil pretendido" antes dos vinte anos. Dessa forma, a mesma gravura de Kitagawa Utamaro vista em uma impressão desbotada, irá reter pouca semelhança com o seu estado original. Se a paleta desvanecida das gravuras japonesas for considerada e comparada às obras de Cassatt, a semelhança se torna clara. 
Outro componente que despertou o interesse dos artistas ocidentais foi o uso de múltiplos padrões em simultâneo. O Japão sempre possuiu uma enorme variedade de ornamentos, muito deles desenvolvidos em sua rica tradição têxtil. A estrutura de sua indumentária, que pouco se modificou através dos séculos, operou como uma área compositiva fecunda para a criação de padrões decorativos (WICHMANN, 2007).

A transposição desses ornamentos para a superfície pictórica, retratados de maneira igualmente deslumbrante, produziu impressionantes e memoráveis documentos para os artistas europeus. Apoiados pelo brilho incandescente de cores, esses padrões possuíam configurações tão exuberantes a ponto de se igualarem ou, até mesmo, de superarem a figura principal a ser retratada (Figura 62).

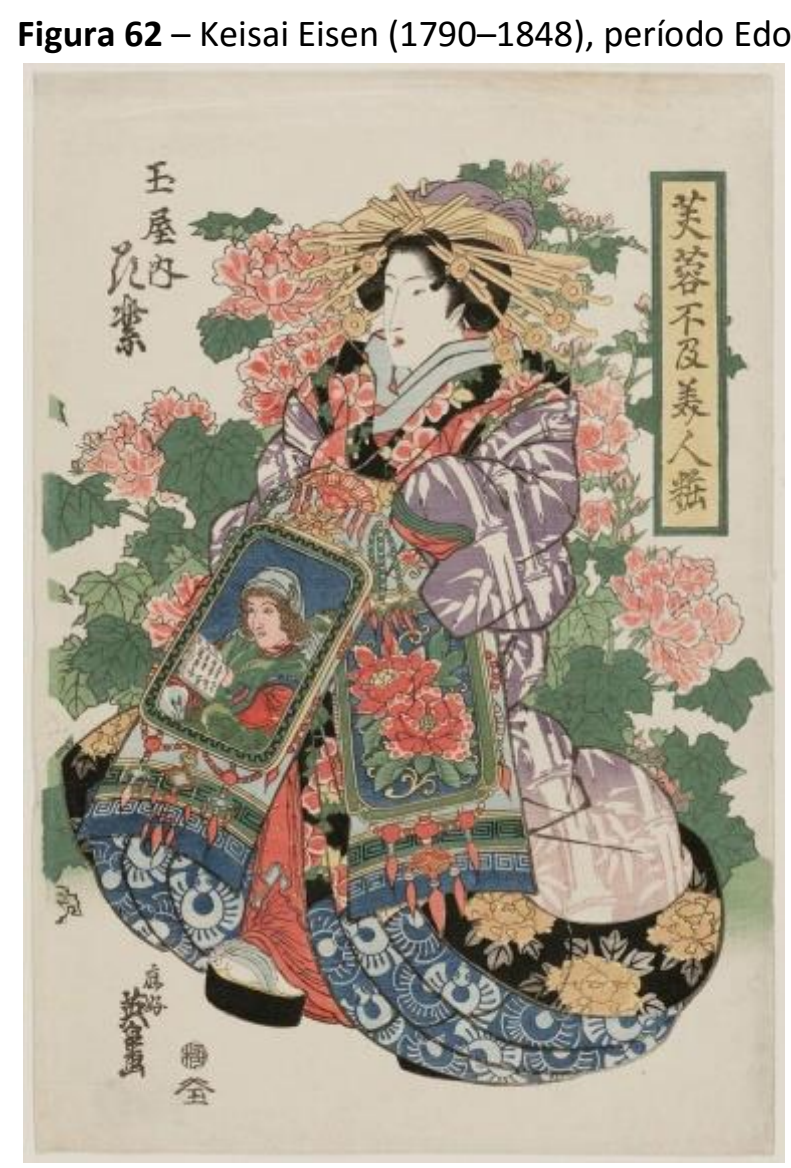

Fonte: http://ukiyo-e.org

Os artistas europeus reconheceram imediatamente o potencial abstrato, o vigor ornamental e as novas propostas de composições cromáticas, refletindo também na moda da 
época. O crítico Julius Lessing, citado por Wichmann (2007, p. 205), disserta sobre os têxteis orientais na Exposição Internacional de Paris de 1878, conforme mostra a Figura 63:

Listras e pequenos quadriculados entraram na tecelagem europeia sob a influência da Ásia, através de técnicas puras e simples e, são tão intimamente ligados à tecelagem que, pelo menos de vez em quando, a moda volta-se para os padrões de listras e quadrados. [...] Os padrões decorativos da China e do Japão, entraram no repertório desenho de tecelagem europeu e são usados como modelos para novos designs.

Figura 63 - Furyu Nana Komachi. Kitagawa Utamaro, Período Edo

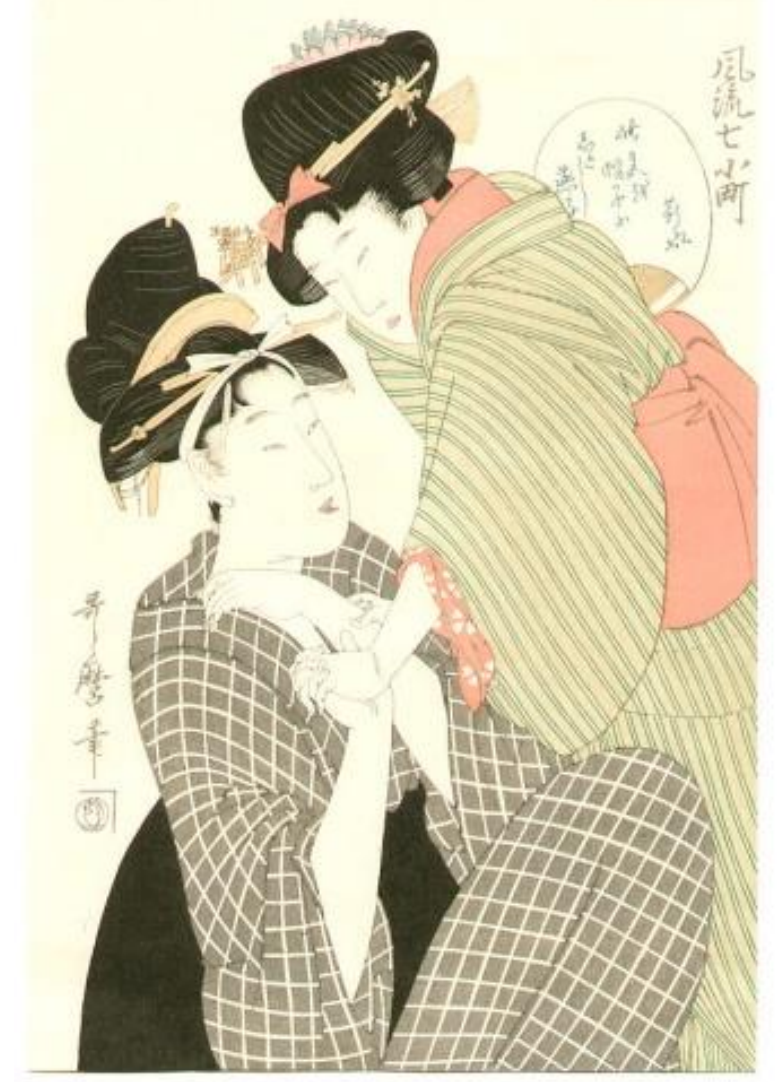

Fonte http://ukiyo-e.org/image/artelino/12344g1 
Figura 64 - La Mousmé. Vincent van Gogh, 1888

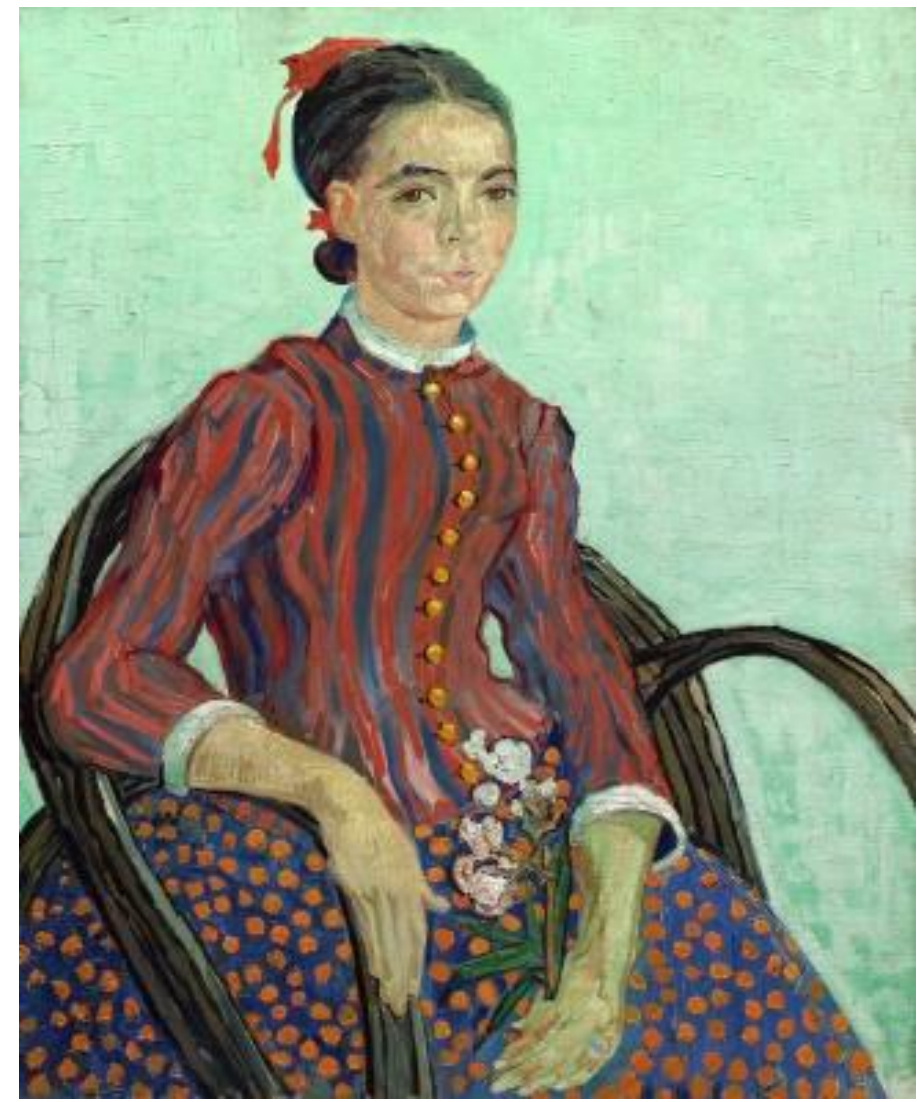

Fonte: http://www.vangoghgallery.com

Figura 65 - Mulher se banhando. Mary Cassatt, c. 1890

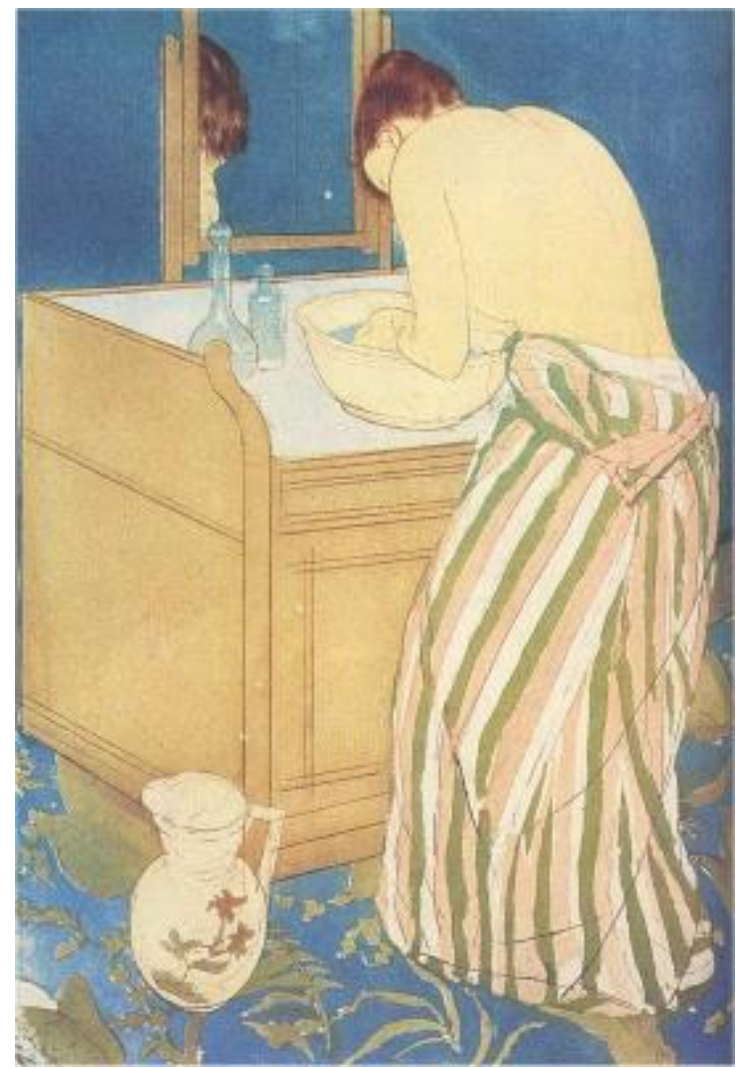

Fonte: http://www.metmuseum.org/toah/works-of-art/16.2.2 
A obra de Vincent van Gogh (Figura 64) e a obra de Mary Cassatt (Figura 65) configuram-se como uma pequena amostra dessa influência que foi traduzida de diversas maneiras, incluindo no grupo de artistas formado na última década do século XIX denominado Nabis. Pierre Bonnard (1864-1947), que se tornou um dos mais destacados artistas do grupo, escreve ao seu amigo Gaston Diehl (1919-1999) referindo-se às estampas ukiyo-e:

Em uma loja de departamento, por algumas moedas de um centavo, eu encontrei papéis impressos de crepe ou papel de arroz em cores deslumbrantes. Eu cobri as paredes do meu quarto com estas brilhantes, ingênuas imagens... Essas figuras que estavam na minha frente eram extremamente hábeis e animadas (IVES; GIANBRUNI; NEWMAN, 1990, p. 14).

Bonnard, que vem a ser conhecido posteriormente como o "Nabis Japonard", ao ser questionado sobre a maior contribuição da arte japonesa em suas obras, responde sem pestanejar, "o padrão quadriculado" (COLLEGE; GLIEM, 2008). Essa estampa, que pode ser conferida em inúmeras de suas obras, como A Toalha Vermelha, de 1910, na gravura Cena familiar (Figura 67), Mulher com Cachorro (Figura 66) é utilizada também em conjunto com outros padrões, nos painéis Mulheres no Jardim (Figura 68), que possuem cores brilhantes e formatos verticalizados extraídos da arte japonesa. 
Figura 66 - Mulher com Cachorro. Pierre Bonnard, 1891

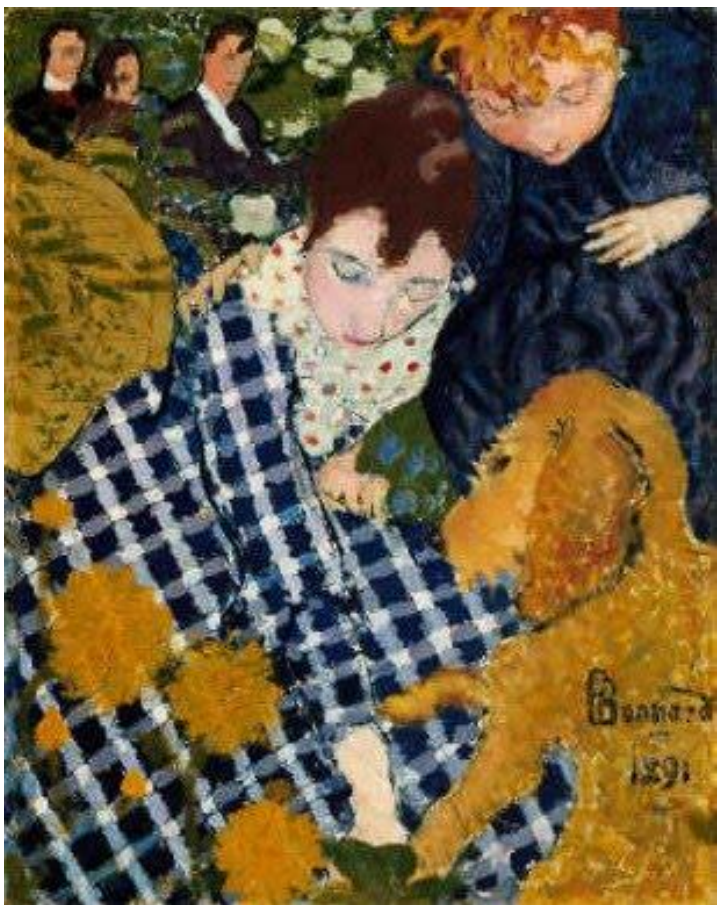

Fonte: www.metmuseum.org

Figura 67 - Cena familiar. Pierre Bonnard, 1893

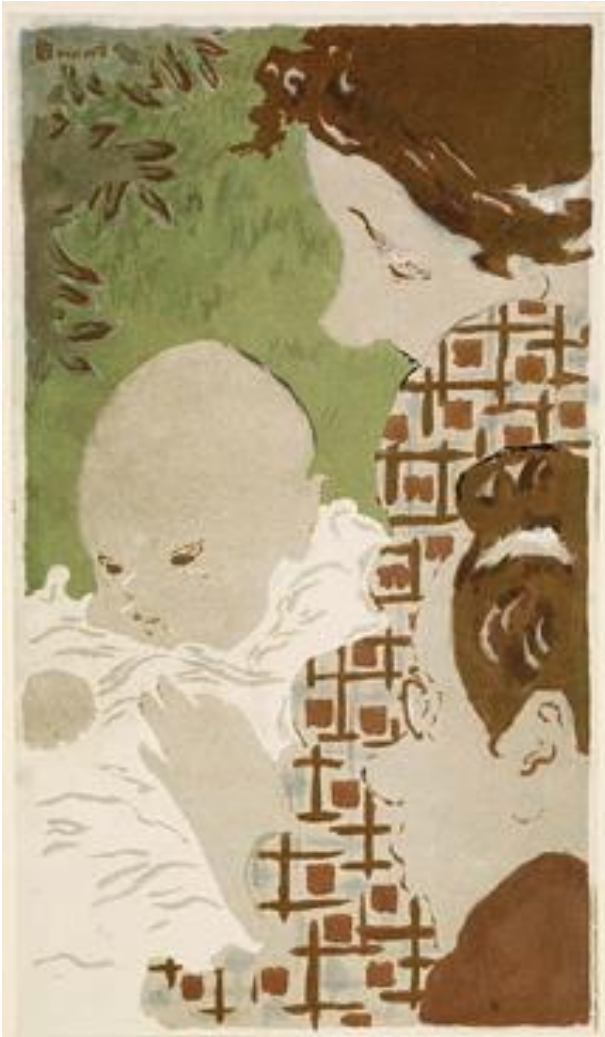

Fonte: www.metmuseum.org 
Figura 68 - Mulher no Jardim. Pierre Bonnard, entre 1892 e 1899

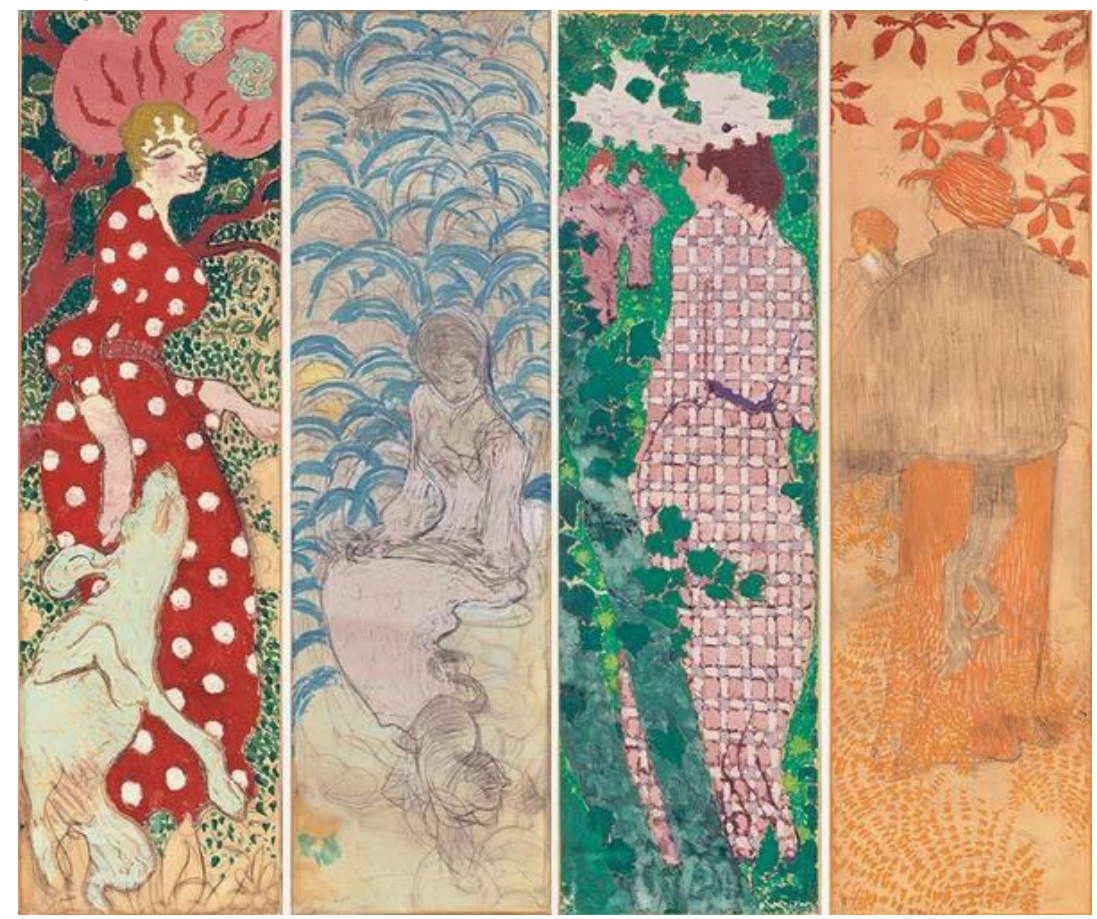

Fonte: http://www.escapeintolife.com/essays

Wichmann (2007) ainda afirma que Édouard Vuillard (1868-1940), outro artista do grupo dos Nabis, compartilhou com Bonnard a mesma abordagem pictórica sobre a técnica dos múltiplos padrões. Além disso, mais do que simplesmente inserir adornos em suas obras, também arranjam o espaço de forma que as diversas áreas pictóricas densamente ornamentadas sejam, por fim, integradas e unificadas.

A bidimensionalidade, já presente anteriormente, configurou-se como um elemento essencial entre os Nabis, que tratam os objetos e figuras - e, na verdade, tudo - como parte de uma única textura ornamentada, colocando toda a composição em um mesmo plano.

Vuillard e Bonnard diferem-se da primeira geração de impressionistas franceses. Com efeito, eles não buscaram transmitir as qualidades tonais da luz do dia, mas possuíam como conceito a arte como decoração, no qual o princípio de múltiplos padrões, aliado à bidimensionalidade, eram os principais pontos de interesse. Essa completa congruência entre as formas da superfície, segundo Wichmann (2007), é, talvez, o mais importante desenvolvimento na arte da virada do século, pois essa técnica, a longo prazo, se direciona rumo ao abstracionismo, no qual a figura permanecerá sempre um fragmento de um todo (Figura 69 e Figura 70). 
Vuillard que, semelhante aos mestres do ukiyo-e, era associado à indústria têxtil, segundo Wye (2004); constrói a obra Vallotton e Misia através do empilhamento dos elementos, de modo a não permitir qualquer sugestão de profundidade no sentido de perspectiva central.

Figura 69 - Misia and Vallotton at Villeneuve. Édouard Vuillard, 1899

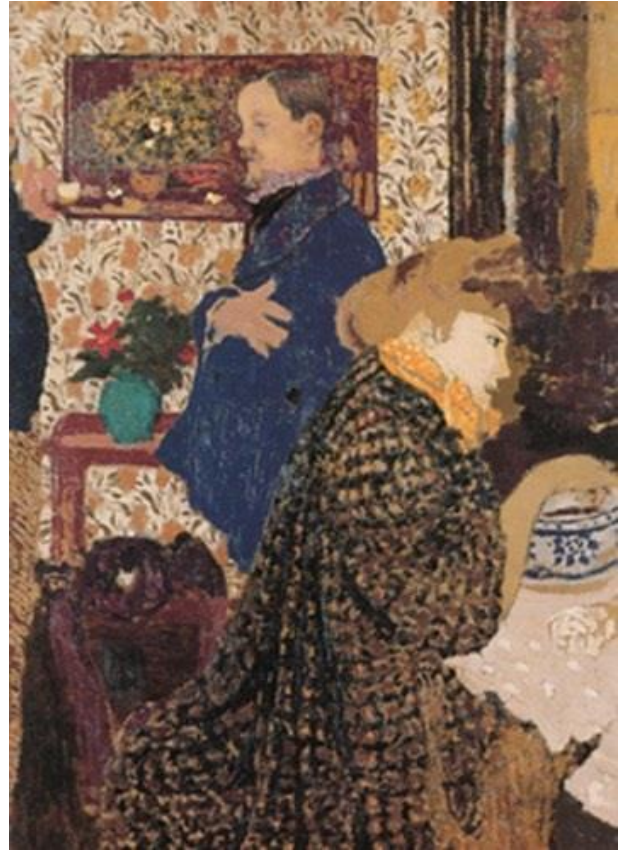

Fonte: http://www.artsjournal.com

Figura 70 - Mulher Cerzindo. Édouard Vuillard, c. 1891

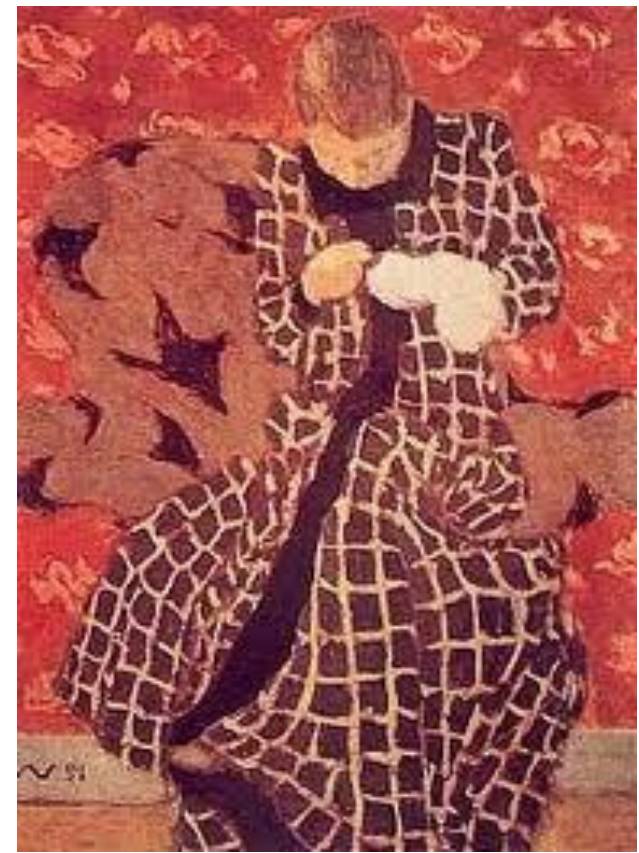

Fonte: http://www.britannica.com 
De igual modo, os Nabis expressaram em simultâneo a linguagem pictórica do Fauvismo, a corrente artística do início do século $X X$, que, mesmo possuindo duração de apenas alguns anos, também se relacionavam com a arte oriental, uma vez que ambos projetaram a planificação, as cores brilhantes e as pinceladas espontâneas em suas composições (Figura 71).

André Derain (1880-1954), um dos expoentes do Fauvismo teria dito: “Os japoneses veem as coisas desse modo. Eles não pintam a luz do sol, eles não desenham sombras, que causam perplexidade e falsificam a verdadeira forma das coisas" (DEUTCH; FLAM, 2003, p. 39).

Figura 71 - Caminho de Mudança, L’Estaque. André Derain, 1906

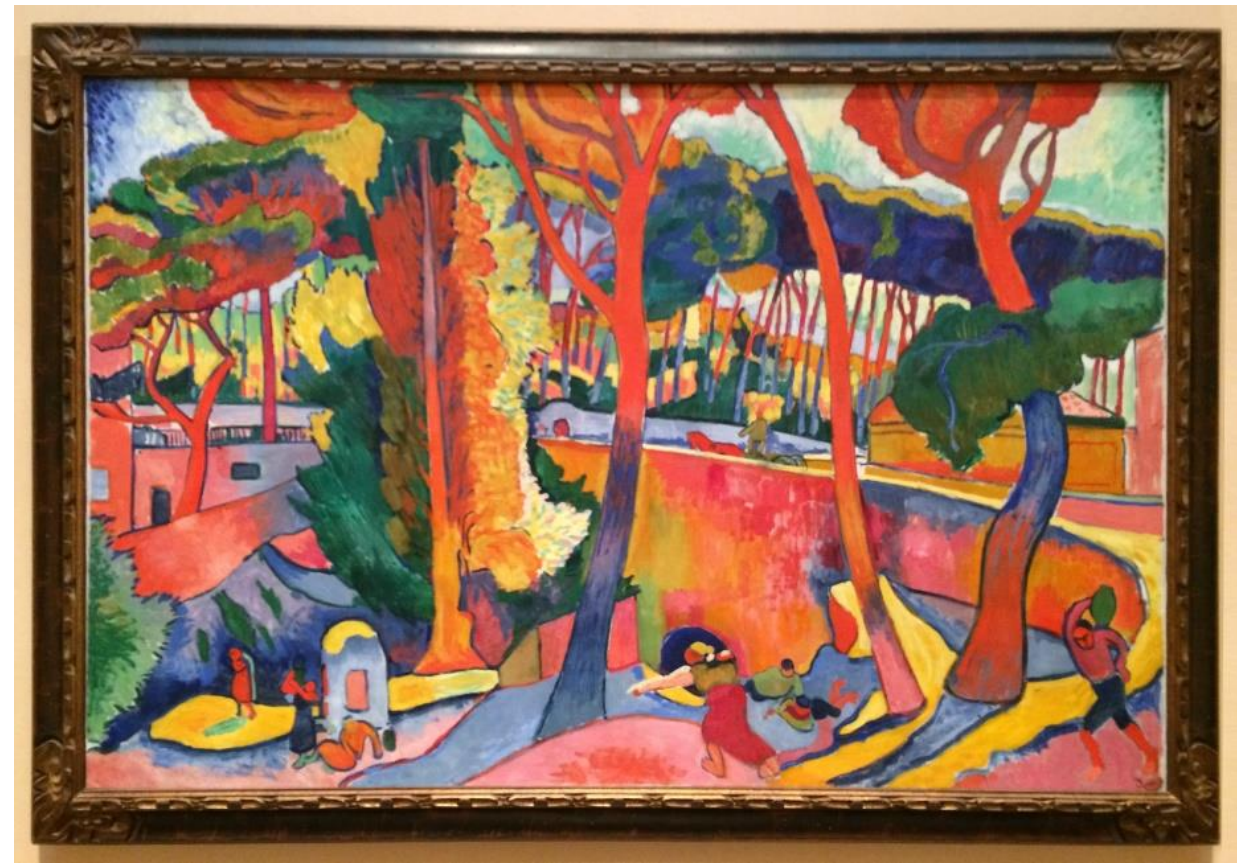

Fonte: Acervo de Luciana Iwamoto

Wieninger (2012) afirma que os artistas da Secessão Vienense, que desejavam o rompimento com as normas conservadoras, também sucumbiram à influência japonesa, de forma que, em 1907, Gustav Klimt (1862-1918), o líder do movimento, cria uma de seus mais notáveis retratos: Adele Bloch-Bauer (Figura 72). Sabe-se que ele possuía uma impressionante coleção de quimonos e de vestuário de teatro, eque ainda se beneficiou da publicação trilíngue de Samuel Bing, Le Japon Artistique, a qual, segundo Lambourne (2005), foi por ele adquirida como coleção completa em 1906. 
A figura, além de estar deslocada do centro e estar ausente de sombras, é retratada em suntuosas vestes, construída de forma que seu corpo se dissolve em ornamentos. Wichmann (2007, p. 208) afirma que "a combinação de grandes e pequenos padrões decorativos, e os retalhos de ouro e prata, que se destacam quase tridimensionalmente, são reminiscentes das características da xilogravura japonesa".

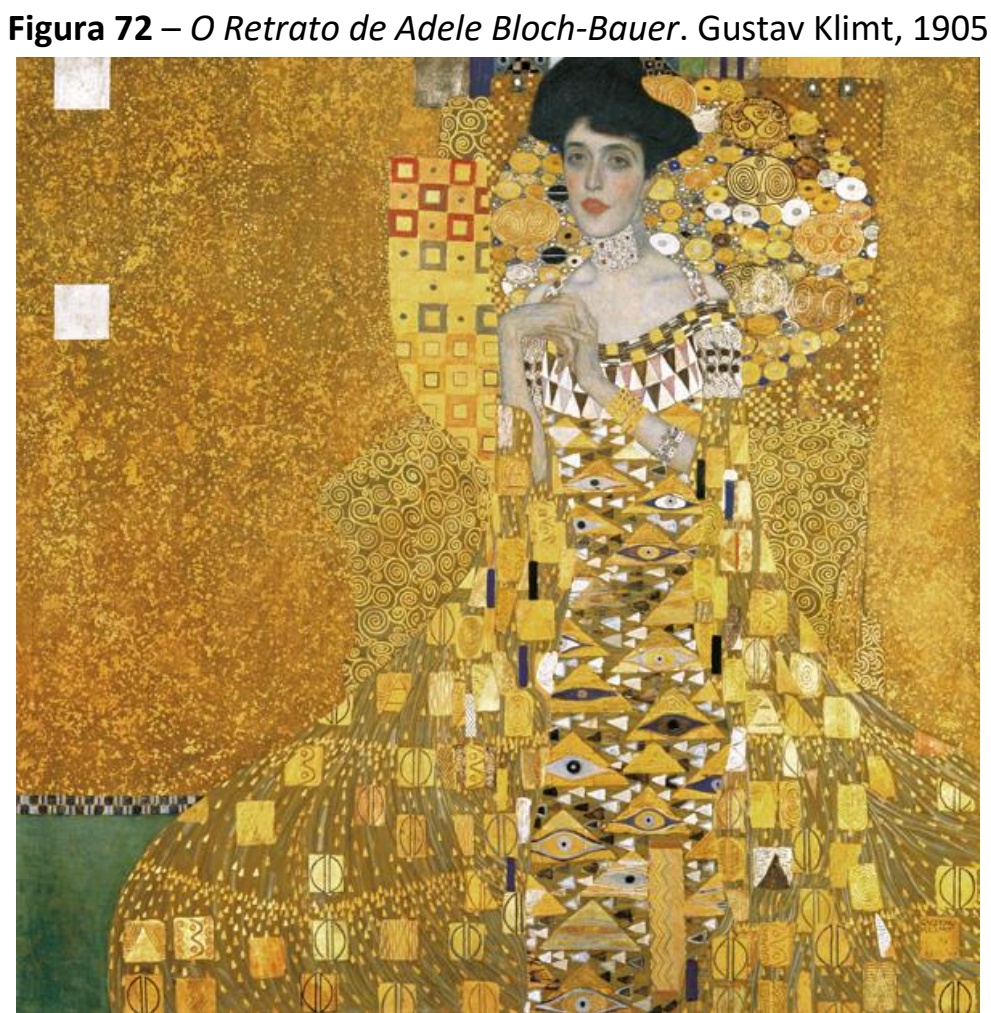

Fonte: http://www.moma.org

É também nesse contexto que outra ramificação se destaca no âmbito da arte. O cloisonné, recurso altamente técnico e resguardado no campo das artes decorativas, se traduz como elemento compositivo e passa a ser inserido nas produções bidimensionais ocidentais, pioneiramente por Louis Anquetin (1861-1932) na ocasião em que se apropria de um elemento da tão apreciada gravura japonesa que não tinha sido integrado pelos impressionistas: os contornos pretos em evidência (Figura 73).

Esse estilo, que da mesma maneira surgiu na Europa no final do século XIX, foi cunhado pelo crítico de arte Edouard Dujardin (1861-1949); seu domínio remete à antiga prática do esmalte cloisonné e dos vitrais. Nessa técnica, relata Pugliesi (2004), um filete separa as áreas para receber o material de esmaltação, as quais resultam em superfícies coloridas 
enclausuradas por contornos, característica essa também intrínseca ao ukiyo-e que define a organização e o esqueleto estrutural de suas composições pictóricas.

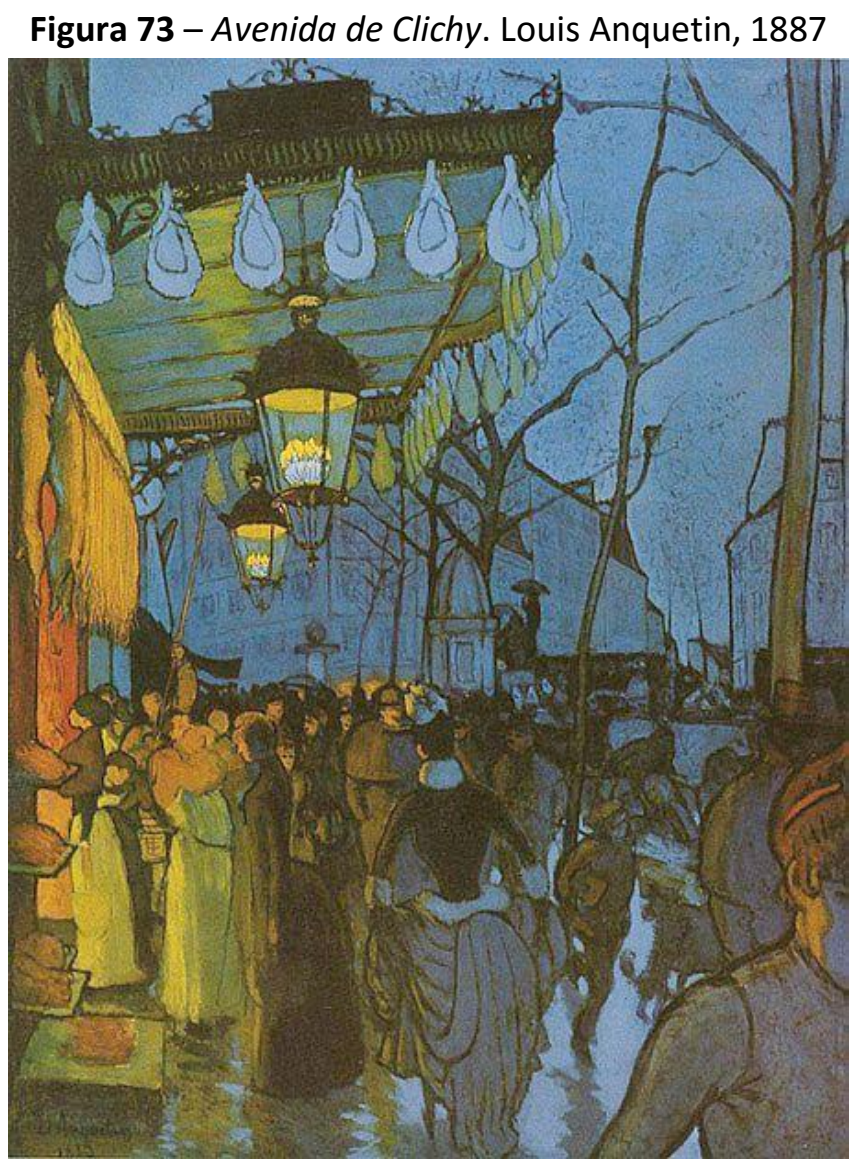

Fonte: http://www.wga.hu

Émile Bernard (1868-1941) foi quem traduziu o conceito de cloison para o estilo pictórico denominado cloisonnisme. De acordo com as descrições do Musée d'Orangerie, em Paris, o qual abrigou uma exposição temporária dedicada a Émile Bernard em 2014, ele declarou em 1886 que "O estudo das gravuras japonesas nos conduziu à simplicidade e, com isso, inventamos o cloisonismo" (Figura 74).

Segundo Pugliesi (2004, p. 5),

Não apenas ele usava o cloison, que nasce como tentativa de se afastar da representação naturalista da academia e até mesmo dos impressionistas, enclausurando as figuras com um contorno estilisante segundo a moda japonista, como também permite uma reestruturação do espaço de um modo que nem o impressionista Degas, nem o "mestre" Gauguin fizera, rompendo com o espaço tradicional renascentista. 
Figura 74 - Mulheres bretãs no prado. Émile Bernard, 1888

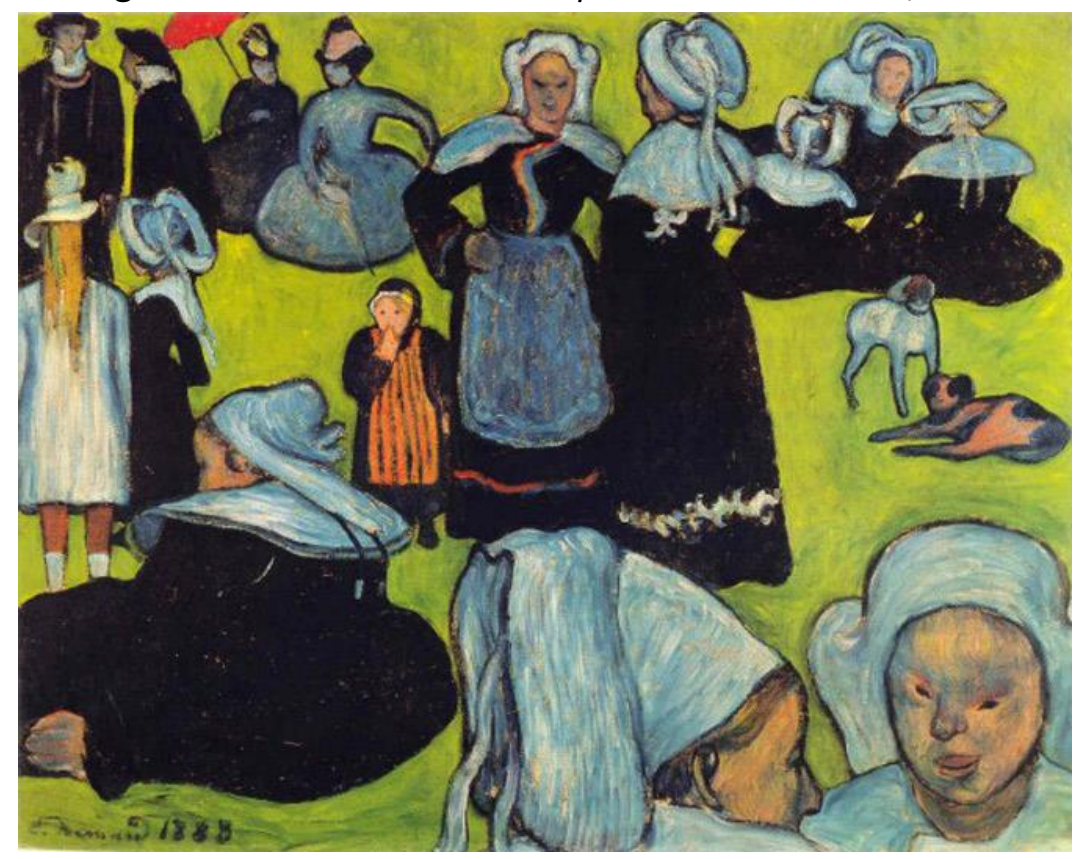

Fonte: http://www.britannica.com

Esse elemento também foi absorvido por vários outros artistas como Paul Gauguin, Meijer de Haan (1852-1895), Paul Sérusier (1864-1927) e Paul Ranson (1864-1909), mas não foi compreendido pela maioria dos críticos da época, mesmo que a arte japonesa fosse tão popular nesse período.

O cloisonnisme, que também ficou conhecido como sintetismo, possibilitou a estilização e abstração das figuras, da maneira como seria depois explorada por muitos movimentos artísticos. Champigneulle $(1972$, p. 83) constata que, tanto o Art Nouveau - que inclui, além das artes gráficas, a arquitetura e as artes aplicadas - os Nabis, os Fauves e os Cubistas "encontram-se na mesma fonte de inspiração: um grafismo tomado de empréstimo aos artistas japoneses". 


\section{O JAPONISMO NA MODA}

Pezzolo (2013), em seus estudos sobre a moda e a arte, afirma que o Japonismo constituiu o primeiro registro de participação formal de diferentes culturas no âmbito da arte. Em seu momento histórico, tal fato supriu as necessidades de introduzir, como referido em páginas anteriores, uma nova estética visual no Ocidente no instante em que os artistas vanguardistas buscavam uma nova visualidade. Essa coincidência histórica é o que difere o Japonismo das outras formas de Orientalismo, pois permitiu que houvesse a identificação do papel da arte japonesa na modernidade. Nesse contexto, muito do olhar antigo se modifica, propondo inovações que quebrariam definitivamente o academicismo.

Mesmo que um pouco mais tarde em relação à arte, a moda, que é também um aspecto de cultura visual que se configura como um reflexo de sua época abrangendo as esferas social, econômica e cultural, influenciada pelo cruzamento das duas culturas, incorporando, dessa forma, componentes oriundos do Japão. Tortora e Eubank (2005) enfatizam que os movimentos artísticos e a moda quase sempre se conectam e, que nesse caso, as conexões foram abundantes. Martin e Koda (1994, p. 11) reiteram:

As ideias orientais de têxteis, design e construção foram utilizadas repetidamente como um contributo positivo para a cultura do Ocidente. 0 Ocidente testou materiais e ideias orientais no vestuário e imediatamente as aprovou e as assimilou, muitas vezes de forma entusiasmada.

De acordo com Fukai (2007), é somente na década de 1880 que o Japonismo na moda alcança níveis mais evidentes, de modo que se mostrou necessário expor uma visão panorâmica dos padrões prevalecentes de moda da época.

O estilo Romântico, previamente abordado no subitem 3.2.1 no âmbito das artes, perdurou entre as décadas de 1820 e 1850 e expressou-se também na literatura e na música. Caracterizou-se pelo envolvimento dos sentimentos e das emoções, destacando a personalidade e os sentimentos interiores. Para os escritores e artistas românticos, esse movimento representou uma reação contra o estilo clássico formal dos séculos XVII e XVIII, nos quais os sentimentos interiores deveriam ser plenamente expostos. Na moda, traduziuse pelo estereótipo da mulher frágil e delicada. Tortora e Eubank (2005) afirmam que uma 
moça aparentar ter boa saúde era declaradamente fora de moda; daí porque olheiras eram cultivadas e o rouge substituído pelo pó de arroz, a fim de alcançar a pele alva, de aspecto doentio. O apertado espartilho, que tinha como propósito comprimir a cintura para se alcançar uma forma fisicamente perfeita e ideal, com frequência ocasionava diminuição da capacidade respiratória e inapetência (XIMENES, 2009), ajudando a alcançar o padrão de beleza enfermiço.

Figura 75 - Alteração do corpo provocado pelo espartilho

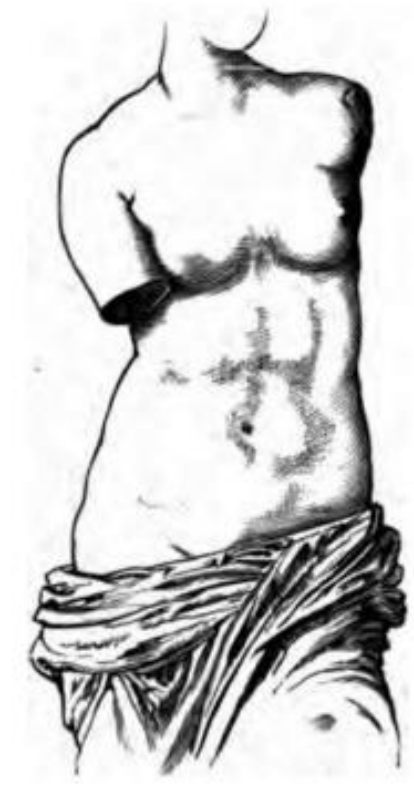

Fic. 2o.

Torso of the Statue of Venus of Mila.

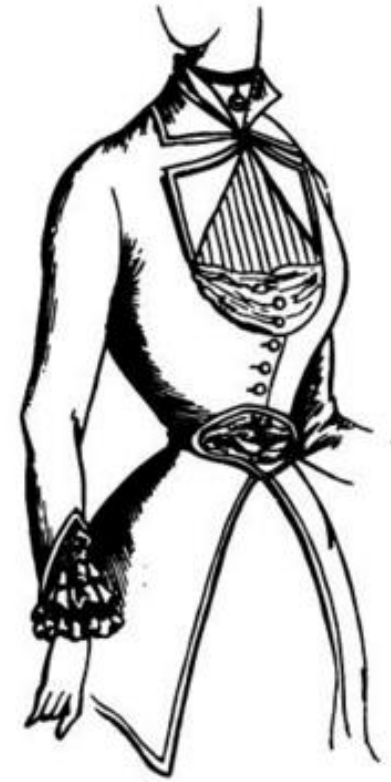

Fig. ax.

Paris Fashion, May 188 a

Fonte: FLOWER, 1881, p. 80

A sociedade industrial da época e o movimento crescente dos negócios fizeram com que a figura da mulher se restringisse ao confinamento do lar. As mulheres eram responsáveis pela imagem pública de sua família; as mais bem vestidas, aos olhos dessa sociedade eram as que portavam os mais complexos vestidos, cuja complexidade restringis seus movimentos e limitava uma série de atividades em que poderiam envolver-se. Desse modo, tornavam-nas virtualmente incapazes de realizar qualquer esforço físico (TORTORA; EUBANK, 2005). As revistas e periódicos de moda, relativamente recentes nessa época, eram as mais notórias fontes de informação e, com frequência, indicavam o horário e a ocasião adequados para cada 
tipo de roupa a ser vestida. Legendas como "vestidos para o dia", "vestidos de passeio", "vestidos para jantar", "vestidos de baile", eram comuns.

Após a referida Revolução de 1848-49, o romantismo perde sua força. A tecnologia do emergente processo fabril, as exposições internacionais e a cultura do divertimento urbano, temas já abordados neste trabalho, reestruturam os padrões de feminilidade. A perfeita dama resignada passa a ter uma personalidade mais exibicionista, que se refletia em elementos mais extravagantes no seu próprio vestuário (ISKIN, 2007).

O vestuário sofreu flutuações ao longo do período romântico, como no formato das mangas e do decote, comprimento das saias e posição da linha da cintura. Todavia, a silhueta básica permaneceu enfatizando a cintura fina.

Figura 76 - Nana. Édouard Manet, 1877

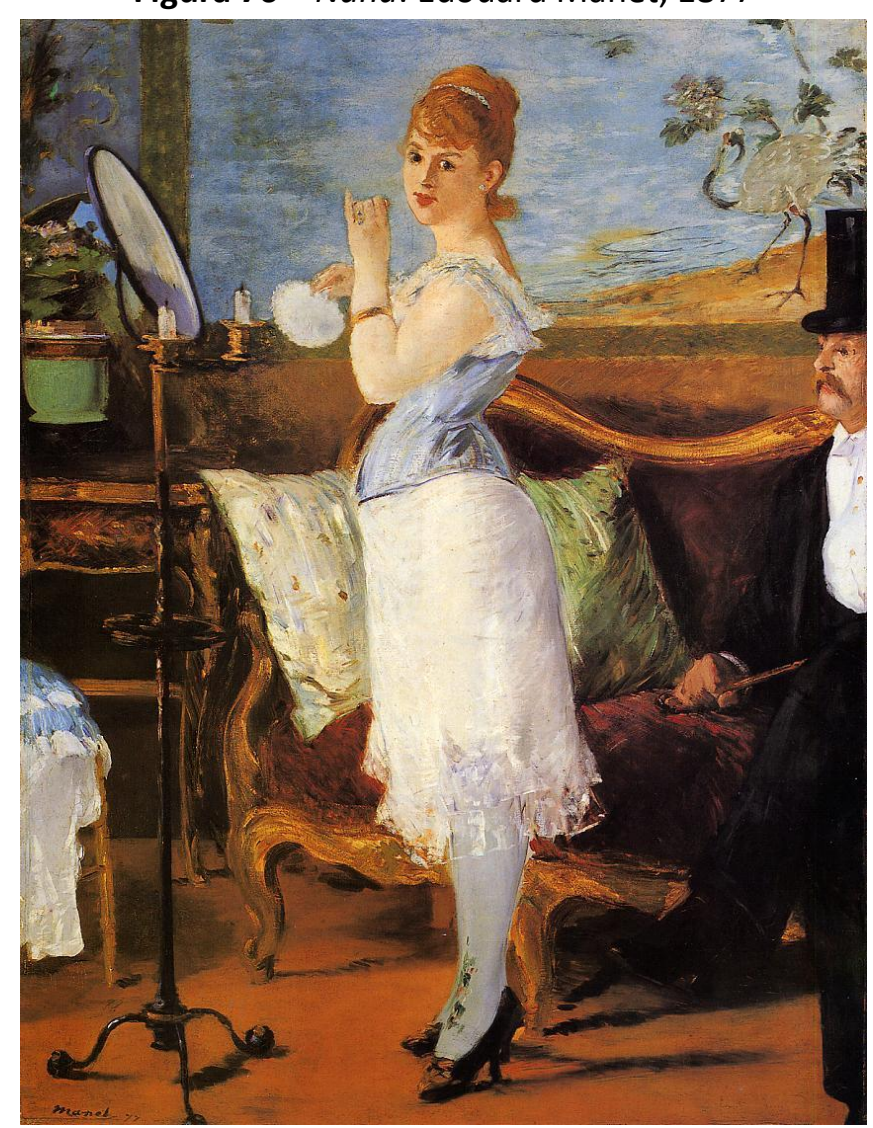

Fonte: http://www.wikiart.org

Segundo Martin e Koda (1994, n.p.), "raramente a moda confirma a forma da cintura natural”. E Fukai (1994) acrescenta que o espartilho se configurava como elemento essencial 
da moda feminina desde o Renascimento, século XIV, até a virada do século XX, salvo um breve período após a Revolução Francesa. Em conjunto com as novas tecnologias produtivas, o espartilho alcançou grande eficiência no seu objetivo de distorcer o corpo. Feixes de metal, assim como ossos de baleia eram inseridos, a fim de conferir ainda mais estrutura.

Nesse cenário, Martin e Koda (1994, n.p.) ainda registram:

\begin{abstract}
A moda pode suprimir alguns atrativos físicos e enfatizar outros. De fato, a história da moda demonstra um contínuo desejo de projetar um ideal de beleza alcançado através de modificações e alterações artificiais. Na medida em que os defensores da moda projetam qualquer ideal, o idealismo da cintura é central, mas a moda não pode ser considerada um incentivo às cirurgias, desnutrição ou autodestruição. Ao invés disso, as manipulações da cintura têm oferecido muitas ilusões e modificações para criar silhuetas com a aparência do corpo autoprojetado culturalmente desejado.
\end{abstract}

Segundo se constata em V\&A (2015), a cintura dividia seu foco com as contrastantes saias volumosas, estruturadas mediante inúmeras camadas de anáguas. E Ximenes (2009) completa dizendo que as estampas geralmente se faziam sobre o fundo branco para ampliar o efeito visual de volume.

Por evidente, porém, as múltiplas camadas, mostravam-se pesadas, quentes e antihigiênicas, principalmente no calor, de modo que em 1850 surge o suporte rígido, denominado crinolina. A crinolina mais popular era feita no início de crina de cavalo, do qual deriva seu nome, mas logo em seguida desenvolve-se e passa a ser construída com outros materiais, como a barbatana de baleia e o aço (a partir de 1857), produzindo novas e originais versões. Com essa inovação, as saias poderiam possuir volume com apenas uma camada de tecido; entretanto, não raro as crinolinas eram combinadas com outras camadas de tecido ou com anáguas quiltadas para uma máxima amplitude, que atingiu seu pico na década de 1860 (Figura 77) (V\&A, 2015). Os tecidos mais utilizados eram a organza e o tafetá, cujas texturas contribuíam para o efeito desejado, enquanto que a leveza do tecido de algodão, utilizado no início do século, não propiciava tal efeito e concentrava-se principalmente nas peças intimas e infantis (XIMENES, 2009). 
Figura 77 - Petit Courier des Dames, 1860

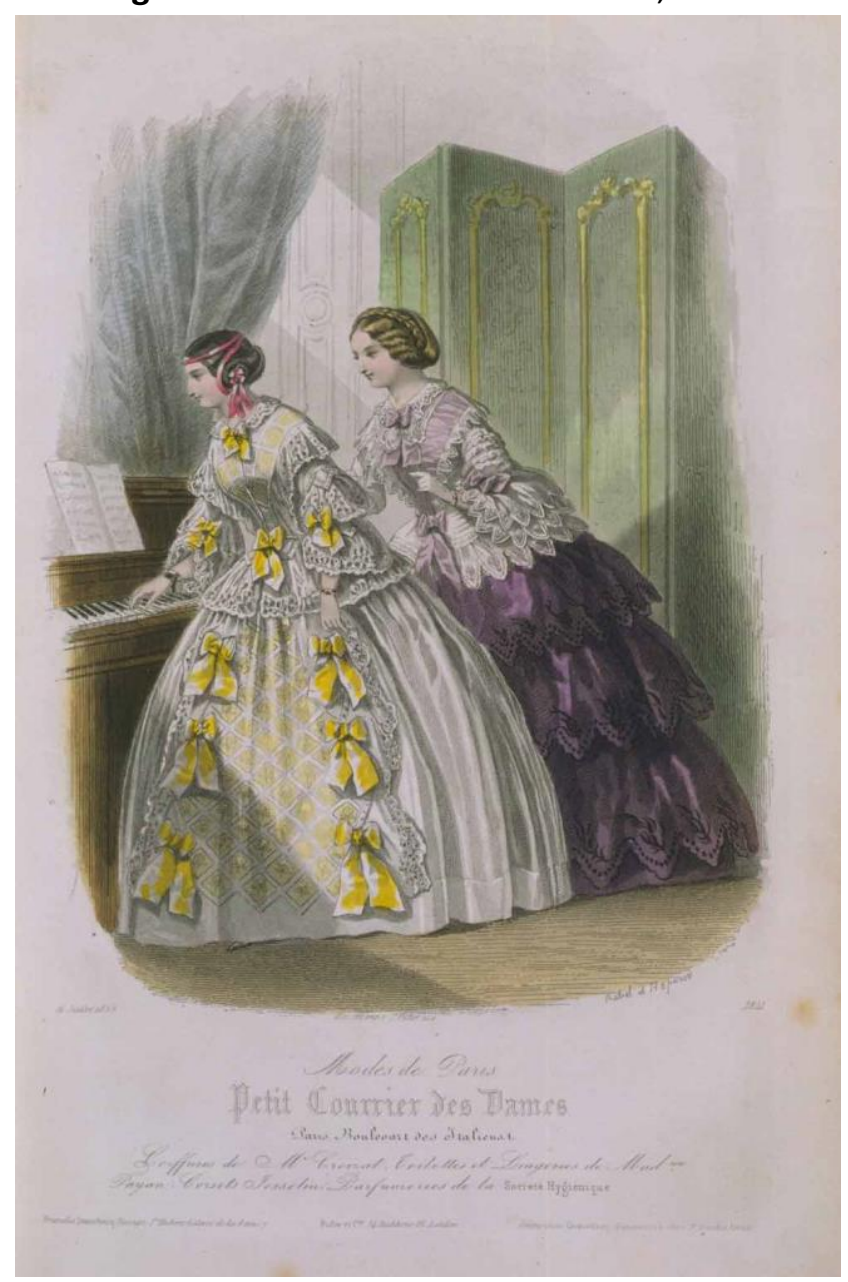

Fonte: http://www.vam.ac.uk

Figura 78 - Crinolina, 1860

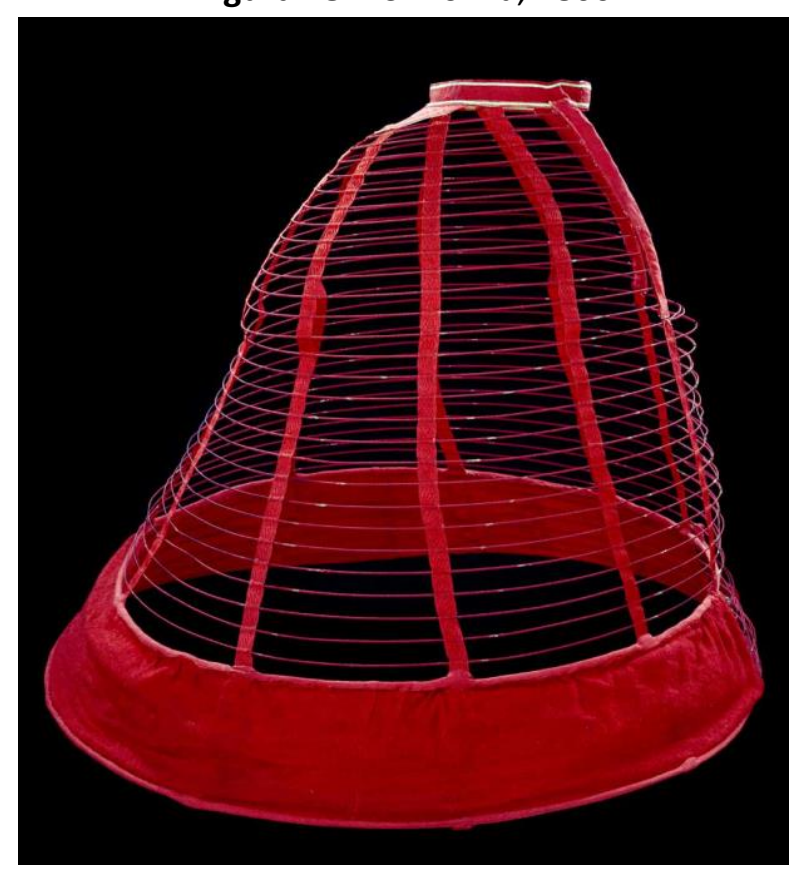

Fonte: http://www.vam.ac.uk 
O uso das crinolinas permitiu uma enorme expansão e volume nas saias, mas, no avançar das décadas, a saia em formato de domo cairia de moda. A crinolina deixa de ser utilizada em 1870, quando o volume passa a se projetar na parte de trás do vestido, apoiado internamente sobre a anquinha (Figura 79). O tecido que antes ficava sobre a crinolina seria deslocado cada vez mais para a parte traseira, até culminar na silhueta mais natural em forma de "S" do período denominado Belle Époque (1871-1914). Essa moda, que enfatizava as linhas sinuosas e motivos orgânicos decorativos, correspondia à corrente artística pan-europeia do Art Nouveau, que, como abordado no último item, também derivava do legado do Japonismo (von den DRIESCH, 2014).

Figura 79 - L'elégance Parisienne, 1874

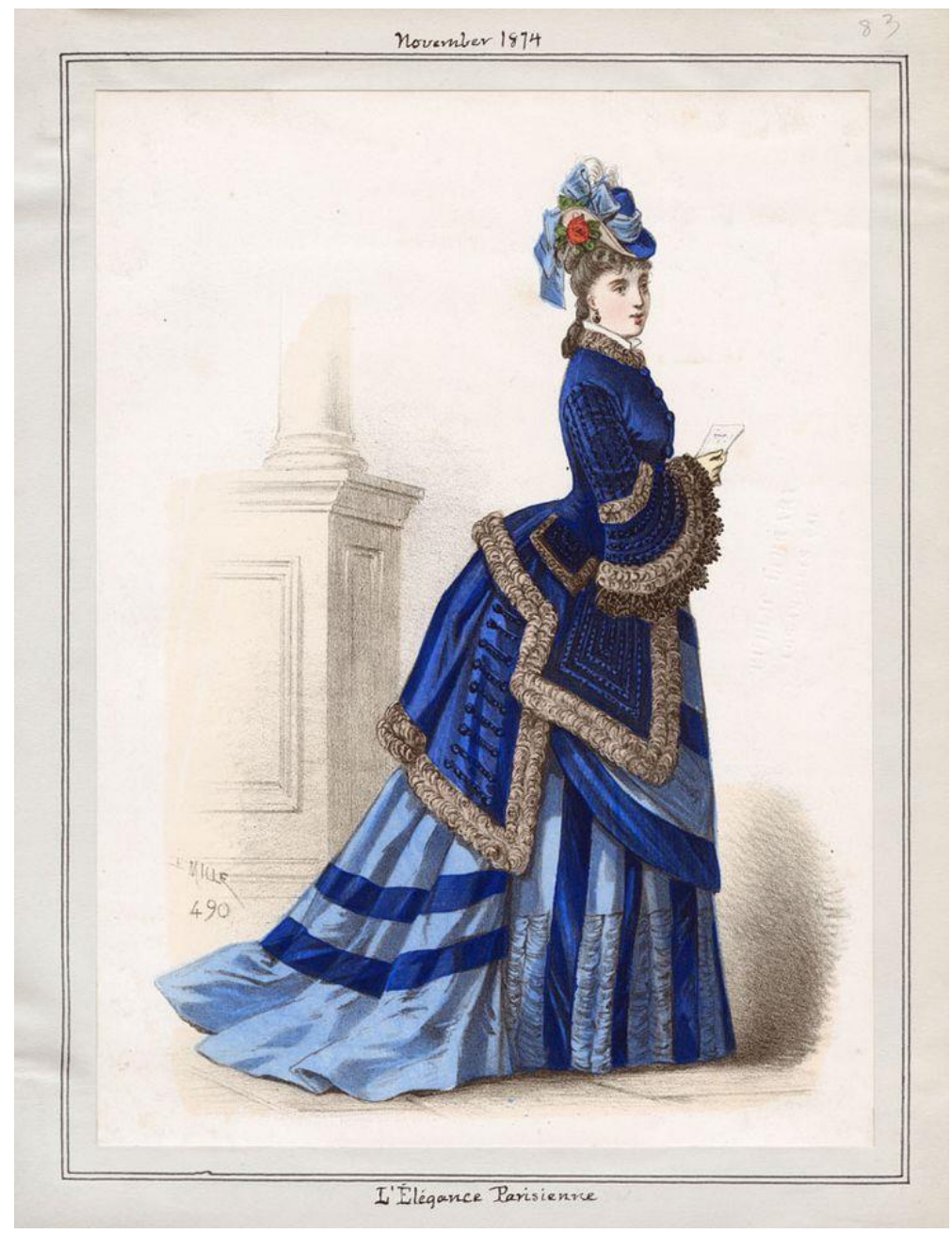

Fonte: http://paperthinpersonas.com

Foi com esse pano de fundo que o Japão começa a se fazer mais presente no cenário de moda europeu, por intermédio principalmente do quimono e dos têxteis que, entre os 
muitos objetos importados, estavam entre os mais proeminentes por, sobretudo, transcenderem a barreira de linguagem. Por mais que as gravuras ukiyo-e fossem a mais expressiva forma de arte que surgiu em termos de onipresença, o vestuário, apesar de ser atribuído como elemento periférico no campo da análise do Japonismo, estava mais intimamente ligado à tradição japonesa em relação às gravuras. Como defendem Geczy e Karaminas (2013b), o quimono configura-se como um identificador nacional e cultural até os dias atuais, sendo assimilado pelo Ocidente em inúmeros momentos.

Uma das mais notáveis e influentes teorias recentes sobre o assunto foi introduzida por Tonye Erekosima em 1979 e, posteriormente, em conjunto com Joanne B. Eicher em seus trabalhos sobre os têxteis de Kalabari. O conceito denominado "Autenticação Cultural" surgiu justamente devido à importância da transformação criativa na qual elementos estrangeiros acabam por fazer parte de uma já existente tradição e de um estilo já estabelecido.

Hamilton (1987, apud KIM; WILSON, 2002, p. 4) afirma que o vestuário se configura como um sistema subcultural, "único em sua particular manifestação cultural, mas universal em sua expressão". É devido a esse caráter universal de funcionalidade que a vestimenta possui o poder de ser rapidamente assimilada pelo público e mais propensa ao intercâmbio cultural, pois é suscetível a absorver novos conhecimentos e horizontes (MARTIN; KODA, 2011).

Martin e Koda (2011) ainda acrescentam que o estrangeirismo e o exotismo são mais aceitos nesse âmbito pois a tendência é pensar que o vestuário é menos fixo e menos projetado para uma longa duração. Associado ao encantamento, sedução e doçura, a presença oriental no vestuário é considerada inócua aos olhos ocidentais e, por isso, sempre foi muito bem-vinda. Siegfried Wichmann é testemunha:

não só a pintura, escultura e arquitetura oriental despertaram o entusiasmo
dos apreciadores e colecionadores, mas as artes aplicadas sentiram,
também, um impacto que ainda é percebido até hoje. No dia a dia, a moda
feminina foi fortemente influenciada pelo quimono japonês [...] e até mesmo
a moda parisiense transformada e em destaque entre 1860 e 1900 foi, por
assim dizer, importada do Japão (WICHMANN, 2007, p. 18).

No período de maior intensidade do Japonismo, alguns anos após a abertura dos portos no século XIX, bastou para a moda europeia absorver o aspecto de exotismo que o país 
longínquo representava. Em outras palavras, nesse primeiro momento, a moda contenta-se em assimilar apenas objetos importados e motivos figurativos representativos, como um empréstimo pontual da beleza do "outro", a fim de atender à demanda da população encantada pela sua beleza exótica. Lipovetsky (2007, p. 34) afirma: "não que a moda não conheça igualmente verdadeiras inovações, mas elas são muito mais raras do que a sucessão das pequenas modificações de detalhe".

\subsection{O ideal do quimono no Ocidente}

Com sua característica forma em " $\mathrm{T}$ ", o quimono significa literalmente "coisa para se vestir". Apesar de o fenômeno do Japonismo ter se iniciado na metade do século XIX, o quimono já teria feito sua rota rumo ao Ocidente muito tempo antes. De acordo com Fukai (1994), o Japão mantinha laços culturais e comerciais com o exterior desde 1639, principalmente com a vertente holandesa da Companhia das Índias Orientais, mas foi após a abertura dos portos e, principalmente, por meio das Exposições Universais que, de fato, o quimono conquistou um reconhecimento amplo. Segundo Kim e Wilson (2002), a casa de chá com mulheres de quimono foi uma atração muito popular na exposição de 1867 em Paris, e nesse ano, revistas como Journal des Mademoiselles já traziam ilustrações com a legenda "estilo japonês" (FUKAl, 1994).

O "estilo japonês" simbolizava de modo especial a novidade e o exotismo, da mesma maneira como o quimono fizera em muitas pinturas impressionistas, principalmente do início do fenômeno. Obras como Sacada (1870), A Princesa da Terra das Porcelanas (1864), La Parisienne Japonais (1872), de Alfred Stevens (Figura 82), e outras já aqui expostas como $A$ Japonesa ao Banho (1864) de Tissot, são concebidas a fim de representar um país exótico embalado em clima de mistério e, frequentemente, de sensualidade (MILHAUPT, 2014). 
Figura 80 - Quimono e Obi (faixa)
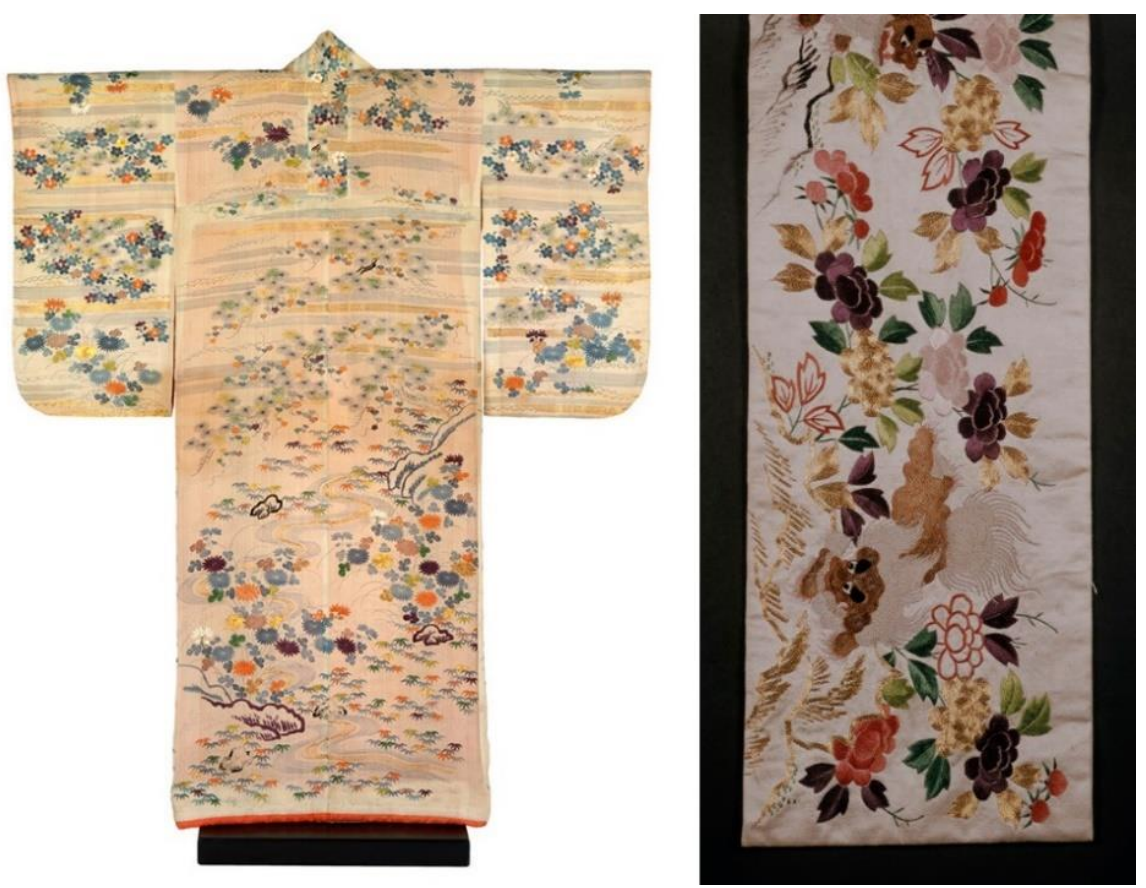

Fonte: http://www.vam.ac.uk

Figura 81 - A Sacada, 1867-1870 e A Princesa da Terra das Porcelanas, 1864. James McNeill Whistler

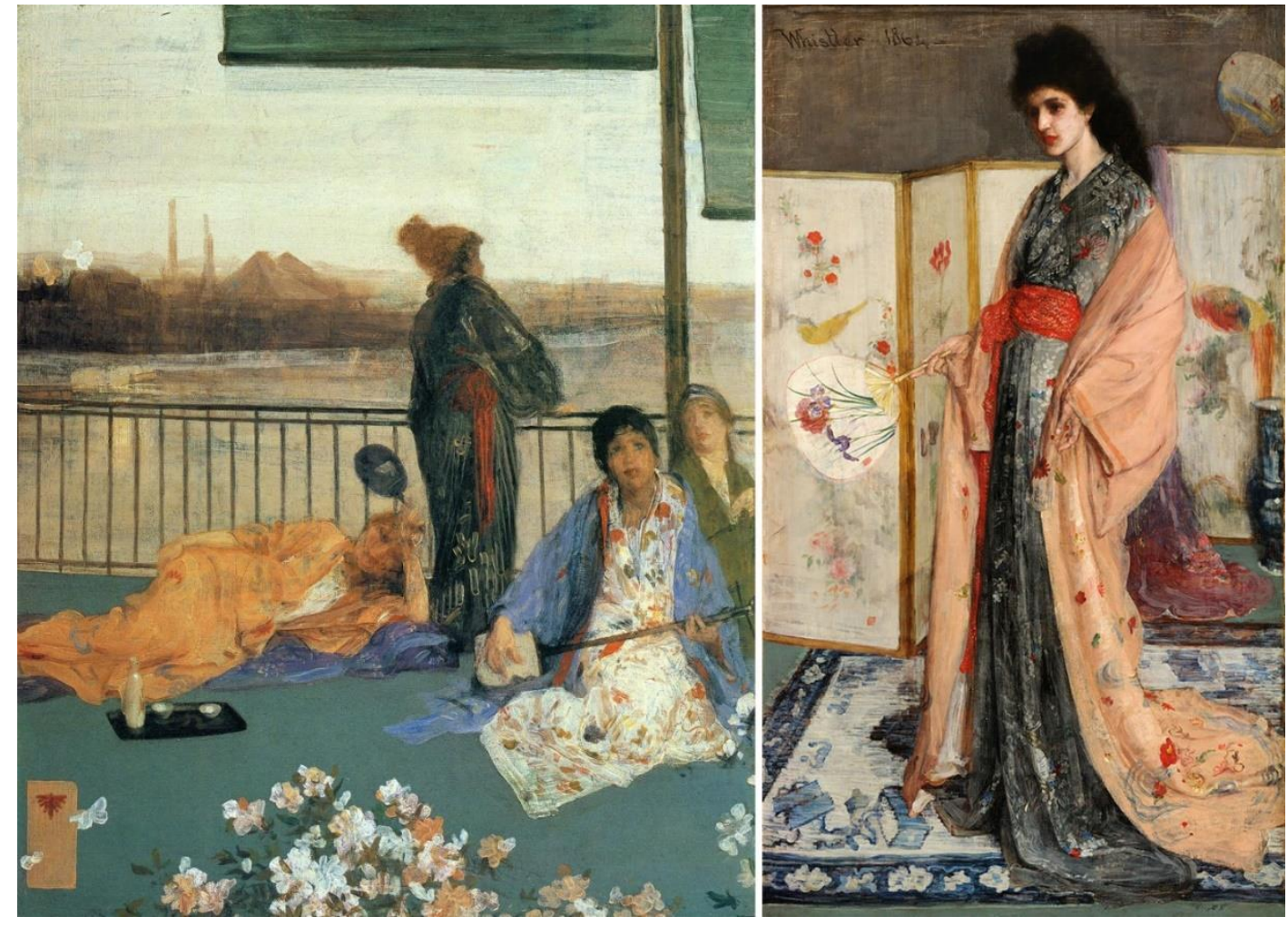

Fonte: http://www.jamesabbottmcneillwhistler.org 


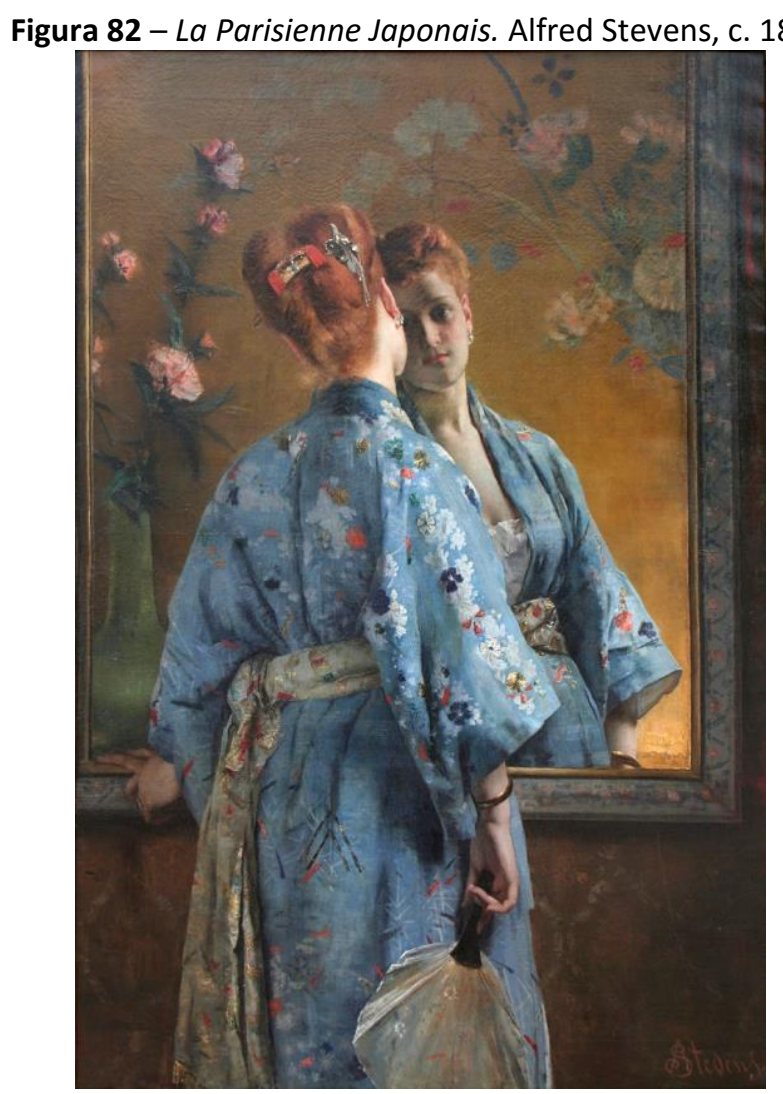

Fonte: http://www.metmuseum.org

Em 1882, Renoir finaliza o retrato Madame Hériot. As suas pinceladas soltas e imprecisas não impedem de visualizar claramente o quimono por cima do vestido vermelho, preso na cintura por um cinto combinando. Diferentemente das obras de Tissot ou de Whistler, o quimono nesse contexto é de modo claro, utilizado em um estilo ocidental, sem a pretensão de evocar mistério ou erotismo. Ainda segundo Fukai (2014), essa obra evidencia que, na época em que foi executada, o quimono configurava-se como tendência, sendo utilizado como um moderno traje para se usar em casa.

A França era reconhecida mundialmente como líder da moda e, na época, os impressos da Inglaterra e dos Estados Unidos demonstravam com clareza a influência do estilo da Parisiense, a idealização da mulher e da feminilidade contemporâneas. Nesse momento, novos laços são criados entre a arte e a moda através da figura da Parisiense, retratada por pintores vanguardistas a fim de expressar a energia vital da vida moderna e urbana. Suas poses, trajes e acessórios tornaram-se ferramentas do propósito dos artistas impressionistas (SIMON, 1995). 
A percepção dessa peça como vestes de interior, porém, não foi iniciada pelos artistas e nem pela população geral; essa percepção se deveu aos jesuítas portugueses e por Mathew Perry (1794-1856), Comodoro da marinha dos Estados Unidos responsável pela abertura do Japão ao mundo. Eles descreveram o quimono como " uma espécie de veste para ser usada a noite" e "um tipo de roupão preso por uma faixa em volta da cintura" (MILHAUPT, 2014), demonstrando a autêntica impressão do vestuário japonês aos olhos ocidentais.

Figura 83 - Madame Hériot. Pierre Auguste Renoir, 1882

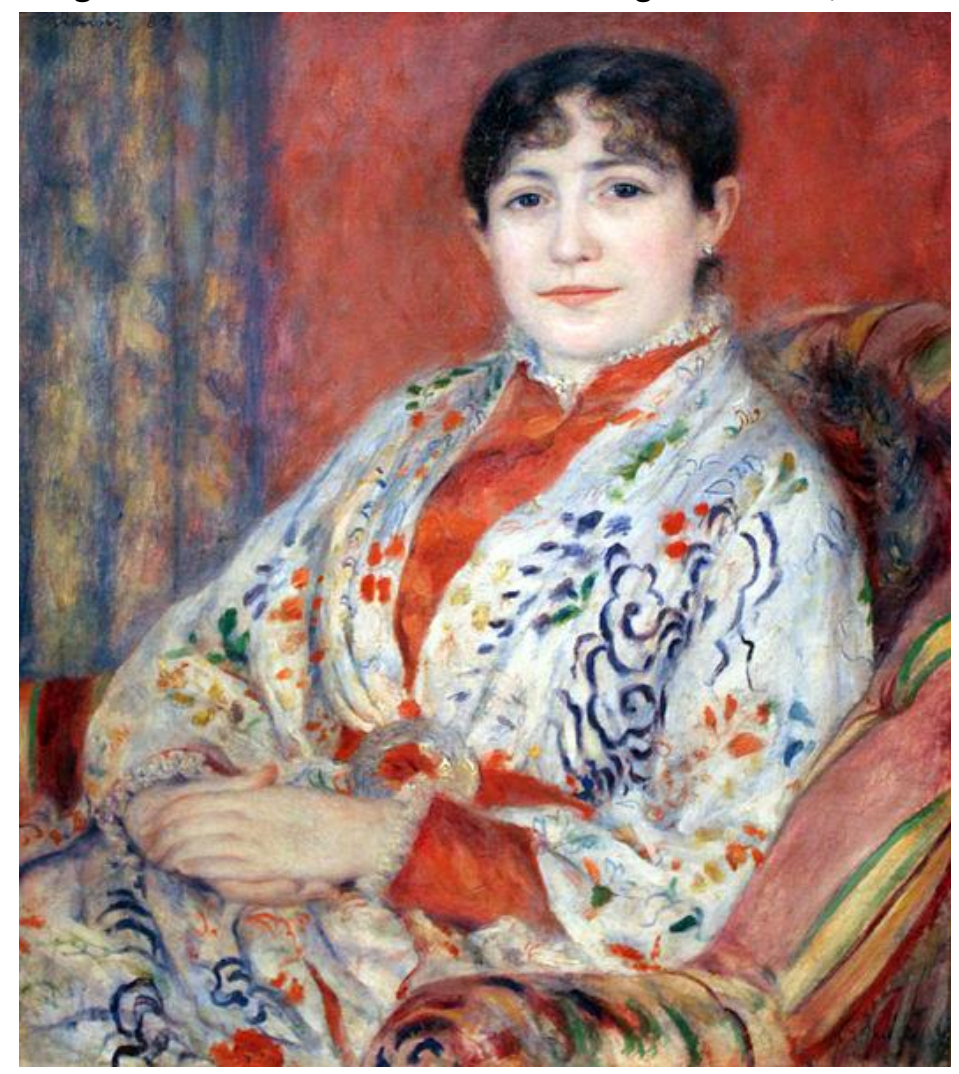

Fonte: https://commons.wikimedia.org

Segundo Fukai (1994), a ópera e o teatro foram as duas principais formas mais populares de entretenimento do fim do século XIX e início do XX. Esses dois gêneros alavancaram ainda mais a popularidade do quimono e de toda cultura japonesa em geral. Esses trajes brilharam pela primeira vez nos palcos parisienses em 1870, no teatro Goethe; antes disso, porém, óperas e peças teatrais sobre o Japão já existiam ubiquamente na Europa, sendo que o conhecimento das vestes japoneses já se faziam presentes.

O fator que merece destaque nessa ampliação foi o notável sucesso internacional da atriz japonesa Sada Yacco (1871-1946), regularmente conhecida como Sadayakko que, em 
1899, partiu com seu marido e uma pequena trupe de atores para realizar um tour pela América - o primeiro grupo profissional de atores japoneses a se apresentar ao Ocidente (DOWNER, 2013).

Desde São Francisco até Nova York e, posteriormente, Londres, Paris, Berlim e São Petersburgo, o público se emocionou com sua dança e ficou hipnotizado com sua atuação. Em sua trajetória, Yacco pôde apresentar-se para o presidente McKinley (1843-1901) em Washington, para o Príncipe de Gales, em Londres, para o imperador Francisco José (18301916) em Viena e; inclusive, jantou com o Tsar Nicolau II (1868-1918), o último imperador da Rússia. Pablo Picasso (1881-1973) produziu quatro retratos dela, deixando uma forte impressão em muitos outros no mundo da arte. Em Milão, Giacomo Puccini (1858-1924) assistiu todas as suas performances. Devido a isso, acabou profundamente influenciado pelos ritmos, música e pela atuação da atriz, levando-o a reformular sua famosa ópera Madame Butterfly, produzida até hoje (DOWNER, 2013). Fukai (1994), por sua vez, relata que, nesse percurso, Sada Yacco transformou-se de gueixa para a japonesa mais famosa de seu período, tornando-se sensação imediata ao chegar em Paris e se apresentar no palco do teatro Loie Fuller, bem a tempo da Exposição Universal. Downer (2013) afirma que toda Paris estava aos seus pés, enfeitiçada, pois ela representava a essência e a personificação do Japão. Citando as palavras de Morand (1900), Downer (2013, p. 292) escreveu: "Sada Yacco em Paris! Ninguém jamais imaginou que essas gravuras japonesas, que foram tão populares a ponto de estarem presente no portfólio de Clemenceau e nos estudos de Zola [...] um dia ganhariam vida". 
Figura 84 - Sada Yacco na capa da revista Le Théatre, 1900

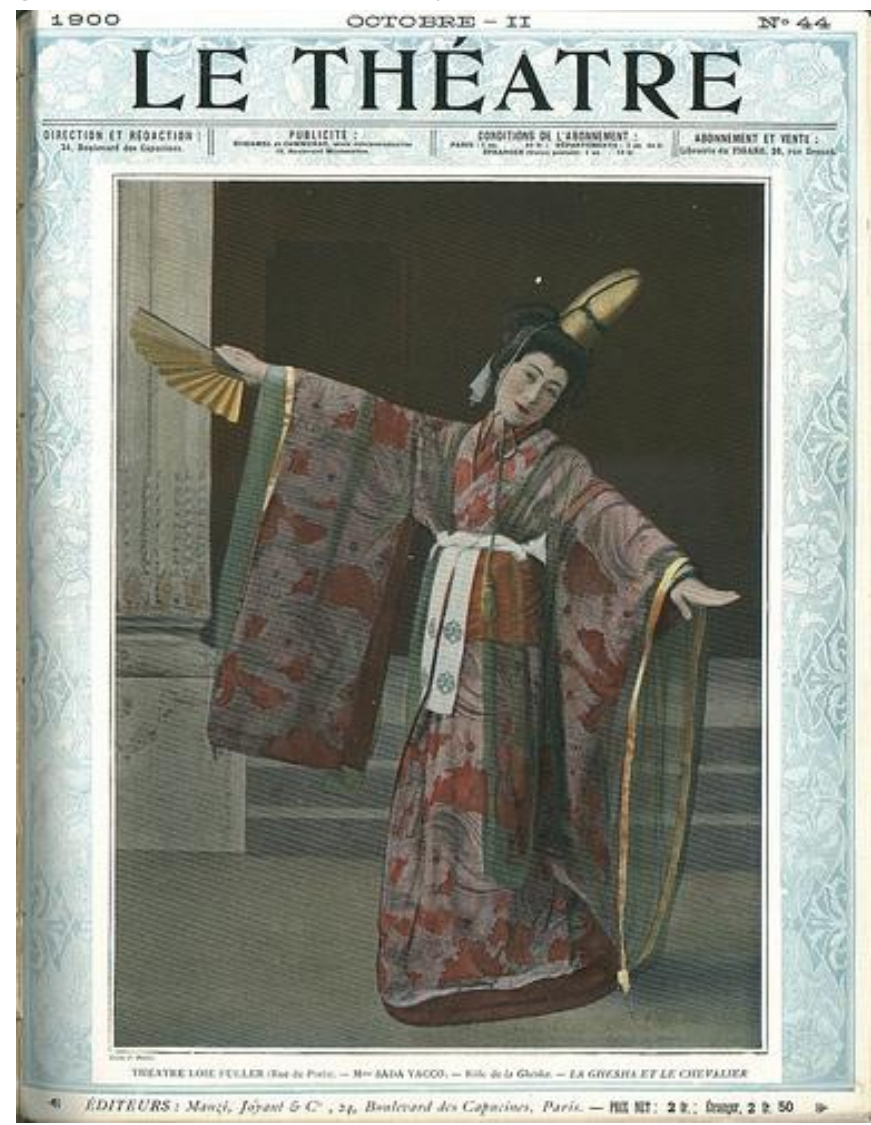

Fonte: https://www.flickr.com/photos/blue_ruin_1

Figura 85 - Sada Yacco por Pablo Picasso, 1901

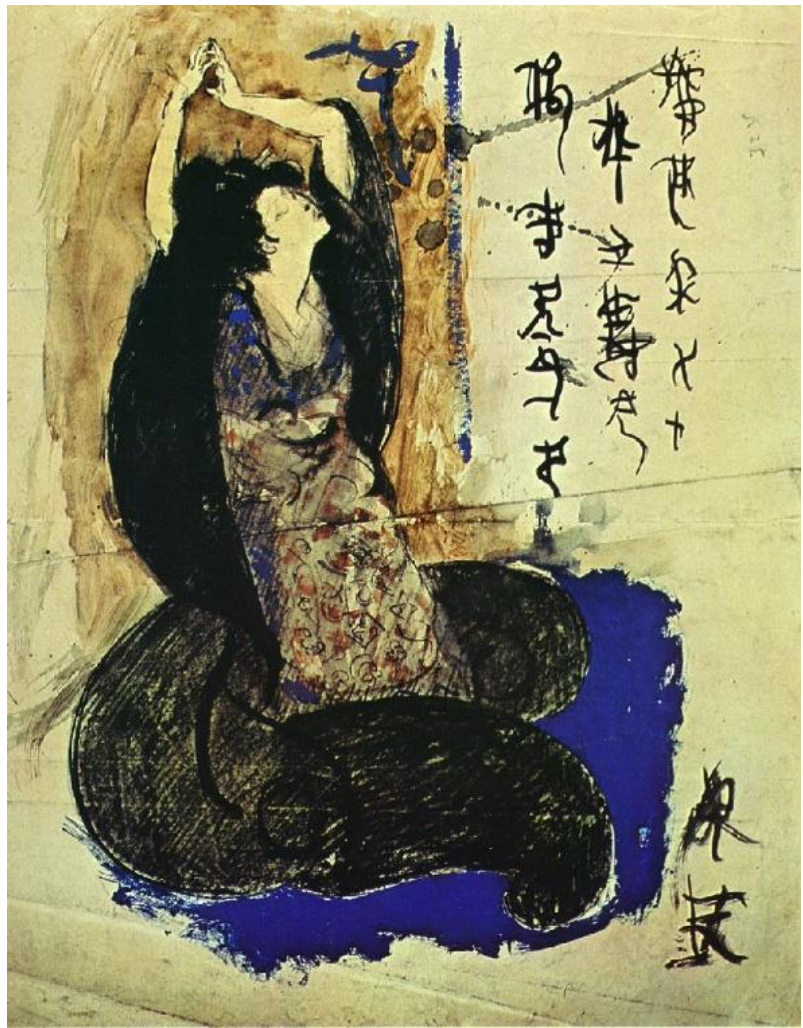

Fonte: www.wikiart.org 
Um dos motivos principais que a tornou tão especial foi sua maestria em trajar o quimono. Como possuia treinamento de gueixa, era espontâneo montar-se com naturalidade e refinamento, de modo que houve uma expansão do quimono em toda a França (FUKAl, 1994).

Os quimonos em geral eram bastante caros. Por serem itens de alta costura, ricamente bordados e de tecidos refinados, chegavam à Europa facilmente a um valor acima de 150 francos. A fim de capitalizar com a fama da atriz, a loja parisiense Au Mikado adquiriu os direitos de usar o nome "Yacco" e passou a oferecer diversos produtos assinados como, por exemplo, perfumes Guerlain, cremes, e até doces. Contudo, o artigo mais popular e que fez as mulheres sentirem-se próximas da estrela dos palcos veio a ser o "Quimono Sada Yacco", vendidos a um décimo do preço de um quimono original (DOWNER, 2003).

Vários anúncios publicitários foram impressos em revistas e periódicos. No anúncio abaixo (Figura 86) lê-se: "Pela simplicidade e originalidade do seu corte, com mangas amplas, os robes Sada Yacco estão obtendo um enorme sucesso ao fornecer um robe de interior mais gracioso e agradável”. Também anuncia que o corte e o tecido são autenticamente japoneses.

Figura 86 - Anúncio Quimono Sada Yacco, 1905

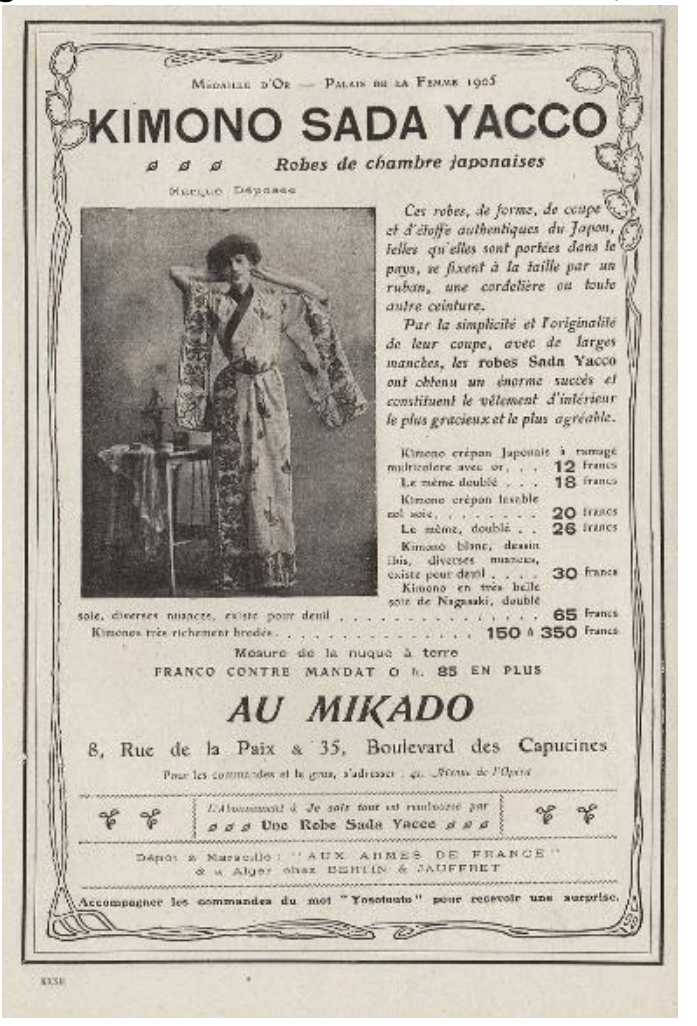

Fonte: http://www.ebay.com 
Figura 87 - Anúncio Quimono Sada Yacco, 1905

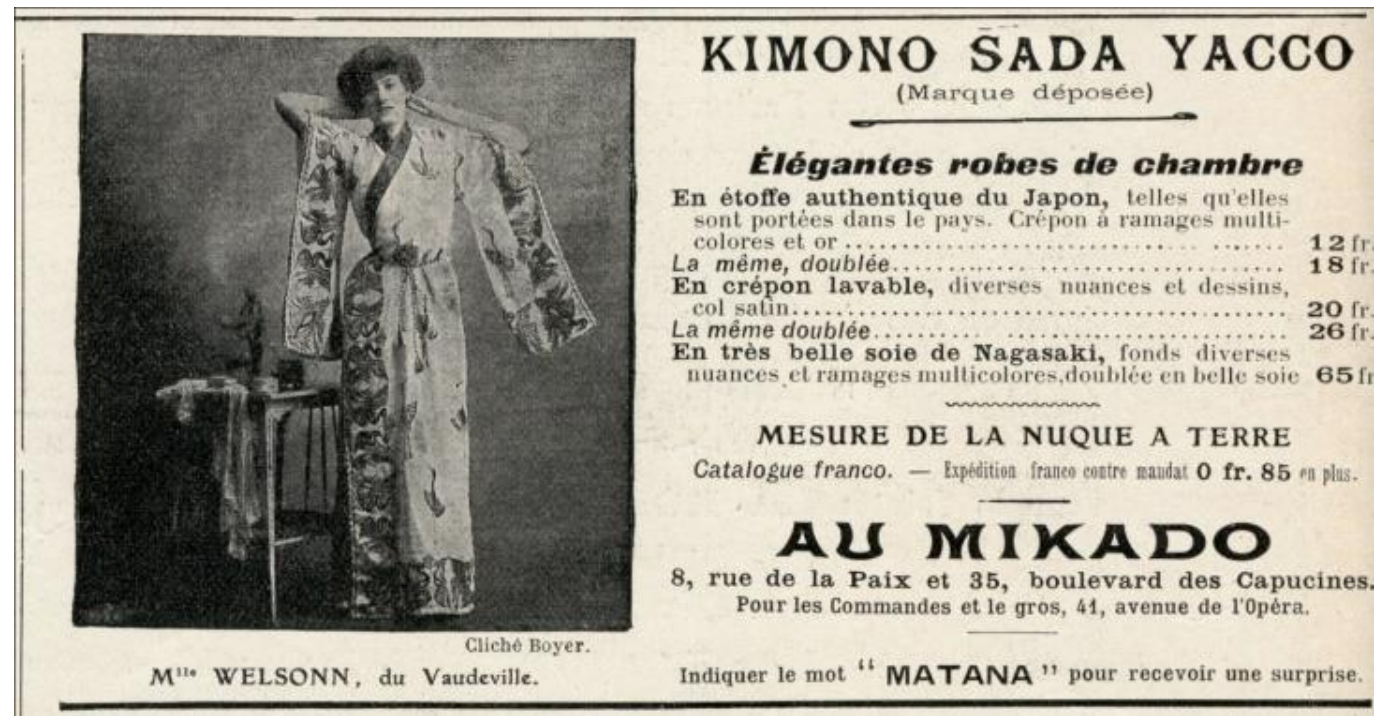

Fonte: http://www.ebay.com

A esse respeito Fukai (2007) informa que Vitaldi Babani é outro célebre nome na expansão do uso do quimono. Nascido no Oriente Médio, estabelece-se em Paris no ramo de importação, passando a comercializar quimonos adaptados ao mercado francês a partir de 1904. Seus quimonos eram fabricados com tecidos autênticos japoneses, de modo que os tornaram muito famosos.

Figura 88 - Anúncios de quimono de Babani, início do século XX
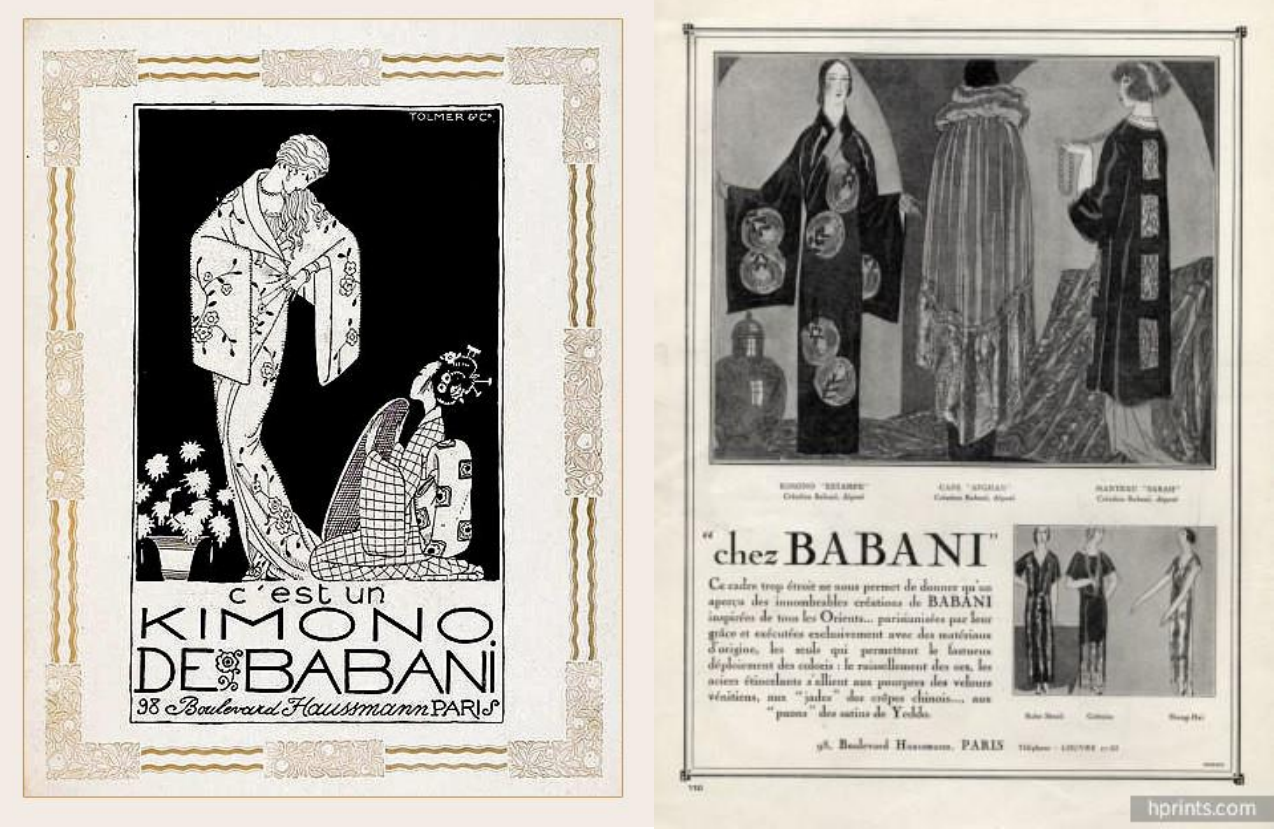

Fonte: http://hprints.com 


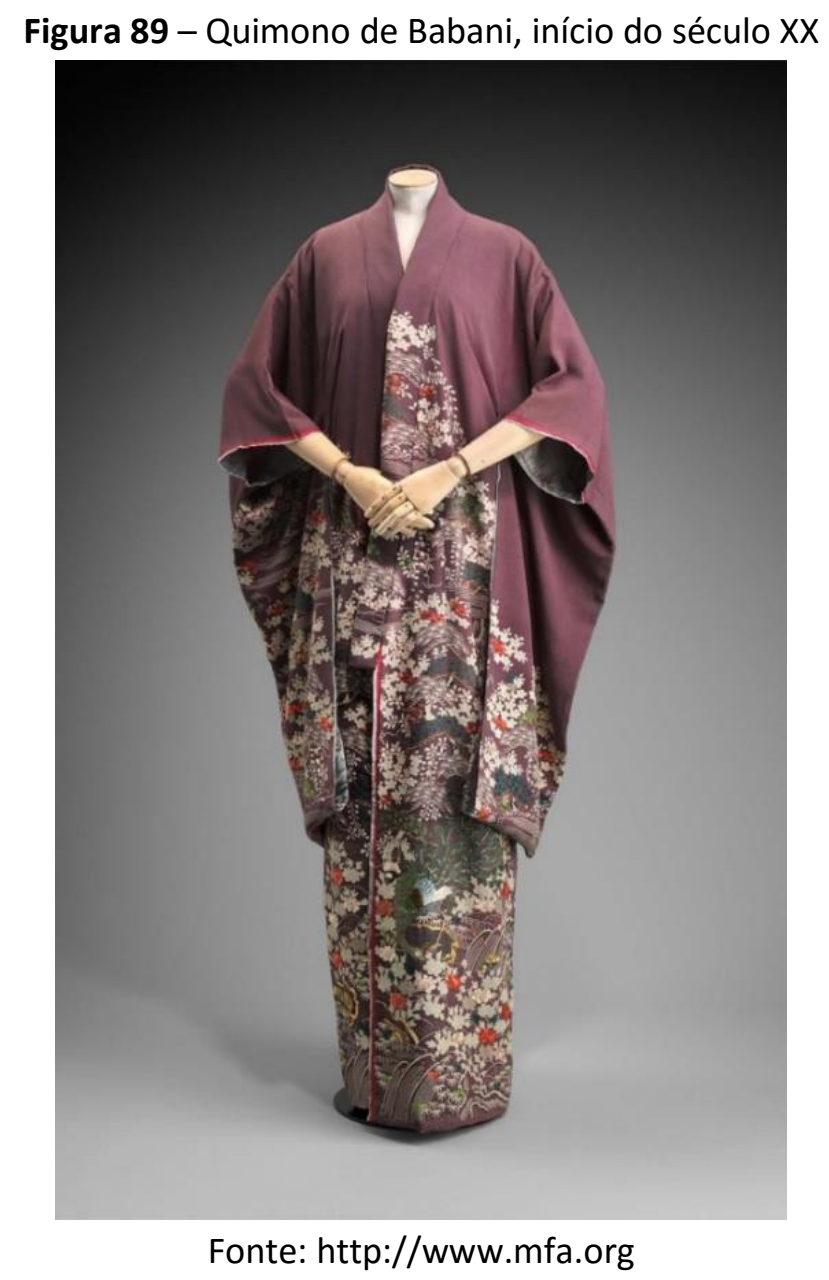

As fontes visuais reforçaram a percepção ocidental do quimono como apenas um roupão de banho ou como vestes de interior; na realidade, porém, esse suntuoso tipo de veste era utilizado em situações de grande formalidade, trajadas por mulheres da alta classe de militares japoneses (FUKAI, 1994). De acordo com Milhaupt (2014), muitos componentes derivaram de fato do modelo oriental; contudo, muitos detalhes na construção denunciam que os quimonos presentes no Ocidente eram claramente adaptados para atenderem às percepções ocidentais estereotipadas. Remodelados ao gosto europeu, o quimono era apreciado ao projetar um Japão ideal e imutável, de modo que sua função original possuiu pouca importância aos artistas, à população e às mídias impressas. 
Figura 90 - Le Jardin des Modes Nouvelles, 1913

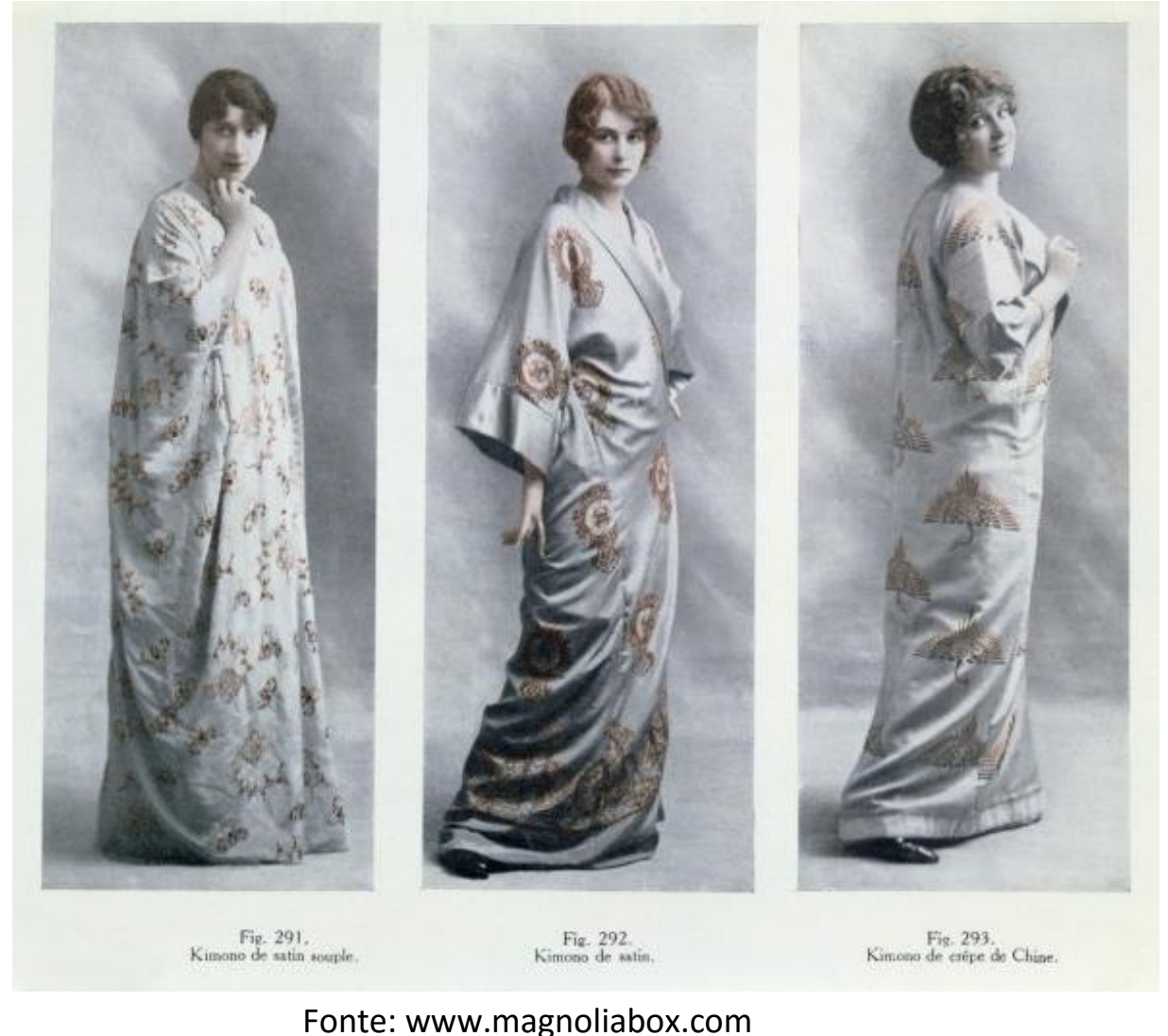

Fonte: www.magnoliabox.com

Milhaupt (2014) ainda acrescenta que, quando uma cultura se apropria de um objeto de outra cultura, ele, desvinculado de seu contexto social, econômico e político, passa a adquirir uma nova vida, de modo que sua função é adaptada e remodelada, muitas vezes distante de sua função primária. Apesar do esforço dos japoneses em exibir na Exposição Internacional de 1900 seus produtos industriais - caldeiras tubulares, altos-fornos, placa de armadura e armas -, em conjunto com artes e ofícios estritamente contemporâneos para refletir uma nação moderna, em pé de igualdade com o resto do mundo, para o Ocidente, todavia, interessava somente o Japão tradicional que evocava os tempos remotos das xilogravuras de madeira por eles tão adorados (DOWNER, 2013).

O Japão, atento a oportunidade comercial, seguiu em produção vertiginosa para atender ao mercado europeu, criando itens de consumo exclusivos para a exportação. Conforme Milhaupt (2014), a lida Gofukuten Takashimaya Company, fundada em 1831 em Quioto, é uma dessas empresas que se beneficia pelo fato de se estabelecer como um negócio independente de exportação direta ao desenvolver produtos de vestuário específicos para o mercado ocidental. O resultado seria um produto que, aos olhos ocidentais, seriam 
autenticamente japoneses, ao mesmo tempo em que com muita dificuldade seria reconhecido do mesmo modo pelos próprios. Tais alterações mostram que sua influência não dizia respeito à sua adoção pelos ocidentais e, sim, envolvia a incorporação de sua estética em um contexto pré-existente.

Figura 91 - Quimonos adaptados ao mercado ocidental, Takashimaya Co, 1900

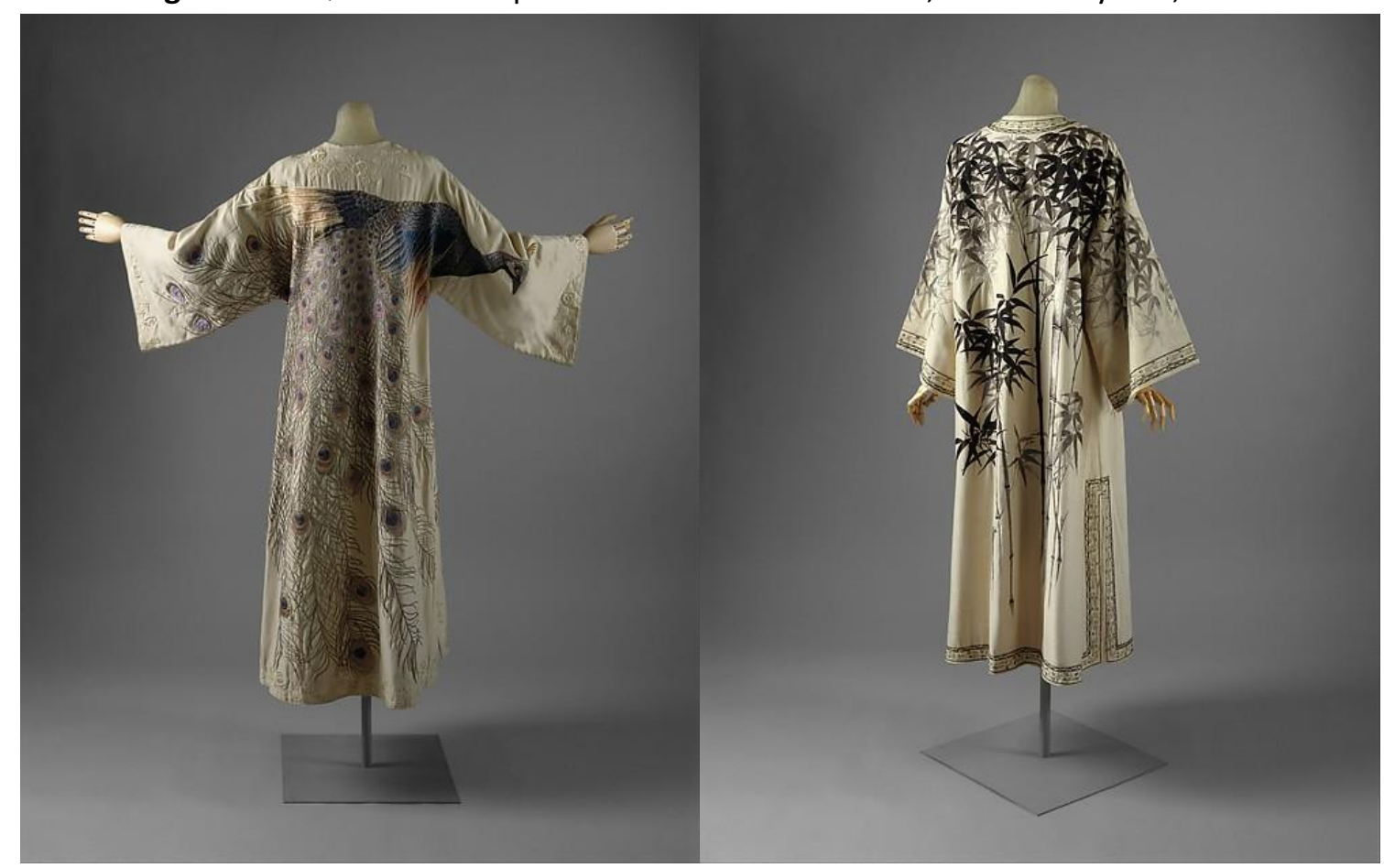

Fonte: http://www.metmuseum.org 
Figura 92 - Quimonos de Takashimaya Co, c. 1910

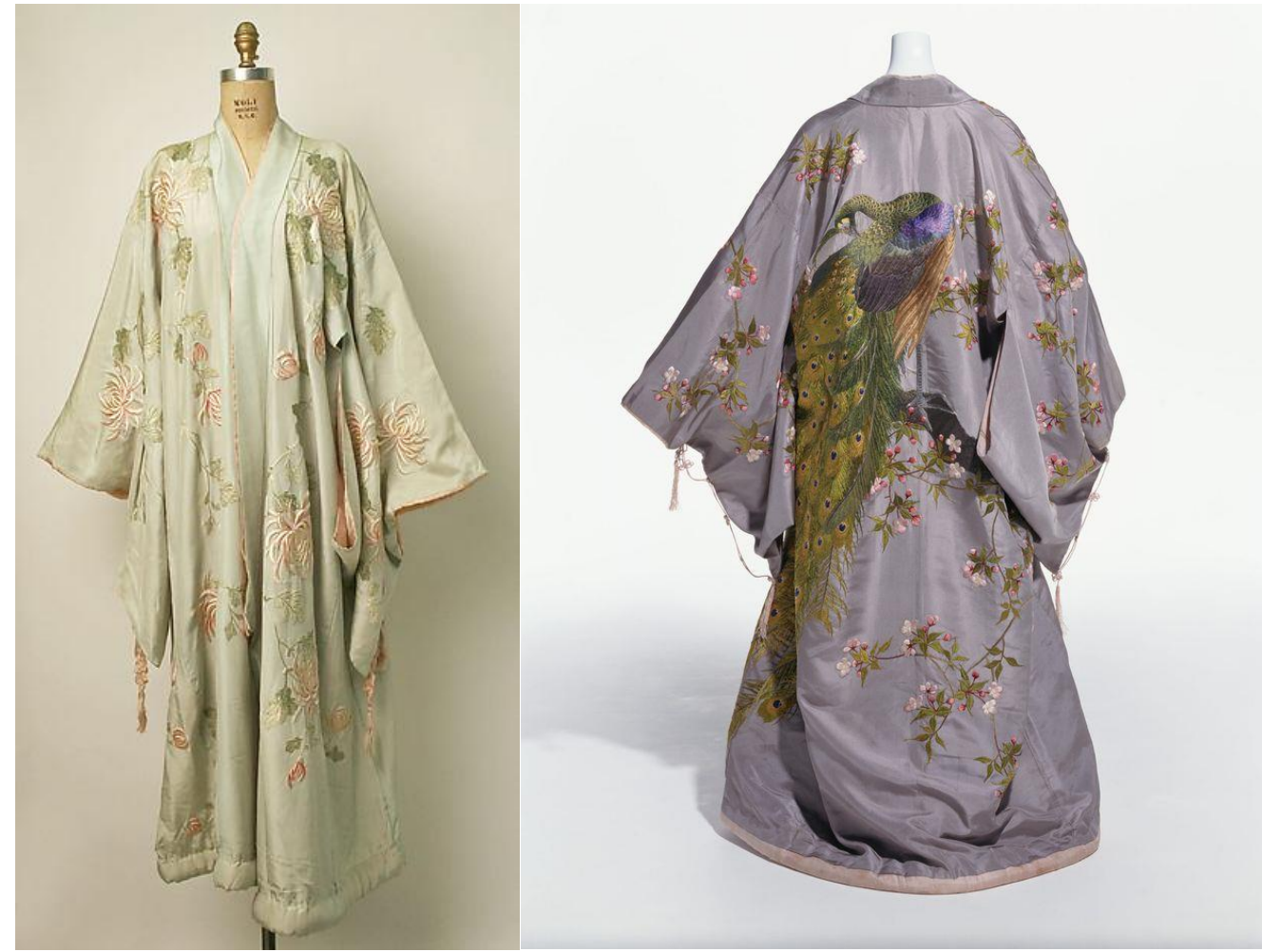

Fonte: http://www.metmuseum.org

Figura 93 - Robe de Chambre criado para o mercado Europeu. Tashimaya Co., c. 1906

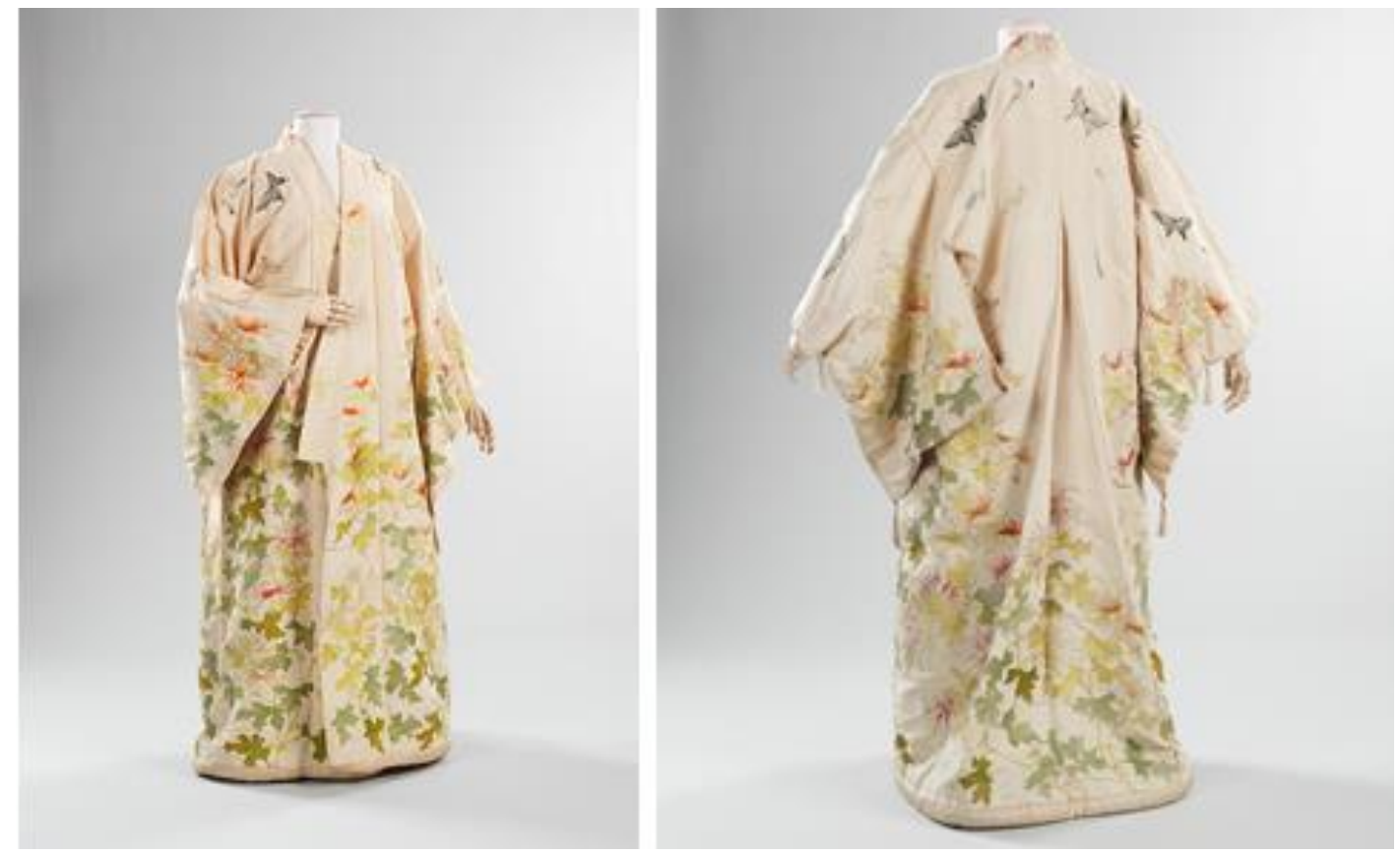

Fonte: http://www.metmuseum.org 


\subsubsection{Os motivos representativos japoneses}

Milhaupt (2014) acentua que a visibilidade do quimono em diversas obras impressionistas fornece evidências circunstanciais relacionadas entre si, como, por exemplo, a acessibilidade dos têxteis japoneses ao mercado internacional já a partir da metade do século XIX. Ainda segundo a mesma autora, os têxteis tornaram-se mais acessíveis por meio das lojas dos comerciantes Yamanaka Sadajiro e Nomura Shojiro, porque estes e outros reconheceram que o que tornava o quimono valioso era exatamente seu material.

Os diferenciados padrões decorativos, cores e técnicas obtiveram destaque na Exposição Internacional de 1878 (WICHMANN, 2007, p. 20):

Esses fantásticos e coloridos padrões, feitos de uma maravilhosa combinação de flores, juncos, pássaros voando e maravilhosas formações de nuvens, exercem um charme incomum, cheio de personalidade. As cores desses tecidos são de um requinte incomparável e representam a real importância de padrões - como deve ser o caso de uma estampa, afinal - que se dissipe no efeito global da peça. É possível ver combinações de cores tão exoticamente eficazes, de tal mordaz atração, que é fácil compreender a impaciência nas quais as mãos de finas moças chegam a essas peças requintadas.

Fukai (1994) afirma que os próprios quimonos frequentemente eram descosturados para a confecção de vestidos ocidentais, de modo que o Japonismo residiu não na estrutura, que permaneceu essencialmente ocidental, mas apenas no tecido utilizado (Figura 94). 
Figura 94 - Vestido construído a partir de um quimono. Turner, c. 1870

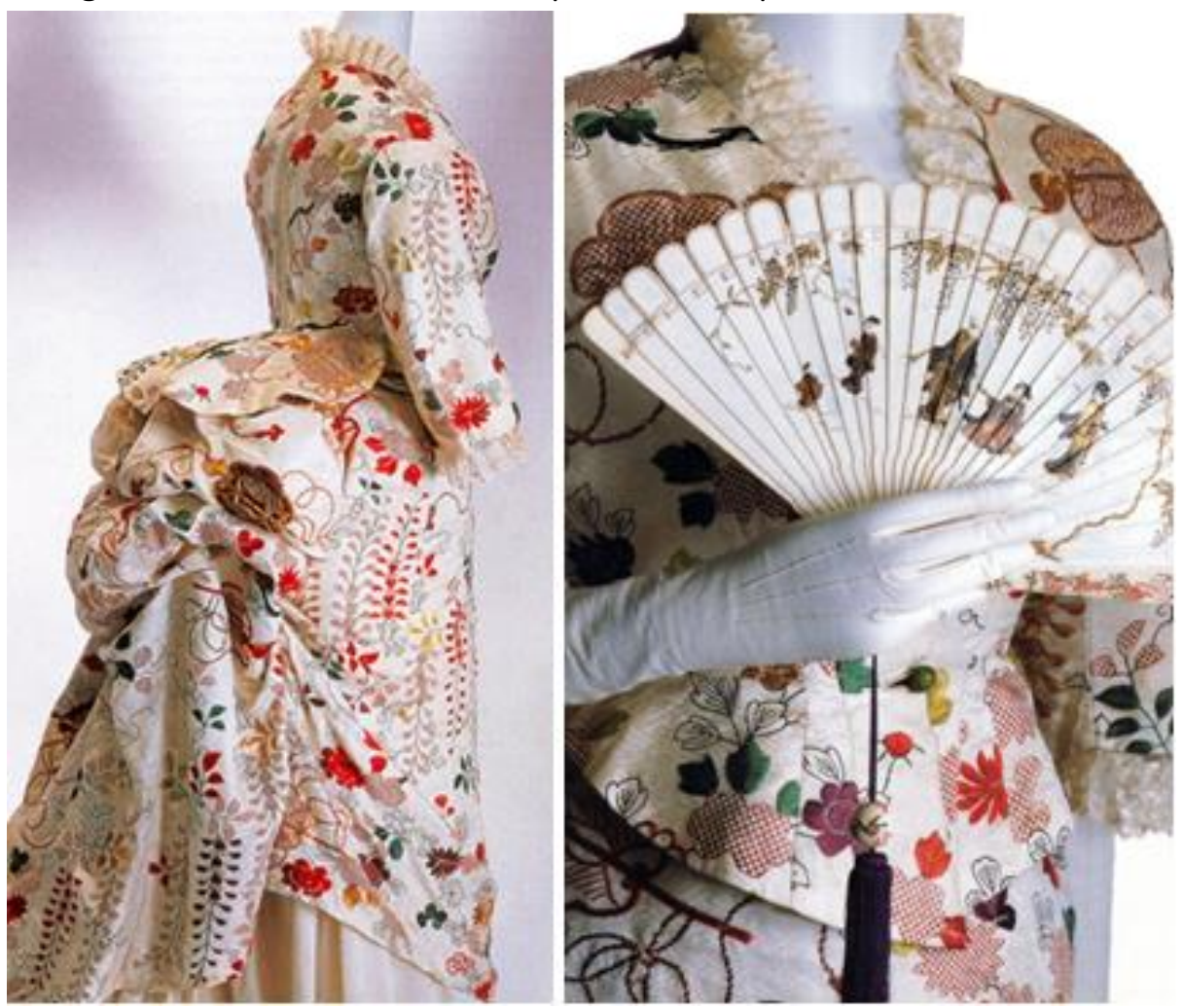

Fonte: https://afashionableexcuse.wordpress.com/articles-and-papers

Com ciência de que os padrões decorativos que se articulavam ao Japão estavam muito em voga na época, Fukai (1994), então, afirma que a empresa Takashimaya engajou-se também na produção de vestidos com silhueta ocidental. As peças elaboradas priorizavam motivos específicos como pássaros, florais e paisagens de notáveis locais nipônicos, ao mesmo tempo que possuíam características que nunca fizeram parte da realidade japonesa.

Os vestidos das figuras abaixo ficaram conhecidos como "Robes Yokohama" devido ao porto em que embarcavam, localizada na região metropolitana de Tóquio (METROPOLITAN MUSEUM OF ART, 2015).

Mesmo que o tecido e os bordados sejam genuínos japoneses, características evidentes da moda ocidental podem ser observadas, como o bustle, observado na Figura 95. Esses elementos foram estudados e inseridos a fim de provocar maior aceitação do público (FUKAI, 1994), e demonstram como o Japão interpretava e traduzia a moda ocidental. Segundo Geczy e Karaminas (2013b), o reconhecimento e a aprovação da França era a prioridade. 
Figura 95 - Robes Yokohama, 1875-1880

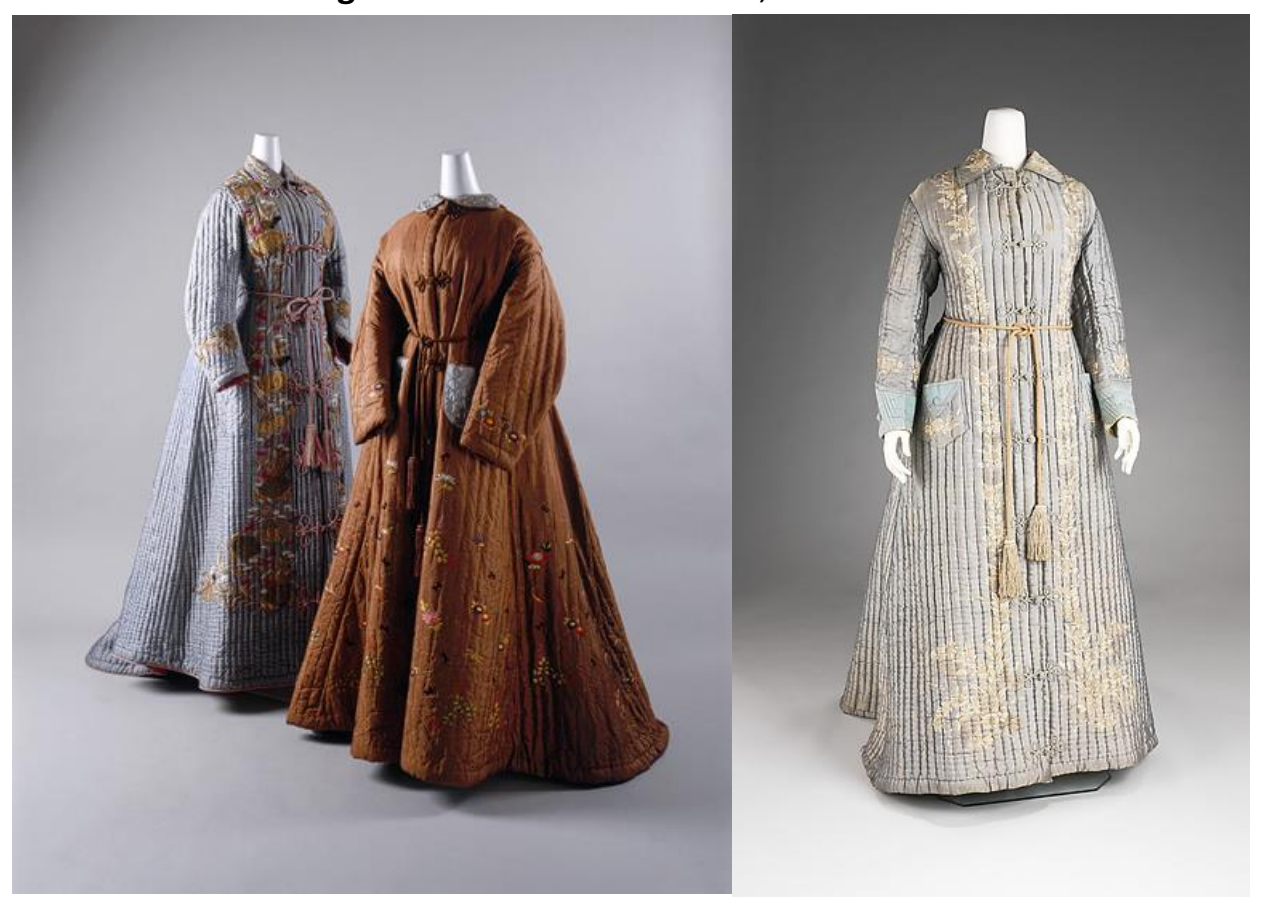

Fonte: http://www.metmuseum.org

Figura 96 -Vestidos japoneses para o mercado europeu, 1896-98

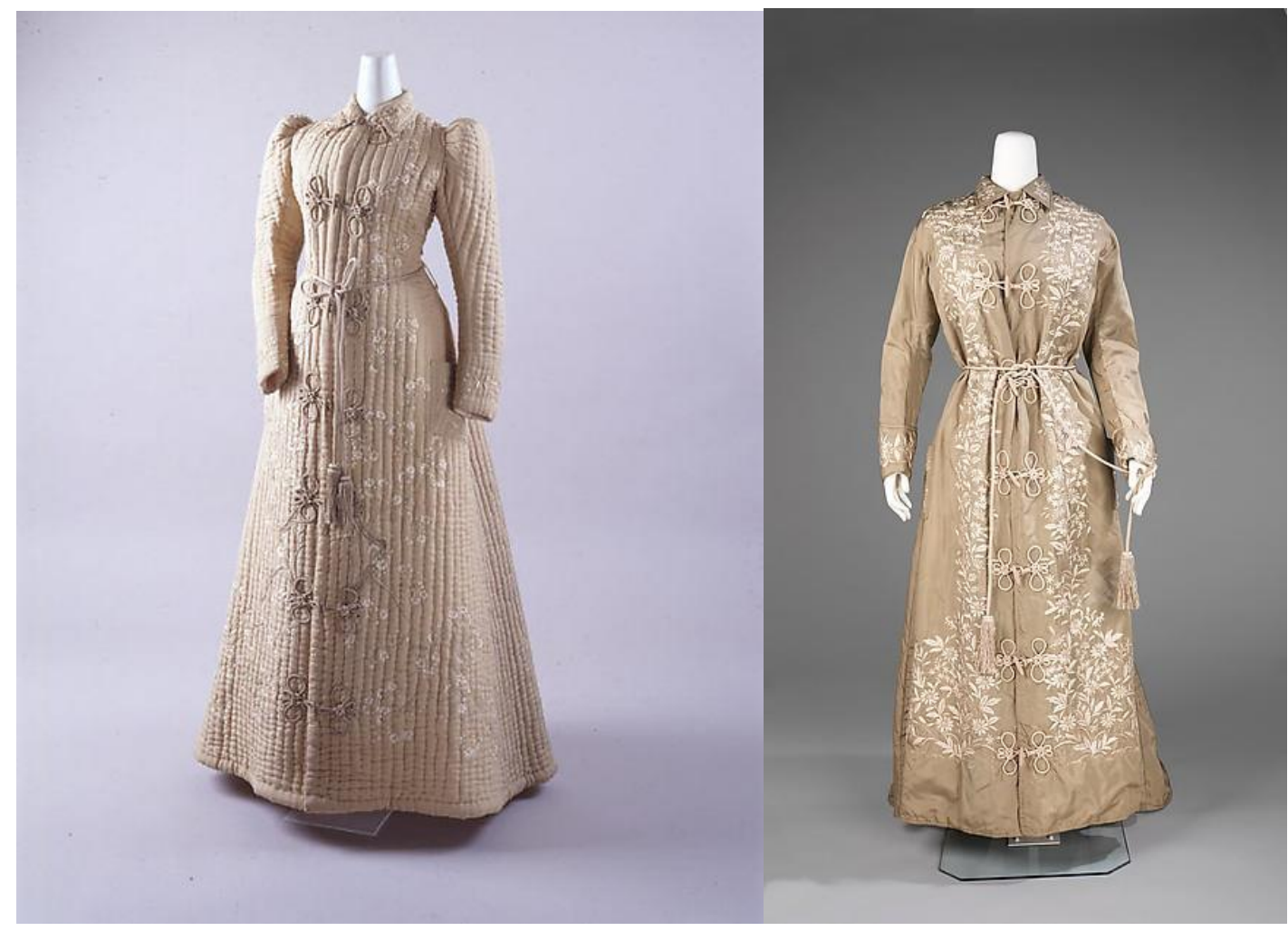

Fonte: http://www.metmuseum.org/collection/the-collection-online/search/84033 
Figura 97 - Robe Yokohama com bustle, 1879

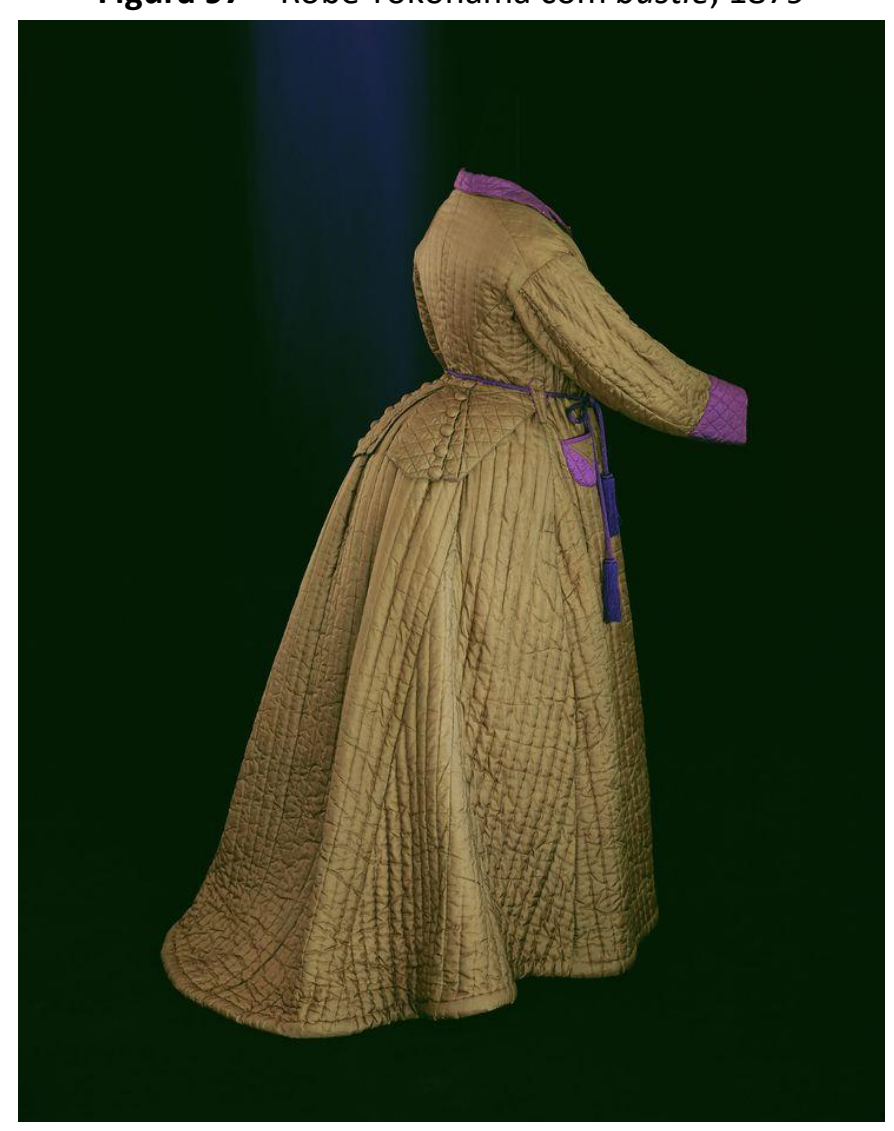

Fonte: Fukai, 2007, p. 264

Os designers ocidentais não poderiam e não ignoraram o fenômeno chamado Japonismo, de modo que motivos tipicamente orientais - flores, ondas, pássaros, gramíneas e outros motivos que demonstrassem afinidade com a natureza - foram deliberadamente tomados, emprestados e adaptados por diversos designers; assim sendo, passaram a incorporar os têxteis e o vestuário de toda a Europa e sua extensão territorial (ENGLISH, 2011).

A região francesa de Lyon, conhecida por sua produção de tecidos de seda desde o século XV, enfatizou esses motivos que, segundo Fukai (1994), demonstram uma clara mudança de estilo e design em comparação com as produções anteriores. As produções a seguir (Figura 98 e Figura 99) foram utilizadas na criação de coleções de alta costura parisiense no final do século XIX, de modo que atribuiu à estética e ao estilo japonês ainda maior popularidade. Por oportuno, a Prelle era uma das mais antigas manufaturas de tecidos. 
Figura 98 - Tecido de Eugène Prelle, Lyon, século XIX

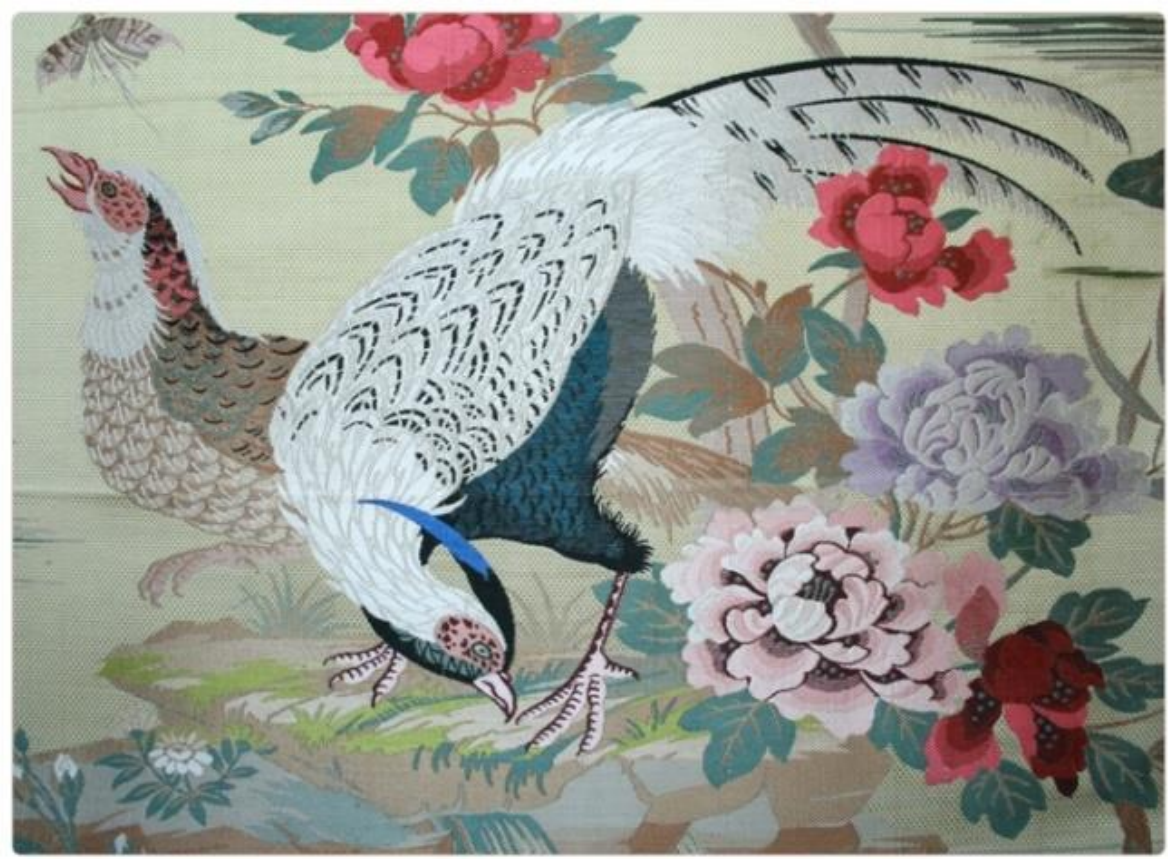

Fonte: http://www.prelle.fr

Figura 99 - Tecido adamascado de Eugène Prelle, Lyon, 1877

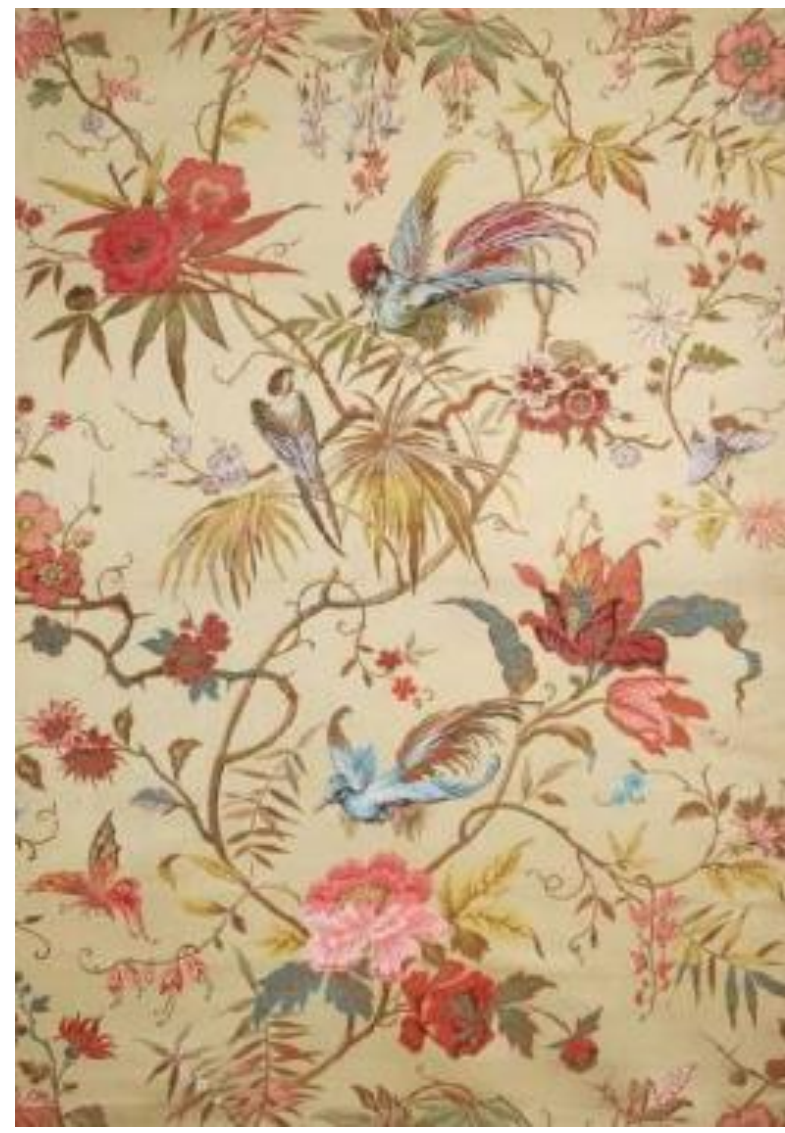

Fonte: http://www.prelle.fr 
A área francesa da Alsácia também foi uma das primeiras regiões da Europa a estabelecer relações diretas com o Japão na segunda metade do século XIX, possuindo o têxtil como uma das primeiras áreas de câmbio (MUSÉE MULHOUSE, 2015). Os motivos naturalistas e típicos japoneses tornaram-se fonte de inspiração para os designers têxteis. Uma pesquisa junto ao mu Museu de Mulhouse, permite constatar que, tamanha foi a influência do Japão no setor têxtil que o vocabulário têxtil japonês nessa região ainda permanece muito presente nos dias atuais.

Figura 100 - Impressão em rolo de lona de algodão, Alsácia, 1890

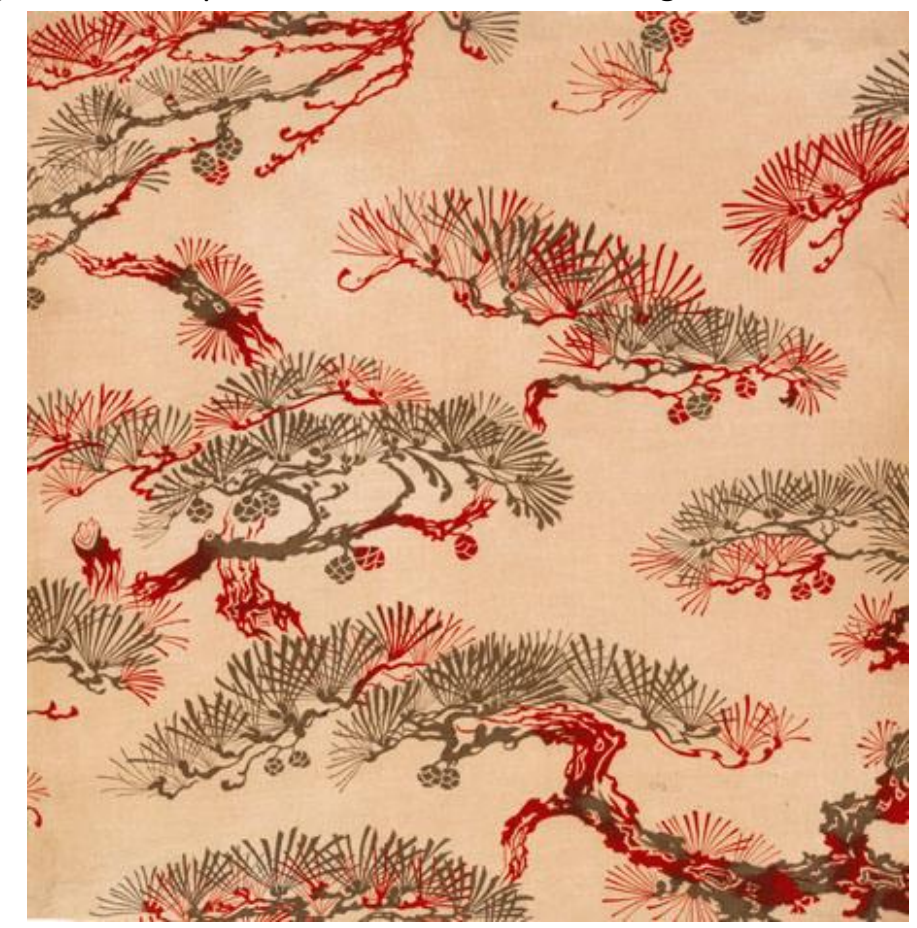

Fonte: http://www.proantic.com 
Figura 101 - Impressão de bloco em lona de algodão, Alsácia, 1889

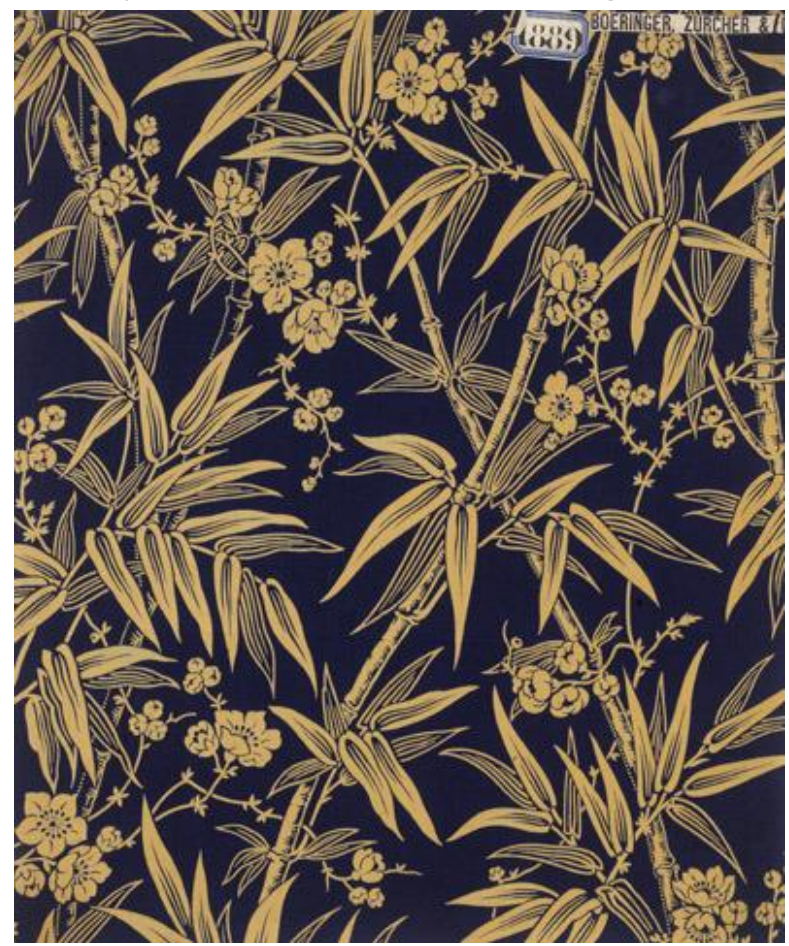

Fonte: http://www.proantic.com

Figura 102 - Amostra de móveis. Rolo de impressão sobre tela de algodão, 1870

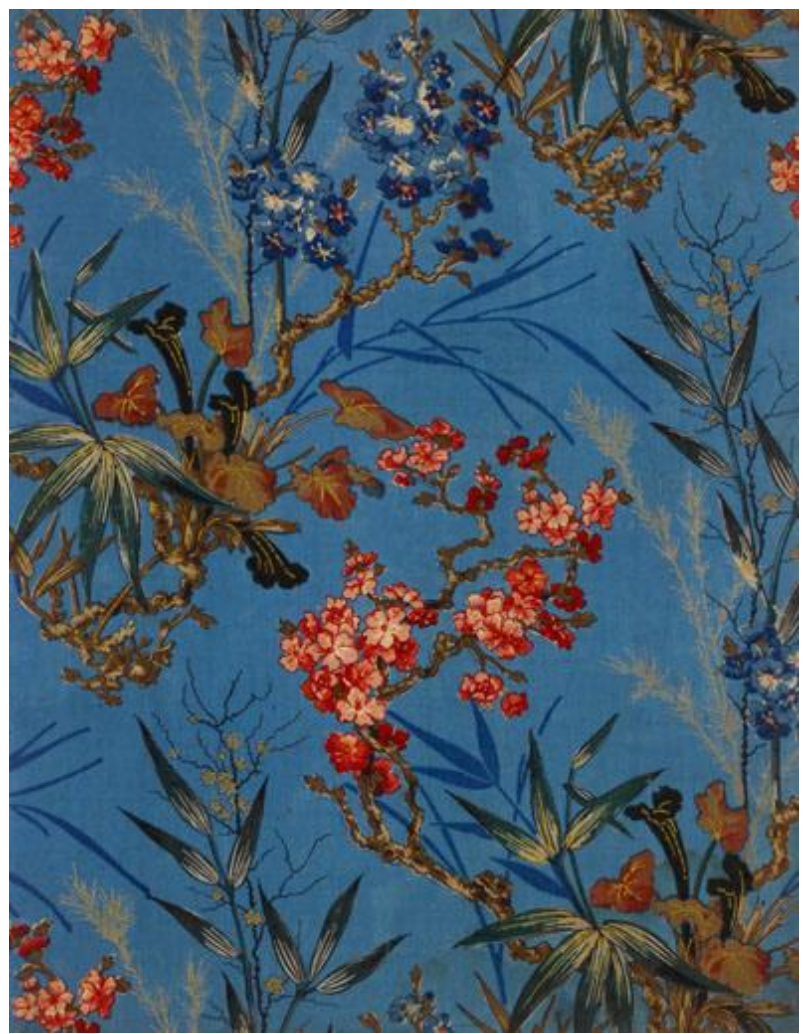

Fonte: http://www.proantic.com 
A foto abaixo, que mostra o tecido Papillons et Feiulles de Mauve de 1907 (Figura 103 à esquerda), é uma reprodução francesa de um têxtil do período Edo e foi utilizado em criações do designer Mariano Fortuny (1871-1949) na década de 1910. A versão original (Figura 103 à direita) apareceu na segunda edição do periódico Le Japon Artistique em 1888 (FUKAI, 2007).

Figura 103 - À esquerda, Papillons et Feiulles de Mauve, 1907, Bianchini Férier et Cie. À direita, têxtil produzido no período Edo, c. 1850

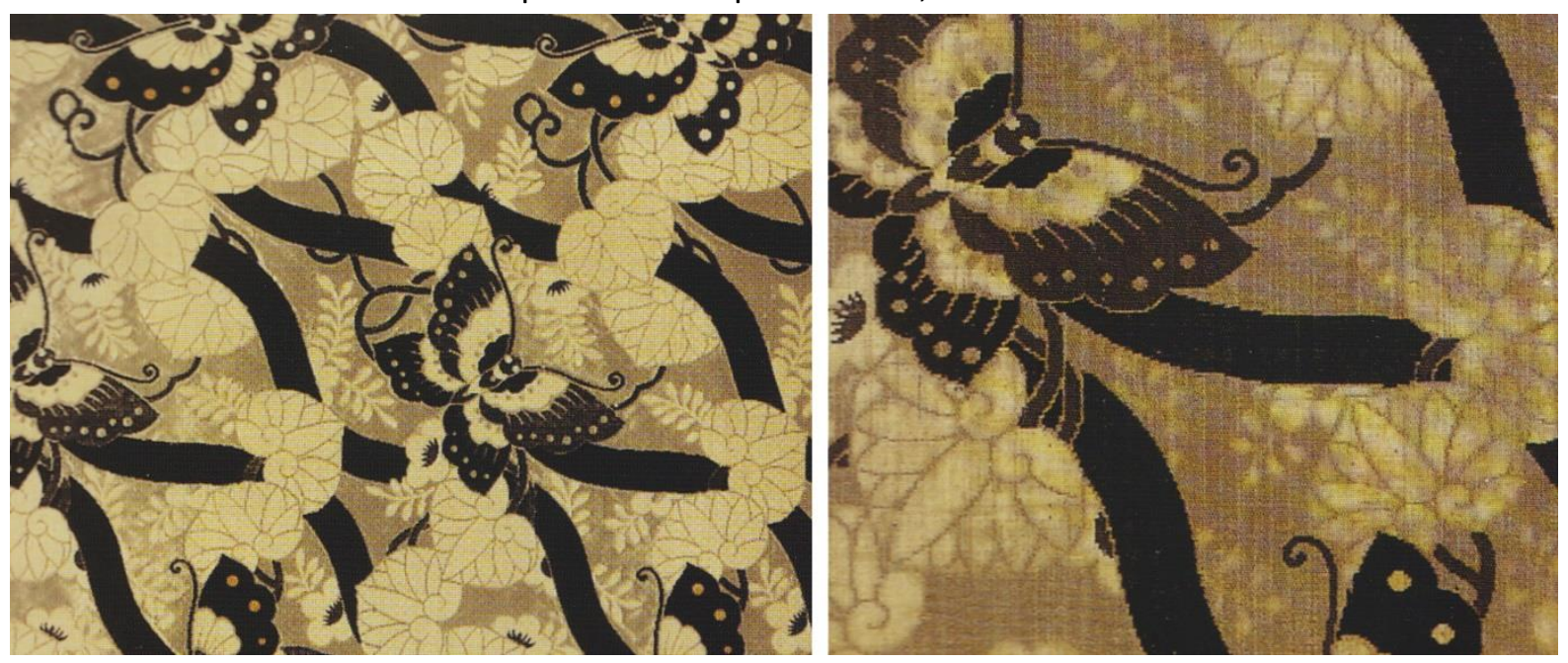

Fonte: Fukai, 2007, p. 234

Os têxteis desenvolvidos no Estúdio Silver, de 1880, um dos mais influentes da GrãBretanha entre 1890 e 1950, incorporaram os motivos e métodos de impressão japoneses para satisfazer o mercado britânico (MoDA, 2014). Na Figura 104, é possível perceber que o Mon, símbolo utilizado para designar os clãs familiares japoneses, foi adaptado como um elemento gráfico decorativo. 
Figura 104 - Estampa de Arthur Silver para Liberty \& Co., 1890

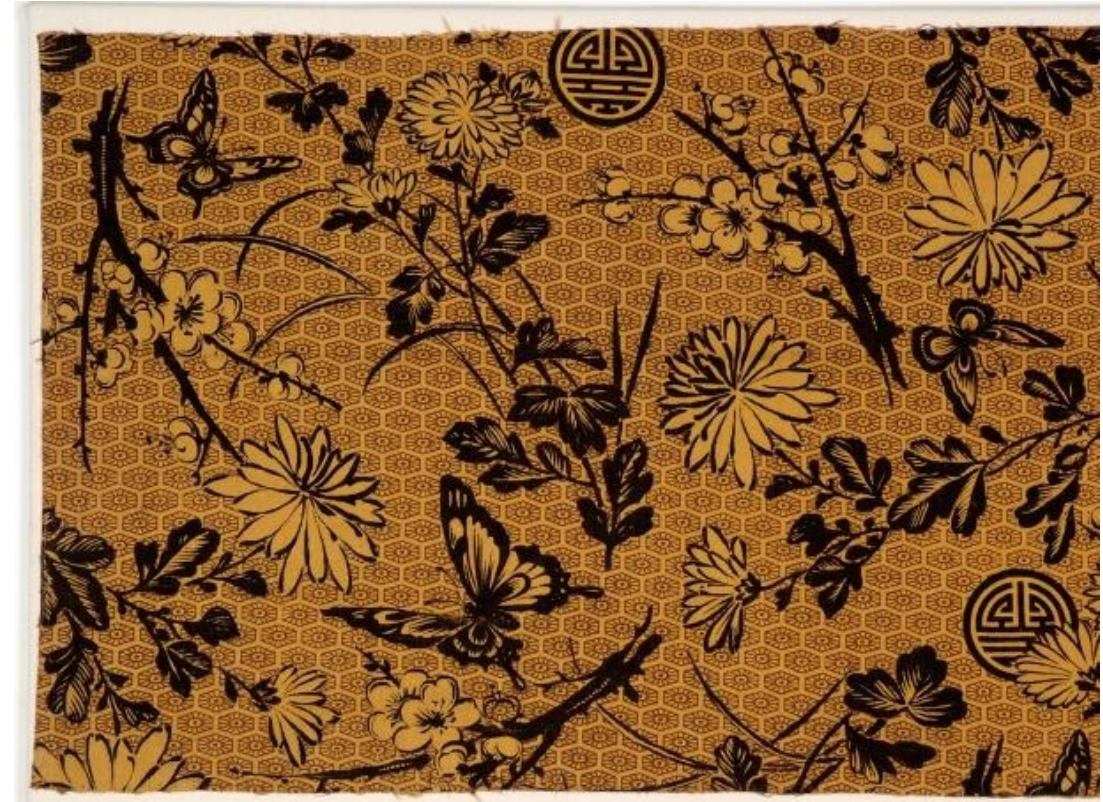

Fonte: http://www.moda.mdx.ac.uk/exhibitions/japantastic/content\#sthash.k6Zdo11h.dpuf

Esse estúdio também desenvolveu, no início de 1890, uma inovadora técnica de estêncil para o revestimento de paredes. O método, que proporciona efeito semelhante à técnica aplicada à mão, porém a custo reduzido, foi inspirado nos estênceis nipônicos (MoDA, 2014), configurando-se um belo exemplo de como pode ser aplicada a adaptação de ideias japonesas.

A F. Steiner \& Co é outra companhia têxtil britânica que, desde a década de 1870, utiliza a influência japonesa em suas produções. O designer Christopher Dresser (1834-1904), o responsável pelo desenvolvimento das estampas abaixo, possuía grande fascinação pelo país, principalmente devido a habilidade do artesão japonês na representação das formas da natureza. Seu livro Japão: sua arquitetura, arte e manufatura, resultante de sua viagem ao país em 1876, ajudou a reforçar o Japonismo no final do século XIX (OSHINSKY, 2000), e, no dizer de Morley (2012), ao mesmo tempo em que influenciou toda uma geração de designers, incluindo Morris, Godwin, Tiffany, Gallé, Loetz, Liberty, o Estúdio Silver, entre outros. 
Figura 105 - Japão: sua arquitetura, arte e manufatura. Christopher Dresser, 1882

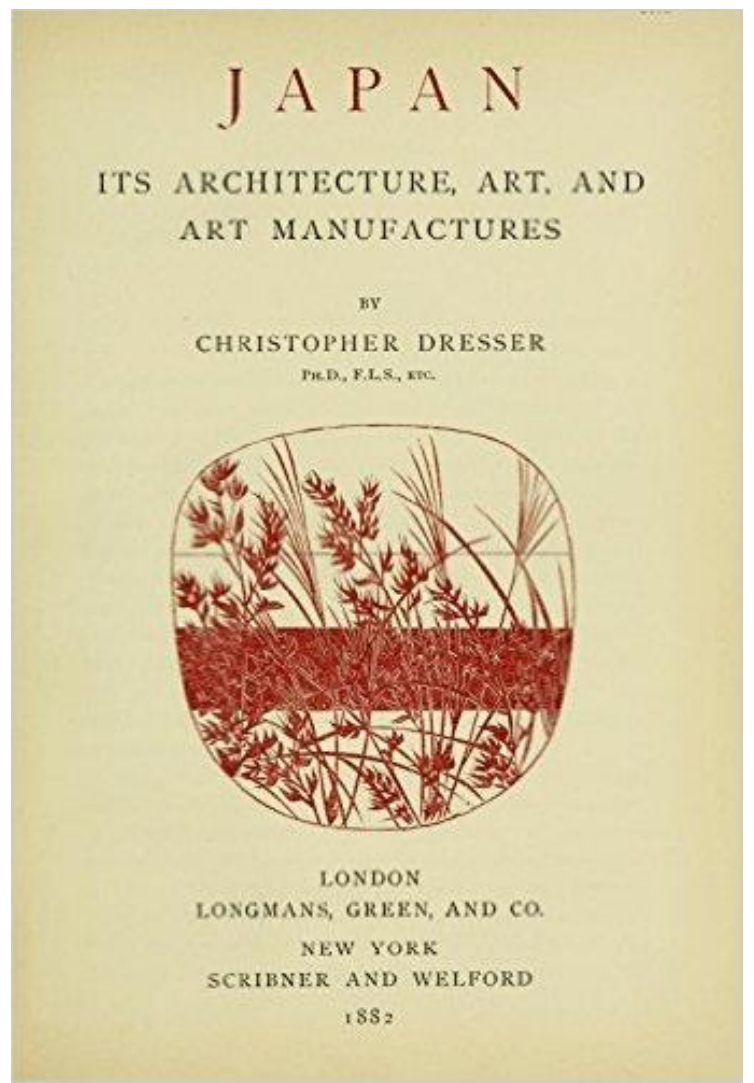

Fonte: http://www.christopherdresser.co.uk

Figura 106 - Christopher Dresser. Steiner \& Co, 1902

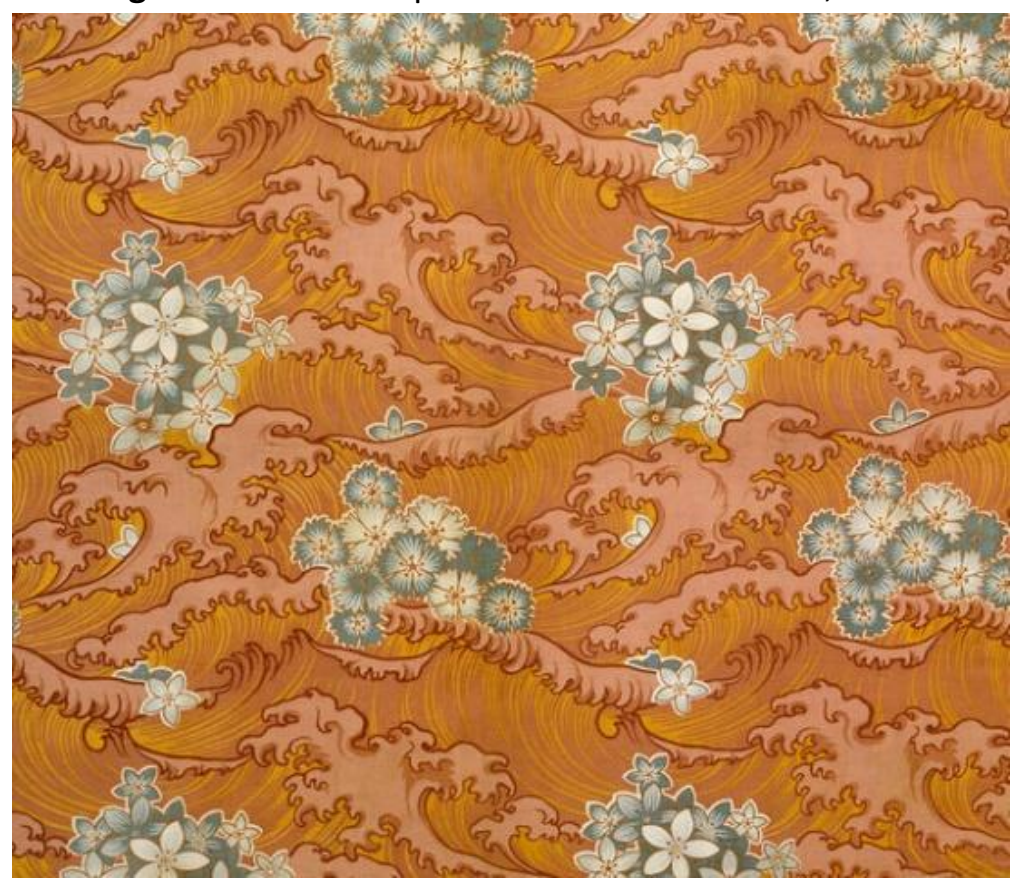

Fonte: http://collections.vam.ac.uk/item/016652/furnishing-fabric-dresser-christopher 
Figura 107 - Christopher Dresser, c. 1898

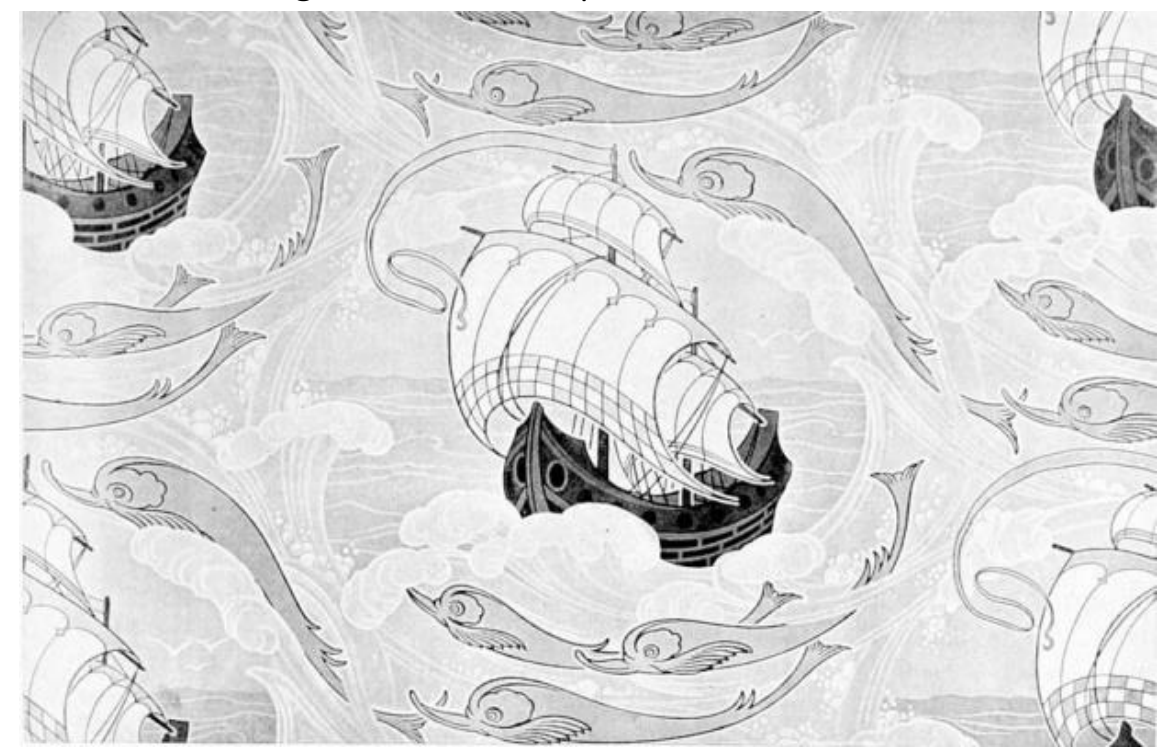

Fonte: http://www.victorianweb.org/art/design/textiles/dresser.html

Figura 108 - Christopher Dresser, 1871

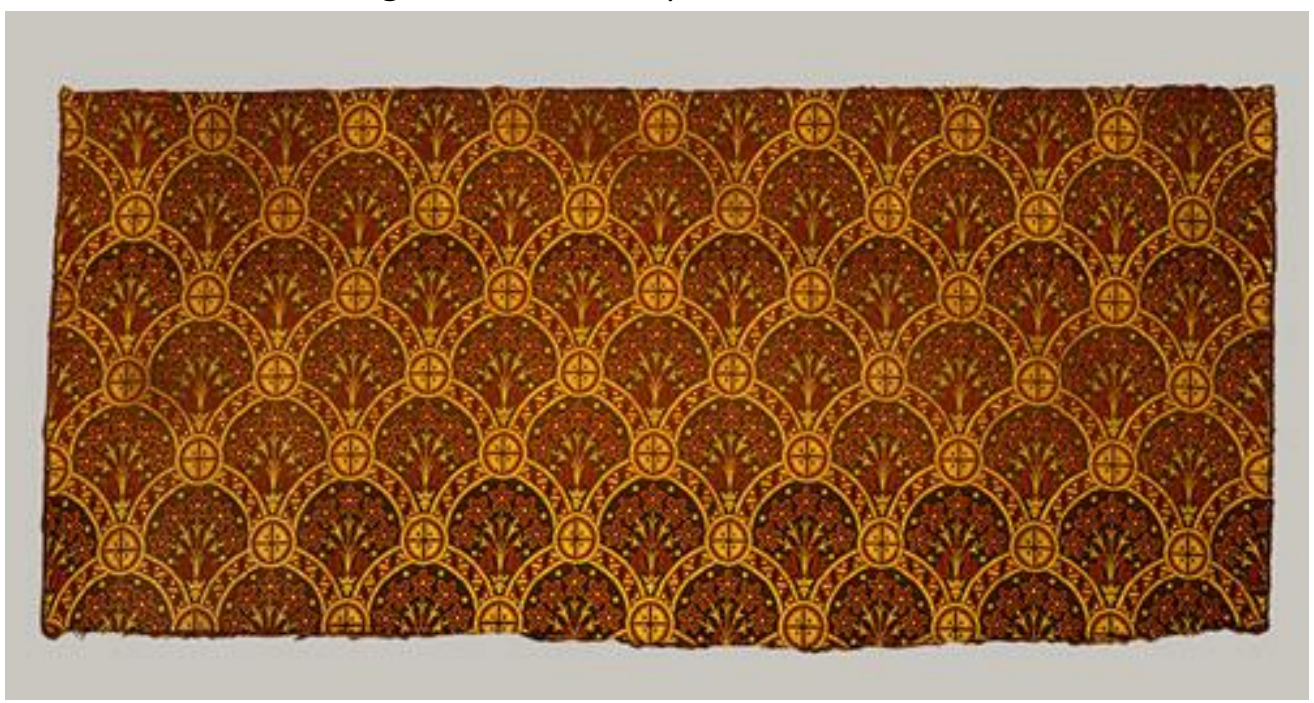

Fonte: http://www.metmuseum.org/toah/works-of-art/1984.469

Ainda na Inglaterra, Pezzolo (2013) afirma que os motivos florais provenientes do Japão inspiraram o comerciante inglês Arthur Liberty (1843-1917) na criação das estampas Liberty \& Co, por sinal, populares até hoje.

O mesmo processo de contágio se cruzava em paralelo com as peças de vestuário produzidas Europa. É possível observar no detalhe do catálogo de 1898 do anúncio da Liberty \& Co. (Figura 109) a descrição em inglês, dando a entender que o shape, o estilo e o fitting foram adaptados para o uso ocidental. 
Figura 109 - Catálogo de natal Liberty \& Co., 1989

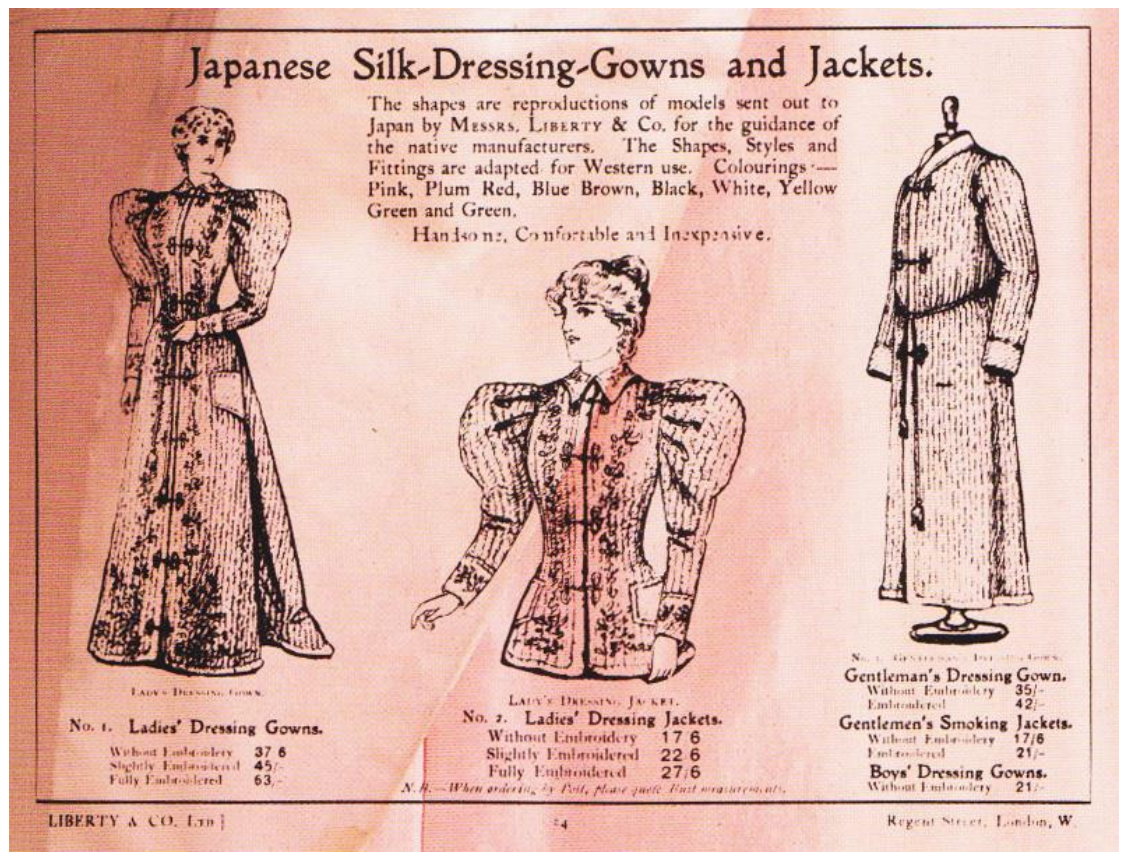

Fonte: Fukai, 2007, p. 266

O famoso designer parisiense Jacques Doucet (1853-1929), um profundo apreciador e conhecedor das artes, não tardou a incorporar elementos japoneses como o ayame (íris japonês) e o bambu (FUKAl, 2007).

Figura 110 - Vestidos de Jacques Doucet, final do século XIX

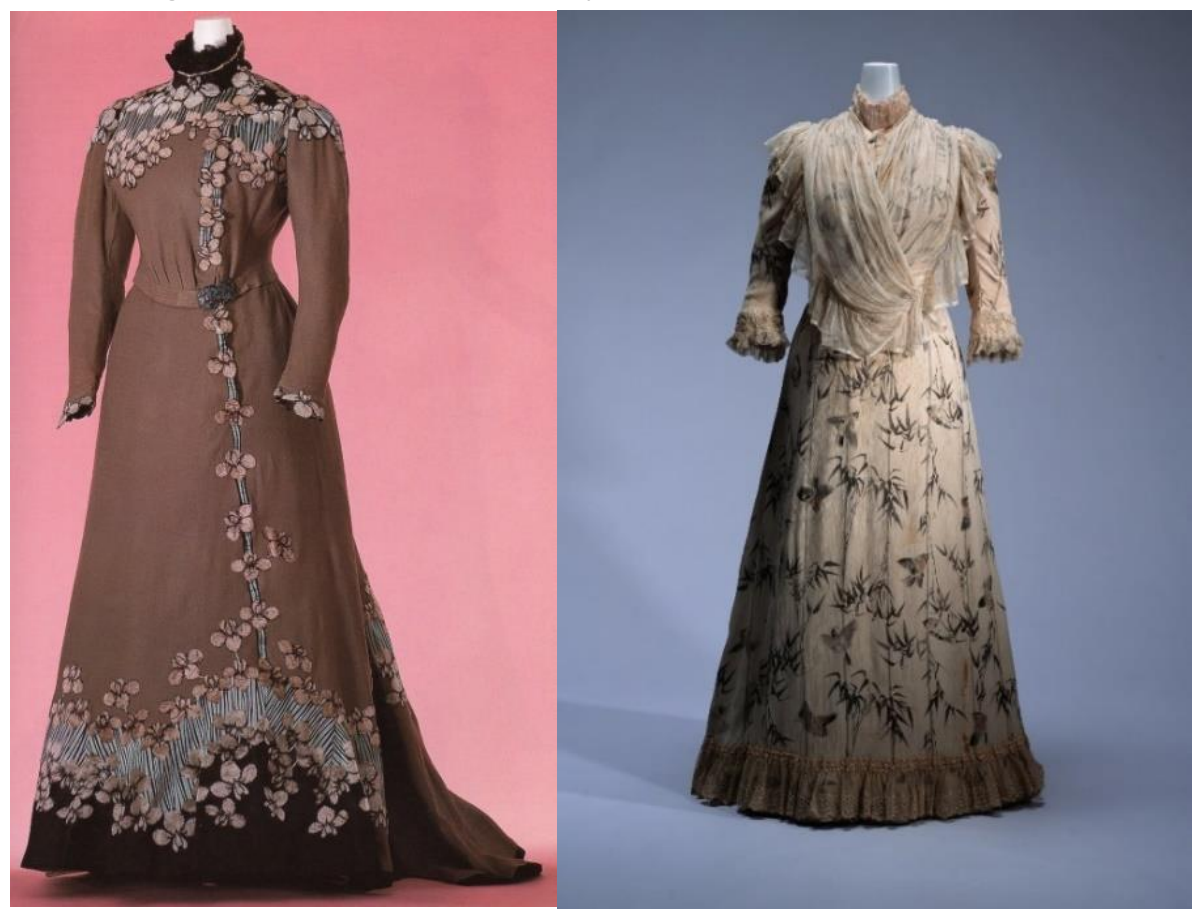

Fonte: http://www.kci.or.jp 
O crisântemo, um dos motivos florais mais emblemáticos da cultura japonesa, reafirmado em 1887 pela obra de Pierre Loti, Madame Chrysanthème, já mencionado em páginas anteriores, surge frequentemente na moda. Fukai (2007) destaca que o bordado do vestido mostrado abaixo utiliza uma técnica japonesa, o nikuiri-nui.

Figura 111 - Vestido do século XIX

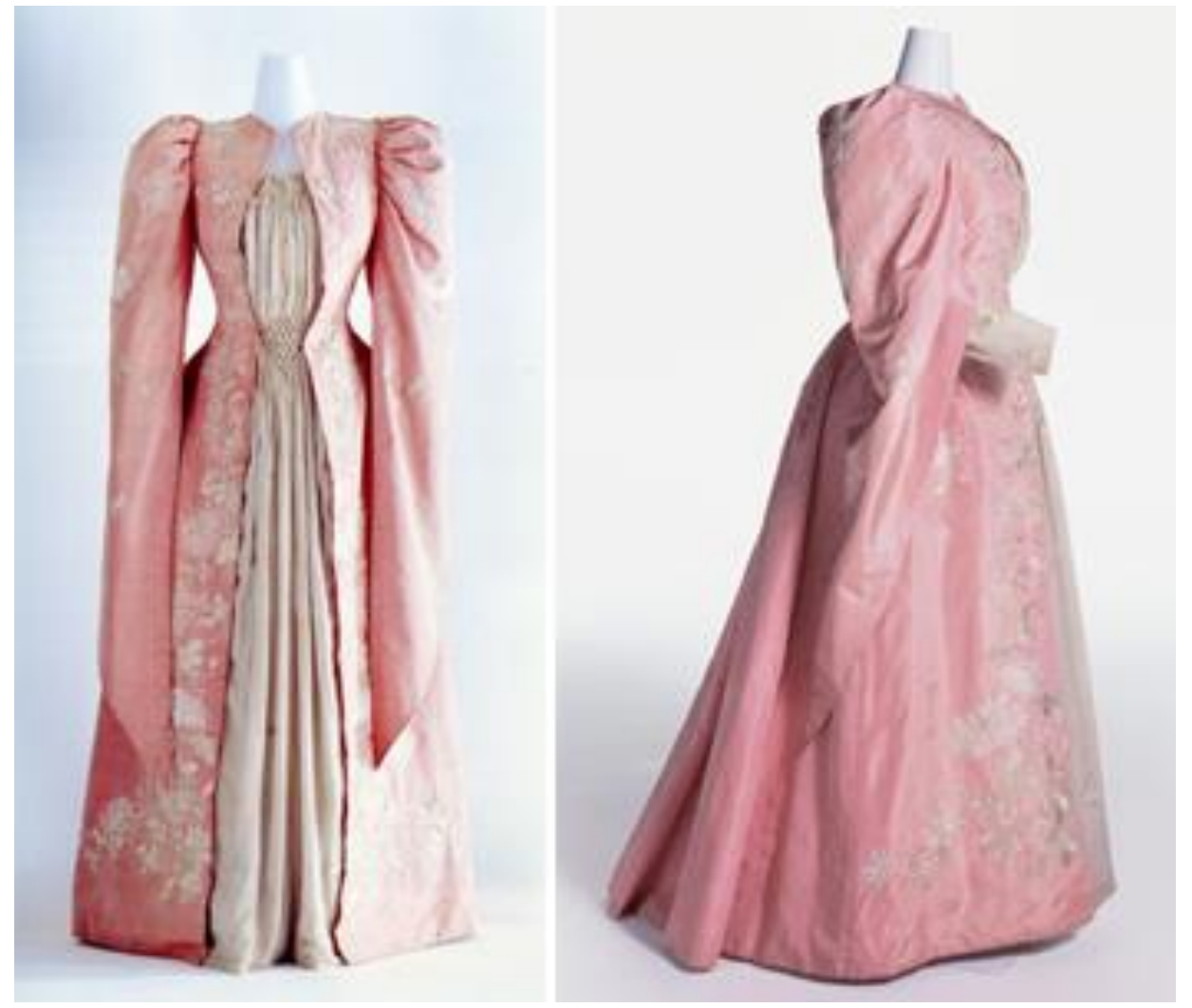

Fonte: http://www.kci.or.jp/archives/digital_archives/detail_222_e.htm

Em 1858, Charles-Frédéric Worth (1825-1895) promove o sistema que, posteriormente, seria denominado Alta-Costura. Diferentemente do trabalho de alfaiate, ao qual se atribui a tarefa de execução, Worth desenvolve modelos inéditos, idealizados por ele, configurando-se como criador e não somente como executor, representando a autonomização do costureiro. Dessa forma, ele estabelece o conceito de grife, uma obra assinada, assim como fazem os pintores em suas obras (TORTORA; EUBANK, 2005).

A Maison Worth se estabelece como a mais célebre casa de Alta-Costura da época, de modo que, na busca de renovados motivos para suas coleções, volta-se frequentemente para o Japão, depositando ainda mais credibilidade nessa tendência. A esse respeito, Geczy e Karaminas (2013b), enfatizam que a utilização do crisântemo (Figura 112) e da borboleta 
(Figura 114) como símbolos de contemporaneidade e exotismo, confirma a moda japonesa não somente como exótica, mas também como sinônimo de autenticidade.

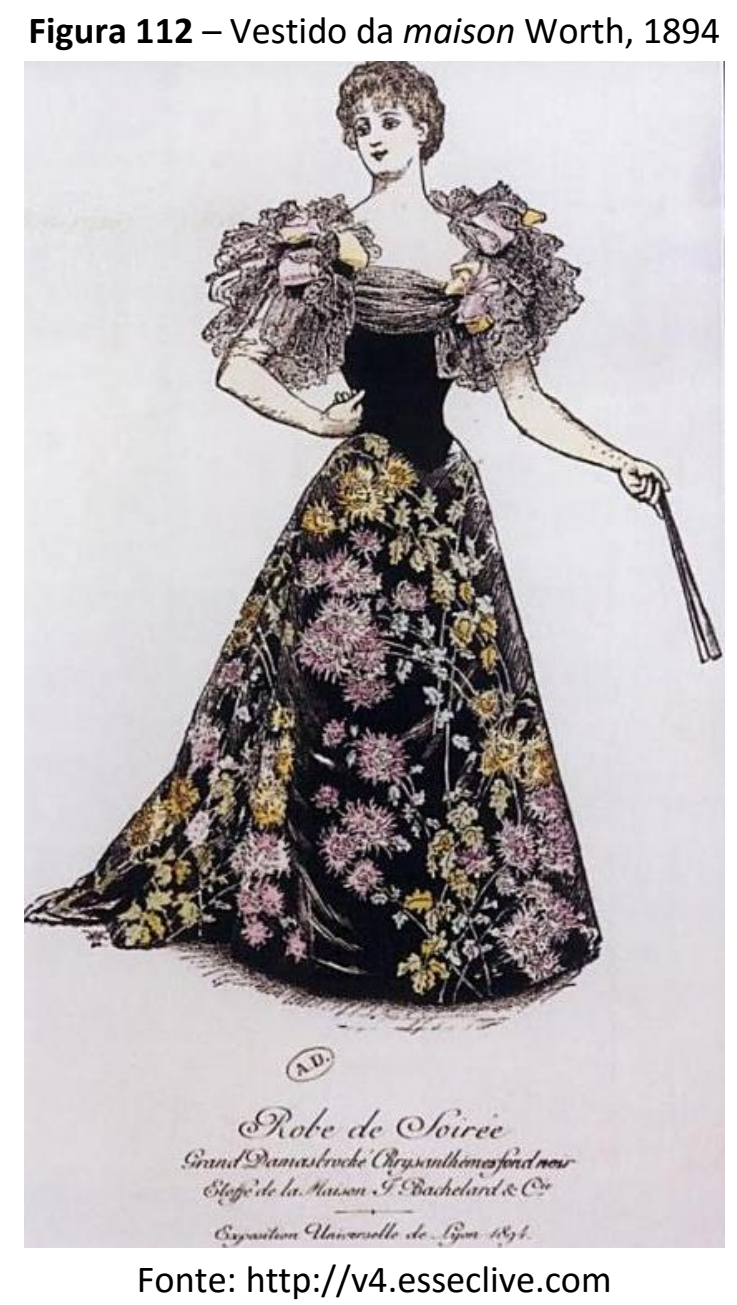

Wichmann (2007) afirma que a borboleta provoca um grande apelo para a imaginação do povo Oriental, pois se acredita que ela traz sorte e proteção, relacionada também com o sonho e a felicidade. A famosa ópera Madame Butterfly de Puccini, reforçou a figura da borboleta como um forte símbolo representativo nipônico, ao mesmo tempo em que se tornou um ícone europeu da virada do século. 
Figura 113 - Gravura Borboleta e Libélula. Kitagawa Utamaro, 1788

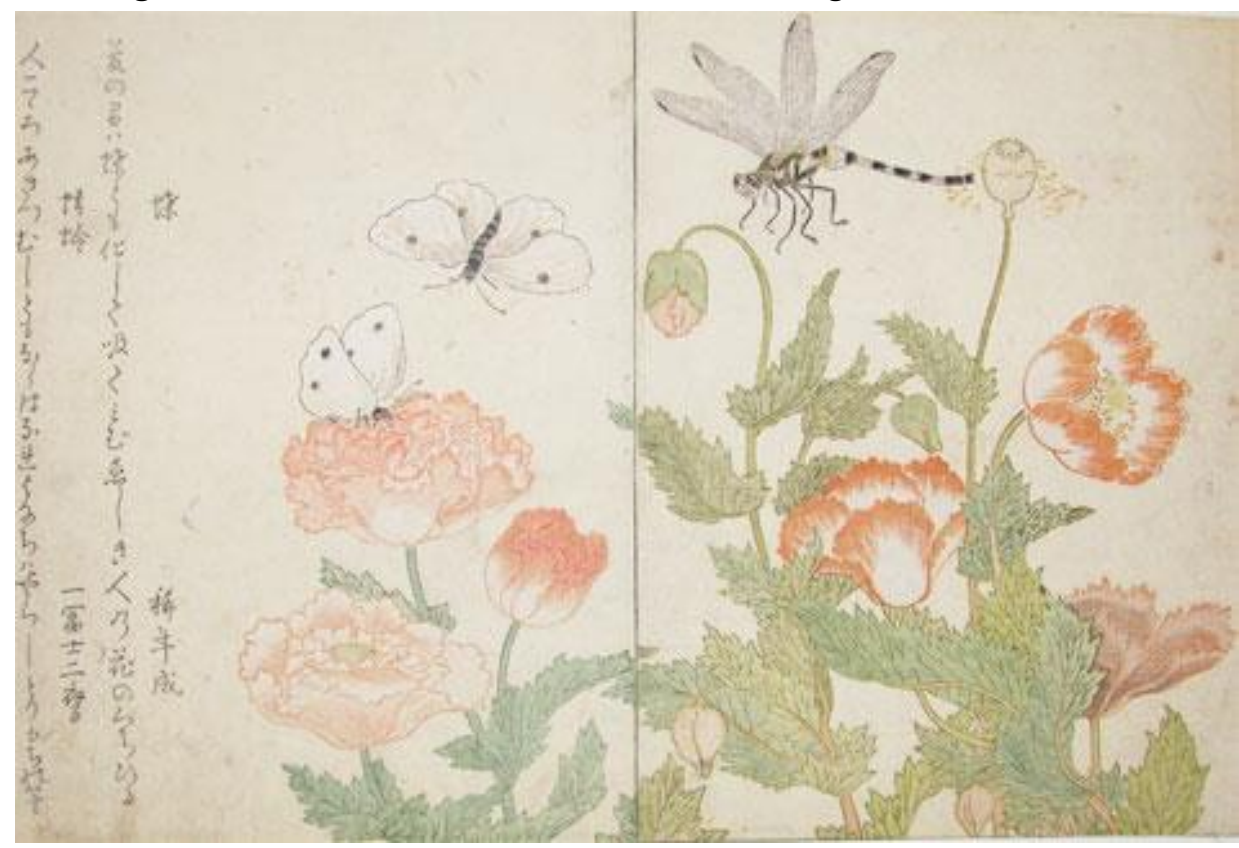

Fonte: http://ukiyo-e.org/image

Figura 114 - Vestido da maison Worth, 1898

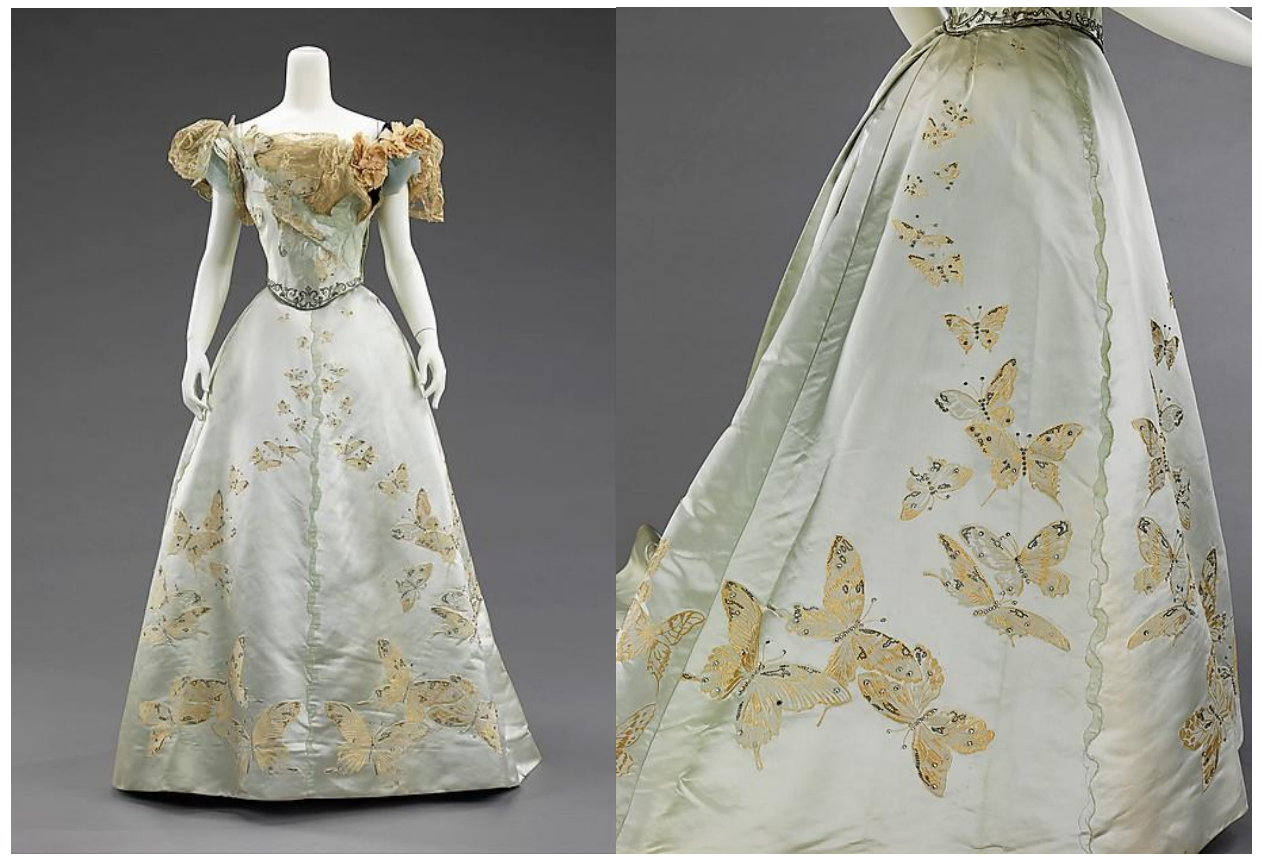

Fonte: http://www.metmuseum.org/collection/the-collection-online/search/156027

Em 1890, é apresentada uma nova e diferenciada estilização de elementos icônicos japoneses, ou seja, a maison Worth utiliza, além das flores de cerejeira, o capacete kabuto dos samurais (Figura 115). Como se pode ver no casaco de Worth (Figura 116), o kabuto é aplicado na posição vertical. 
Figura 115 - Capacete Hoshi Kabuto

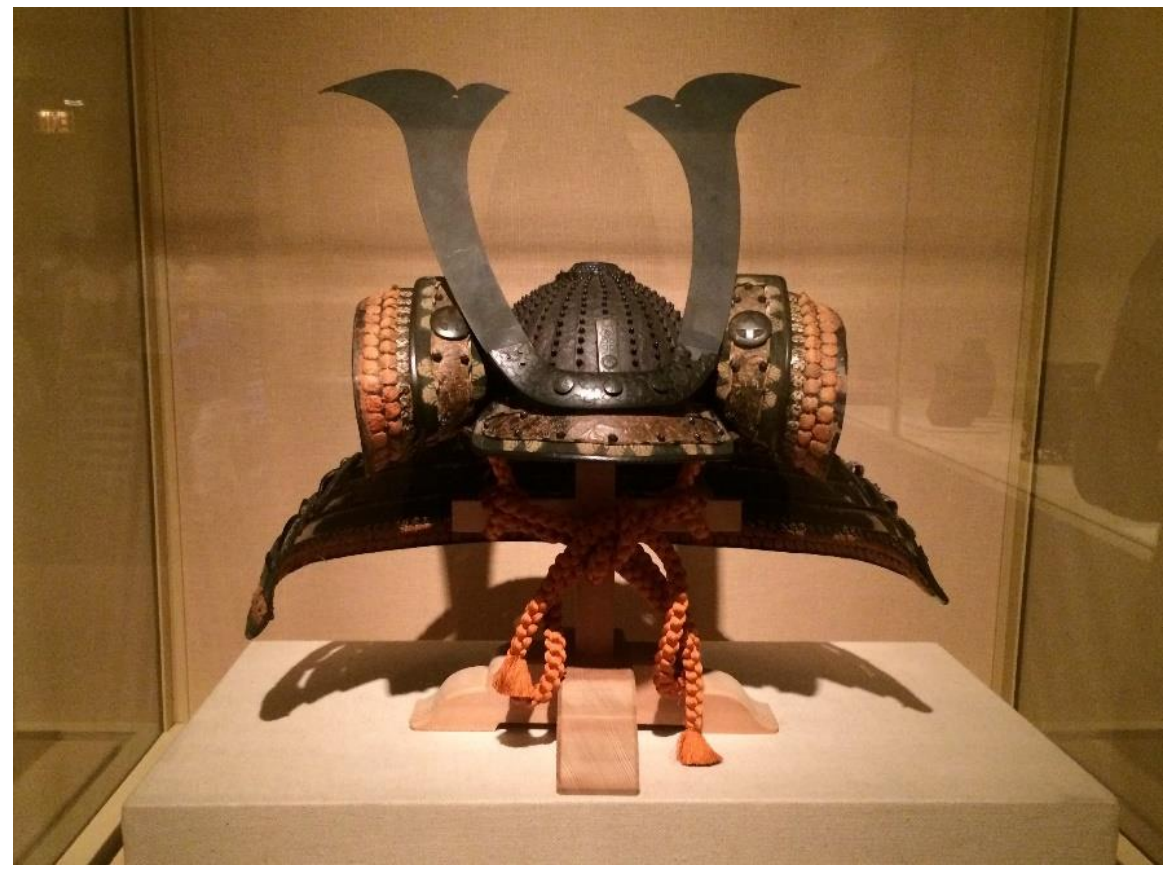

Fonte: Acervo de Luciana Iwamoto

Figura 116 - Casaco de Worth, 1890
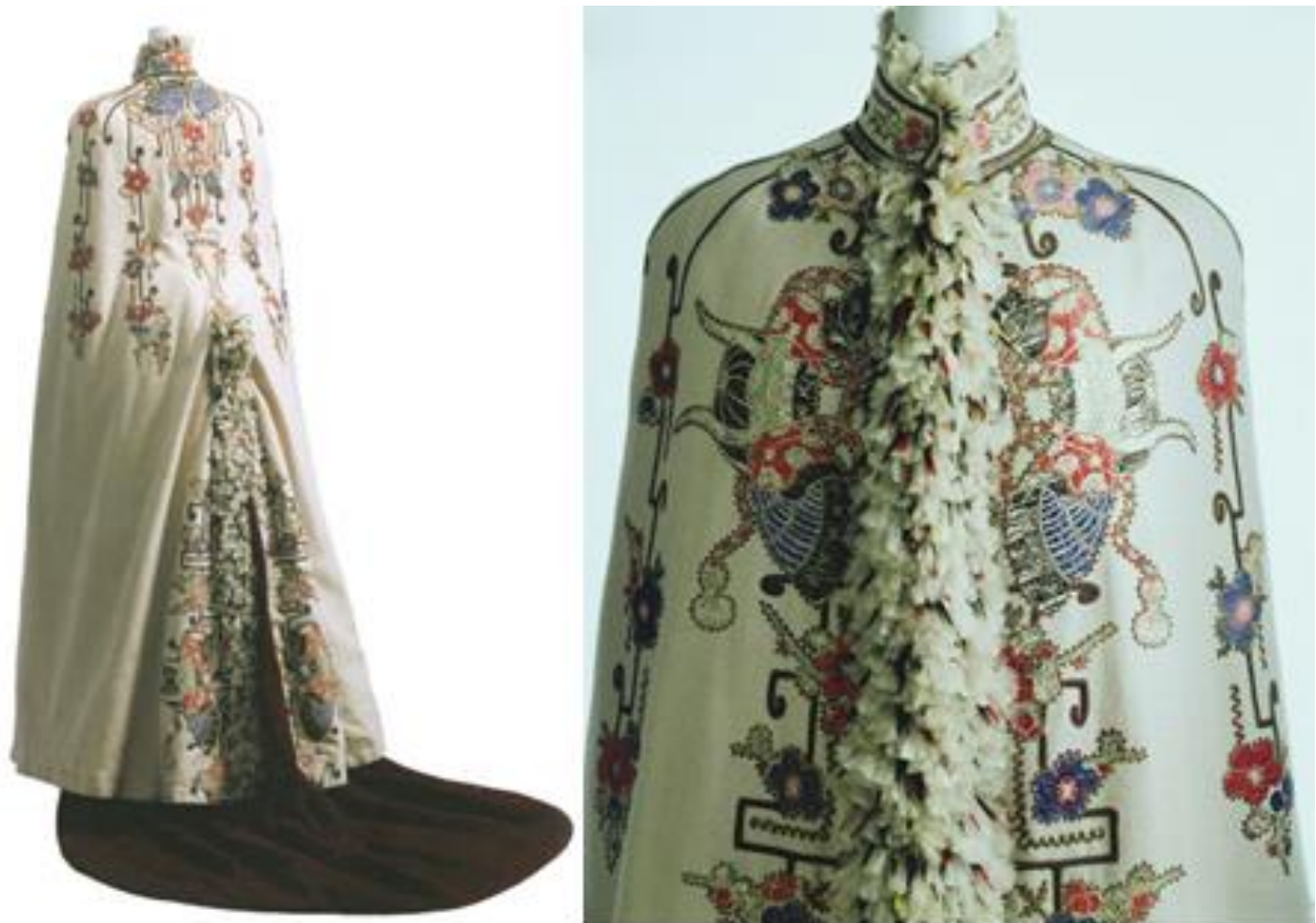

Fonte: http://www.kci.or.jp/archives/digital_archives/detail_98_e.html 
Esse mesmo adorno foi utilizado posteriormente pelo designer britânico Alexander McQueen (1969-2010) em 1996 para Givenchy, representando um exemplo de influência indireta da arte japonesa (Figura 117).

Figura 117 - Capa de McQueen para Givenchy, Paris, 1996
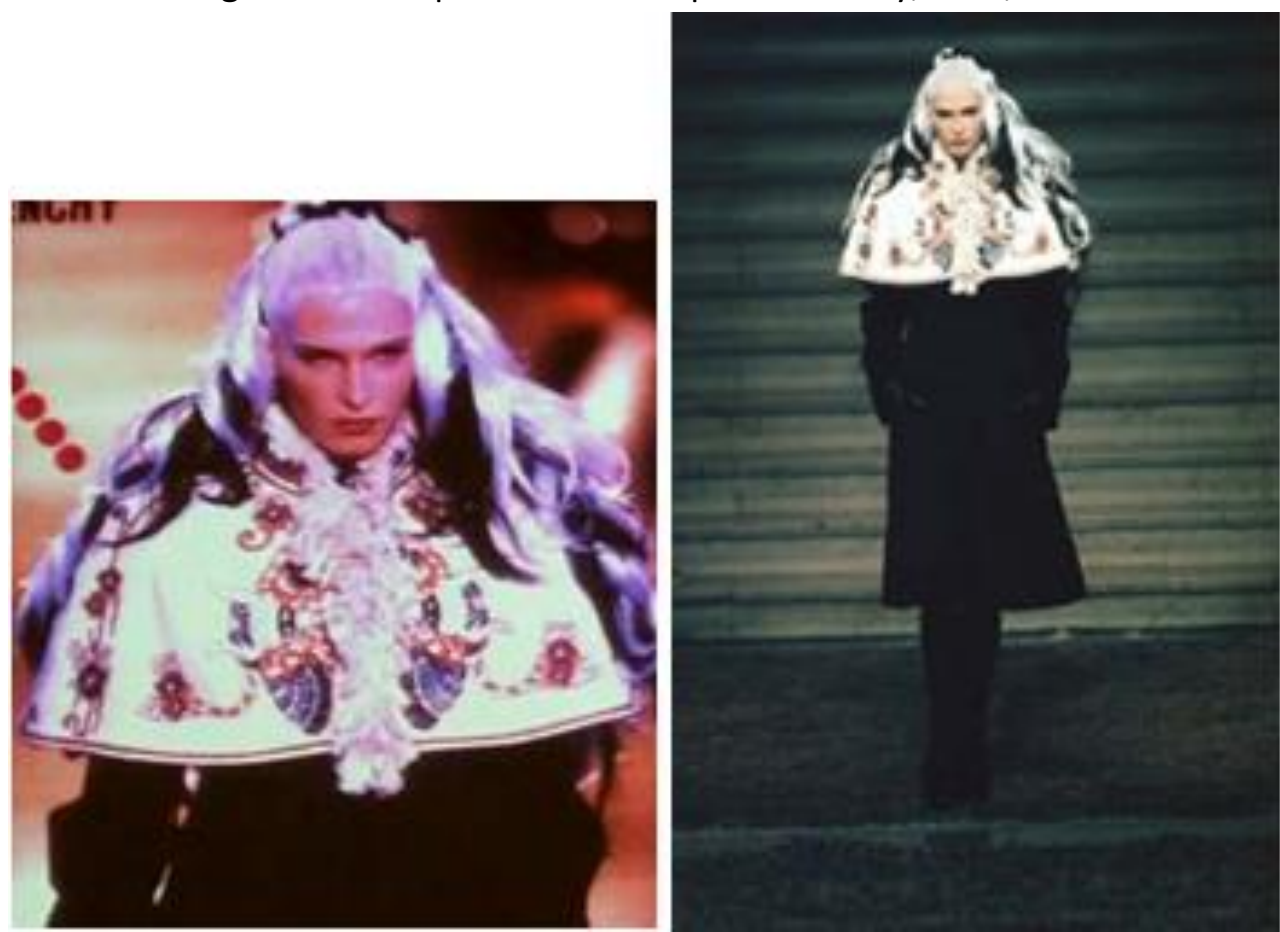

Fonte: http://forums.thefashionspot.com

Indo mais além, a maison Worth emprega um aspecto composicional em sua criação, a assimetria. De acordo com Fukai (1994), o vestido da Figura 118, por exemplo, apesar das mangas bufantes que expõem o estilo ocidental da década de 1890, ele possui ornamentos de raios de sol da manhã, que não só se associam intimamente ao Japão, o "País do Sol Nascente", como também estão posicionados fora do centro, aspecto raro na moda ocidental antes desse período. O resultado é um fascinante exemplo de fertilização cruzada entre as duas culturas. 
Figura 118 - Vestidos da casa Worth, 1895
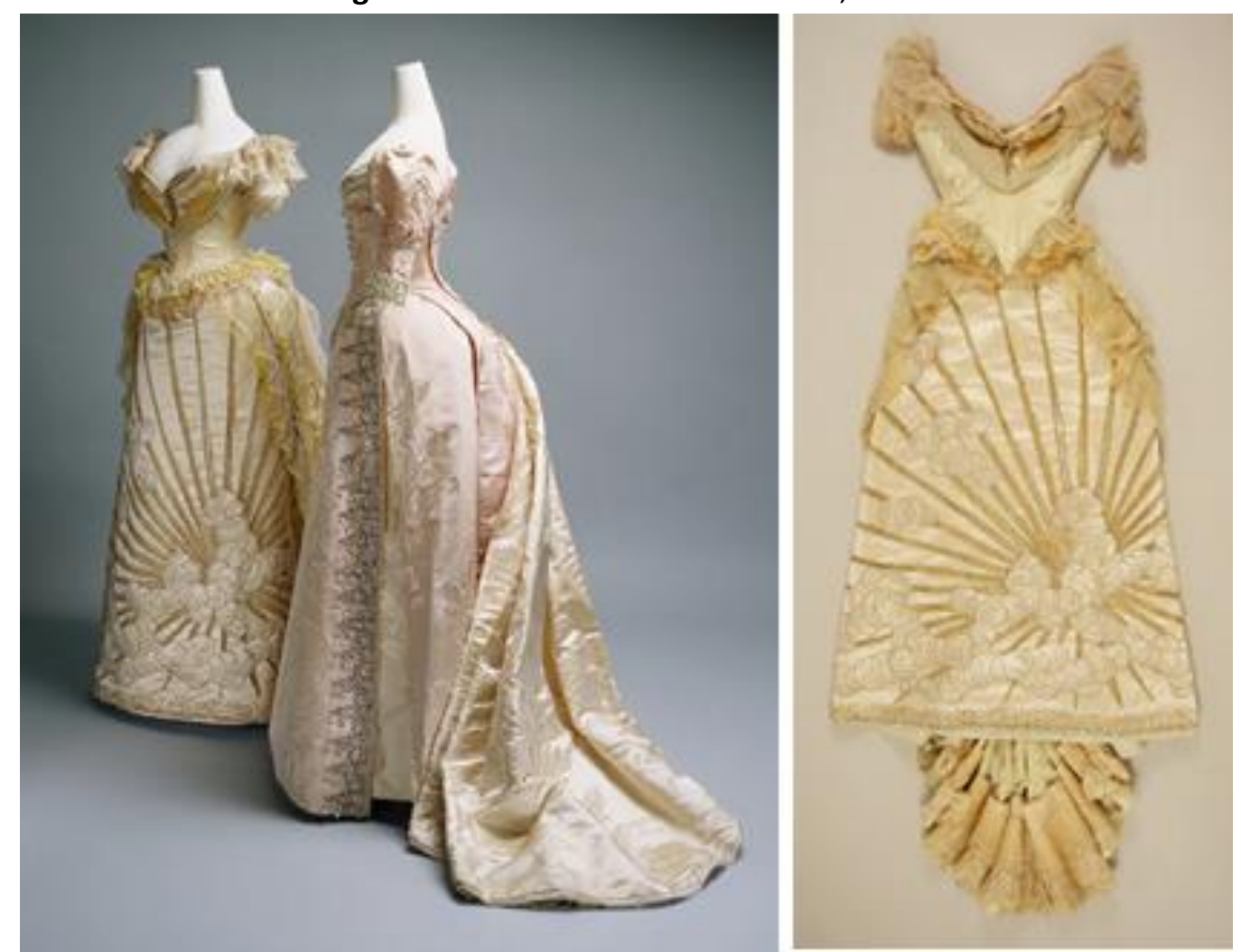

Fonte:

http://www.powerhousemuseum.com/collection/database/?irn=143714\&search=lyon+\&images=\&c $=1 \& s=$

\subsubsection{Os acessórios de moda}

A rápida assimilação de tudo que remetesse ao Japão e ao exotismo que esse país apresenta não excluiu os acessórios femininos. Segundo Simon (1995), no século XIX, os acessórios de moda configuravam-se como indispensáveis na construção da imagem da mulher, longe de serem selecionadas ao acaso. "Tire da Parisiense suas botas de cetim e verniz, seu lenço de seda, suas luvas, seu leque e as milhares de jóias, e você vai ver o que restará: uma mulher" (SIMON, 1995, p. 188)

Fukai (2007) afirma que o par de slippers foi um dos primeiros objetos designado especificamente para o mercado europeu a ser exportado. A ornamentação com motivos de paisagens, nos quais os lados direto e esquerdo são diferentes, mas que se completam, é uma 
característica forte da estética japonesa, assim como o ornamento dos três macacos entalhados em detalhes na bolsa, denominado netsuke.

Figura 119 - Slipper, início do século XX

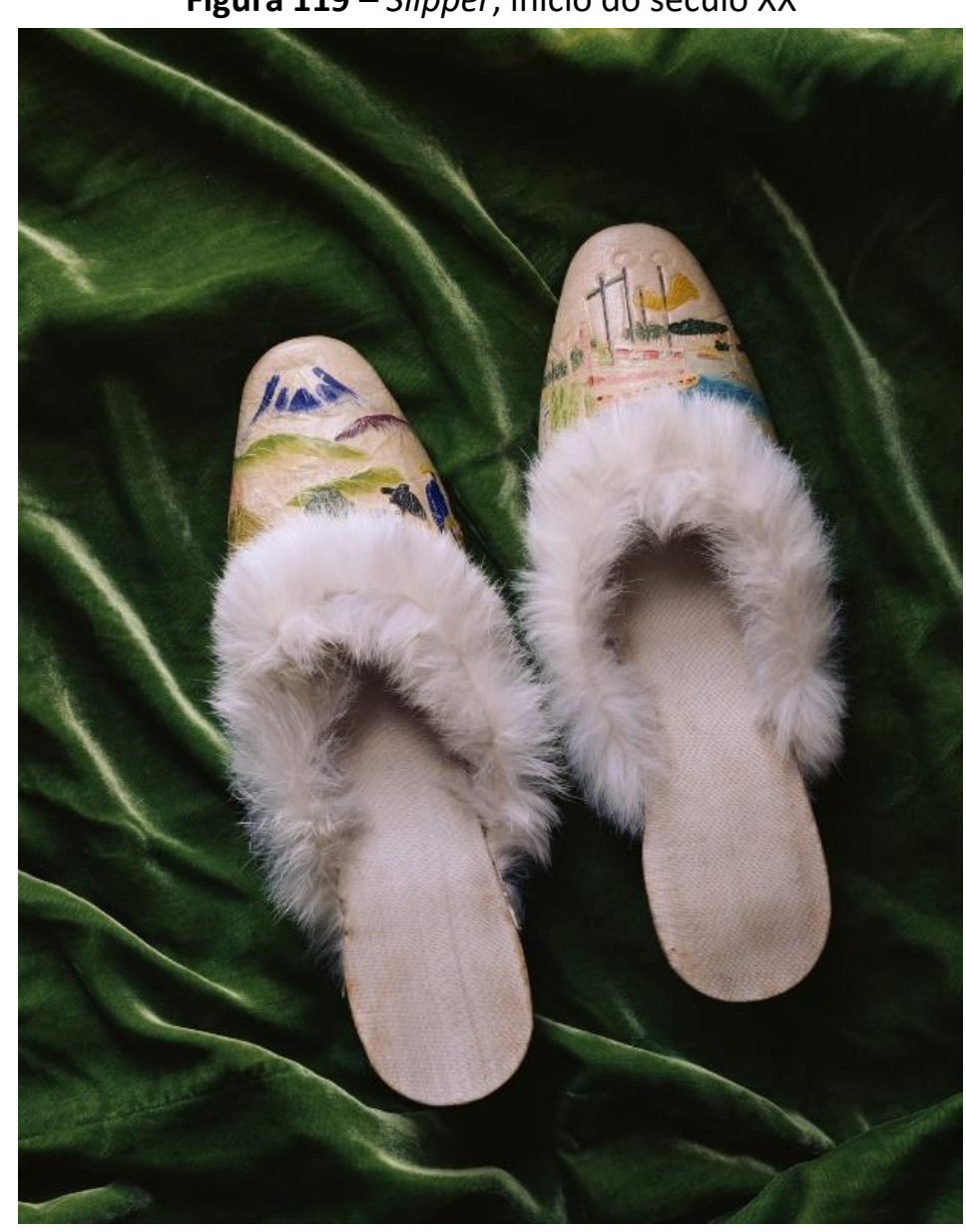

Fonte: Fukai, 2007, p. 270

Figura 120 - Bolsa, início do século XX

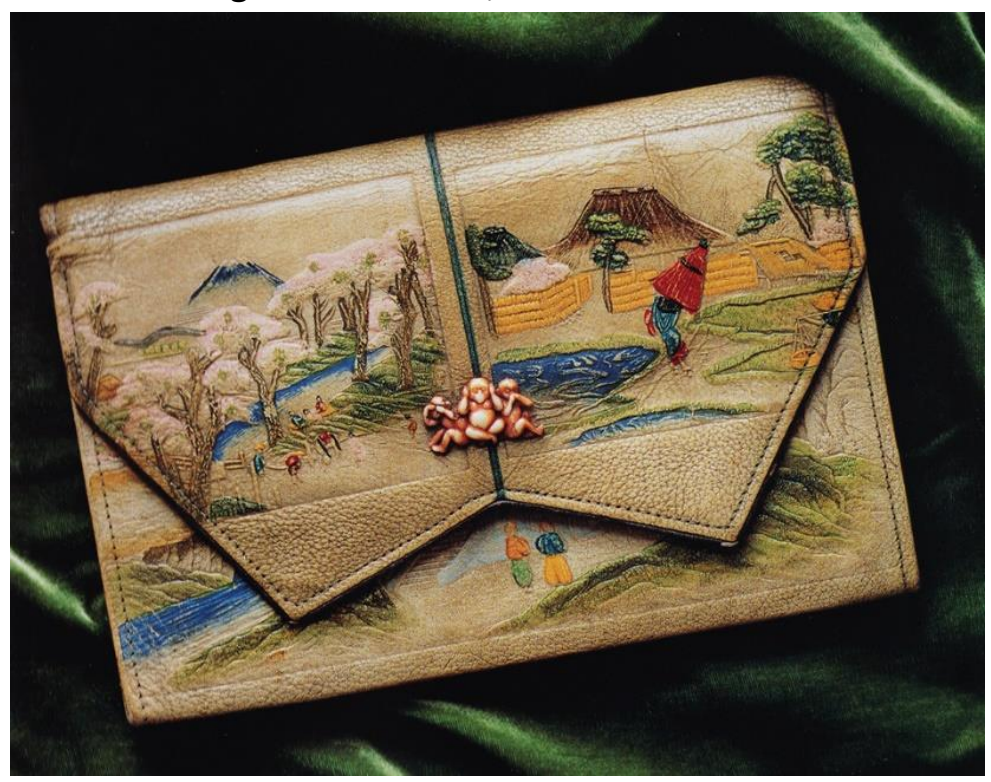

Fonte: Fukai, 2007, p. 271 
Botões de cerâmica também passaram a ser fabricados no Japão. Como a vestimenta japonesa tradicionalmente não possuia fechamento com botões, estes eram direcionados para o mercado ocidental. Devido ao seu brilho incomum, seus ornamentos elaborados e tipicamentes japoneses, alcançaram grande sucesso na Europa e na América na virada do século XX e ficaram conhecidos como Botões Satsuma (FUKAI, 2004).

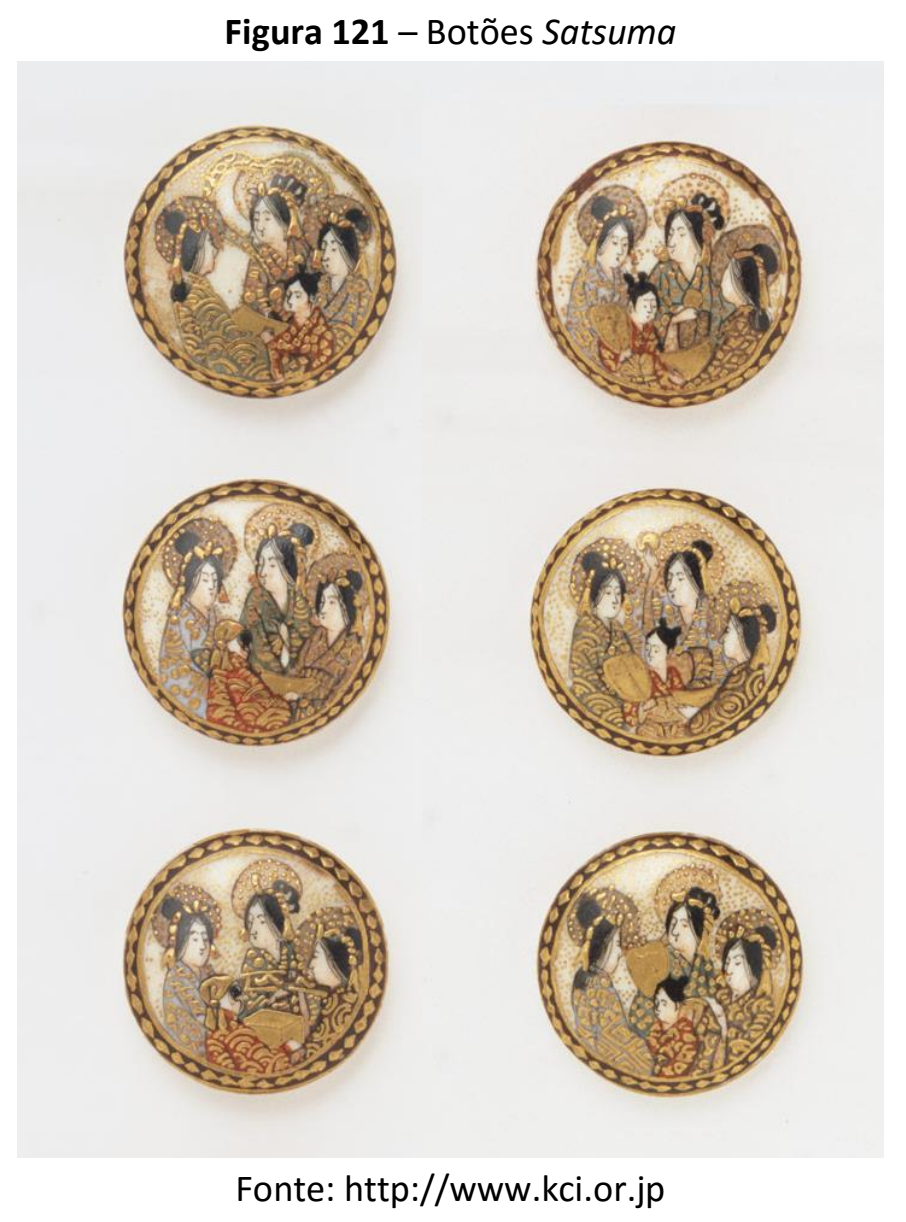

O guarda-sol e o leque, mesmo que já conhecidos e utilizados no Ocidente, adquiriram um novo ânimo e significado após a abertura dos portos japoneses.

Como já mencionado, a pele alva permanecia como sinônimo de juventude e beleza, mas o guarda-sol não era utilizado apenas para este fim. Ele tornou-se um acessório que enfatizava o lazer e a elegância feminina e, assim como o leque, auxiliaria nos flertes, ajudando o público masculino a identificar as intenções femininas (BEAUJOT, 2012). No Japão, o uso 
também era muito popular devido à beleza ser associada à pele branca, conceito que se ecoa até os dias atuais.

No período Edo (1615-1868), o tipo de guarda-sol denominado Wasaga era o mais popular entre as classes mais altas, feitas com estrutura em bambu, papel e óleo. Esse tipo de guarda-sol se popularizou no Ocidente e foi absorvido como reflexo direto do Japonismo (Figura 122) (NIHON, 2015). O guarda-sol destinado à exportação tinha uma designação específica: Komori-gasa; mais elaborado em relação aos produzidos em seu país de origem. Essa tendência se registra na obra de muitos pintores do Impressionismo e esteticismo, que utilizavam o acessório para promover um plano de fundo dramático, exaltando a delicada face da mulher, a exemplificar, a obra de Tissot (Figura 123) (LAMBOURNE, 2005).

Figura 122 - Jovem com um guarda-sol japonês. Pierre Auguste Renoir, 1876

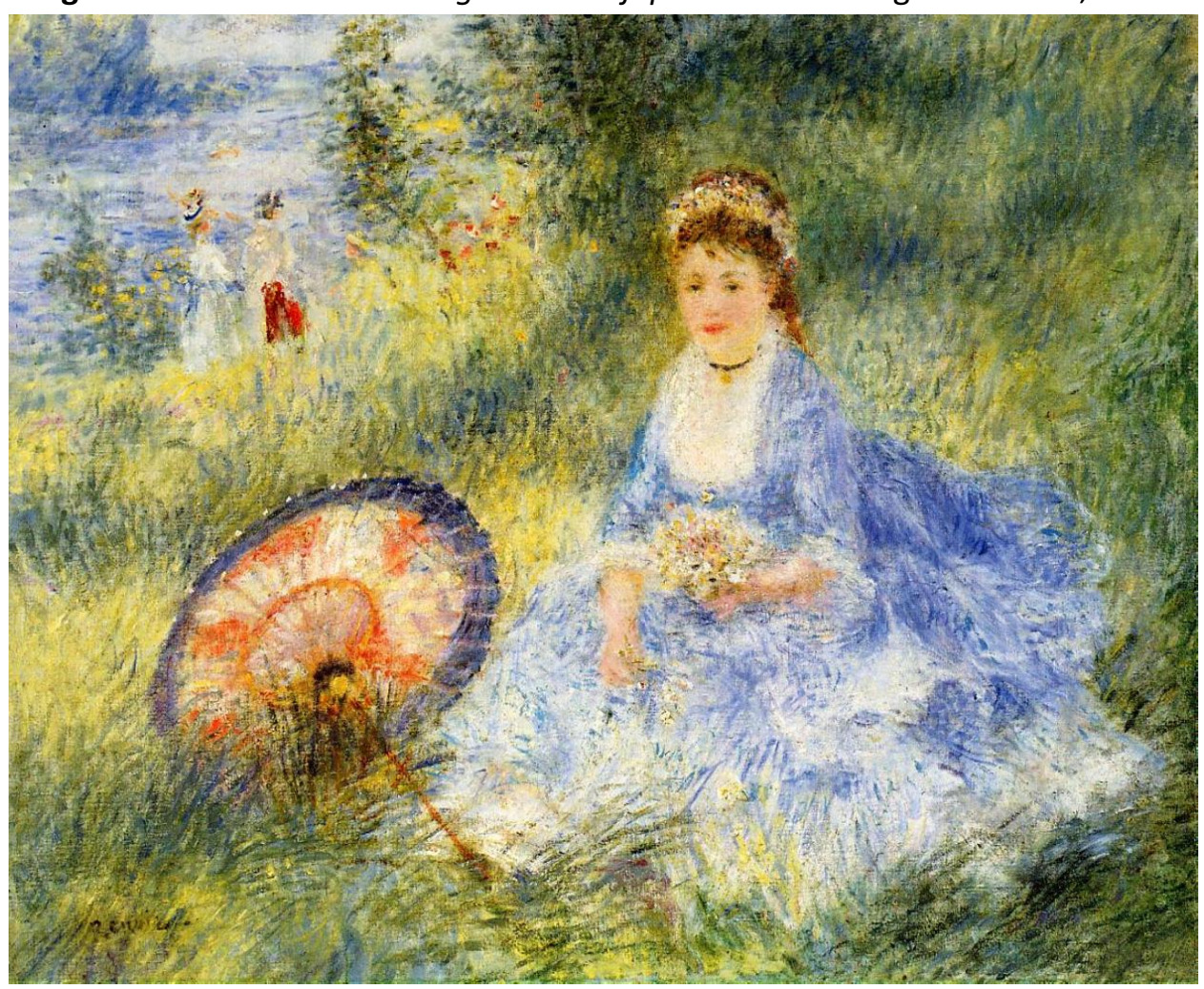

Fonte: http://www.renoirgallery.com 
Figura 123 - Mrs. Newton com um guarda-sol. James Tissot, c. 1879

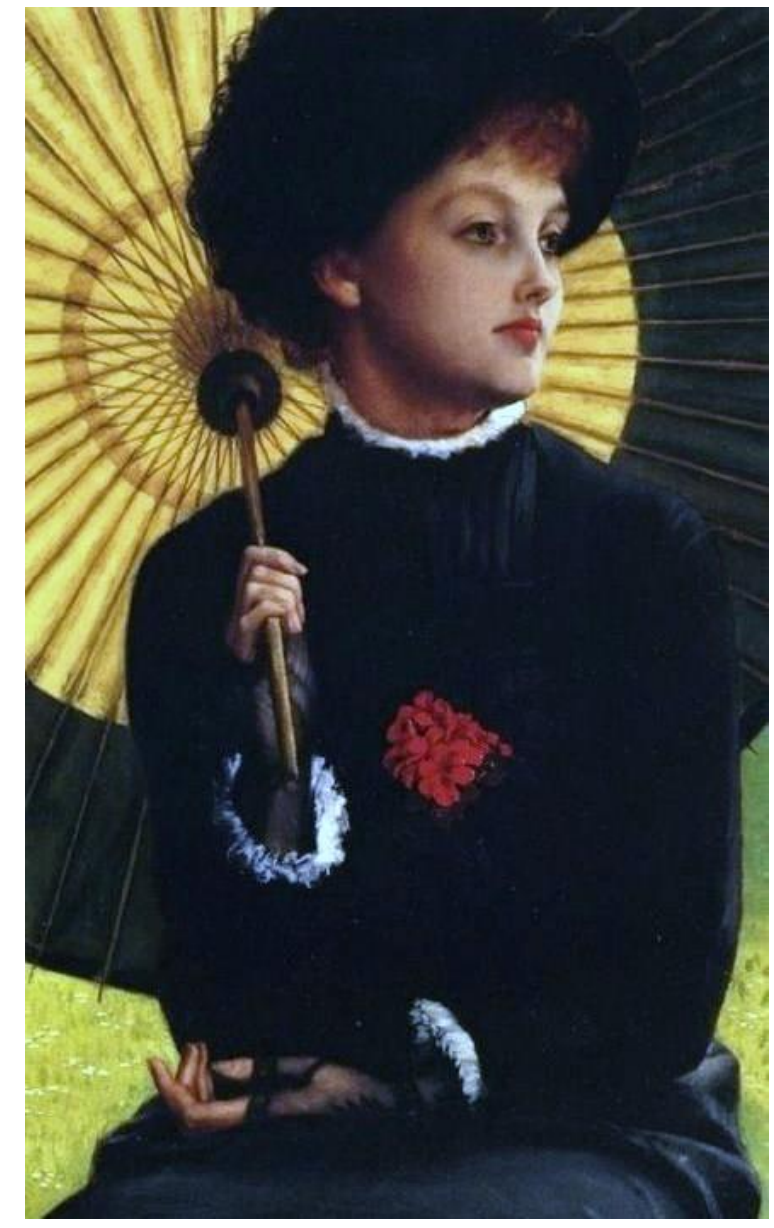

Fonte: www.jamestissot.org

Por evidente, as ilustrações e revistas de moda, por serem midiáticas, exerceram papel importante no aumento de interesse por esses objetos. 
Figura 124 - Ilustração de La Vie Parisienne: "Os guarda-sóis da moda: Japonaiserie de outono". Início do século XX

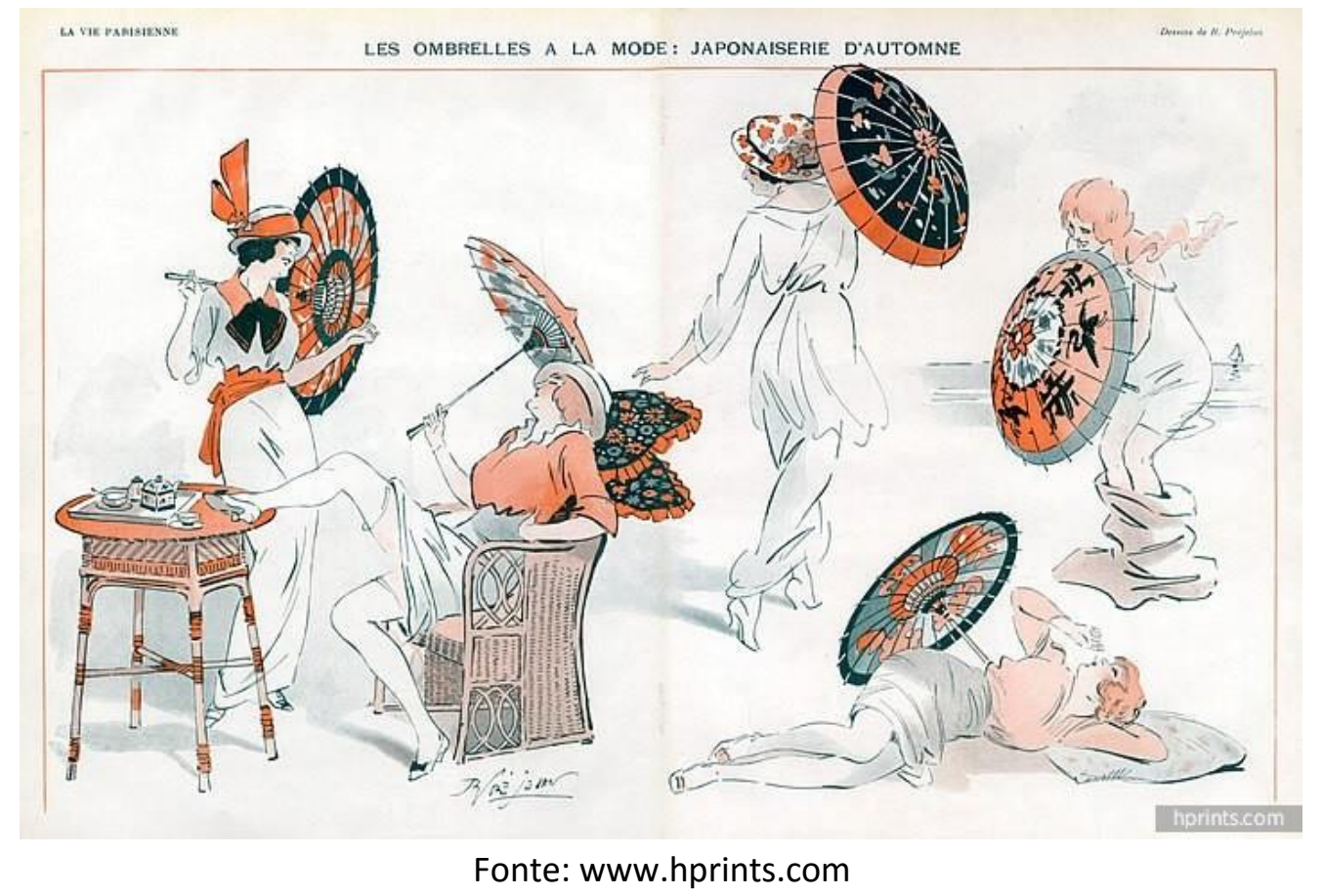

Do ponto de vista histórico, o leque configurou-se como parte integrante do vestuário feminino ocidental desde o século XVII, mantendo-se bastante popular até o século XIX. Assim como a sombrinha, tem a função de proteger, mas sua importância vai além de tornar mais fresco os meses de verão, uma vez que funcionava como adorno. Tcherviakov (1998) acrescenta que, indispensável para a imagem feminina, o leque tinha também capacidade altamente comunicativa, oferecendo uma linguagem não verbal e única. Octave Uzanne (1851-1931), escritor francês, possuía como tema foco a pesquisa e a discussão da moda e da feminilidade francesa do fin-de-siècle. Entre inúmeros títulos, dedicou-se a produzir escritos exclusivamente sobre os acessórios da época, e afirmou em seu livro dedicado aos leques: "Entre as joias da ornamentação feminina, o leque é a prioridade porque, na terra de graça e espírito, ele brilha na primeira fila" (UZANNE, 1884, p.6)

O leque se mostra no presente estudo relevante, porque, talvez mais do que qualquer outro país, é associado intimamente ao Japão. Desde a abertura dos portos, o desejo de se possuir leques provenientes desse país longínquo, artigos desenvolvidos por habilidosos artesãos tornou-se inevitável para a classe alta e principalmente para a classe média, já que o leque se configurava como o objeto japonês mais acessível e, provavelmente, o único que poderia possuir (COOK, 2009). Diferentemente das gravuras ukiyo-e, os leques não eram 
meras reproduções, mas, sim, objetos decorativos complexos e refinados, vistos como verdadeiras obras de arte portáteis.

Alexander e Hutt (1992), ao discorrer sobre a historia do leque japonês, registraram que o crítico da Gazette des beaux-arts, Arthur Baignères, escreveu, em 1880, sobre a "epidemia de leques" que acometia a França que, no auge de sua popularidade, chegaram a ser exportados aos milhões. O total de leques recebidos no ano de 1891 conta em surpreendentes 15724048 unidades, demonstrando a intensa relevância do acessório. Mais que uma "moda", ele se tornara uma verdadeira mania e, expõem o clima de consumo descomedido na França.

Da mesma forma das peças de vestuário, houve a adaptação das técnicas tradicionais japonesas para desenvolver aquilo que se imaginava que o Ocidente desejasse. Alexander e Hutt (1992) afirmam que, de maneira geral, os leques se tornaram mais ornamentados e elaborados, com uma evidente predileção por temas nipônicos óbvios.

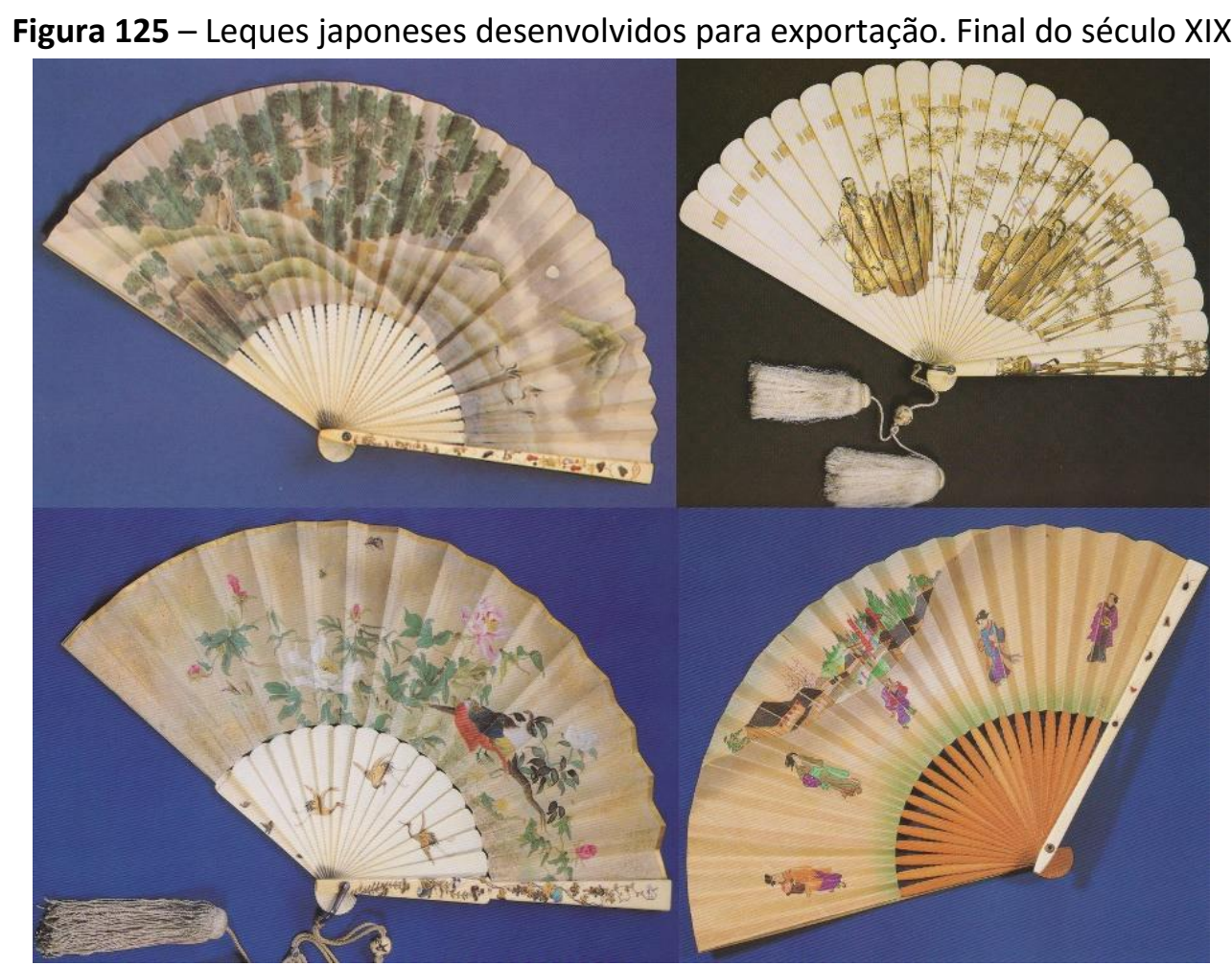

Fonte: Alexander e Hutt, 1992, p. 76

Tamanha demanda logo fez com que o leque se tornasse um objeto produzido em massa. Cook (2009) refere que, devido a isso, essa peça configurou-se como o único item 
relacionado com o Japonismo o qual estava disponível para todas as classes sociais. Entretanto, o uso generalizado do leque não era visto da mesma maneira na sociedade. Desse modo, era possível identificar o status social da mulher pelo seu leque: enquanto a mulher da classe média portava o leque de renda, de penas ou de musselina, as ricas estariam com o legítimo japonês, pintado à mão (Figura 125). As classes mais baixas teriam as opções dos leques de papel estampado e com a imitação produzida na Europa. Nessas circunstâncias, o uso do leque determinava uma classificação social com base em bens adquiridos e exibidos.

Simon (1995) descreve que os pintores da época também reforçaram e documentaram a ubiquidade e a importância dos leques pelas mulheres francesas e europeias em geral, e expressaram a paixão e a tendência por tudo aquilo que se conectava ao Japão.

O vestido, os acessórios, as poses da mulher parisiense ideal auxiliaram toda uma geração de artistas na construção de um espelho de sua realidade sobre as telas. Dessa forma, eles utilizaram simultaneamente a moda e o Japão como expressão de efemeridade e novidade e da vida moderna, pois, segundo Nunn (2000), o uso do leque, seja ele rígido ou dobrável, tornou-se um sinal pontual do "urbano chic".

Figura 126 - Garota com leque. Auguste Renoir, c. 1881

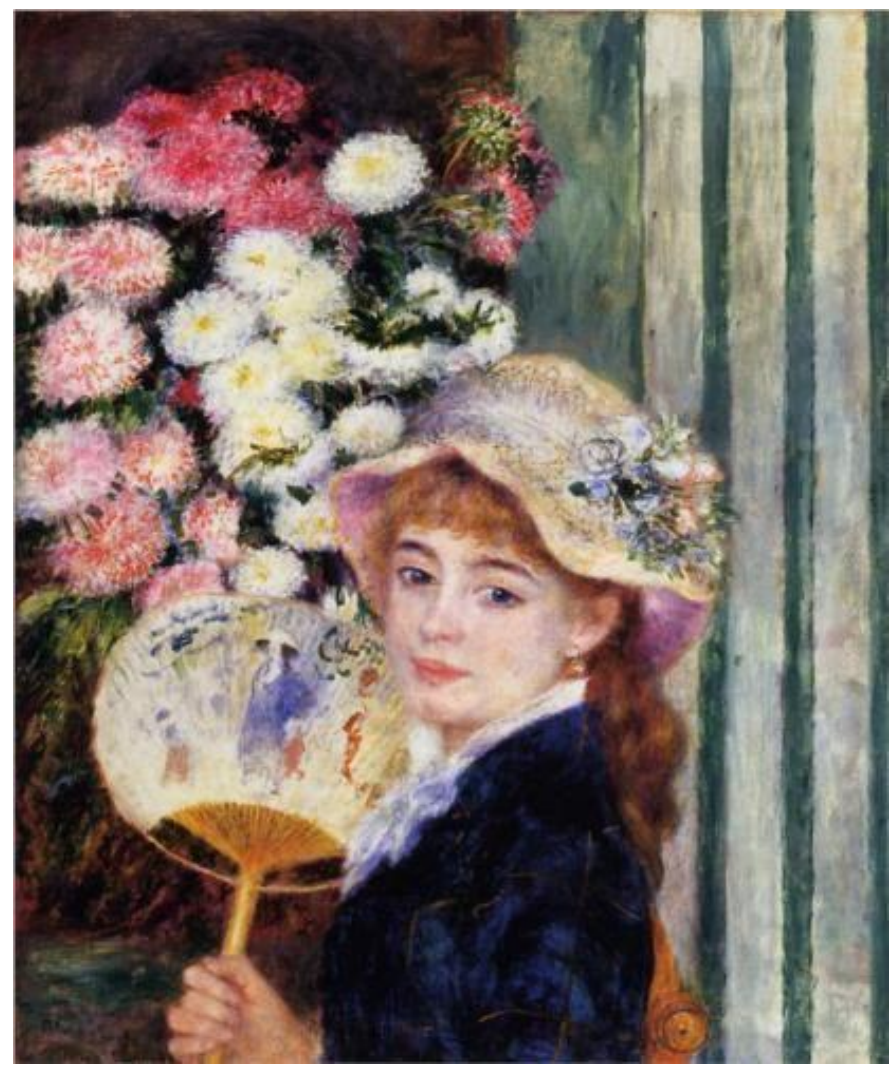

Fonte: http://www.wikiart.org 
Uma vez que a mulher parisiense se tornou sinônimo de contemporaneidade, novos vínculos foram tecidos entre a arte e a moda nesse período. François-Clemente Sommier, mais conhecido como Henry Somm, foi um artista francês que expôs em suas gravuras esse vínculo. Em sua ilustração denominada Japonisme, vinculada na revista Monde Parisien na edição de abril de 1879, há uma mulher segurando uma gravura com uma japonesa vestida em um quimono. Segundo Menon (2005), o descritivo que acompanha essa ilustração adverte que a mulher pode procurar a última moda; porém, será em vão, pois a moda atual é o próprio Japão. Desse modo, ele não só documentou e intensificou a tendência do japonismo, como expôs a conexão entre a mulher parisiense, o Japão e a moda atual.

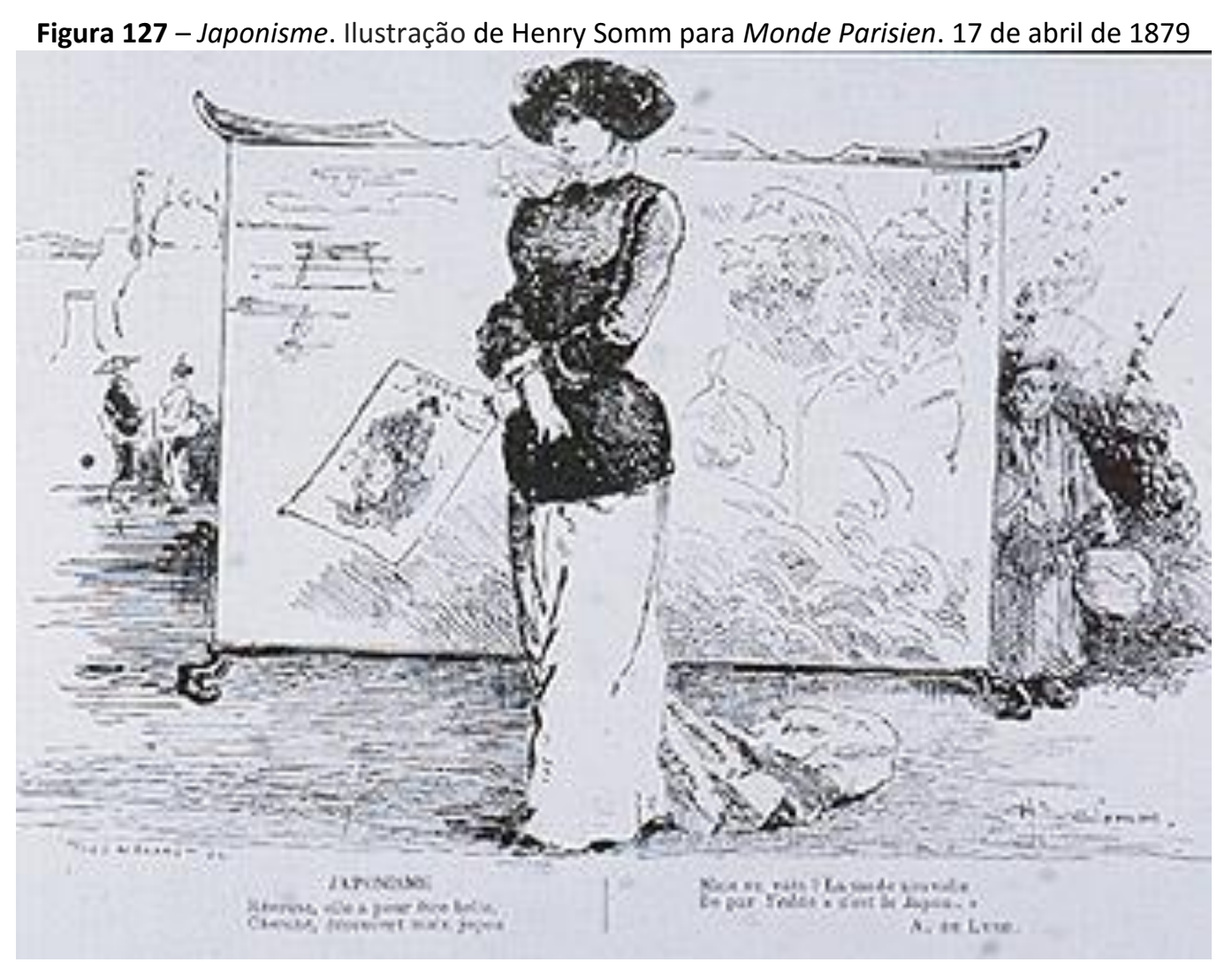

Fonte: http://www.wikiart.org

O leque japonês também foi adaptado para outros usos, sendo ainda utilizado para a decoração de interiores (Figura 128 e Figura 129). Ademais, seu formato semicircular tornouse um aspecto estético e composicional nas mãos de muitos artistas, engajados em explorar as possibilidades que ele oferecia. Degas, um dos mais apaixonados pelo objeto, organiza uma 
galeria no Salon des Indépendants em 1879 em conjunto com outros artistas, dedicado somente à pintura dos leques.

Figura 128 - Mulher com leques, Édouard Manet, 1873

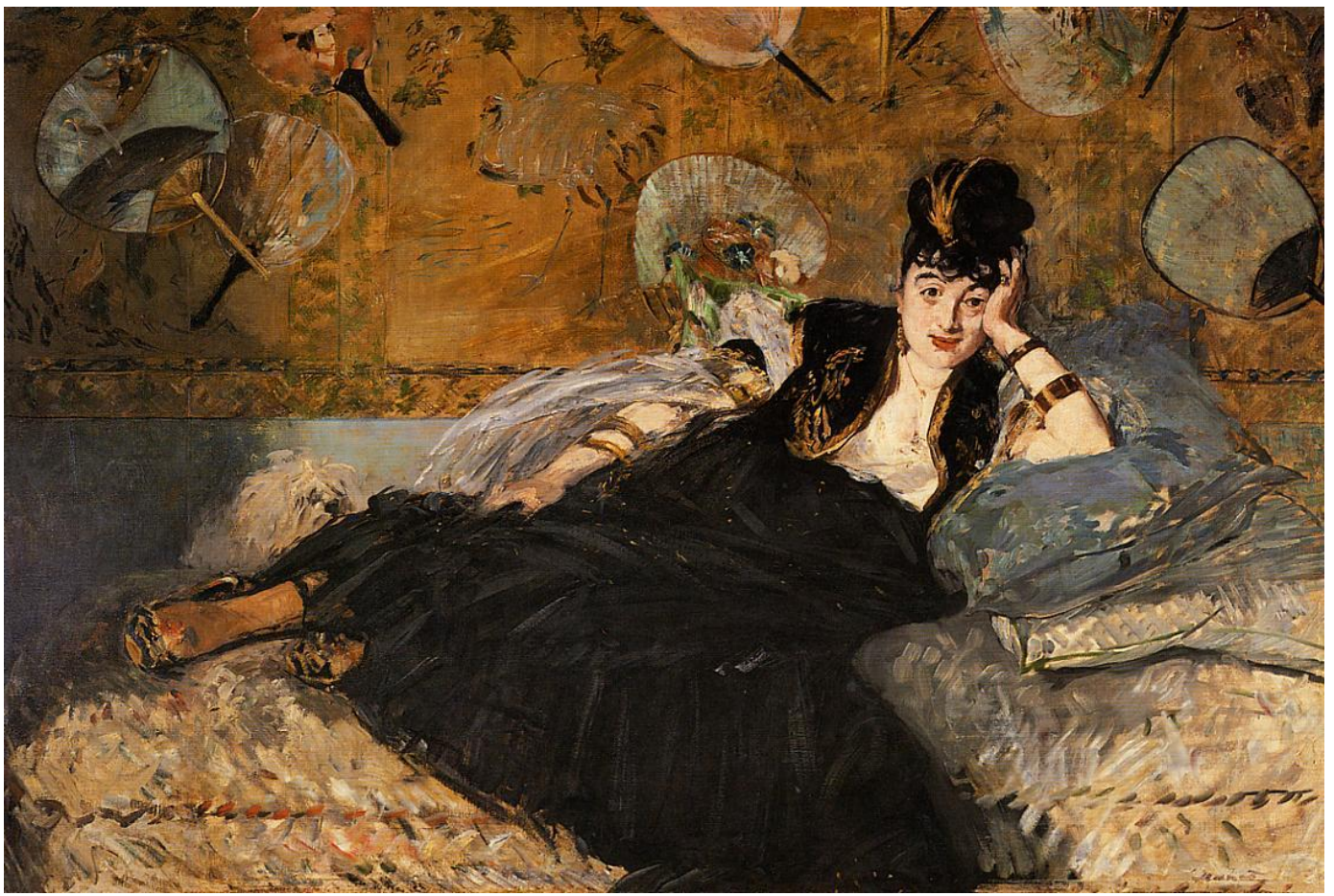

Fonte: http://www.musee-orsay.fr

Figura 129 - Duas irmãs no sofá. Berthe Morisot, 1869

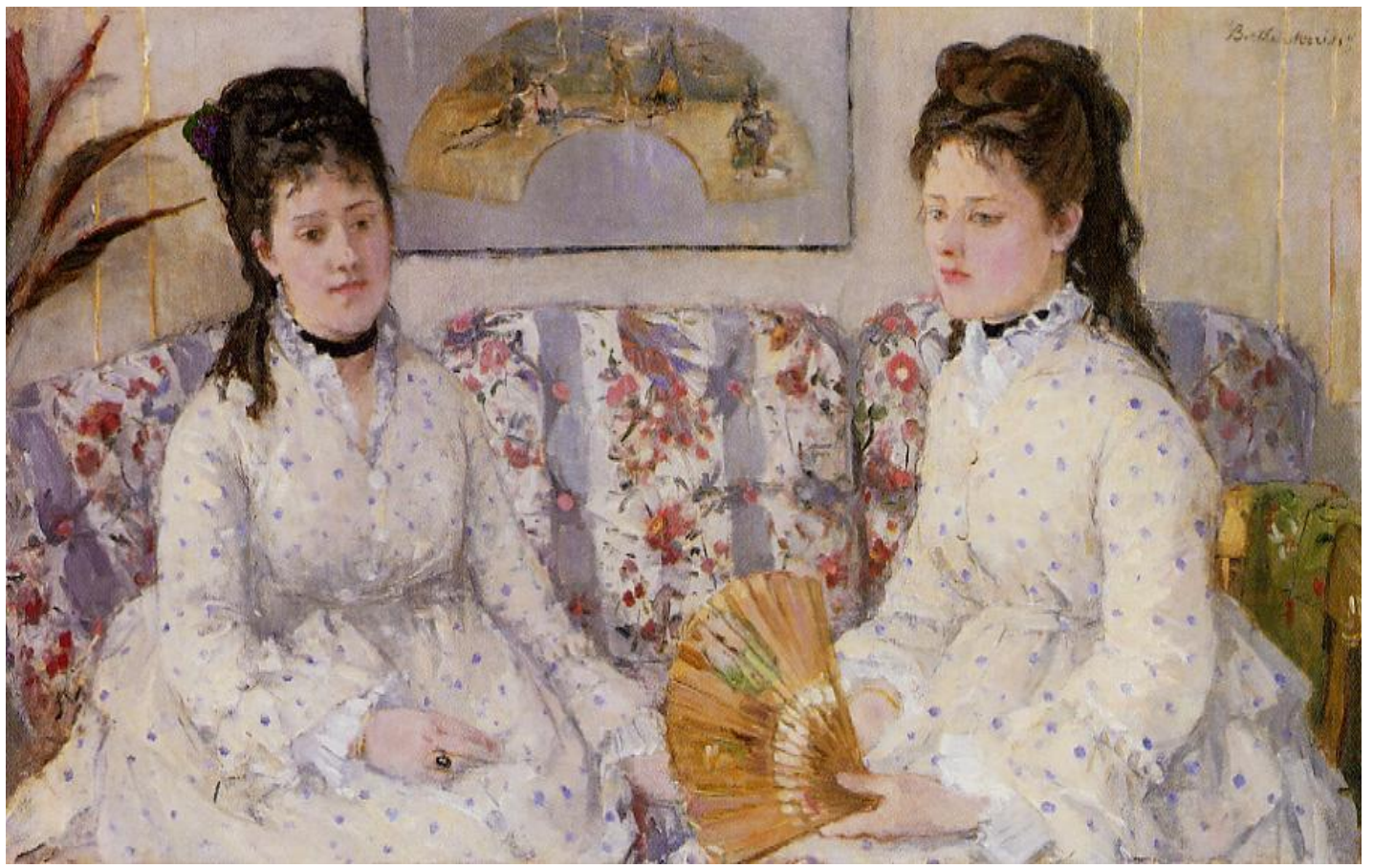

Fonte: http://www.wikiart.org 
Figura 130 - Leques pintados por Edgar Degas, 1879

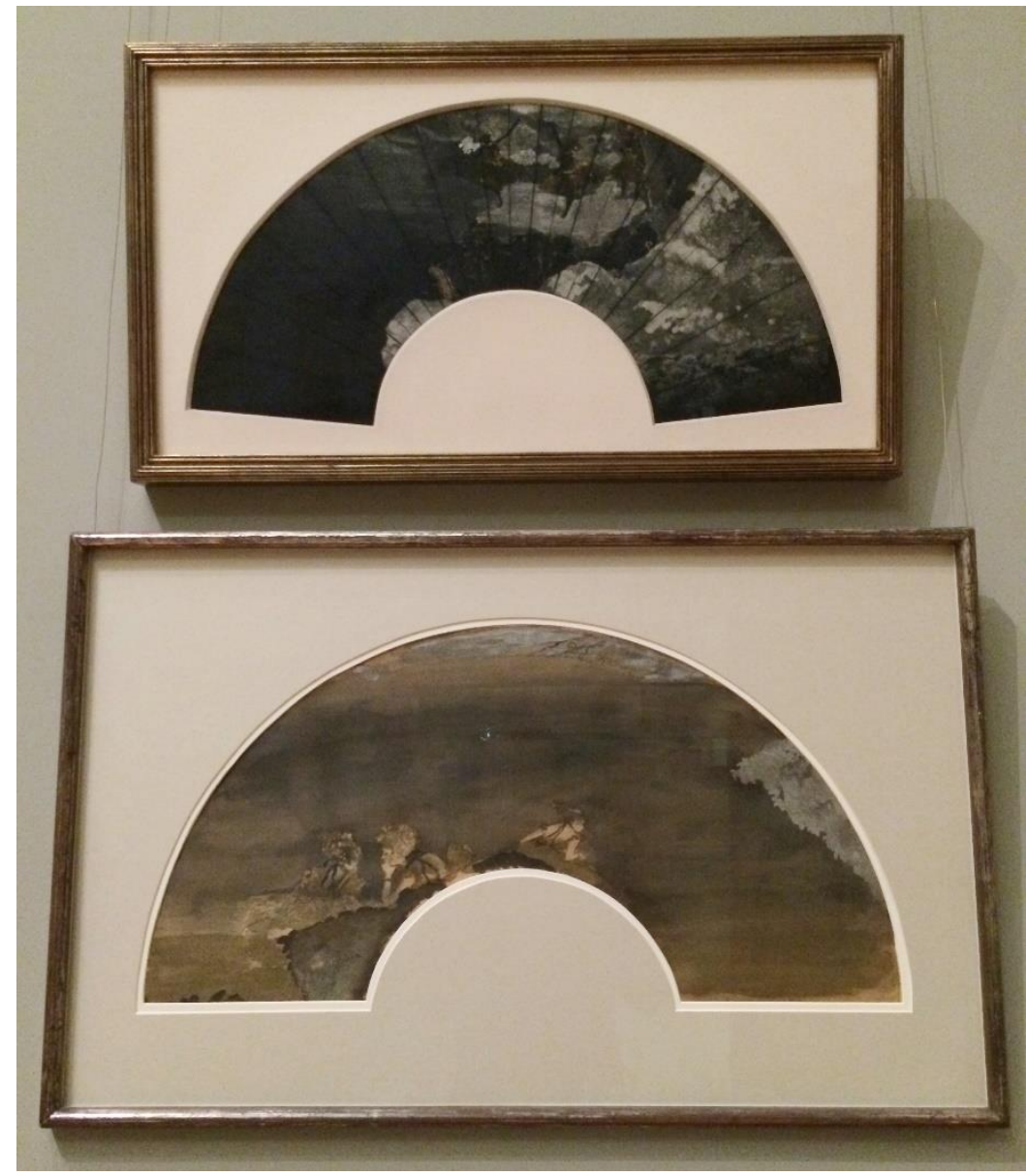

Fonte: Acervo de Luciana Iwamoto

Os acessórios de moda constribuíram de modo significativo no campo da arte. Todavia, no âmbito do vestuário somente emprestaram motivos e adornos do Oriente, como uma consequência natural da "onda japonesa" que se alastrou por todo continente europeu. Assim sendo, o Japonismo na moda até esse momento, apesar de expressivo, não causou mudanças drásticas no pensamento e no sistema vigente, como conclui Lipovetsky:

A moda muda incessantemente, mas nem tudo nela muda. As modificações rápidas dizem respeito sobretudo aos ornamentos e aos acessórios, às sutilezas dos enfeites e das amplitudes, enquanto a estrutura do vestuário e as formas gerais são muito mais estáveis. A mudança de moda atinge antes de tudo os elementos mais superficiais, afeta menos frequentemente o corte de conjunto dos trajes (LIPOVETSKY, 2007, pp. 32 e 33). 


\subsection{Transição do século XX: Paul Poiret e Madeleine Vionnet}

Na transição do século $X X$, percebe-se um novo capítulo do Japonismo no âmbito da moda. Geczy e Karaminas (2013b, p. 116) declaram que o exótico nesse segundo momento não seria visto da mesma forma como anteriormente, mas, sim, como um componente residual e permanente da vida moderna europeia. Em outras palavras, o Japonismo, no contexto da industrialização pré-guerra de 1914, não se fixa mais em sua aura exótica com a apropriação de símbolos representativos - muitas vezes retratado de forma estereotipada mas assimila novos conceitos estruturais e o próprio fazer da alta-costura.

Dois tipos básicos de orientalismo no vestuário definidos por Geczy e Karaminas (2013b) aplicam-se ao fenômeno aqui estudado. O primeiro relaciona-se com a assimilação, a melhoria e a adoção de elementos orientais. Acontece de forma mecânica, prática e oportuna, configurando-se preponderantemente como o Japonismo que se instalou na moda até o fim do século XIX.

O segundo tipo correlaciona-se ao disfarce, ao repatriamento e à re-identificação pelo vestuário regional, nesse caso oriental, definida como estática e arquetípica, possuindo como exemplo o quimono. Nesse segundo momento, no início do século $X X$, o quimono foi empregado por designers revolucionário como um envoltório às suas intenções de escape e alívio da tradição. A inclusão de uma identidade mediante o vestido do "outro" - um "outro" geralmente fascinante ou temido - consegue proporcionar um afrouxamento das restrições sociais (GECZY; KARAMINAS, 2013b).

O vestuário, portanto, passa a ser modificado em sua estrutura, principalmente pela ação de Paul Poiret (1879-1944) e Madeleine Vionnet (1876-1975). Nesta dissertação ambos são privilegiados por terem absorvido os principais discursos artísticos do início do século XIX não como amadores, que se deixam levar pela correnteza, mas por empregarem o Japonismo de forma consciente e estratégica, respaldando suas convicções.

Driesch (2014) defende que os fundamentos teóricos da estética japonesa, que foram destrinchados e absorvidos pelos artistas europeus, emergem nos trabalhos desses designers que buscam estilos lineares, formas simples e cúbicas. Esses conceitos alinham-se aos movimentos artísticos da época, como o fauvista, que possui como características a 
simplificação das formas e as cores intensas, e ao movimento cubista, iniciado por Georges Braque (1822-1963) e Pablo Picasso (1881-1973) e em desenvolvimento nesse período. Segundo Souza (1987, p. 34), sabe-se que a moda, "[...] independente da vida efêmera e dos objetivos mais imediatos, se liga de alguma maneira às correntes estéticas de seu tempo".

Um dos principais aspectos desenvolvido pelos movimentos artísticos, o reducionismo, emerge na moda como um fenômeno de segundo grau, um metafenômeno, de modo que as peças elaboradamente ornamentadas de Worth já estariam, portanto, fadadas à decadência.

Em face de uma sociedade mais ativa, tanto Poiret quanto Vionnet acabam por flertar com novas silhuetas, desvinculadas do convencional espartilho e das volumosas saias, substituindo por estruturas funcionais que ecoam o espírito do modernismo e preconizam a necessidade de roupas simplificadas e fluidas, sem restrição de movimento. A intervenção do Oriente, nesse contexto, auxilia nesse processo de libertação do corpo e abre um novo leque de possibilidades, com criações no qual a ênfase deixaria de ser depositada na cintura para, como o quimono, ser fixada aos ombros, que sustentam a roupa (FUKAI, 1994).

Essa transição do vestuário já se encaminhava no século anterior. George Seurat (1859-1891), em 1888, finaliza sua obra Les Poseuses (Figura 131), que expõe claramente o contraste do corpo vestido e do corpo nu. Segundo Fukai (1994), Seurat representa a moda como criadora de uma silhueta totalmente artificial através de diversos recursos, bem distante da forma natural do corpo. Na virada do século, Gustav Klimt, já citado, sua companheira, Emilie Flöge (1874-1952) e Henry van de Velde (1863-1957) despontaram no mundo na moda propondo vestuários inovadores, um "vestido de Arte" que libertasse as mulheres do espartilho e da silhueta restritiva, com claras referências a culturas distantes, sobretudo no Japão e na África. Fonseca (2010) diz que esse movimento ficou conhecido como Reforma do Vestuário (FONSECA, 2010). Outras iniciativas surgem nos Estados Unidos, como, por exemplo, o traje amplo defenddo por um grupo de feministas conhecido como Bloomer, que também possuiu raízes em culturas estrangeiras. 
Figura 131 - Les Poseuses. Georges Seurat, 1886-1888

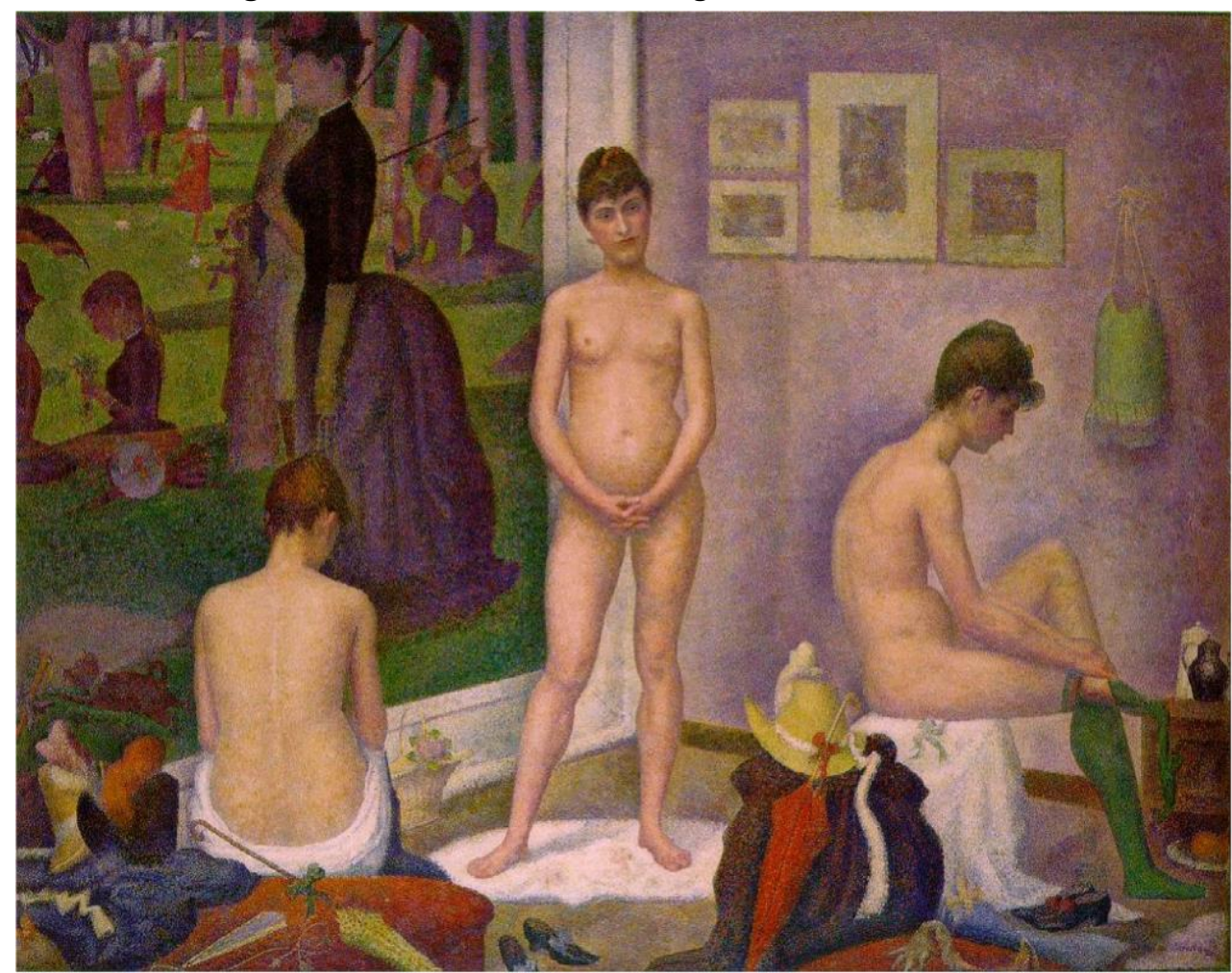

Fonte: http://www.barnesfoundation.org

Todas essas ações contra o corpo aprisionado e artificial, porém, somente teve amplo impacto com a aparição de Paul Poiret no cenário de moda parisiense. Conhecido como "The King of Fashion" nos Estados Unidos e, simplesmente, como "Le Magnifique" em Paris, mais do que qualquer outro couturier de seu tempo, absorveu as influências dominantes do início do século $X X$, especialmente o orientalismo, o primitivismo e o neoclassicismo, dominando o ramo da alta-costura na primeira década do século (KODA; BOLTON, 2007). Com muita frequência, ele visitava museus, exibições de arte e escolas antes de introduzir novos componentes em suas coleções. Apaixonado por pintura, a esse ofício entrega-se posteriormente. Ele teria dito: "Eu sempre gostei de pintores. Parece-me que estamos no mesmo ramo e que são meus colegas" (TIROCCHI; TIROCCHI, 2011)

Poiret trabalhou em conjunto com Jacques Doucet, um dos mais proeminentes designers de Paris do seu período. Como já abordado, Doucet também foi tomado pela onda japonesa ao empregar motivos tipicamente orientais em suas coleções.

Em 1901, Poiret une-se à célebre Maison Worth, onde vem a desenvolver seu famoso e controverso casaco de lã construído a partir de formas simples e linhas retas, batizado de 
casaco Confucius, também conhecido como casaco quimono ou casulo. Esse casaco era dotado de extrema relevância pois ofereceu um novo conceito estrutural emprestado do vestuário japonês (FUKAI, 2004).

Aos olhos de sua cliente, a princesa russa Leonilla Bariatinsky (1816-1918), esse casaco se mostrou simples demais e pouco ostentativo, de modo que foi comparado a um "saco". Sua rejeição, contudo, o induziu a projetar seu nome com essa peça, estabelecendo sua própria Maison em 1903.

Figura 132 - Casaco quimono. Paul Poiret, 1903

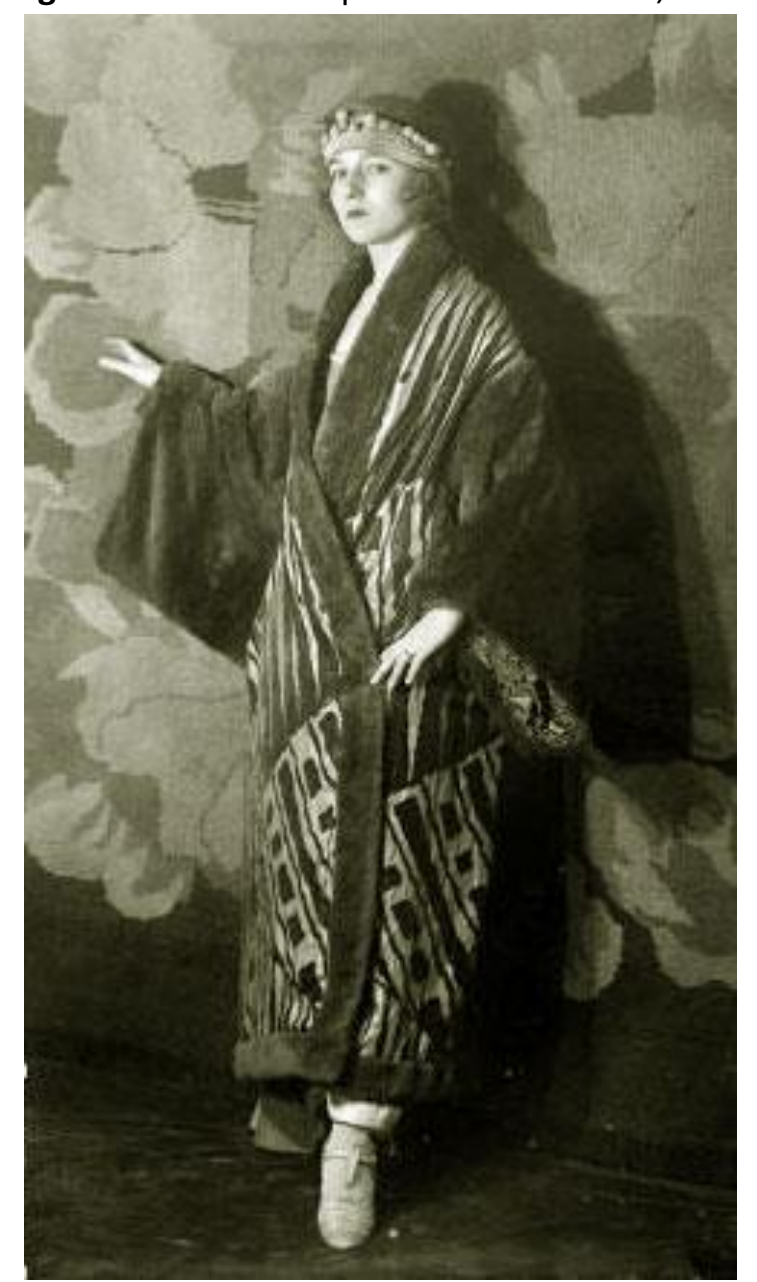

Fonte: http://glamourdaze.com/history-of-womens-fashion

Segundo Koda e Bolton (2007), após aprender a técnica com duas das mais antigas e reverenciadas casas de alta-costura, Poiret pôde prosseguir não só rompendo convenções estabelecidas como também subvertendo e, eventualmente destruindo, presunções adjacentes. Ao transportar a ênfase na planicidade e na abstração bidimensional observados 
principalmente no Oriente, ele abdica a prática tradicional de alfaiataria e rompe com suas tradições (DRIESCH, 2014). Ao apresentar uma nova silhueta, solta e em excessos, ele liberta as mulheres das anáguas e do espartilho que persistiam desde a Renascença quase sem interrupções, e passa a oferecer uma forma corpórea integrada e inteligível. Mesmo que suas intenções estivessem mais enraizadas na estética do que em uma ideologia libertária propriamente dita, corpo feminino, por intermédio de suas criações, não mais seria visto como duas massas divisadas pela estreita cintura, mas, sim, como um cilindro, no qual o tecido deveria envolver, ao invés de prender.

Desse modo, o casaco com referências ao quimono torna-se sua marca registrada, reformulado e desenvolvido plenamente ao longo de sua carreira.

No Metropolitan Museum of Art (2015), é possível observar que as primeiras criações possuíam linhas verticais exageradas, moldes retangulares e minimização do corte dos tecidos para, justamente, enfatizar a silhueta livre do espartilho.

Figura 133 - Casaco por Paul Poiret, c. 1912

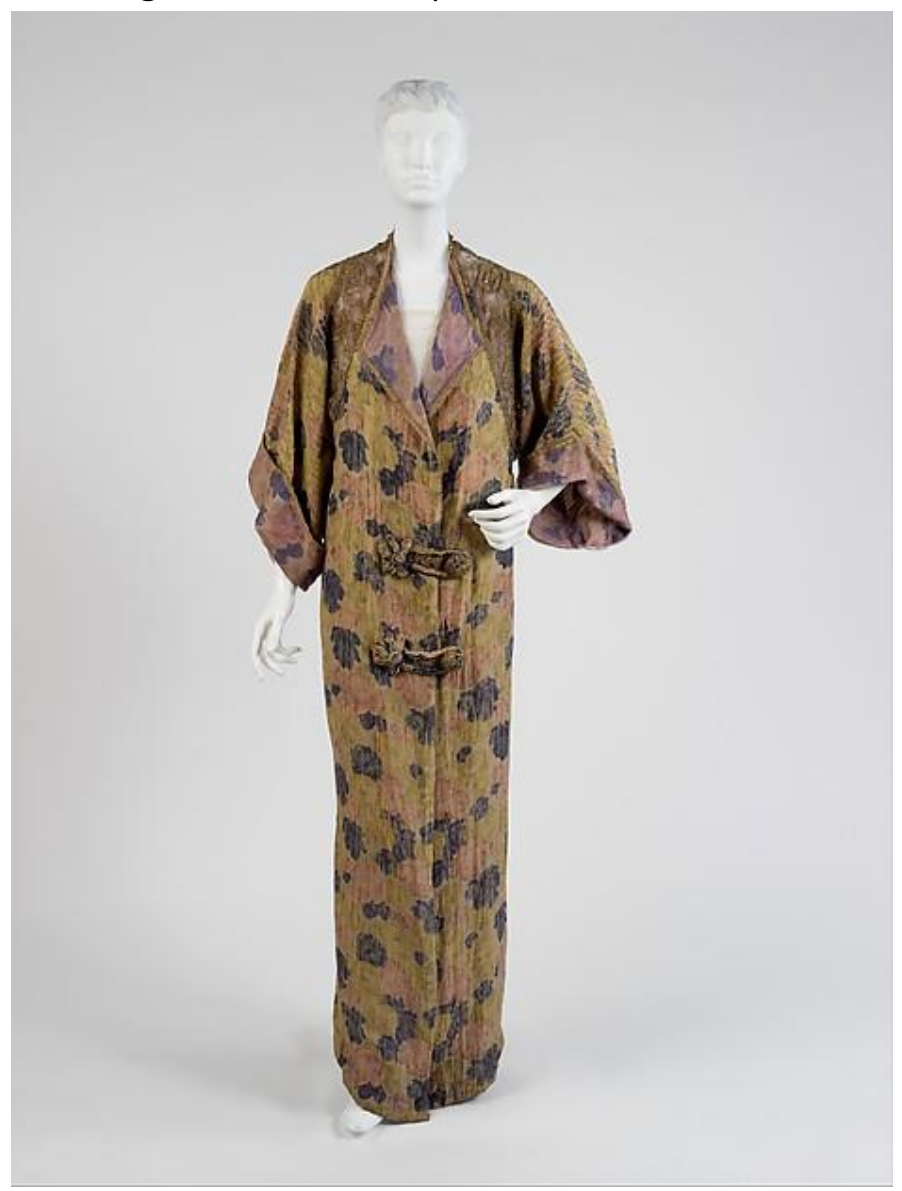

Fonte: www.metmuseum.com 
O orientalismo de Poiret traduziu-se também pelo uso da cor, configurando-se como uma grande inovação. Koda e Bolton (2007) afirmam que Poiret rejeita as paletas suaves da moda anterior e lança-se às cores fortes e expressivas como o vermelho, o amarelo, o verde e o azul. Em seu livro de memórias, Poiret registra sua desaprovação da paleta de cores dos séculos anteriores, chamando-a de esmaecida, desbotada e insípida. Apesar de as cores fortes estarem disponíveis desde a metade do século XIX devido à introdução da anilina, elas configuram-se como reflexo do Japonismo, seja de modo direto ou indireto, pois é anterior à chegada e à fixação do Balé Russo em Paris, em 1909, outra inspiração de Poiret.

Na seleção abaixo, percebe-se a manifestação do Japonismo não só na silhueta simplificada, com economia de cortes, mas também nas configurações cromáticas intensas, em combinações audaciosas.

Figura 134 - Casaco por Paul Poiret, 1910

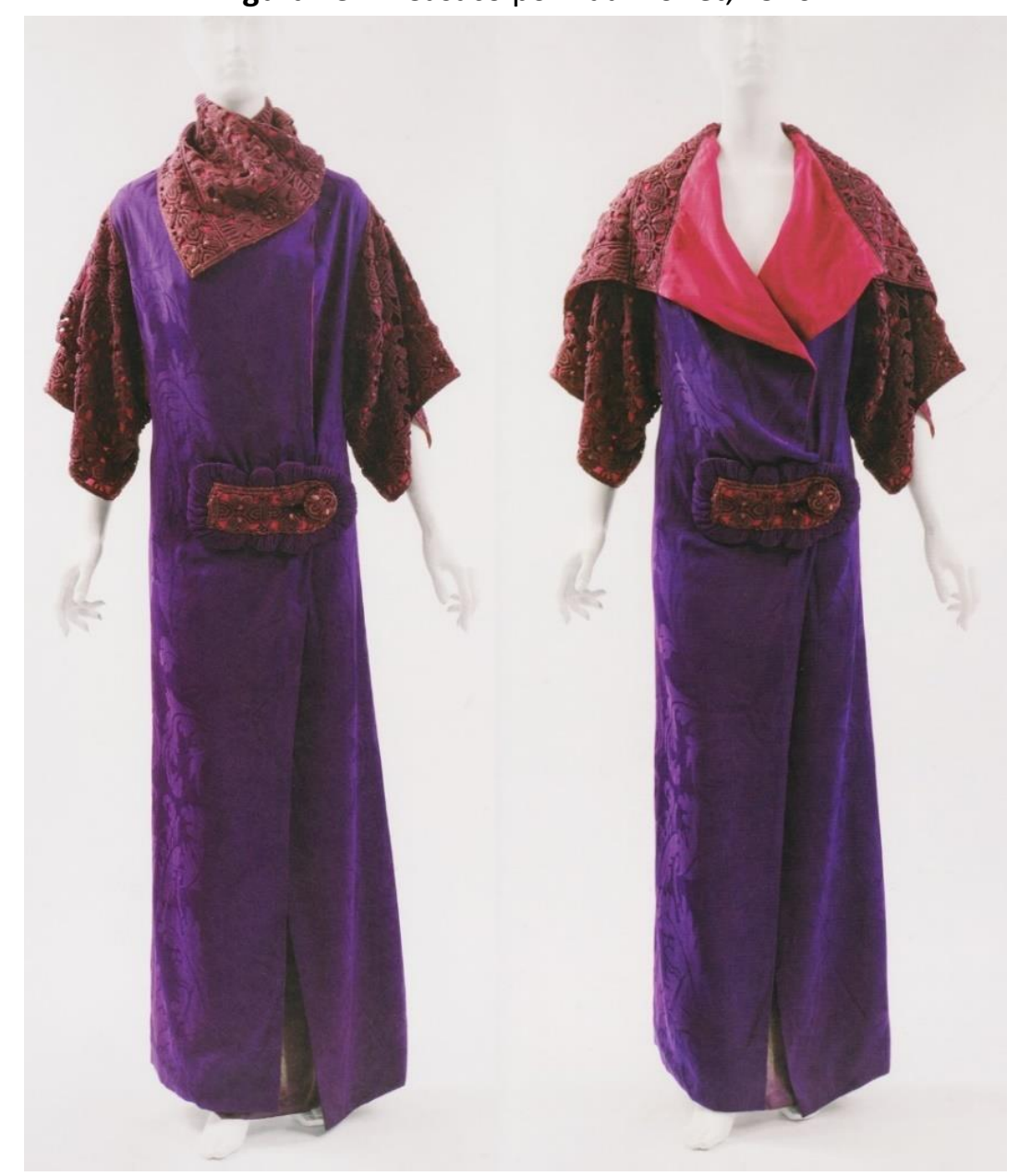

Fonte: Koda e Bolton, 2007, pp. 60 e 61 
Figura 135 - Evening Coat, Paul Poiret, c. 1912

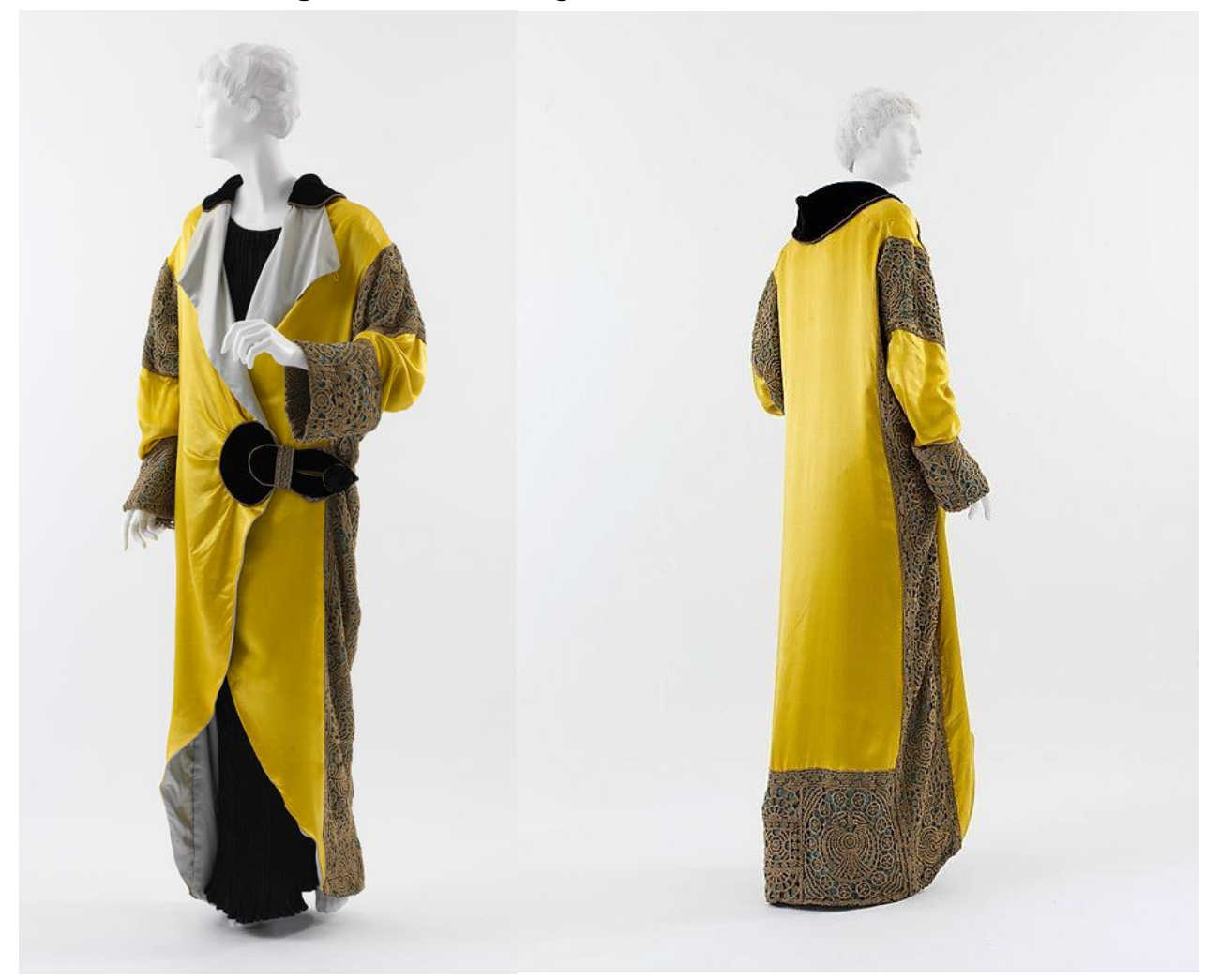

Fonte: www.metmuseum.org

Figura 136 - Evening Coat, Paul Poiret, 1912

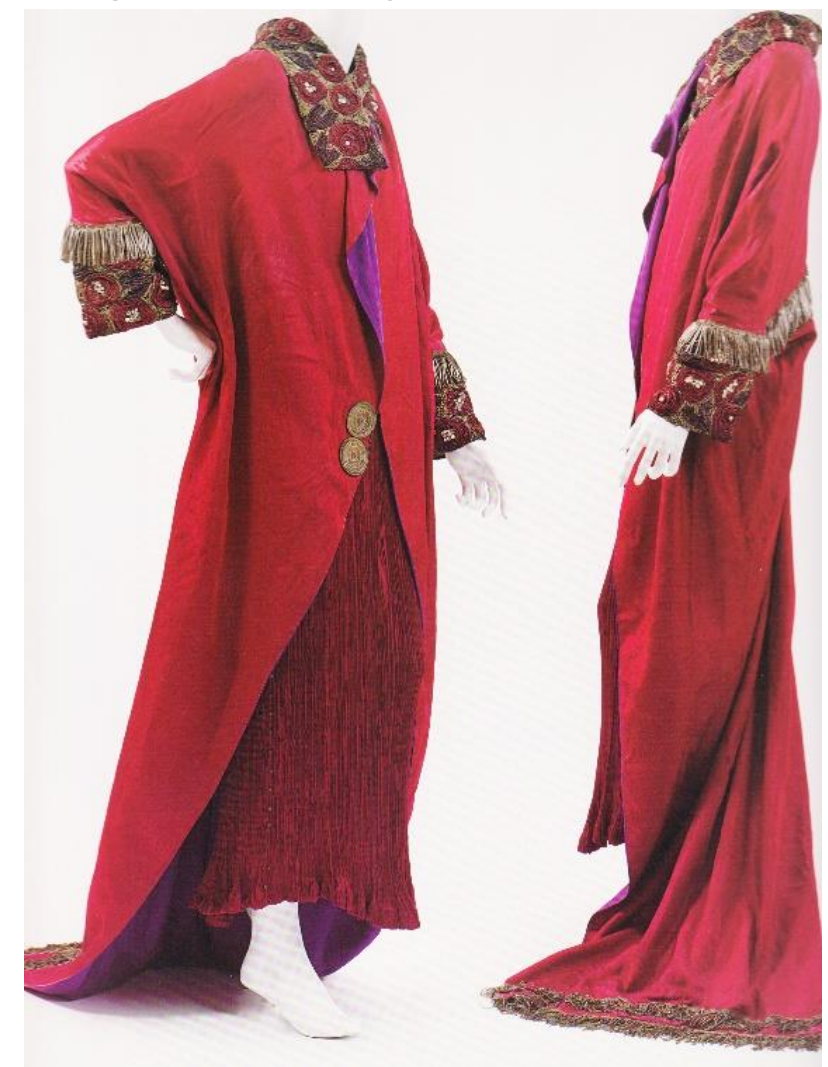

Fonte: Koda e Bolton, 2007, p. 86 
Segundo Fukai (2007), além da linha reta e mangas amplas, outros detalhes da construção de Poiret relevam a influência do Japonismo, como no manteau de 1913 (Figura 137). Fukai ainda destaca que a linha do colarinho se relaciona com o estilo nukiemon do quimono, no qual a nuca, área extremamente erótica no Japão, fica exposta.

Figura 137 - Manteau. Paul Poiret, 1913

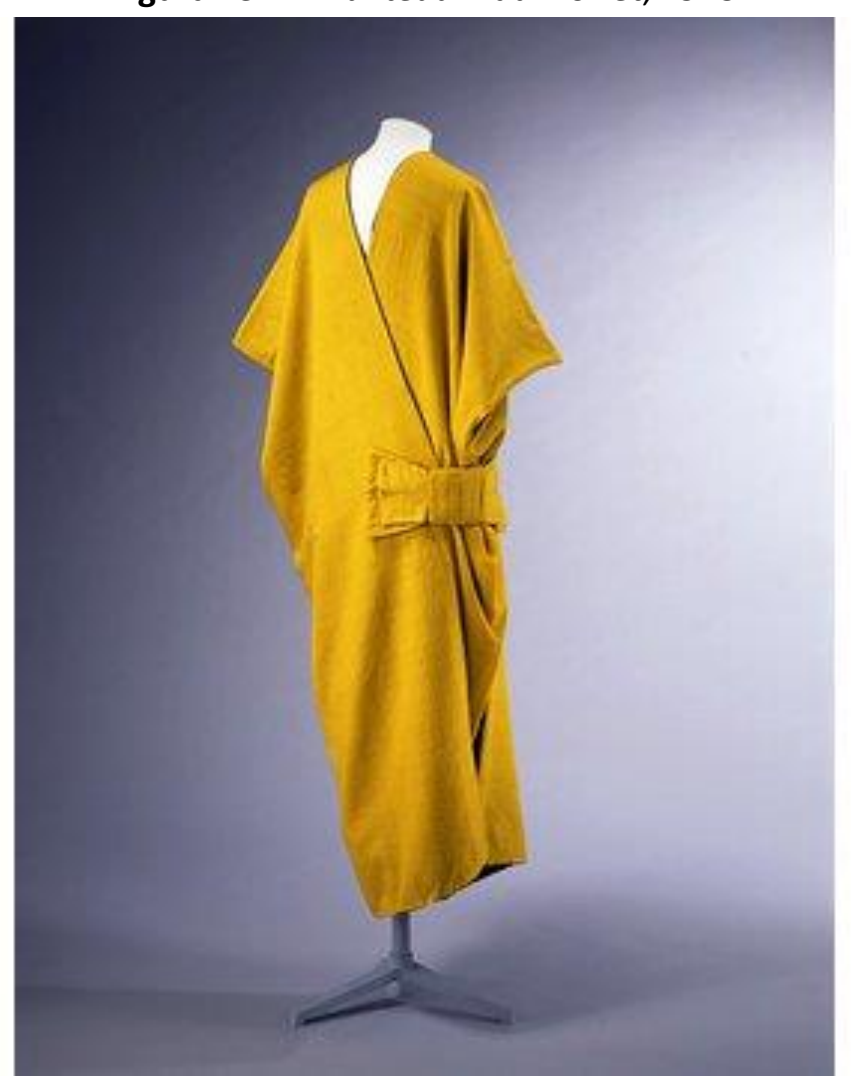

Fonte: http://collections.vam.ac.uk

O casaco La Perse (Figura 138), utilizado por sua esposa Denise Poiret é outro casaco quimono desenvolvido por Poiret. A estampa, criada por Raoul Dufy (1877-1953), apesar de ser resultado da fusão e da interpretação de muitas referências, as características da estética e técnica do ukiyo-e são evidentes, principalmente nos padrões chapados e com cores sólidas, impressos com blocos de madeira. Dufy era um artista fauvista muito influenciado por Toulouse Lautrec (CASPROWIAK, 2008), evidenciando que o Japonismo se traduziu e se desdobrou de muitas formas no século XX. 
Figura 138 - Casaco La Perse, 1911

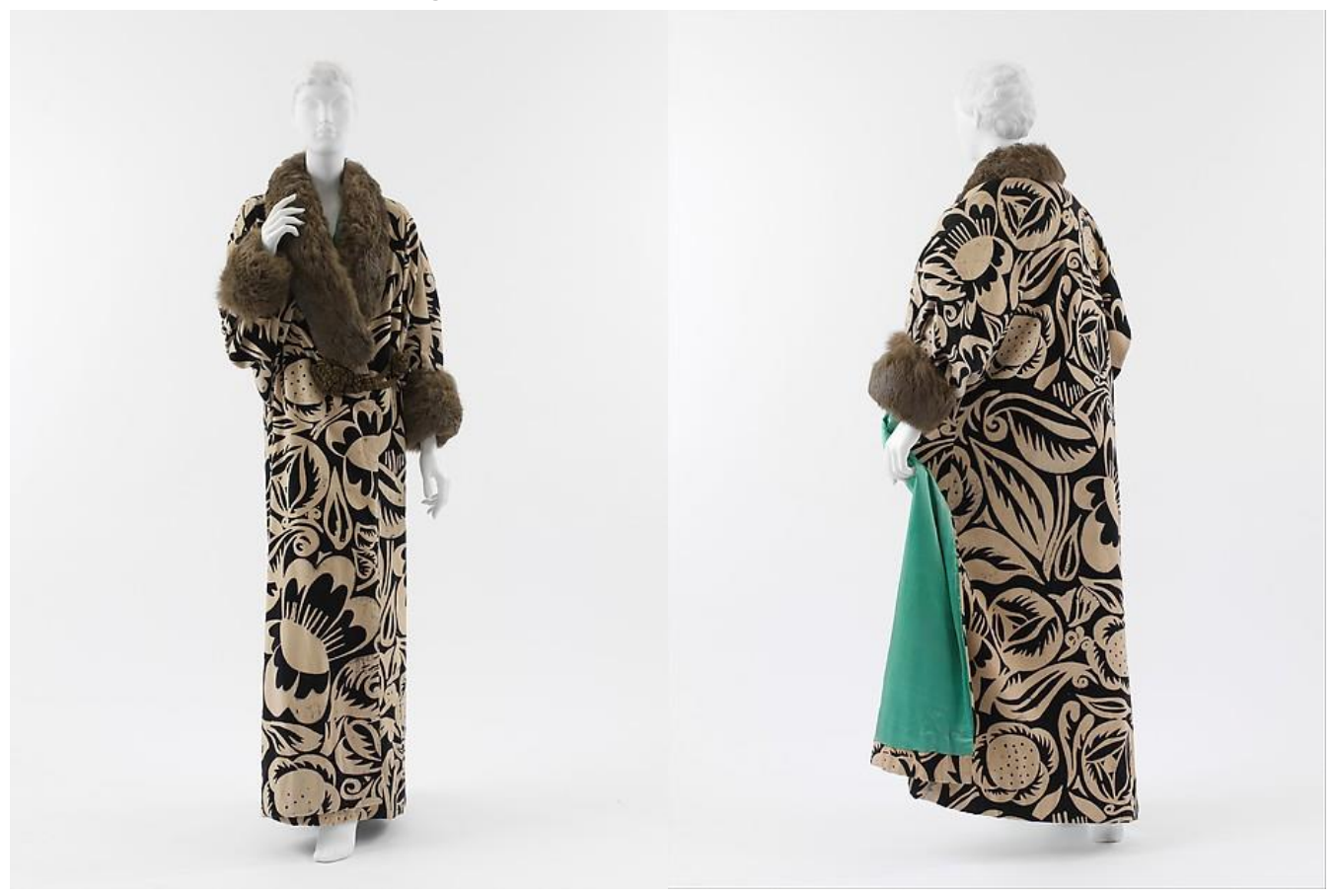

Fonte: Koda e Bolton, 2007, pp. 68 e 69

Em uma das suas muitas ações de autopromoção, Poiret também se uniu aos ilustradores Paul Iribe (1883-1935) e Georges Lepape (1887-1971) para produzir os famosos álbuns Les robes de Paul Poiret (1908) e Les choses de Paul Poiret (1911), distribuídos gratuitamente à sua clientela de elite. Ambos os ilustradores utilizavam a técnica de estêncil pouchoir, inventada no Japão, de modo a originar brilhantes e saturadas áreas de cor (KODA; BOLTON, 2007). Há de se considerar também os contornos delineadores, a bidimensionalidade e a despreocupação com o realismo, que muito se assemelham às xilogravuras japonesas onipresentes na Europa, resultando em ilustrações bem diferentes das detalhadas e literais ilustrações oferecida pela mídia. 
Figura 139 - Casacos quimono representados no álbum Les Robes de Paul Poiret, ilustrado por Paul Iribe, 1908

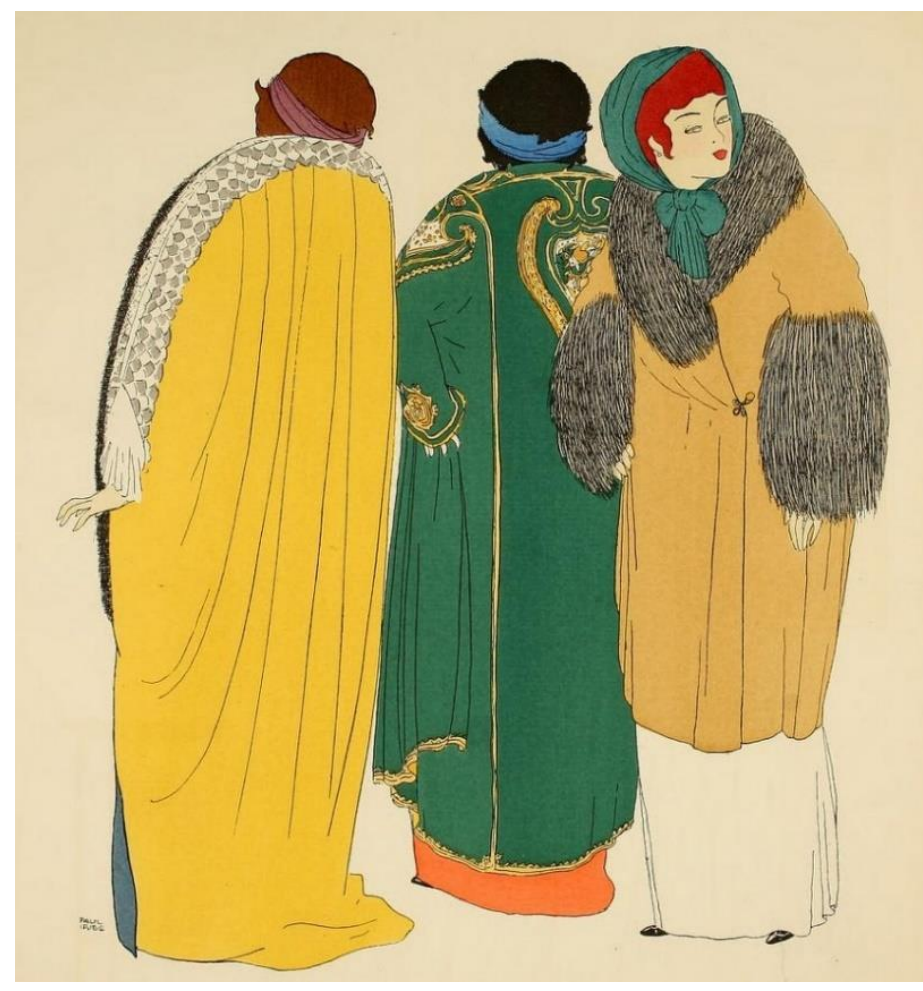

Fonte: http://www.metmuseum.org

Figura 140 - Opera Coat no álbum Les Choses de Paul Poiret, ilustrado por Georges Lepape, 1911

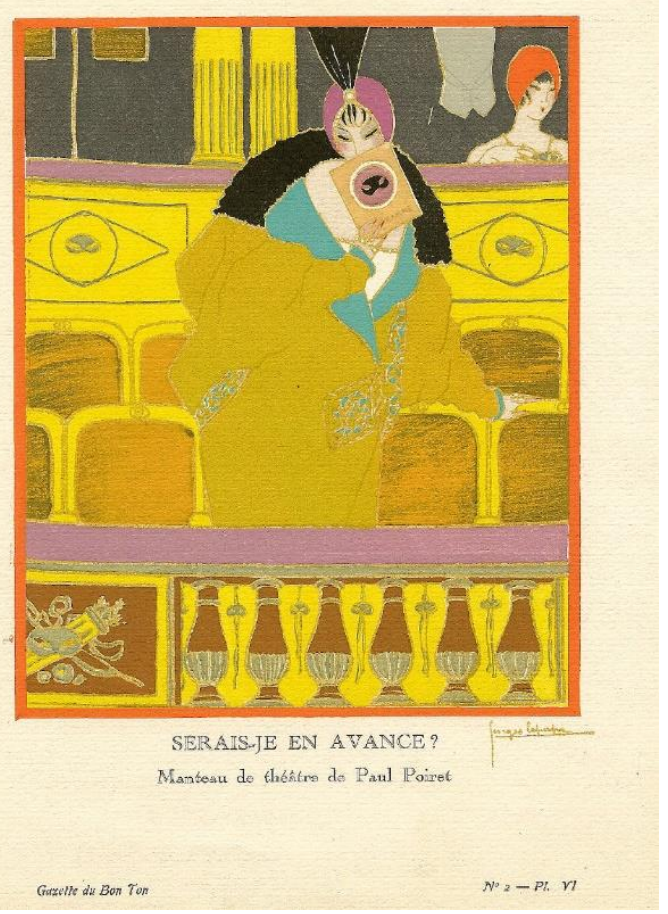

Fonte: www.artnet.com 
Fukai (2007) descreve que, nesse período, se desenvolveram as mídias de diculgação de tendências de moda cuja influência espalhou-se rapidamente. Os desenhos de moda possuíram papel dominante em revistas como Vogue e Gazzette du Bon Ton, nas quais os ilustradores viviam sua era de ouro. Abaixo, duas capas da Revista Vogue expõem a nova abordagem do corpo que Poiret estabelece.

Figura 141 - Capas da Revista Vogue, 1917 e 1920
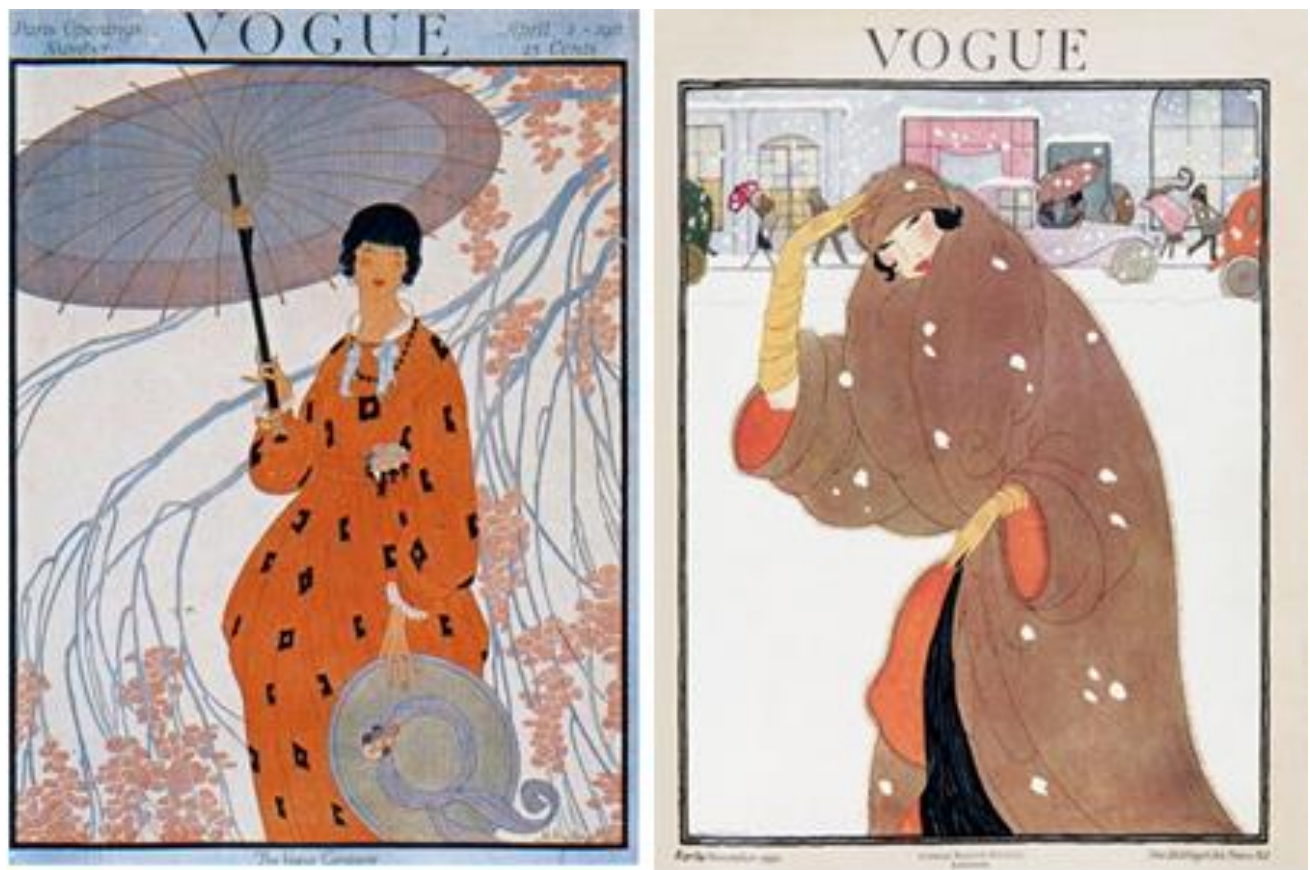

Fonte: http://www.condenaststore.com

O leque, acessório já mencionado anteriormente, tornou-se material de divulgação no começo do século XX; desse modo, foi utilizado por Poiret para impulsionar seu perfume Rosine. Nesse entendimento, Silver (2007) diz que, por criar pioneiramente itens cosméticos e objetos decorativos atrelados à sua marca, ele é considerado o primeiro designer a oferecer o conceito de "total lifestyle".

O Manteau D'Auto de 1912 é outro exemplo de como ele utilizava de forma bemsucedida o intercâmbio cultural a seu favor. Nesse período, de acordo com Koda e Bolton (2007), casacos contra a poeira para serem usados nos carros tornaram-se necessários devido às cabines abertas e as ruas despavimentadas; daí o nome manteau d'auto: casaco de automóvel. A interpretação de Poiret para essa peça possui não só inspiração na abaya norte africano como também absorve elementos provenientes do quimono japonês, como o decote 
e o fechamento assimétrico transpassado. A hibridização de elementos ocidentais e nãoocidentais tornou-se uma estratégia aplicada por Poiret ao longo de toda sua carreira; porém, diferentemente do Japonismo visto anteriormente, suas criações nunca eram vulgares, mas celebravam as diferentes culturas com imenso respeito, resultando em trajes únicos, possíveis apenas no Oriente fictício de sua imaginação (SILVER, 2007).

Figura 142 - Manteau D’Auto, casaco usado por Denise Poiret. Paul Poiret, 1912

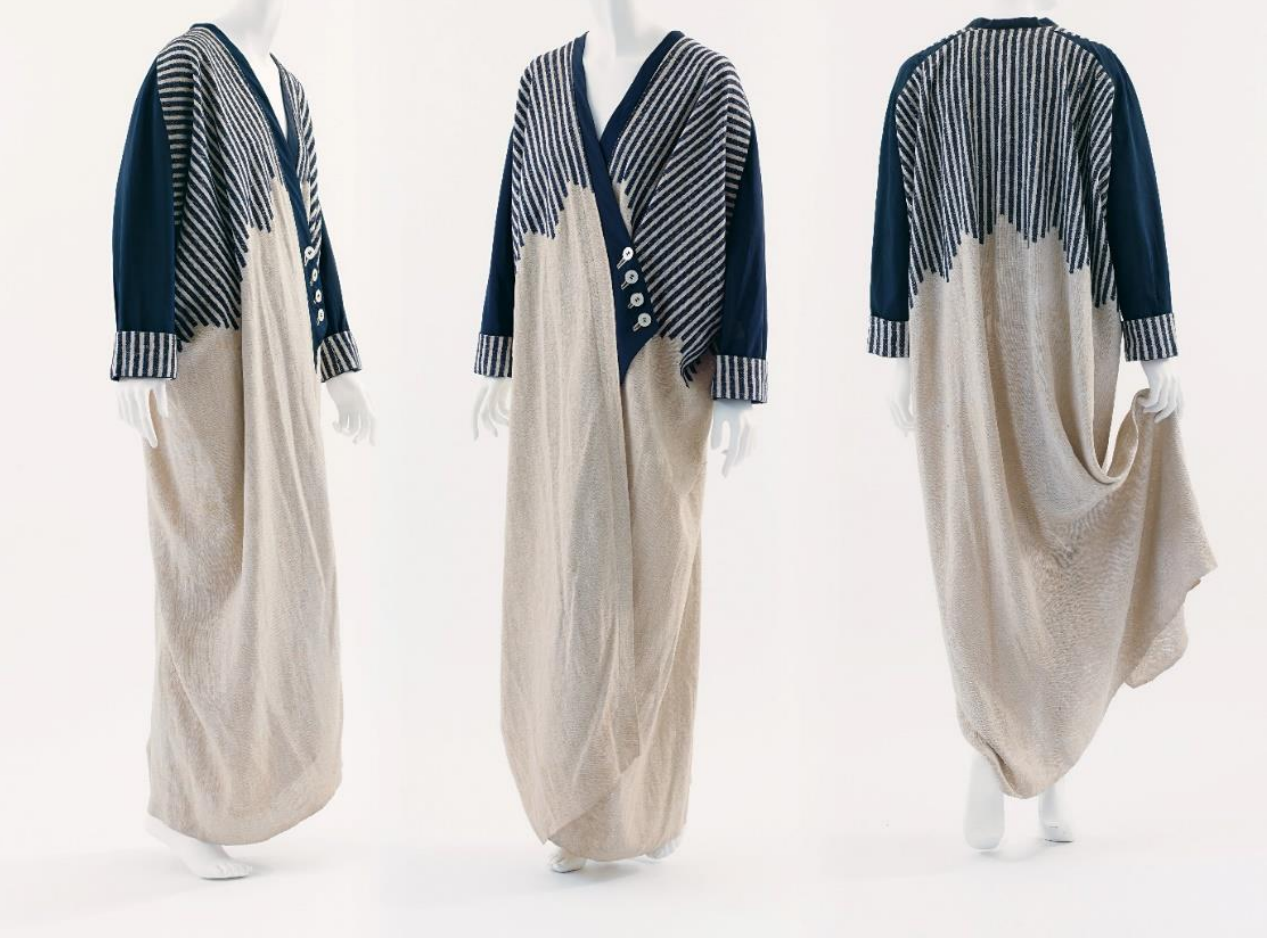

Fonte: http://www.metmuseum.org

Outra inovação concretizada por Poiret, talvez a mais radical de sua carreira, tenha sido a silhueta chemise. Conforme Koda e Bolton (2007), em resposta à necessidade de sua mulher Denise que estava grávida, ele cria vestidos que antecipam em até um década a silhueta simplificada em T, a completa libertação do corpo. Pences e recortes foram eliminados, de modo que o molde da frente e costas tornam-se idênticos, salvo pelo decote. De tão reduzido, ficou conhecido como "Robe de Minuto", por sua rapidez na confecção. Esse vestido foi criado para ser usado na intimidade do lar; apesar disso, ele logo passou a ser utilizado nas ruas. 
Figura 143 - Vestido em estrutura em "T" usado por Denise Poiret. Paul Poiret, 1912

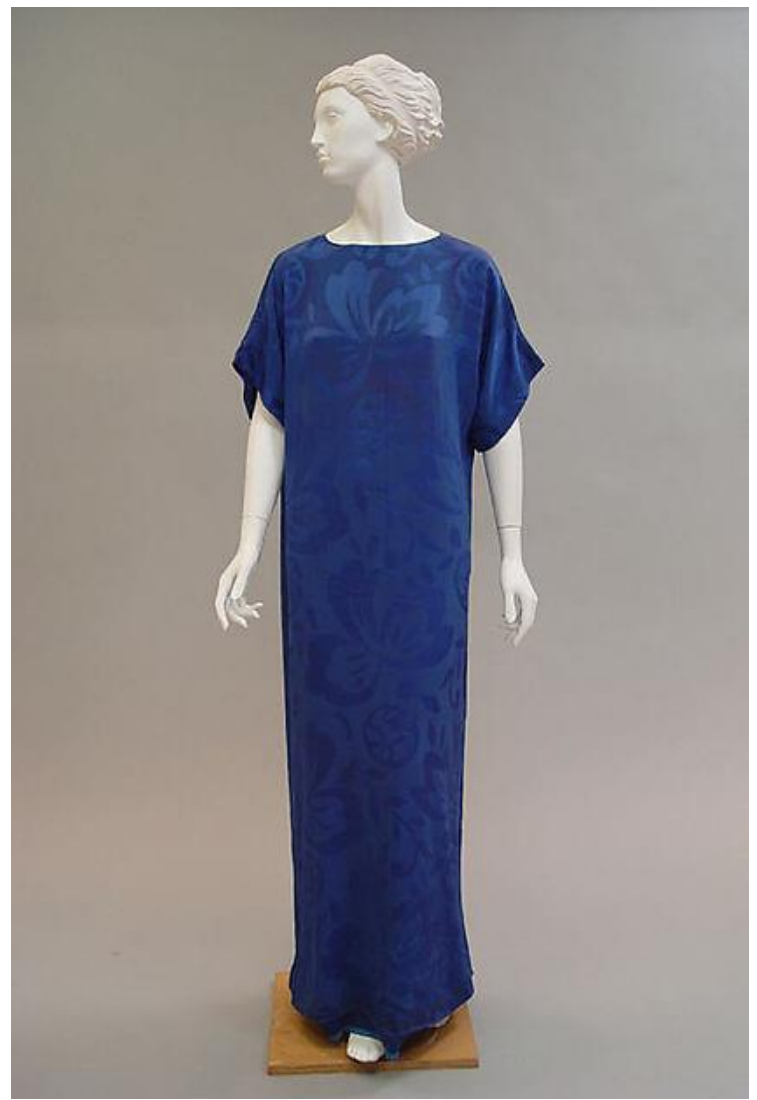

Fonte: www.metmuseum.org

Apesar de múltiplas influências serem visíveis no trabalho de Poiret, o quimono surgiu como um grande aliado na concretização da ruptura das tradições e convenções do ocidente, culminando na restruturação do vestuário. Ainda de acordo com Koda e Bolton (2007, p.13), "Poiret efetivamente estabeleceu o cânone da moda moderna e desenvolveu o diagrama da indústria de moda moderna. Tal era sua visão que Poiret não só alterou o curso da história do vestuário como também conduziu em direção a história do design moderno".

Segundo considerações dos mesmos autores, é irônico afirmar que Poiret rejeitava o modernismo, visto que suas inovações técnicas e comerciais foram fundamentais para que emergisse o design de moda moderno. Porém, mesmo que o orientalismo de Poiret estivesse em consciente desacordo com o modernismo, serviu como a principal expressão de sua modernidade, permitindo com que transformasse radicalmente os princípios da alta-costura. Fukai (2007) salienta que, apesar de não ter sido o propósito norteador de Poiret libertar as mulheres da tirania do espartilho, seus trajes conquistaram tal liberdade, um feito que ninguém, nem mesmo médicos e grupos feministas, conseguira no século XIX. 
Como resultado de sua paixão por tudo que se articulava com as terras distantes e utópicas, é certo afirmar que, antes de ser o primeiro modernista, Poiret foi, sobretudo, um grande orientalista.

Figura 144 - Fotografia de Henri Manuel, modelos vestindo a coleção de Paul Poiret, 1910

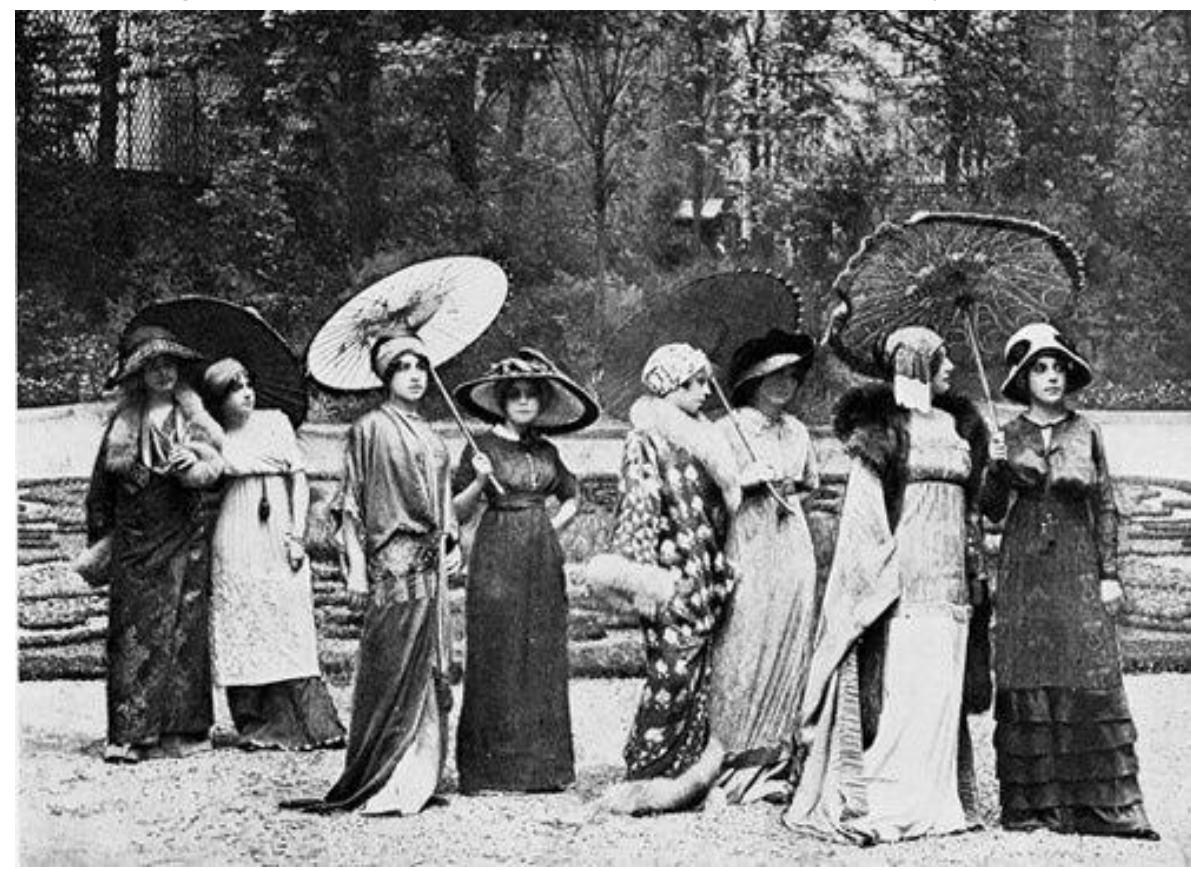

Fonte: Koda e Bolton, 2007, p. 24

Outra designer notável de sua época, a que talvez mais emprestou os conceitos visuais da arte do momento, foi Madeleine Vionnet. Devido à sua apreciação das ideias inovadoras, ela acompanhou de perto o trabalho dos artistas europeus e, assim como muitos deles, configurou-se como colecionadora de longa data das gravuras ukiyo-e; foi uma demonstração não só de um grande interesse pela arte japonesa, mas também pelos seus desdobramentos traduzidos na arte moderna. Dessa forma, ela foi capaz de incorporar complexos elementos derivados do Japonismo, cubismo, futurismo e tantos outros em suas criações (GECZY; KARAMINAS, 2013a). 
Figura 145 - Gravuras japonesas penduradas no ateliê de Madeleine Vionnet

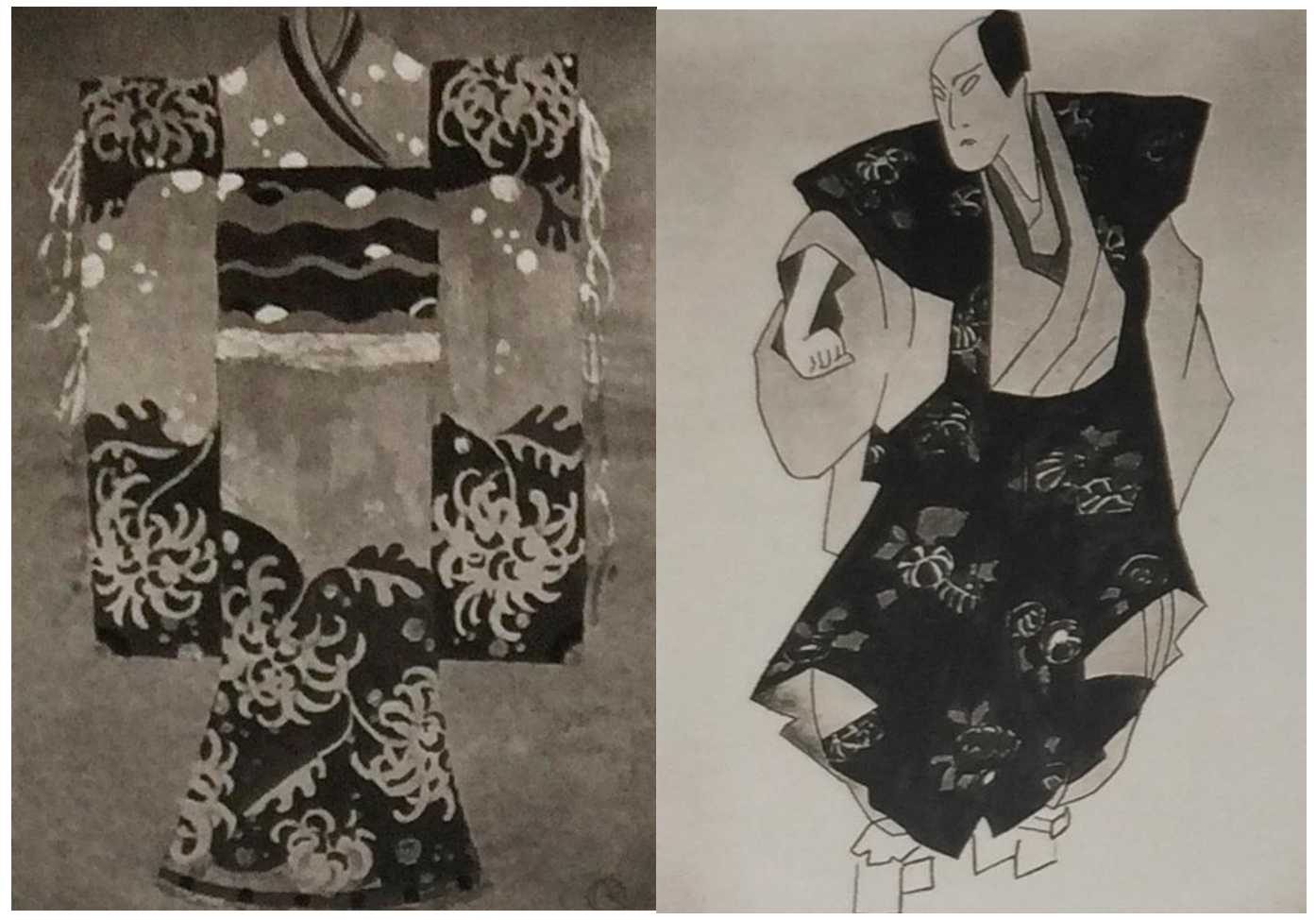

Fonte: Kirke, 2012, p. 46

Vionnet compartilhava com Cézanne e com os cubistas o conceito fundamental da forma abstraída convertida em componentes geométricos simples, ao declarar, como registrado por Driesch (2014, p. 533), que: "o costureiro deve ser um geometrista, pois o corpo humano cria figuras geométricas que os materiais devem corresponder".

Nessa linha de pensamento, a sintetização configura-se como um elemento chave no propósito de Vionnet de revelar a beleza do corpo em si, em contraste com a silhueta restritiva do século anterior. O quimono, com sua peculiar estrutura em " $\mathrm{T}$ ", não almejava encaixar as partes do corpo como é feito na maioria das sociedades ocidentais, mas buscava envolver o corpo ao invés de prendê-lo, concepção vista com muito entusiasmo por Vionnet.

Seu interesse pela estética japonesa se aprofundou em grande parte por influência de Marie Callot Gerber, uma das três irmãs que fundaram a Maison Callot Soeurs, onde trabalhou por alguns anos. A amizade de Mme Gerber com Edmond de Goncourt, o colecionador e crítico de arte apaixonado pelo Japão - já mencionado neste trabalho - levou a Maison Callot Soeurs a frequentemente buscar inspiração na beleza exótica do Japão. De acordo com Kirke (2012), o interesse de Madame Gerber pelo Oriente levou a uma das maiores inovações da moda do século. Ao transferir o extenso ombro dos quimonos oara o vestuário ocidental, ela 
concebeu um novo modelo e formato de mangas, nos quais frente, costas e mangas unem-se em um único corte. Pelo que se sabe, essa foi a primeira vez em que Vionnet ficou defronte a uma grande inovação de estilo e técnica no vestuário, possível devido à fertilização cruzada das duas culturas.

Figura 146 - Adaptação da manga do quimono para o vestuário ocidental

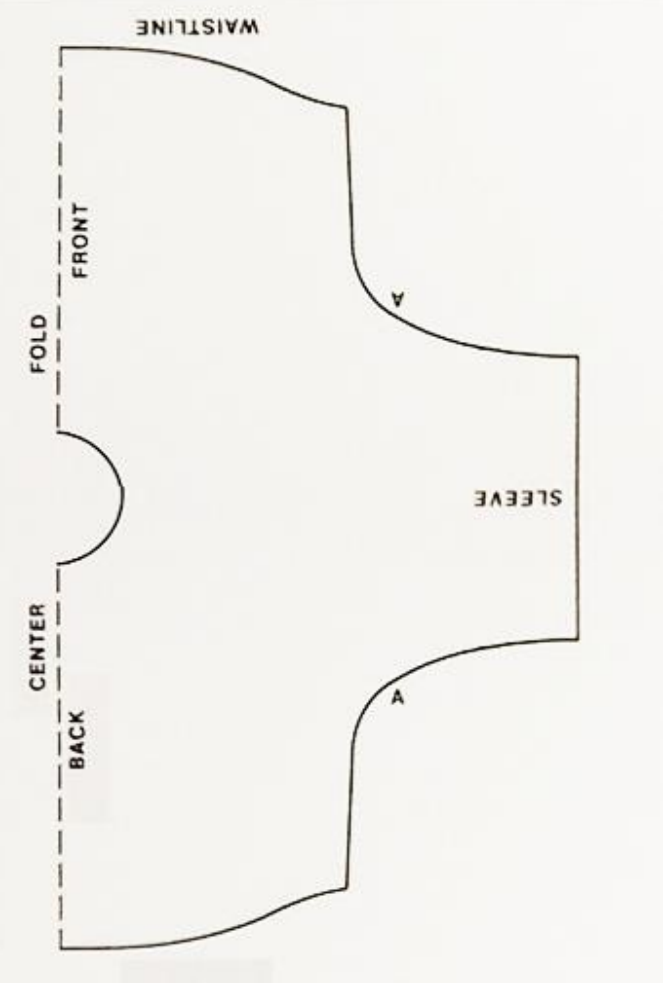

Fonte: Kirke, 2012 p. 33

A experiência e as ideias adquirida na Maison Callot Soeurs revelaram-se inestimáveis para Vionnet, como o conhecimento sobre os tecidos, o fino acabamento e a ênfase no corpo feminino. Posteriormente, ela passa a trabalhar para Jacques Doucet em uma posição de maior destaque. Nem sempre suas ideias eram aceitas, Vionnet; contudo, conseguiu cativar muitas clientes, inclusive atrizes, devido às suas criações simples que enfatizavam o corpo. As atrizes configuravam-se como figuras muito influentes na moda, pois possuíam o poder de introduzir novas ideias. Entre essas clientes devotas à simplicidade de Vionnet estava Cécile Sorel (KIRKE, 2012).

Apesar de até hoje a libertação do espartilho ser atribuída a Poiret, Kirke (2012) advoga que foi Vionnet quem pioneiramente expõe uma coleção totalmente desvinculada do 
espartilho. Ela teria dito, conforme Kirke (2012, p. 35) "Eu nunca fui capaz de tolerar o espartilho, então por que eu deveria impor às outras mulheres? ". Inspirado no deshabillé traje utilizado para se ficar em casa - e também na atriz americana Isadora Duncan (18771927), que se apresentava totalmente livre, sem sutiã, espartilho ou sapatos, Vionnet cria a coleção de deshabillés para serem usados fora dos perímetros de casa; porém, na ocasião sua coleção é totalmente rejeitada.

Em 1912, ela inaugura sua própria casa de costura na rua Rivoli 222, mas no intervalo da Primeira Guerra Mundial (1914-1918), seu ateliê, como muitos outros, é desativado. Durante a guerra, a mulher gradativamente substitui as mais variadas posições nas fábricas e no campo, responsabilidades até então monipolizadas pelo homem, posições essas que, então, passam a fazer parte da realidade feminina. De acordo com Fukai (2007), por evidente, designs simples, saias mais curtas e roupas sob medida tornaram-se as vestes ideais.

No pós-guerra as atividades consideradas frívolas modificam-se e se tornam fisicamente ativas, como a dança e os esportes. O Jazz torna-se muito popular, assim como o ritmo do tango. Uma dinâmica energia acomete esse período e altera drasticamente a moda feminina, que passa a exigir um vestuário simples e funcional, não restritivo aos movimentos físicos (FUKAl, 2007).

Segundo Geczy e Karaminas (2013b), o Ocidente enxerga o corpo como vários aglomerados, não só no vestuário como também na evolução dos estilos; ou seja, exagera ou suprime uma parte do corpo em específico, destacado das outras. Por outro lado, o conceito do vestuário tradicional japonês é concebido como um todo, produzido por peças retangulares de tecido e costuras retas. Pouco ou nada se perde de material, pois o traje não é endereçado a um corpo específico, nem possui como objetivo ajustar a assentar as partes do corpo, busto, quadril e cintura baseados nas dimensões de um corpo anônimo, mas busca envolvê-lo. Kirke (2012) afirma que Vionnet desenvolveu uma variedade de ideias a partir do quimono tradicional japonês.

As figuras abaixo expõem algumas dessas ideias. Na Figura 147 pode-se perceber sua fascinação com a manga ampla, talvez legado de sua trajetória na Maison Callot Soeurs. Nesta foto, a longa manga furisode está aberta, mas, assim como o kosode, a manga curta, poderia ser enrolada (KIRKE, 2012) 
Figura 147 - Vestido para a duquesa de Gramont. Madeleine Vionnet, Revista Vogue, 1922

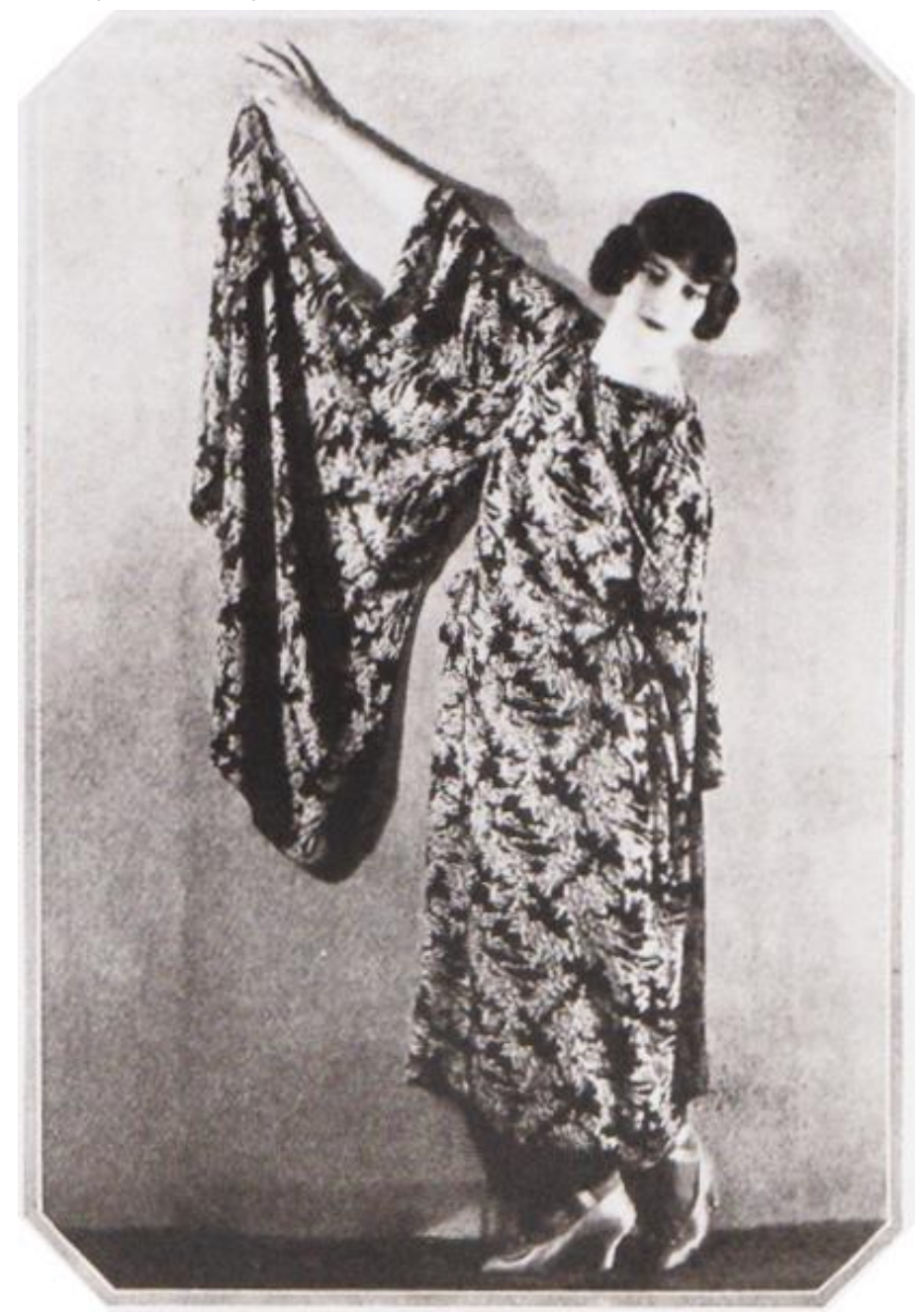

Fonte: Kirke, 2012, p.48

Os dois vestidos abaixo foram inspirados no quimono e possuem elementos característicos específicos como a frente transpassada e as mangas amplas (Figura 148, à esquerda), e a faixa nas costas, com uma imitação do laço borboleta do obi (Figura 148, à direita) (KIRKE, 2012). 
Figura 148 - Vestidos inspirados no quimono, 1922. Madeleine Vionnet. Ilustração de Lisa Feuerherm
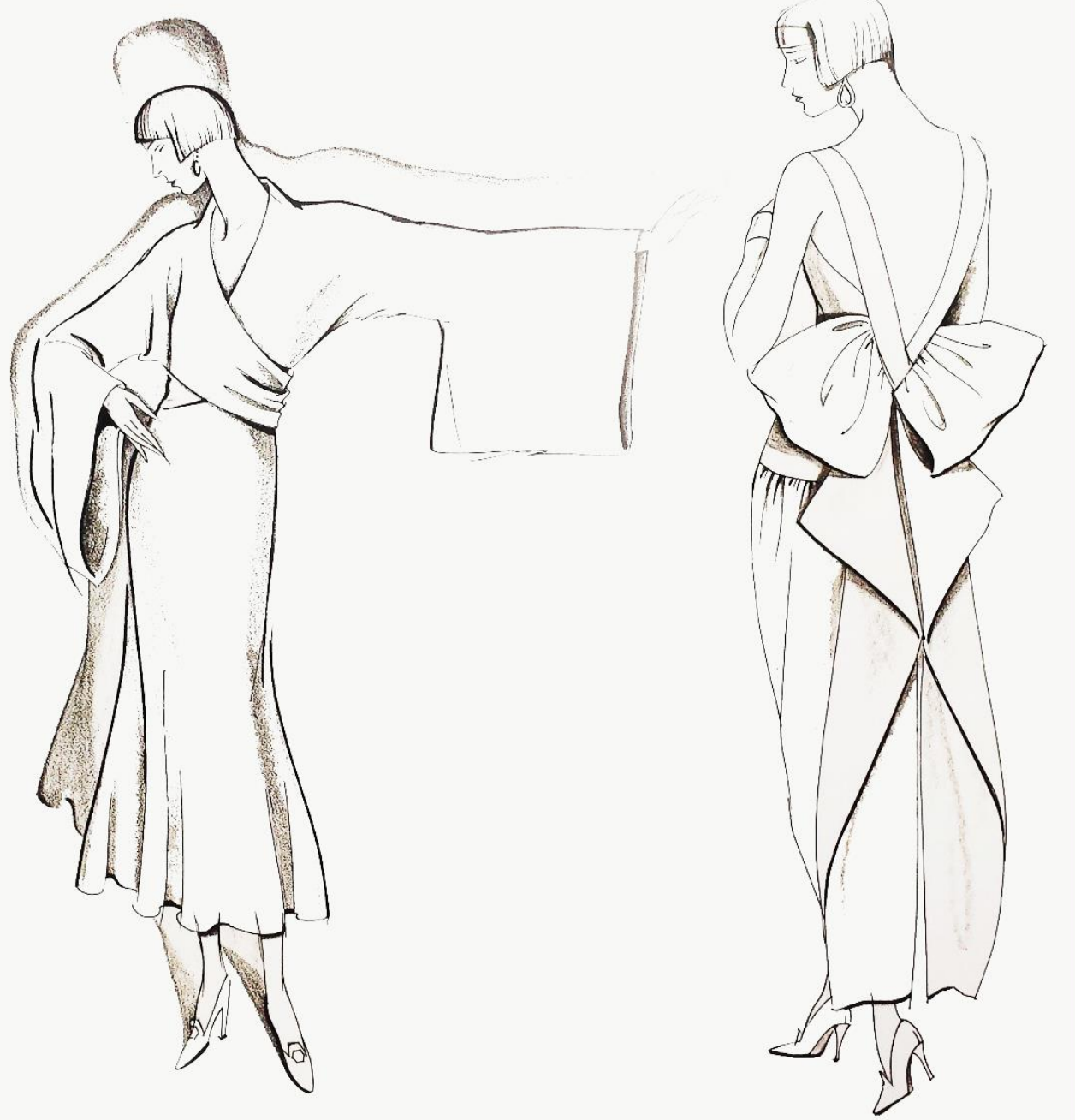

Fonte: Kirke, 2012, p. 48

Madeleine Vionnet foi fiel em seu propósito de posicionar a mulher no centro de sua arte, eliminando qualquer elemento que distorcesse sua forma natural; esse motivo pelo qual ela cria a técnica de corte enviesado que viria a se tornar a sua marca registrada. Utilizada até os dias atuais, essa inovadora técnica permite que o tecido contorne o corpo tridimensionalmente mediante cortes geométricos de tecido posicionados em diagonal, oferecendo liberdade de movimento (DRIESCH, 2014). Também o destaque de Milhaupt (2014, p. 168): “Muitos veem sua marca registrada, o vestido de corte em viés, introduzido em 1919, como sendo inspirado pelo princípio de minimização de tecido, tal como acontece como o quimono". Segundo o mesmo autor, Vionnet estava em Paris durante a Exposição Internacional de 1900, quando a performance da artista Sadayakko causou grande agitação. Mesmo que não possa ser afirmado, é provável que esse momento tenha reforçado a impressão do quimono em Vionnet. 
Em sua trajetória, ela explorou as mais diversas formas geométricas em várias fases de sua carreira, como o retângulo, o triângulo e o quadrante, em conjunto com elementos visuais como a repetição e a gradação. No período logo após o pós-guerra, Vionnet concentrou-se no formato e na estrutura retangular, que, assim como o quimono, deveria circundar o corpo, envolvendo-o.

Figura 149 - Vestido de Vionnet confeccionado apenas com quadrados de tecido, 1919

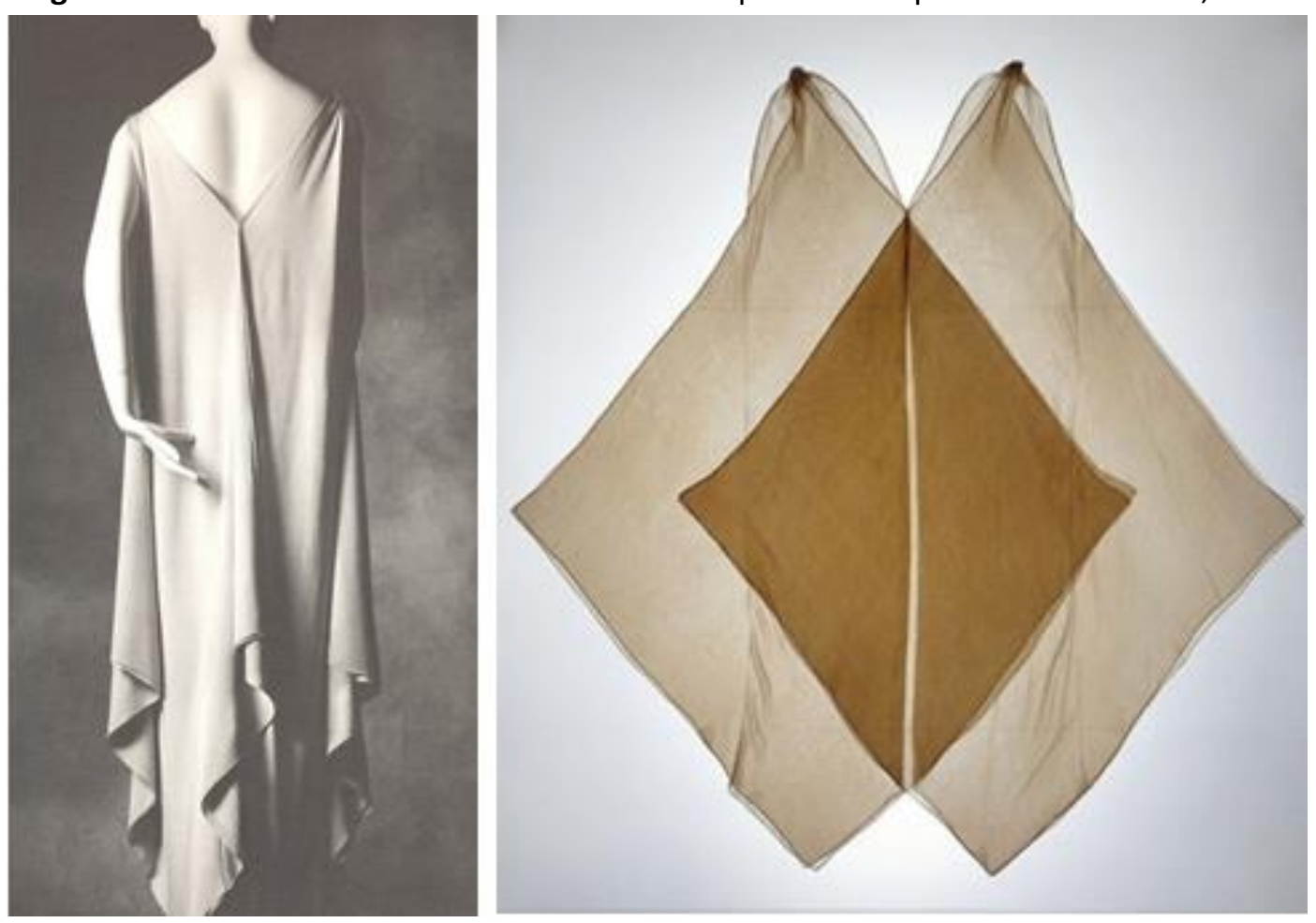

Fonte: immatureindefinitely.wordpress.com 
Figura 150 - Molde do vestido da Figura 149

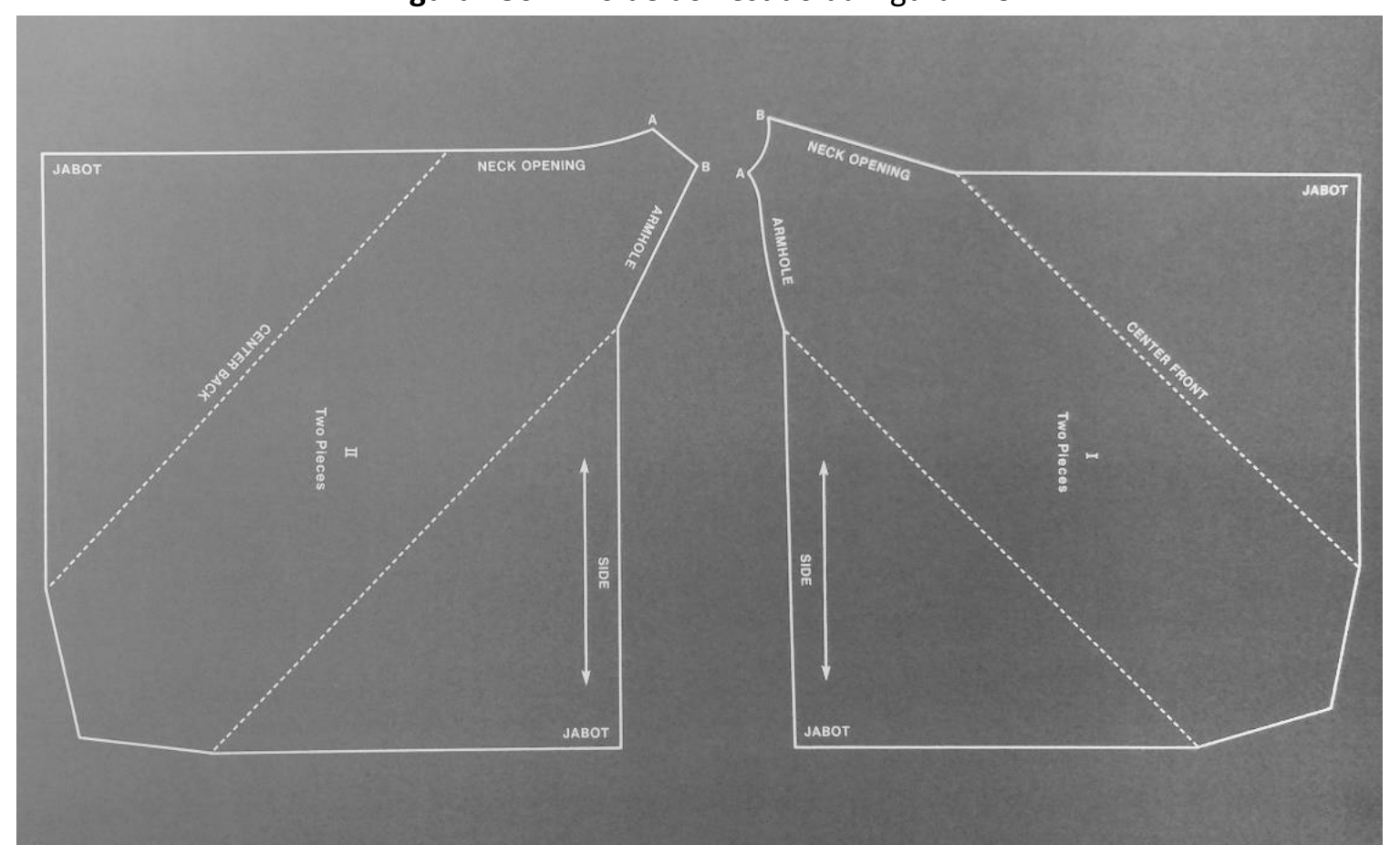

Fonte: Kirke, 2012, p. 54

O vestido mostrado na Figura 149 foi confeccionado completamente no sentido do viés e somente por meio de quadrados de tecido; no seu aspecto técnico é simples não somente no corte, mas também na construção. Presos aos ombros, as partes são apenas costuradas em forma de tubo para cobrir o corpo, ao mesmo tempo em que previnem a deformação do formato quadrado, como é possível observar no molde planificado da Figura 150. Mesmo que simples e reducionista em sua concepção, o resultado se mostra extremamente bem-sucedido; possui belos efeitos assimétricos, fluidez e liberdade de movimento.

Outro exemplo de sua genialidade é o vestido da Figura 151, inspirado nos vestuários grego e japonês. De base retangular, é engendrado para possuir o mínimo de cortes e costuras de tecido, de modo a originar uma leveza incomum. 
Figura 151 - Vestido de base retangular. Madeleine Vionnet, 1921

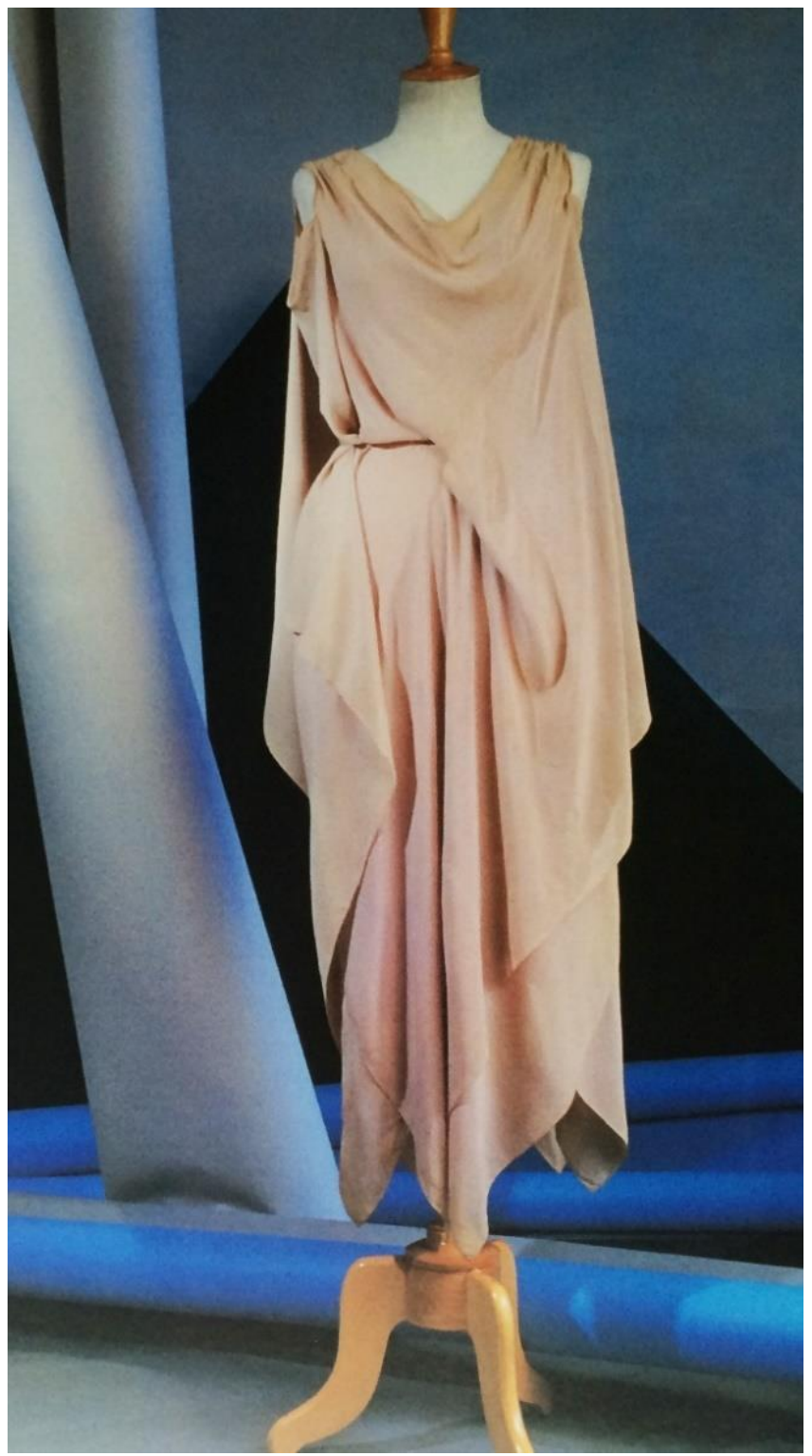

Fonte: Kirke, 2012, p. 49

As figuras comparativas 152, 153 e 154 expõem, de forma clara, a ruptura que Vionnet promove, de modo que seus moldes simplificados muito mais se relacionam com a estrutura do quimono em comparação com a moda ocidental em voga, com seus complexos moldes. Desse modo, Vionnet elimina as barreiras de "frente" e "costas", pois o todo torna-se um cilindro em volta do corpo. 
Figura 152 - Molde Planificado do Quimono

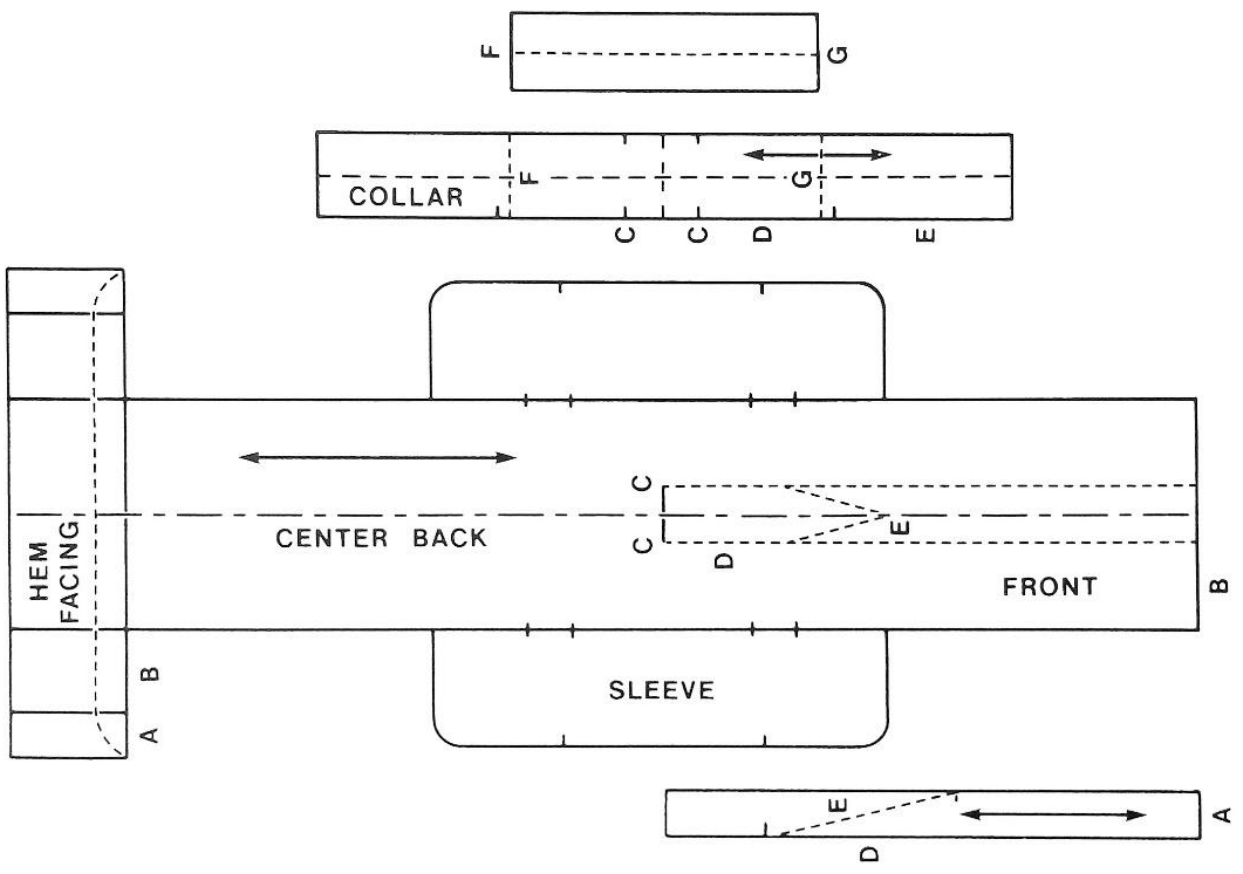

Fonte: Kirke, 2012, p. 46
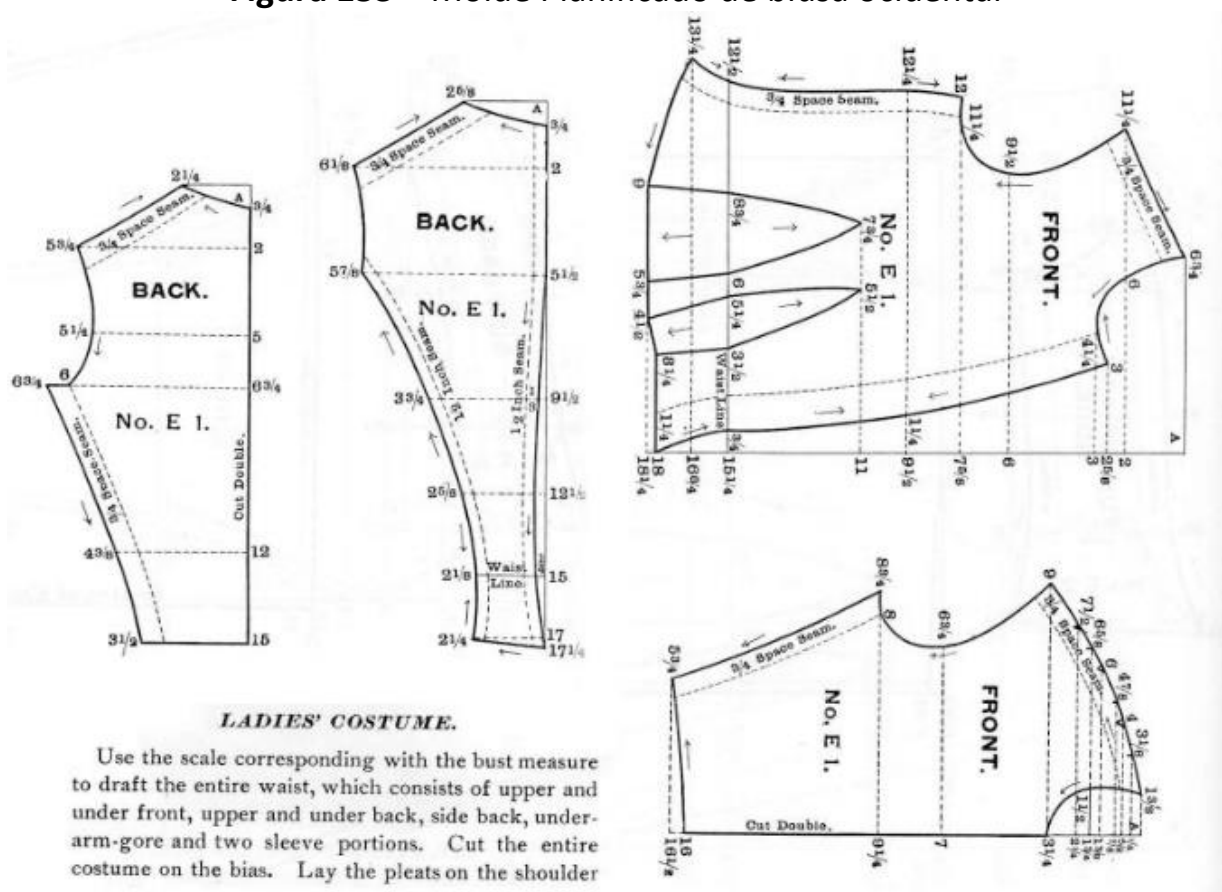

Figura 153 - Molde Planificado de blusa ocidental

Fonte: https://www.pinterest.com/pin/7606868117721036 
Figura 154 - Molde do vestido de base retangular (Figura 151). Madeleine Vionnet, 1921

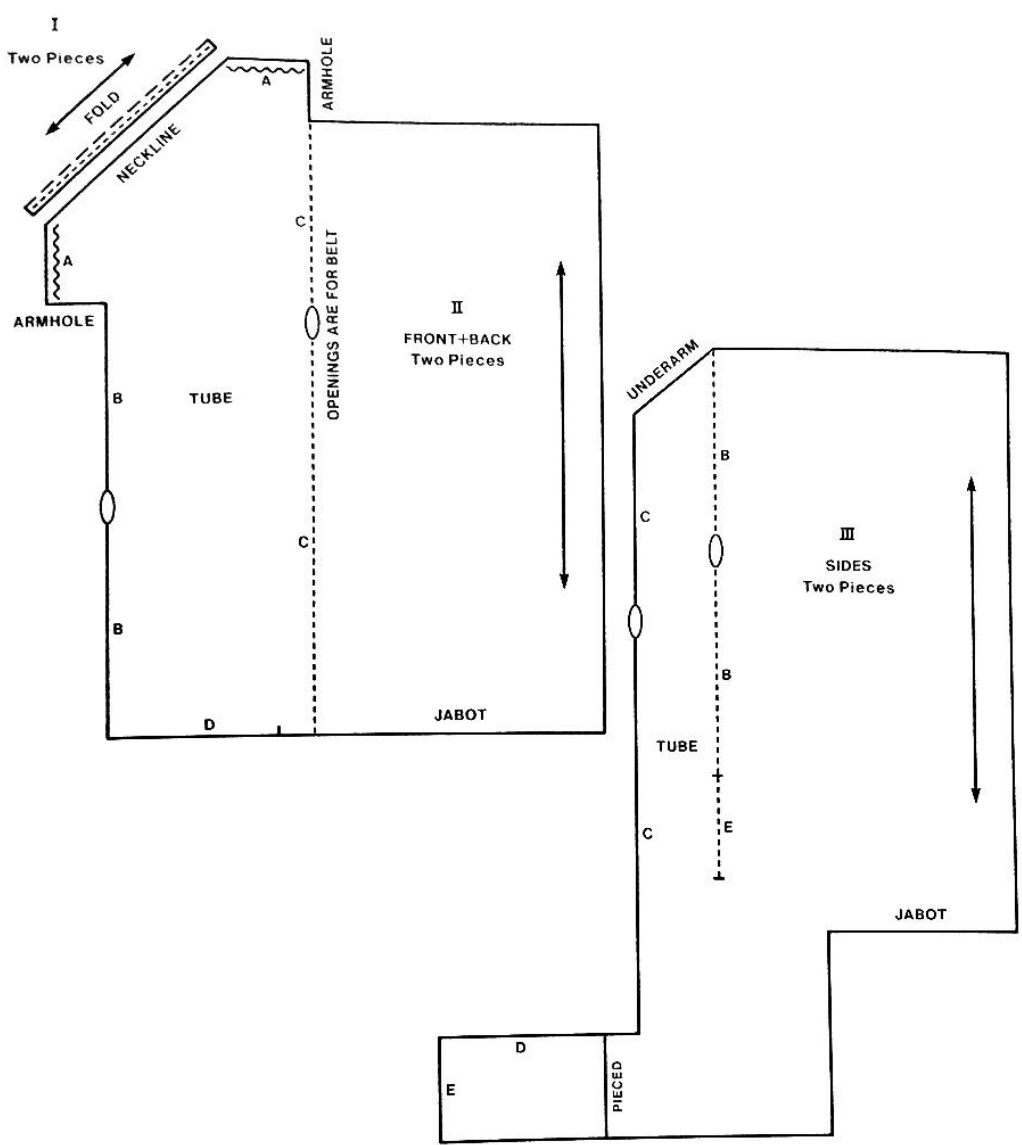

Fonte: Kirke, 2012, p. 47

Segundo Kirke (2012), Vionnet almejava alcançar o “movimento" do vestuário grego com a "linha fluida" do quimono japonês. O vestido abaixo, denominado Japonika, expõe a influência do quimono mediante a faixa oblíqua no quadril, simulando o obi. 
Figura 155 - Japonika, Madeleine Vionnet, 1924. Ilustração de Thayaht

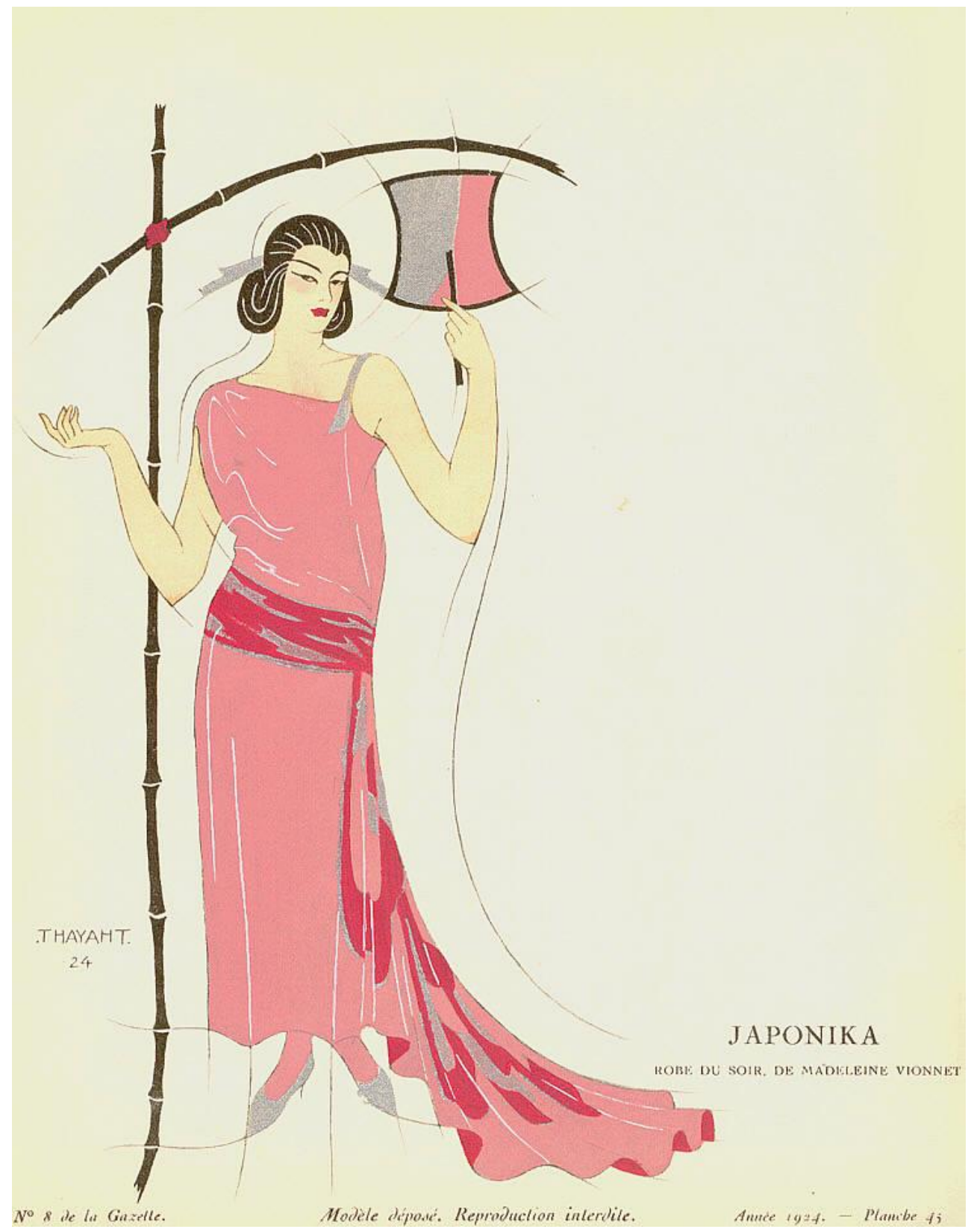

Fonte: www.rijksmuseum.nl

O vestido Japonika foi a última interpretação que Vionnet fez do quimono. Porém, suas características continuaram a influenciar suas últimas criações. Kirke (2012) afirma que o simples enrolar das mangas do quimono levaram à criação de seu popular cachecol Mobius Band. O singelo enlaçamento da faixa e a torção, como mostra a Figura 156, resultam em um cachecol que se mantém atado seguramente ao pescoço. 
Figura 156 - Cachecol Mobius Band

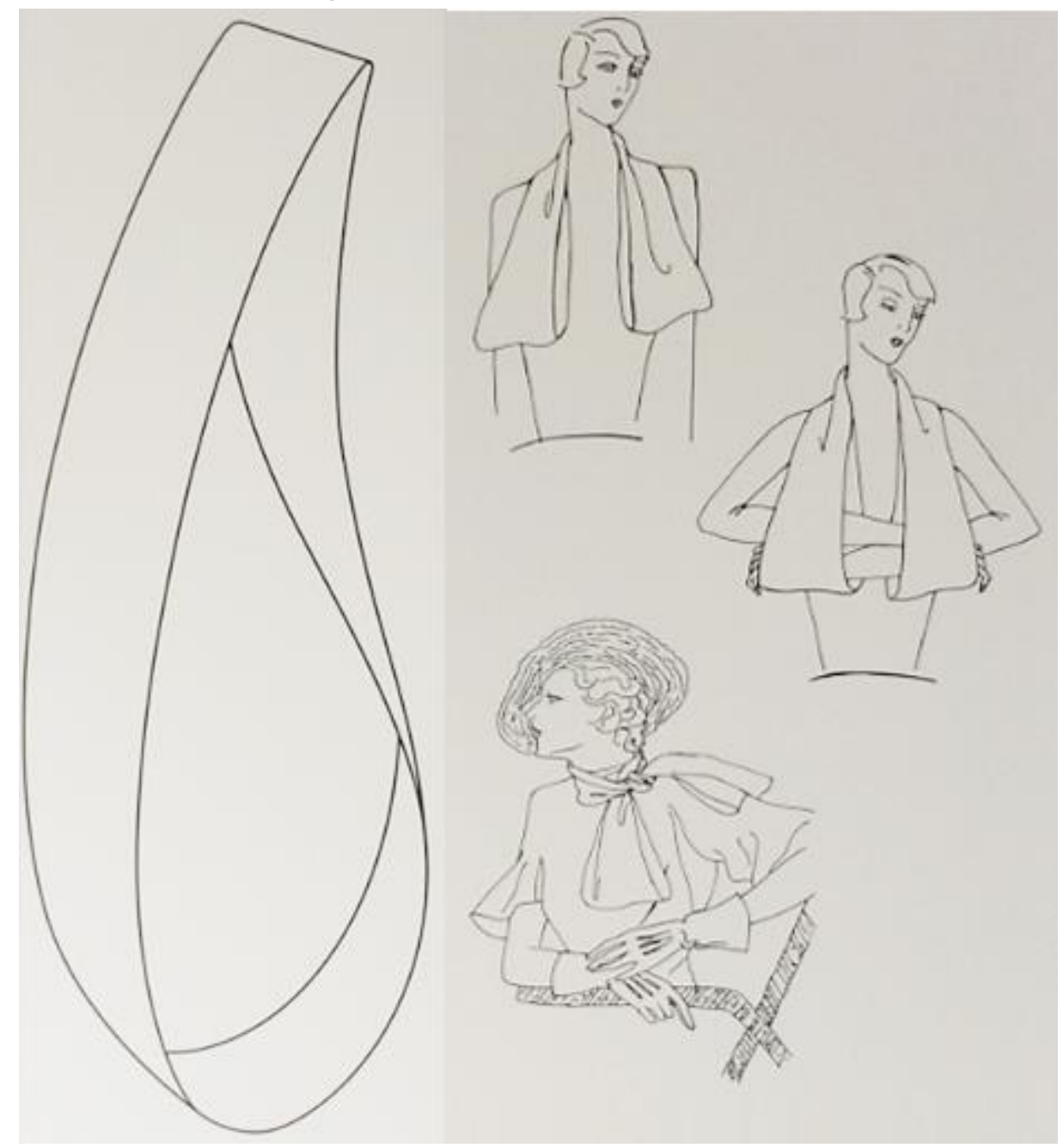

Fonte: Kirke, 2012, p. 72

Os vestidos de Vionnet, nas palavras de Milhaupt (2014, p. 168) "valorizaram a materialidade e a forma do tecido bidimensional". Assim como o quimono, que busca enfatizar o material utilizado, a ornamentação dos vestidos de Vionnet também pertenceriam à estrutura, ao invés da aplicação de bordados, estampas, laços e babados tão comuns na moda da época anterior. Se ela era capaz de unir forma, ajuste e corte de maneira coesa, a ornamentação de superfície também faria parte desse todo.

$\mathrm{Na}$ saia do vestido da Figura 157, Vionnet utiliza faixas de tecidos dobrados alternadamente como o origami, de modo a criar uma interessante textura com formato triangular. Apesar de parecer simples, essa manipulação revela uma construção complexa que requer técnica excepcional (FUKAI, 2007). 
Figura 157 - Detalhe do vestido de Madeleine Vionnet, 1918-1919

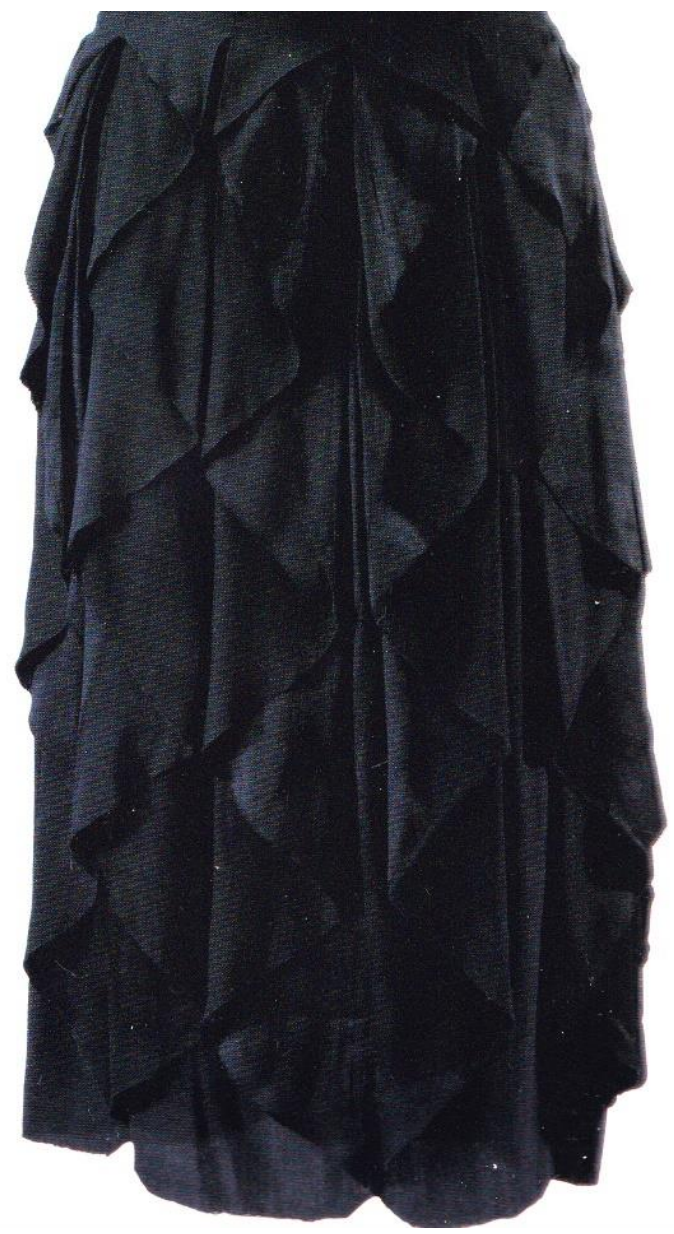

Fonte: Fukai, 2007, p. 362

Outros detalhes relacionaram-se com o Japonismo e com as manifestações artísticas pela forma do triângulo, como a decoração de superfície do vestido da Figura 158, em leques estilizados. 
Figura 158 - Bordado com motivos de leque. Fotografia de Edward Steichen, Revista Vogue, 1925

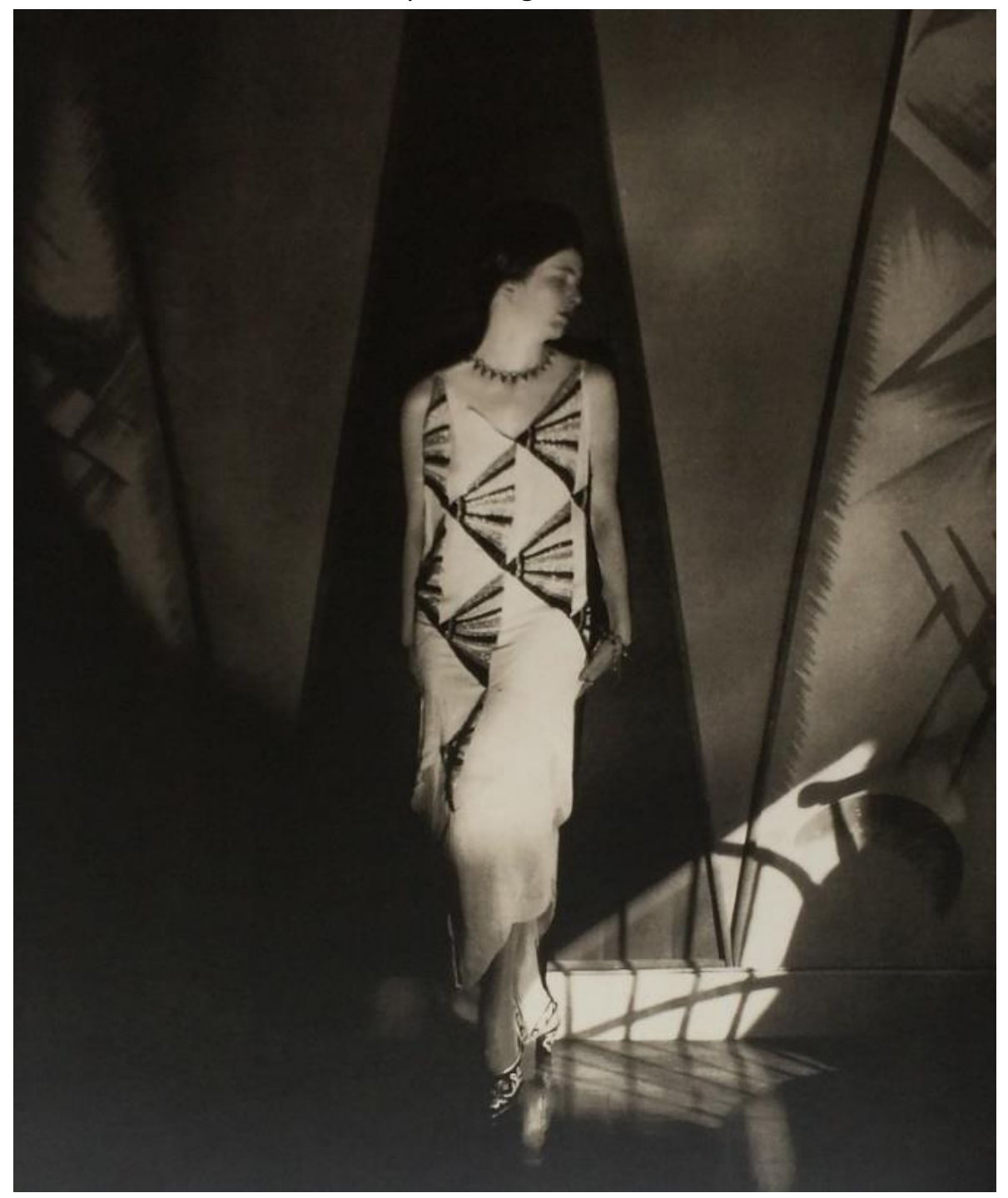

Fonte: Fukai, 2007, p. 370

Outras ornamentações utilizadas posteriormente por Vionnet possuem vínculos com o Japão, como as andorinhas, bordadas em um vestido de 1938 , e o padrão seigaiha, que, literalmente, significa "onda do mar azul". Este é um padrão típico e tradicional japonês que foi muito usado no estilo Art Déco, dominante na década de 1920 (FUKAI, 2007) 
Figura 159 - Imagens comparativas: seigaiha tradicional e vestido de Madeleine Vionnet
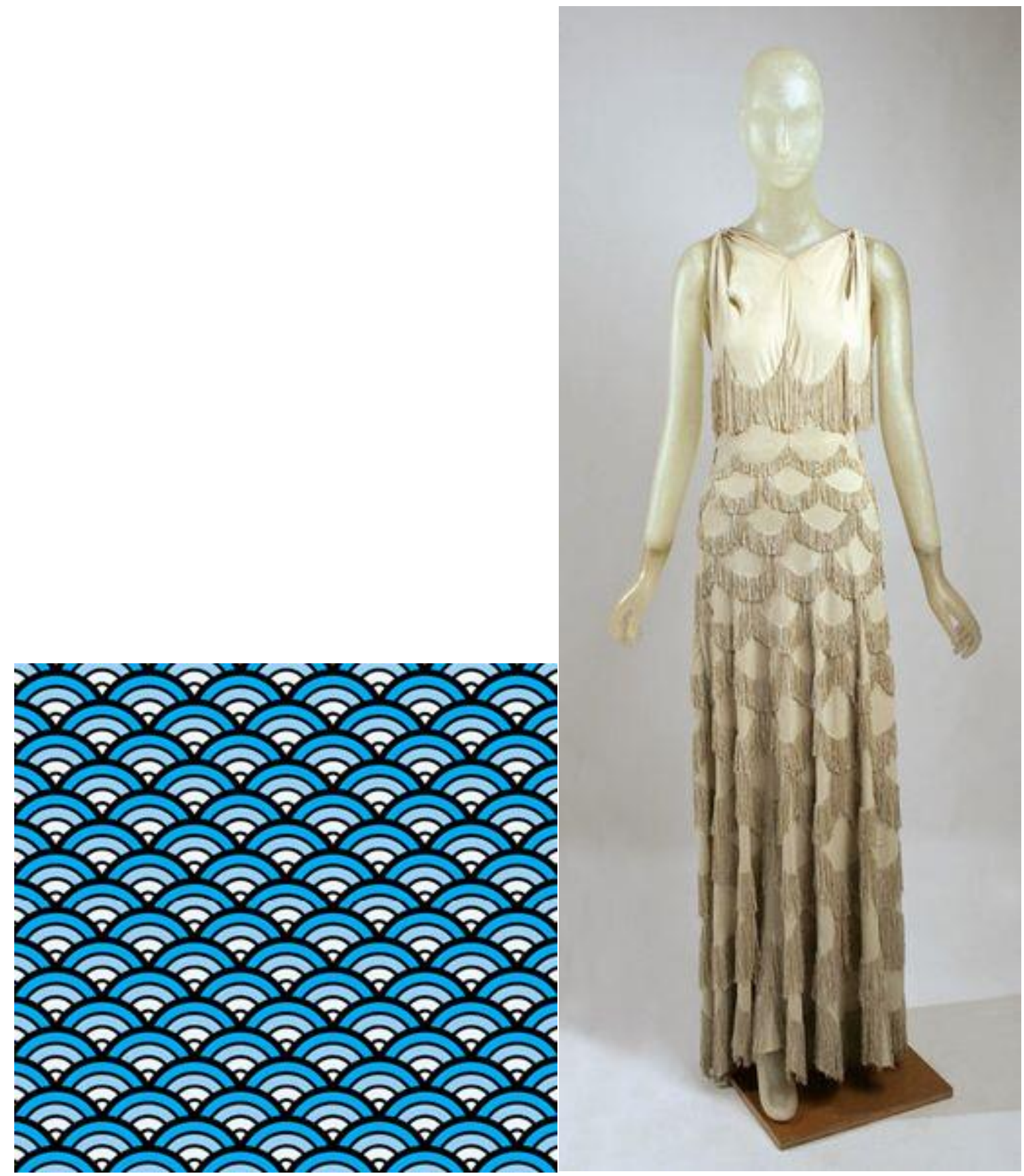

Fonte: http://project-japan.jp/seigaiha

Fonte: www.metmuseum.org

O vestido Henriette (Figura 160), não só é confeccionado por formas geométricas, como também sua ornamentação provém da própria construção, neste caso, reminiscente da laca dourada japonesa, principalmente o makie, a laca dourada (FUKAI, 1994).

No começo do século $X X$, vários designers ocidentais desenvolveram produtos com referências aos laqueados nipônicos. Fukai (2007), relata que Jean Dunand (1877-1942) 
desenvolve um "tecido laqueado", conhecido como lamê. Brilhante e com textura flexível, foi frequentemente utilizado na década de 1920 por Vionnet (FUKAI, 2007).

Figura 160 - Vestido Henriette. Madeleine Vionnet, 1923

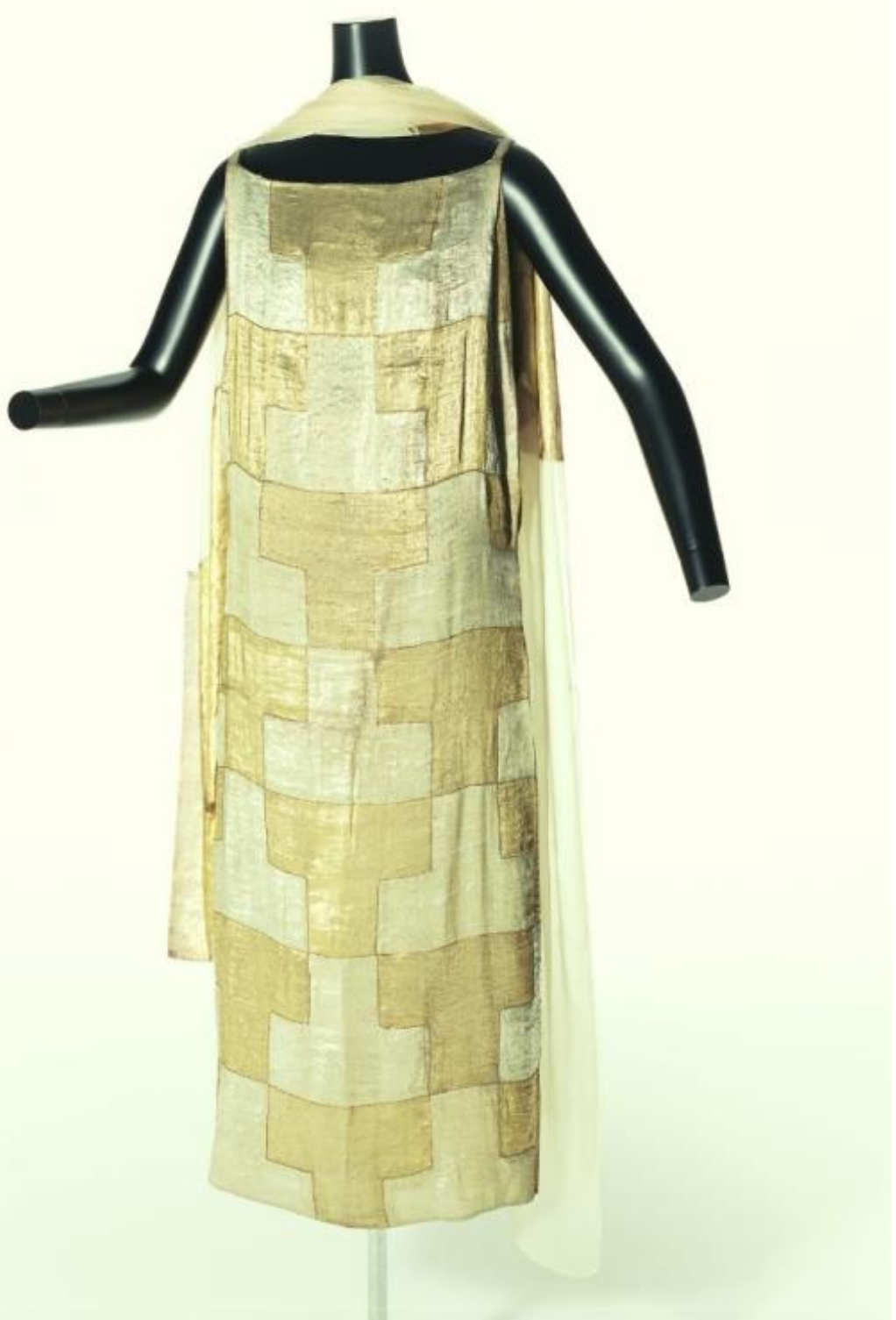

Fonte: http://www.kci.or.jp/archives/digital_archives/detail_134_e.html 
Figura 161 - Vestido Noturno de lamê

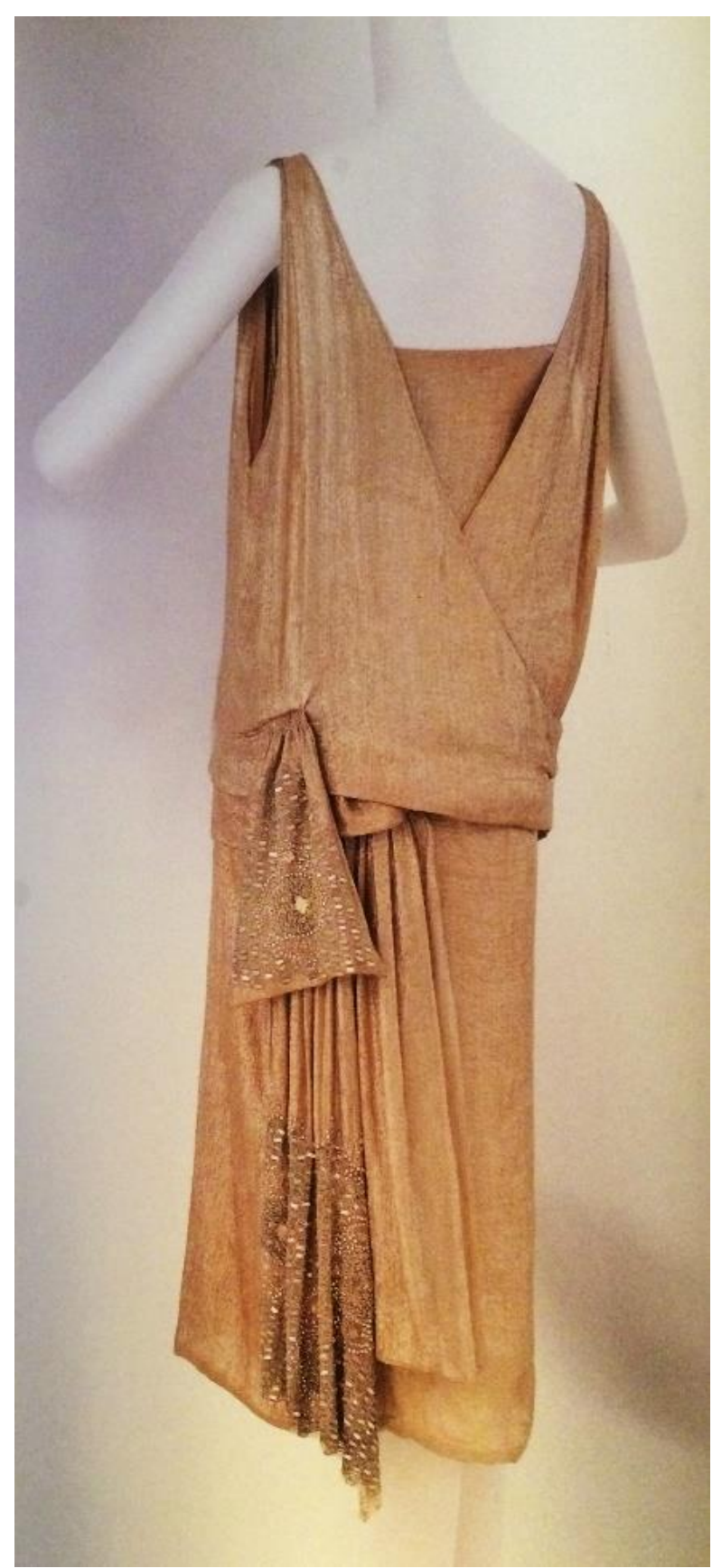

Fonte: Fukai, 2007, p. 366

Muitas das ornamentações que Vionnet utilizava eram resultado da manipulação do próprio tecido, de modo que possuíam ao mesmo tempo função decorativa e funcional. Em outras palavras, características estruturais tornam-se decorativas e vice-versa (FUKAI, 2007).

O vestido de seda (Figura 162) é um desses exemplos; não só assimila perfeitamente a construção e o corte retilíneo sem excessos, como também tem a ornamentação que reside nas discretas nervuras, as quais, à primeira vista, parecem simples, mas revelam construções 
complexas só existentes na alta-costura. De acordo com a mesma autora, o movimento das nervuras remete também ao jardim zen.

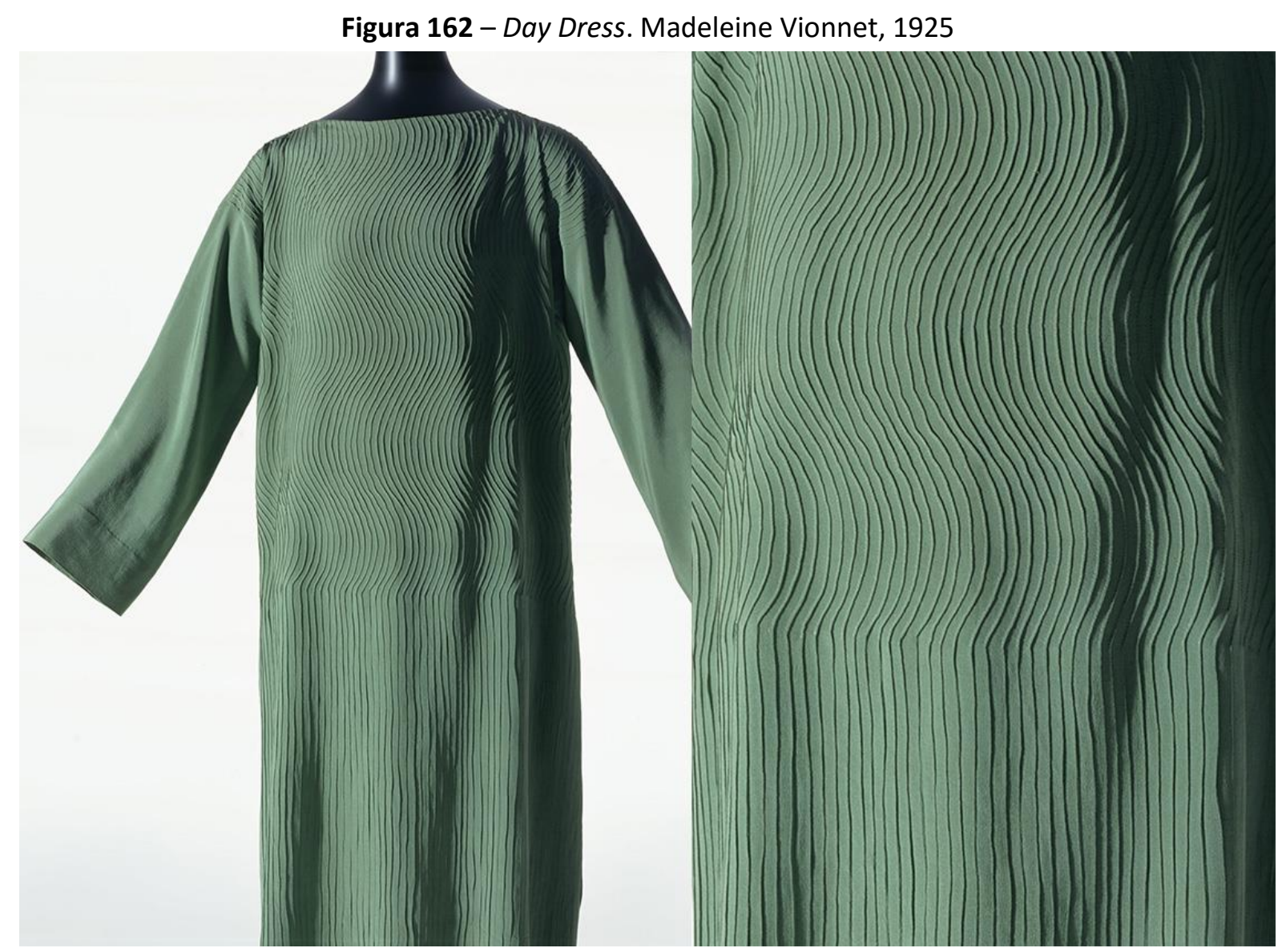

Fonte: http://www.kci.or.jp/archives/digital_archives/detail_138_e.html

Vionnet mostrou ser possível extrair o máximo do mínimo, o sofisticado do simples, de modo que se tornou uma das mais influentes designers de moda do século, pavimentando os princípios do vestuário do século XX.

Embora a presença de outras influências seja inegável no trabalho de Paul Poiret e Madeleine Vionnet, é certo afirmar que a moda refletiu as ideias revolucionárias da estética japonesa e dos movimentos artísticos, nos quais compartilhavam muitos preceitos, dando impulso a uma transição no vestir que utilizou muito mais que os aspectos de exotismo como fonte de inspiração. 


\section{CONSIDERAÇÕES FINAIS}

O fenômeno do Japonismo se configura como um relevante capítulo da história, e seu desenrolar confirma a hipótese anteriormente mencionada, de que o Japão influenciou o Ocidente de várias maneiras, direta e indiretamente. Com efeito, expôs de forma inédita, a maneira como o evento do intercâmbio cultural facilitou novos pontos de vista, novas concepções conceituais e visuais, não só catalisando no forjar de novos paradigmas, como também, auxiliando-os a se implantarem, de modo que, no dizer de Lambourne (2005), definiriam a arte e o design de moda moderno.

Martin e Koda (1994, p. 12) ressaltam que "A visão do Oriente alterou a vida e a moda ocidental". De fato, sua relevância nos impede de conceber a arte e a moda atual sem sua presença. O Japão ofereceu ao Ocidente, em um momento particularmente aberto a novas ideias, ofereceu uma janela para outra realidade; e por isso não é difícil compreender tamanho entusiasmo entre os ocidentais. O contato com o Japão renovou e revigorou os ânimos de forma singular; promoveu questionamentos acerca de convenções enraizadas e, por fim, auxiliou na concretização do novo, em um processo no qual redobrou-se a originalidade.

Apesar de o Japão ter se configurado como uma moda, como uma verdadeira mania na Europa, ele não é um estilo, nem a cópia do Japão. Como observado ao longo deste trabalho, existiram muitas realidades japonesas no imaginário ocidental, em sua maioria utópicas, que se traduziram e se desenrolaram em diversas vertentes, penetrando níveis superficiais e profundos. Foi por meio do olhar individual de cada artista e de cada designer, libertos de qualquer preconceito ou convencionalismo, que esse olhar se transformou criativamente, de modo a compor novas abordagens, novos impulsos criativos. Dessa forma, então, é possível alinhar a obra "A aula de Balé" de Edgar Degas ao vestido "Henriette" de Madeleine Vionnet, tão desvinculados à primeira vista, mas que se configuram no mesmo fenômeno, um legado do Japonismo.

A tabela abaixo resume e expõe de forma mais evidente as várias influências resultantes dessa fertilização cruzada abordadas nesse trabalho no capítulo 2 deste estudo: 


\begin{tabular}{|l|l|l|}
\hline \multicolumn{2}{|c|}{ ASPECTOS ABORDADOS } \\
\hline \multicolumn{1}{|c|}{ SUBITEM 3.2.1 } & \multicolumn{1}{|c|}{ SUBITEM 3.2.2 } & \multicolumn{1}{c|}{ SUBITEM 3.2.3 } \\
\hline Temática feminina & Bidimensionalidade & Paleta cromática intensa \\
Temas simples e cotidianos & Assimetria & $\begin{array}{l}\text { Múltiplos padrões } \\
\text { decorativos }\end{array}$ \\
$\begin{array}{l}\text { Séries com o mesmo tema } \\
\text { em diferentes estações ou } \\
\text { momentos do dia }\end{array}$ & $\begin{array}{l}\text { Relação figura e fundo } \\
\text { (espaços vazios) } \\
\text { Símbolo de autoria }\end{array}$ & $\begin{array}{l}\text { Bases verticalizadas } \\
\text { Figura truncada } \\
\text { Diagonalidade }\end{array}$ \\
\hline
\end{tabular}

Troca sempre gera prosperidade. E este estudo se propôs a expor esse desenvolvimento que, longe de limitar-se a um único meio, alastrou-se como se possuísse vida nos mais diversos campos, físicos e temporais em um sistema autogovernado impossível de se traçar fronteiras rígidas. A moda, é um processo não verbal que trabalha sempre atrelada ao seu tempo, e tem a mudança como uma das suas características inerentes. Assim sendo, deixou-se fatalmente influenciar pelo Japonismo de modo a se renovar de forma expressiva nos têxteis, no design e na construção. É certo admitir que esse fenômeno percebeu menor intensidade no âmbito do vestuário, se comparado ao mesmo período das manifestações artísticas. Porém, como visto, no virar do século XIX para o século $\mathrm{XX}$, os princípios diferenciados da estética nipônica, a destacar o reducionismo, aumentou o potencial do vestido asiático, que, consequentemente, auxiliou na concretização da reforma do vestuário ocidental, respaldando as novas e variadas necessidades do seu período.

A tabela abaixo evidencia as várias influências no âmbito da moda, de modo específico, no trabalho de Paul Poiret e Madeleine Vionnet: 


\begin{tabular}{|c|c|c|}
\hline \multicolumn{3}{|c|}{ ASPECTOS ABORDADOS NO CAPÍTULO 4} \\
\hline SUBITENS 4.1, 4.1.1, 4.1.2 & PAUL POIRET & MADELEINE VIONNET \\
\hline $\begin{array}{l}\text { Adaptação do uso do } \\
\text { quimono como roupão }\end{array}$ & $\begin{array}{l}\text { Ênfase depositada nos } \\
\text { ombros (casacos quimono) }\end{array}$ & $\begin{array}{l}\text { Vestidos e acessório com } \\
\text { referências no quimono e } \\
\text { no obi }\end{array}$ \\
\hline $\begin{array}{l}\text { Inserção e adaptação de } \\
\text { elementos decorativos } \\
\text { representativos nipônicos } \\
\text { (borboletas, flores, raios, } \\
\text { kabuto, etc) nos: }\end{array}$ & $\begin{array}{l}\text { Libertação do espartilho } \\
\text { Estrutura vertical exagerada }\end{array}$ & $\begin{array}{l}\text { Reducionismo } \\
\text { Roupas não restritivas }\end{array}$ \\
\hline $\begin{array}{l}\text { - Têxteis; } \\
\text { - Vestuário; } \\
\text { - Acessórios (bolsas, } \\
\text { sapatos, botões, guarda-sol } \\
\text { e leques) }\end{array}$ & $\begin{array}{l}\text { Paleta cromática intensa } \\
\text { Estampas chapadas e } \\
\text { gráficas }\end{array}$ & $\begin{array}{l}\text { Minimização do corte do } \\
\text { tecido e de costura } \\
\text { Moldes geométricos }\end{array}$ \\
\hline $\begin{array}{l}\text { Assimetria nos ornamentos } \\
\text { do vestuário }\end{array}$ & Abertura transpassada & Fluidez e movimento \\
\hline $\begin{array}{l}\text { Leques utilizados na } \\
\text { decoração e como } \\
\text { elemento de composição } \\
\text { para os artistas }\end{array}$ & $\begin{array}{l}\text { Decote estilo nukiemon } \\
\text { Pences e recortes } \\
\text { eliminados, silhueta } \\
\text { simplificada } \\
\text { Uso do leque como meio } \\
\text { publicitário }\end{array}$ & $\begin{array}{l}\text { Valorização e manipulação } \\
\text { do tecido } \\
\text { Inserção e adaptação de } \\
\text { elementos decorativos } \\
\text { representativos nipônicos } \\
\text { Tecido lamê }\end{array}$ \\
\hline
\end{tabular}

O Japão acomodou esse mundo de mudanças - e é por isso que conseguiu penetrar tão profundamente - e continua presente como ferramenta de frequente contribuição positiva, destacando o período globalizado em que vivemos. A recepção de uma influência nunca é passiva; por isso seus resultados são fecundos, porque não se trata da renúncia da própria cultura; trata-se, sim, da busca de respostas no outrem para nossos próprios 
questionamentos, de enxergar uma nova realidade com nossos próprios olhos, já acostumados com nossas concepções. É certo afirmar, portanto, que para que o Japonismo se desenvolvesse, foi fundamental que o Ocidente deixasse se influenciar: a contaminação cruzada depende de ambas as partes.

O quimono e os aspectos estéticos culturais do Japão; conceitos como o wabi-sabi, a beleza na imperfeição, o espaço $M a$, entre outros mencionados ao longo deste trabalho, emergem constantemente como suporte para inovar, diferenciar e revolucionar, mesmo que suas tradições primitivas não estejam tão vivas na sociedade. Na década de 1980, o neojaponismo, composto pelo trio de designers avant-garde japoneses Rei Kawabuko, Issey Mikaye e Yohji Yamamoto, altera dramaticamente o sistema da moda ao introduzirem novas estéticas e novas atitudes entre a relação corpo e vestuário, aos materiais e à estrutura, o que confirma o impacto do Japonismo desde o seu aparecimento. Diante de tudo que foi exposto, pode-se citar com propriedade o que Siegfried Wichmann (2007, p. 11) defendeu sobre o Japonismo "a sua influência foi e é multiforme, e pode ser vista operando em tantos níveis diferentes, que seu efeito ainda está longe de se esgotar". 


\section{REFERÊNCIAS BIBLIOGRÁFICAS}

ALEXANDER, Julia; HUTT, Helene. Ogi: A History of the Japanese Fan. Grã-Bretanha: Dauphin Publishing Limited, 1992.

ARGAN, Giulio Carlo. Arte Moderna: do lluminismo aos movimentos contemporâneos. Trad. Denise Bottmann e Federico Corotti. São Paulo: Companhia das Letras, 1992.

AQUINO, Rubim Santos Leão. História das Sociedades - das Sociedades Modernas às Sociedades Atuais. Rio de Janeiro: Imperial Novo Milênio, 2008.

BAKHTIN, Mikhail. Estética da Criação Verbal. São Paulo: Martins Fontes, 2003.

BAUDELAIRE, Charles. Poesia e Prosa. Rio de Janeiro: Ed. Nova Aguilar, 1995.

BEAUJOT Ariel. Victorian Fashion Accessories. Londres: Berg, 2012.

BENJAMIN, Walter. Passagens. Belo Horizonte: Editora da UFMG, 2009.

BOURDIEU, Pierre. O Poder Simbólico. Rio de Janeiro: Difel, 1989.

BREUER, Karin. Japanesque: The Japanese Print in the Era of Impressionism. San Francisco: Delmonico Books, 1994.

CHAMPIGNEULLE, Bernard. A Arte Nova. Cacém (Portugal): Gris Impressores, 1972.

CORDARO, Madalena Hashimoto. O sistema das artes do período Edo. In: Pinacoteca do Estado de São Paulo. O Florescer das Cores: A arte do período Edo. São Paulo: Agência de Cultura do Japão, 2008.

DEUTCH, Miriam; FLAM, Jack (Ed.). Primitivism and Twentieth-Century Art: A Documentary History California: University of California Press, 2003.

DOWNER, L. Madame Sadayakko: The Geisha who Seduced the West. London: Headline Books, 2013.

DRIESCH, Preethi von den. Body Image \& Dress-Designing: The Lives \& Works of Seven most Famous Fashion Designers of the World. [S.I.]: Preethi Sirimanne, 2014.

FAHR-BECKER, Gabriele. Grabados japoneses. Köln: Taschen, 1993.

FUKAl, Akiko. Fashion: A history from the 18th to the 20th Century. The Kyoto Costume Institute: Taschen, 2007.

Fashion: from the 18th to the 20th Century. Kyoto: Taschen, 2004.

GECZY, Adam; KARAMINAS, Vicki (Org.). Fashion and Art. Londres: Berg Publishers, 2013a. . Fashion and Orientalism: Dress, Textiles and Culture from the 17th Century to the 21st Century. Londres: Bloomsbury, 2013b.

GOMBRICH, Ernst. História da Arte. Rio de Janeiro: Editora Guanabara, 1993. 
The Image and the Eye. Further Studies in the Psychology of Pictorial Representation. London: Phaidon, 1982.

GOMPERTZ, Will. Isso é Arte? 150 Anos de Arte Moderna do Impressionismo até Hoje. Rio de Janeiro: Zahar, 2013.

GUTH, Christine. Art of Edo Japan: The Artist and the City 1615 - 1868. New Haven: Yale University Press, 1996.

Edo Art in Japan 1615 - 1868. Washington: National Gallery of Art, 1998.

. Japanese Art of the Edo Period. London: Calmann and King Ltd, 1996.

HAMILTON, J. A. Dress as a Cultural Sub-system: A Unifying Metatheory for Clothing and Textiles. Clothing and Textiles Research Journal, Vol. 1, 1987.

HAUSER, Arnold. The Social History of Art: Naturalism, Impressionism, The Film Age. New York: Routledge, 2005. $4 \mathrm{v}$.

HISAMATSU, Shin'ichi. Zen and the Fine Arts. California: Kodansha International Ltd., 1971.

IVES, Colta Feller. French Prints in the Era of Impressionism and Symbolism. New York: Metropolitan Museum of Art, 1998.

. The Great Wave: The Influence of Japanese Woodcuts on French Prints. New York: Metropolitan Museum of Art, 1979.

IVES, Colta; GIANBRUNI, Helen; NEWMAN, Sasha M. Pierre Bonnard: The Graphic Art. New York: Metropolitan Museum of Art, 1990.

KEYES, Roger S. Japanese Woodblock Prints: A Catalogue of the Mary Ainsworth Collection. Oberlin: Allen Memorial Art Museum, 1984.

KIRKE, Betty. Madeleine Vionnet. San Francisco: Chronicle Books, 2012

KLEINER, Fred S. Gardner's Art through the Ages. Book C: Non-Western Art to 1300. Boston: Cengage Learning, 2012.

KNOX, Kristine. Culture to Catwalk: How world cultures influence fashion. London: A \& C Black, 2011.

KODA, Harold; BOLTON, Andrew. Poiret. New York: Metropolitan Museum of Art, 2007.

KUVATOVA, V. Impressionism: The History, The Artists, The Masterpieces. Los Angeles: Prospekt LLC, 2012.

LAMBOURNE, Lionel. Japonisme: Cultural Crossings between Japan and the West. New York: Metropolitan Museum of Art, 2005.

LANE, Richard. Images from the Floating World. New York: Putnam Pub Group, 1978.

LINDSAY, Jack. Gustave Courbet his life and art. London: Adams and Dart, 1973. 
LIPOVESTSKY, G. O Império do Efêmero: A moda e seu destino nas sociedades modernas. São Paulo: Companhia das Letras, 2007.

MARTIN, Richard; KODA, Harold. Orientalism: Visions of the East in Western Dress. London: Phaidon, 2011.

MENG, Ji; ATSUKO, Ukai (Ed.). Translation, History and Arts. New Horizons in Asian Interdisciplinary Humanities Research. Cabridge: Cambridge University Press, 2013.

MILHAUPT, Terry Satsuki. Kimono: A Modern History. Londres: Reaktion Books, 2014.

MONTEIRO, Vagner. Fuga e representação do instante: um olhar oriental sobre as paisagens de inverno de Claude Monet e Camilo Pessanha. In: XI CONGRESSO INTERNACIONAL DA ABRALIC, 2008. São Paulo: USP, 2008.

NAKAGAWA, Hisayasu. Introdução à cultura japonesa: ensaio de antropologia recíproca. São Paulo: Martins Fontes, 2008.

OI, Célia. Tempo de Paz: o mundo japonês do período Edo. In: Pinacoteca do Estado de São Paulo. O Florescer das Cores: A arte do período Edo. São Paulo: Agência de Cultura do Japão, 2008.

OKAKURA, Kazuko. The Book of Tea. New York: Dover Publications, 2013.

OKANO, Michiko. Arte japonesa e suas supostas peculiaridades: espaços de onde se lança o olhar. In: XXXII COLÓQUIO CBHA, 2012, Brasília. Anais... Brasília: Universidade de Brasília, 2012. p. 1127-1149.

Fronteira e diálogo na arte japonesa. In: VI EHA - ENCONTRO DE HISTÓRIA DA ARTE, 2010. São Paulo: UNICAMP, 2010.

Ma - a estética do "entre". Revista USP, São Paulo, n. 100, p. 150 -164, 2014.

Japão e Ocidente: Mobilidade, Apropriação e Releitura. In: Anais do 22을 Encontro

Nacional de Pesquisadores em Artes Plásticas, 2013. Belém: ANPAP/PPGARTES/ICA/UFPA, 2013.

PINACOTECA do Estado de São Paulo. O Florescer das Cores: A arte do período Edo. São Paulo: Agência de Cultura do Japão, 2008.

ROYAL Academy of Arts. The Real Van Gogh: the artist and his letters. Catálogo da Exposição. Londres: The Royal Academy of Arts, 2010.

SANCHEZ, José Luis; ALMARZA, Meritxell. História da Arte. Do Neoclassicismo ao PósImpressionismo. Barcelona: Folio, 2008.

SANTOS, Alexandre Fontoura dos. A contribuição do confucionismo para as inter-relações doutrinárias presentes no pensamento japonês durante a formação do período Edo (séc. XVII). 2011. Dissertação (Mestrado em História) - Instituto de Filosofia e Ciências Humanas, Universidade Federal do Rio Grande do Sul, Porto Alegre, 2011. 
SAUNDERS, Rachel. Le Japon Artistique: Japanese Floral Pattern Design in the Art Nouveau Era. San Francisco: Chronicle Books LLC, 2010.

SEIJI, Nagata. Hokusai. Paris: Editions Prisma, 2014.

SERULLAZ, Maurice. O Impressionismo. Trad. Álvaro Cabral. Rio de Janeiro: Jorge Zahar, 1989. SCHAPIRO, Meyer. Impressionismo. Trad. Ana Luiza Dantas Borges. São Paulo: Cosac \& Naify, 2002.

SILVER, Kenneth E. Forbidden Fruits: The Perfumes of Rosine. In: KODA, Harold; BOLTON, Andrew. Poiret. New York: Metropolitan Museum of Art, 2007.

SIMON, Marie. Fashion in Art: The Second Empire and Impressionism. Paris: Editions Hazan, 1995.

SIMMONS, Pauline. Artists Designers of the Tokugawa Period. New York: Metropolitan Museum of Art Bulletin, 1958.

SLADE, Toby. Japanese Fashion: A Cultural History. New York: Bloomsbury Academic, 2009.

SMITH II, Henry D. Hokusai and the Blue Revolution in Edo Prints. Disponível em: <http://www.columbia.edu/ hds2/pdf/2005_Hokusai_and_the_Blue_Revolution.pdf >.

Acesso em: 06 fev. 2015

SOUZA, Gilda de Mello e. $O$ espírito das roupas: a moda no século XIX. São Paulo: Companhia das Letras, 1987.

SULLIVAN, Michael. The Meeting of Eastern and Western Art from the Sixteenth Century to the Present. London: Thames and Hudson, Ltd. 1973.

STRANGE, Edward F. Hokusai. The Old Man Mad with Painting. London, Siegle, Hill \& co., 1906. TCHERVIAKOV, Alexandre F. Fans: From the $18^{\text {th }}$ to the Beginning of the $20^{\text {th }}$ Century. Inglaterra: Parkstone Press, 1998.

TINTEROW, Gary; LOYRETTE, Henri. Origins of Impressionism. New York: Metropolitan Museum of Art, 1994.

TORTORA, Phyllis G.; EUBANK, Keith. Survey of Historic Costume. New York: Fairchild Pubns, 2005.

USPENSKY, Michael. Hiroshige. New York: Parkstone Press International, 2012.

UZANNE, Octave. The Fan. London: J.C. Nimmo and Bain, 1884.

VAN GOGH, Vincent. Cartas a Theo. Trad. Pierre Ruprecht. São Paulo: L\&PM Pocket, 2007.

V\&A - Victoria and Albert Museum. The Victorian Vision of China and Japan. Disponível em: < http://www.vam.ac.uk/content/articles/t/the-victorian-vision-of-china-and-japan>. Acesso em: 19 nov. 2014. 
V\&A. Corsets \& Crinolines in Victorian Fashion. Disponível em: < http://www.vam.ac.uk/content/articles/c/corsets-and-crinolines-in-victorian-fashion>. Acesso em: 09 dez. 2015.

WEISBERG, Gabriel P.; BECKER, Edwain.; POSSÉMÉ, Éveline. Les Origins de L’Art Nouveau. La Maison Bing. Paris: Musée des Arts Décoratifs, 2006.

WICHMANN, Siegfried. Japonisme: The Japanese Influence on Western Art since 1858. London: Thames \& Hudson, 2007.

WYE, Deborah. Artists \& Prints: Masterworks from the Museum of Modern Art. New York: The Museum of Modern Art, 2004.

XIMENES, Maria Alice. Moda e Arte na reinvenção do corpo feminino do século XIX. São Paulo: Estação das Letras e das Cores, 2009.

WILDENSTEIN, Daniel. Monet: or the triumph of Impressionism. Tradução de Chris Miller. Germany: Taschen, 1999.

\section{Webgrafia}

ART INSTITUTE of Chicago. Cassatt's Influence from Japanese Art, 2000. Disponível em: <http://www.artic.edu/aic/resources/resource/204>. Acesso em: 9 jan. 2015.

BELL, David. Explaining Ukiyo-e. Tese. (Doutorado em Filosofia) - University of Otago, Dunedin, Nova Zelândia, 2002. Disponível em: < https://ourarchive.otago.ac.nz/bitstream/handle/10523/598/BellDavid2004PhD.pdf?sequen ce=3 >. Acesso em: 15 jun. 2014.

BING, Siegfried. Le Japon Artistique: Documents d'Art et d'Industrie, 1888. Disponível em: <http://klibredb.lib.kanagawa-u.ac.jp/>. Acesso em: 19 jan. 2015.

CASPROWIAK, Katrina R. Fashioning the Woodcut: Raoul Dufy and the Avant-Garde. $117 \mathrm{f}$. Dissertação (Mestrado em Artes) - Art History and the Graduate School of the University of Oregon, Oregon, $2008 . \quad$ Disponível em: <https://scholarsbank.uoregon.edu/xmlui/bitstream/handle/1794/7479/thesis_MA_spring2 008_Casprowiak_Katrina_Rose.pdf?sequence=1> Acesso em 7 jan. 2016.

COLLEGE, Eckerd; GLIEM, David E. Japonisme and Bonnard's Invention of the Modern Poster. Japan Studies Association Journal, v. 6, p. 17-38, 2008. Disponível em: <http://www.phoebuspress.com/journals/index.php/jsaj/article/view/49/41>. Acesso em: 27 nov. 2014.

COOK, Alicia M. Edgar Degas's fan-shaped designs: Art, Decoration, and the Modern Woman in late-nineteenth-century France, 140 f. Dissertação (Mestrado em Artes) - University of 
Alabama and The University of Alabama at Birmingham, 2009. Disponível em: <https://www.mhsl.uab.edu/dt/2009m/cook.pdf>. Acesso em 9 out. 2015.

DEWIL, René. The Marriage of Joseph and Mary. 2007. Disponível em: <http://www.theartofpainting.be>. Acesso em 05 jan. 2015.

DOUMA, Michael. Van Gogh's Letters. Disponível em: <http://www.webexhibits.org/vangogh/about/credits.html. Acesso em: 3 fev. 2015.

ENCYCLOPAEDIA BRITANNICA. July Revolution. 2015a. Disponível em: <http://global.britannica.com/event>. Acesso em: 9 fev. 2016.

Genre Painting. 2015b. Disponível em: <http://global.britannica.com/art/genrepainting>. Acesso em: 10 fev. 2016.

ENGLISH, Bonnie. Japanese Fashion Designers: The work and influence of Issey Miyake, Yohji Yamamoto and Rei Kawakubo. London: Berg, 2011. Disponível em: < http://books.google.com.br/books/about/Japanese_Fashion_Designers.html?id=tzWz1v0riA QC\&redir_esc=y>. Acesso em: 8 abril 2014.

FLOWER, Henry. Fashion in Deformity. 1881. Disponível em: < https://archive.org/details/fashionindeform00flowgoog>. Acesso em 17 nov. 2015.

FREITAS, Artur. Apontamentos sobre a autonomia social da arte. Universidade Federal do Paraná, $2005 . \quad$ Disponível em: <http://www.ifch.unicamp.br/ojs/index.php/rhs/article/viewFile/166/158>. Acesso em: 15 ago. 2014.

FONSECA, Patrícia Helena Soares. A Schwestern Flöge: arte e moda na Viena de Klimt. Revista Belas $\quad 2010.2$ Disponível em: <http://www.belasartes.br/revistabelasartes/downloads/artigos/1/revista-ba-viena-deklimt.pdf>. Acesso em: 15 jan. 2016.

FUKAl, Akiko. Japonism in Fashion. New York: The Metropolitan Museum of Art, 1994. Disponível em:

http://www.kci.or.jp/research/dresstudy/pdf/e_Fukai_Japonism_in_Fashion.pdf>. Acesso em: 3 abril 2014.

GOMES, Ana Carolina; PICCOLO, Priscilla; REY, Ricardo. Exposições Universais: Sociedade no século XIX. NEC (Núcleos de Estudos Contemporâneos) - UFF. Niterói: UFF, 2011. Disponível em:

<http://www.historia.uff.br/nec/sites/default/files/Exposicoes_Universais_Sociedade_no_s eculo_XIX_0.pdf>. Acesso em: 20 out. 2014.

PEARCE, Robert. Louis-Philippe and the 1848 Revolutions. 2011. Disponível em: < http://www.historytoday.com>. Acesso em: 15 fev. 2016.

ISKIN, Ruth E. Modern Woman and Parisian Consumer Culture in Impressionism Painting, 2007. Disponível em: < http://academic.brooklyn.cuny.edu>. Acesso em: 17 jul. 2015. 
KATSUSHIKA Hokusai. Katsushika Hokusai: The Complete Works. Disponível em: < http://www.katsushikahokusai.org/>. Acesso em: 19 nov. 2014.

KIM, Laura; WILSON, Laurel E. The Influence of St. Louis 1904 World's Fair on Japonisme that Appeared in Periodicals. 2012. Dissertação (Mestrado em Ciências) - University of MissouriColumbia, Missouri, 2012. Disponível em: < https://mospace.umsystem.edu/xmlui/bitstream/handle/10355/15272/research.pdf?seque nce=2>. Acesso em: 20 jul. 2015.

LEAVENS, Ileana B. Van Gogh and Japonism. Indebtedness and Transformation. Education About Asia, v. 14, n. 2, p. 30-37, 2009. Disponível em: < http://www.asianstudies.org/EAA/EAA-Archives/14/2/842.pdf >. Acesso em: 18 nov. 2014.

LIMA, Ítalo Andrade. Fetiche e Mercadoria: Refleção de Walter Benjamin sobre as Exposições Internacionais. Universidade Estadual do Ceara, 2011. Disponível em: < http://www.gewebe.com.br/pdf/cad11/italo.pdf>. Acesso em: 27 nov. 2014.

McMANUS, Ian Christopher. Symmetry and asymmetry in aesthetics and the arts. Academia Europaea, 2005. Disponível em: <https://www.ucl.ac.uk/medical-education/reprints/2005EuropeanReview-Symmetry_Asymmetry.pdf>. Acesso em: 20 dez 2014.

MENON, Elizabeth K. The Functional Print in Commercial Culture: Henry Somm's Women in the Marketplace. Nineteenth-Century Art Worlwide, 2005. Disponível em: < http://www.19thc-artworldwide.org/summer05/61-summer05/summer05article/213-thefunctional-print-in-commercial-culture-henry-somms-women-in-the-marketplace>. Acesso em: 15 abril 2016

METROPOLITAN MUSEUM OF ART. The Kano School of Painting. In Heilbrunn Timeline of Art History. New York: The Metropolitan Museum of Art, 2003. Disponível em: <http://www.metmuseum.org/toah/hd/kano/hd_kano.htm>. Acesso em: 17 jul. 2014.

Evening Coat. In The Collection Online. New York: The Metropolitan Museum of Art. Disponível em: < http://www.metmuseum.org/collection/the-collectiononline/search/156074>. Acesso em: 12 dez. 2015.

MIKLOS, Claudio. A arte zen e o caminho do vazio: uma investigação sobre o conceito zen budista do Não-Eu na criação da arte. 2010. Dissertação (Mestrado em Ciência da Arte) Instituto de Arte e Comunicação, Universidade Federal Fluminense, Rio de Janeiro, 2010. Disponível em: <http://www.uff.br/cienciadaarte/dissertacoes/2010_claudio_miklos.pdf>. Acesso em: 20 set. 2014.

MoDA. The Museum of Domestic Design \& Architecture. London, Middlesex University. Disponível em: <http://www.moda.mdx.ac.uk/home>. Acesso: 20 set. 2014.

MORLEY, Christopher. Christopher Dresser, 2002. Disponível em: <http://www.christopherdresser.co.uk/>. Acesso em: 13 jul. 2015. 
MUSEUM of Fine Arts Boston. Conservation in Action: La Japonaise. 2013. Disponível em: < http://www.mfa.org/collections>. Acesso em: 27 out. 2014.

MARTIN, Richard; KODA, Harold. Waist Not: the migration of the waist. New York: The Metropolitan Museum of Art, 1994. Disponível em: < http://www.metmuseum.org/research/metpublications/Waist_Not_The_Migration_of_the_ Waist_1800_1960 >. Acesso em: 13 dez. 2015.

MURGUIA. Eduardo Ismael. Cenário Histórico do Movimento Impressionista. IMPULSO Revista de Ciências Sociais e Humanas, São Paulo, n. 24, p. 24-42, 1999. Disponível em: <http://www.unimep.br/phpg/editora/revistaspdf/imp24art02.pdf>. Acesso em: 18 out. 2014.

MUSEÉ d'ORSAY. Vincent van Gogh. Van Gogh's Bedroom in Arles, 2006. Disponível em: < http://www.musee-orsay.fr/en/collections/works-in

focus/search/commentaire/commentaire_id/la-chambre-de-van-gogh-a-arles-

16367.html?no_cache=1>. Acesso em: 19 set. 2014.

MUSÉE MULHOUSE. Le Musée de I'Impression sur Etoffes. Disponível em: < http://www.musee-impression.com/default.html>. Acesso em: 26 set. 2015.

NASH, Elizabeth. Edo Print Art and its Western Interpretations. Maryland: University of Maryland, 2004. Disponível em: <http://drum.lib.umd.edu/bitstream/1903/1891/1/umiumd-1865.pdf>. Acesso em: 17 abril 2014.

NEILL, James. Analysis of Professional Literature. 2006. Disponível em: < http://www.wilderdom.com/OEcourses/PROFLIT/Class6Qualitative1.htm\#Assumption >. Acesso em: 06 jun. 2014.

NIHON ICHIBAN. WASAGA “和傘” The Japanese Authentic Umbrella. Disponível em: HTTP://NIHON-ICHIBAN.COM/2012/09/14/WAGASA-\%E5\%92\%8C\%E5\%82\%98-THEJAPANESE-AUTHENTIC-UMBRELLA Acesso em nov. 2015.

NUNN, Joan. Fashion in Costume, 1200-2000. Chicago: New Amsterdam Books, 2000.

OGURO, Kazumi (Org.). An immersive exhibition of "re-created" works by Hokusai. 2013. Disponível em: <http://www.hokusaiexposed.com/>. Acesso em: 18 nov. 2014.

OSHINSKY, Sara J. Christopher Dresser (1834-1904). Heilbrunn Timeline of Art History. New York: The Metropolitan Museum of 2000-. http://www.metmuseum.org/toah/hd/cdrs/hd_cdrs.htm (October 2006)

PARKES, Graham. Japanese Aesthetics. California: The Stanford Encyclopedia of Philosophy, 2011. Edited by Edward N. Zalta. Disponível em: <http://plato.stanford.edu/archives/win2011/entries/japanese-aesthetics/>. Acesso em: 16 set. 2014.

PEZZOLO, Dinah Bueno. Moda e Arte: releitura no processo de criação. São Paulo: Editora Senac São Paulo, 2013. 
PIOCH, Nicolash. Hiroshige. Webmuseum Paris, 2002. Disponível em: < http://www.ibiblio.org/wm/paint/auth/hiroshige/>. Acesso em: 5 dez. 2014.

PIOTR, Spawski. Japonism in Polish Pictorical Arts (1885 - 1939). 2013. (Doctor of Philosophy Thesis) - University of the Arts London, at London, 2013. Disponível em: < http://ualresearchonline.arts.ac.uk/6205/>. Acesso em: 9 jan. 2015.

PUGLIESI, Vera. O Conceito de Cloisonnisme e sua utilização por Henri Matisse. Coletivo do Mestrado em Artes do Instituto de Artes/Unb - CoMA, 2004. Disponível em: http://www.geocities.ws/coma_arte/textos/verapugliese.pdf. Acesso em: 16 fev. 2015.

REYES, Alma. Looking East. From Boston to Tokyo. Japonisme in Retrospective. Wall Street International Art, 2014. Disponível em: <http://wsimag.com/art/11607-looking-east>. Acesso em: 9 nov. 2014.

RUGER, Axel (Coord.) Van Gogh the Letters. 2009. Disponível em: < http://www.vangoghletters.org/vg/>. Acesso em: 7 maio 2014.

SANTOS, Paulo César. Um Olhar sobre as Exposições Universais. In: XXVII SIMPÓSIO NACIONAL DE HISTÓRIA, 2013, Natal. Anais.... Disponível em: <http://www.snh2013.anpuh.org/resources/anais/27/1362520918_ARQUIVO_CesarANPUH 1.pdf>. Acesso em: 10 jan. 2015.

SAVORNIN, Sabine. Du Japonisme et de la peinture. Archives Ouvertes, 2008. Disponível em: $<$

https://hal.archivesouvertes.fr/file/index/docid/258081/filename/Japonisme_Choix_estheti ques_japonais_et_francais.pdf Acesso em: 18 nov. 2014.

THE FAN MUSEUM. History of Fans. Disponível em: < https://www.thefanmuseum.org.uk/fan-history>. Acesso em: 10 set. 2015.

THOMAS, Tony. Pierre Bonnard: the Intimiste. Disponível em:<http://www.escapeintolife.com/essays>. Acesso em: 18 set. 2014.

TIROCCHI, Anna; TIROCCHI, Laura. Fashion and Art. 2011. In: The Dressmakers Project, Brown University, Providence, Rhode Island, United States. Disponível em: <http://tirocchi.stg.brown.edu>. Acesso em: 19 fev. 2015.

WEINBERG, Barbara. Mary Stevenson Cassatt. New York: The Metropolitan Museum of Art. Disponível em: <http://www.metmuseum.org/toah/hd/cast/hd_cast.htm/>. Acesso em: 3 dez 2014.

WIENINGER, Johannes. Gustav Klimt and the Art of East Asia. 2012. Disponível em: <http://www.wieninger.com/assets/texte/Klimt\%20Wieninger.pdf>. Acesso em: 08 fev. 2015.

WILCOX, Matthew. Japanese erotic works and the world of Kitagawa Utamaro. Phaidon, 2010. 
<http://www.phaidon.com/agenda/art/articles/2010/october/14/japanese-erotic-worksand-the-world-of-kitagawa-utamaro/>. Acesso em: 8 dez. 2014.

WOLLEN, Peter. Fashion / Orientalism / The Body. London: Knowledge Matters, 1999. Disponível em:

http://www.amielandmelburn.org.uk/collections/newformations/01_05.pdf>. Acesso em: 15 abril 2014. 